UNIVERSIDADE DE SÃO PAULO

INSTITUTO DE GEOCIENCIAS

\title{
PROPOSTA DE REPRESENTAÇĀO CARTOGRÁFICA NA AVALIAÇÃO HIDROGEOLÓGICA PARA O ESTUDO DE PLANEJAMENTO E MEIO AMBIENTE, EXEMPLO DA REGIÃO METROPOLITANA DE CAMPINAS-SP
}

Sueli Yoshinaga Pereira

Orientadora: Profa. Dra. Annkarin Aurelia Kimmelmann e Silva

TESE DE DOUTORAMENTO

Programa de Pós-Graduação em Recursos Minerais e Hidrogeologia

SÃO PAULO

1996 


\title{
UNIVERSIDADE DE SÃO PAULO INSTITUTO DE GEOCIENNCIAS
}

\section{PROPOSTA DE: REPRESENTAÇÃO CARTOGRÁFICA NA AVALIAÇÃO PARA ESTUDO DE PLANEJAMENTO E MEIO AMBIENTE, EXEMPLO DA REGIÃO METROPOLITANA DE CAMPINAS - SP}

\author{
SUELI YOSHINAGA PEREIRA
}

Orientador: Prof ${ }^{\text {a. }}$ Dr $^{\text {a. }}$ Annkarin Aurelia Kimmelmann e Silva

\author{
TESE DE DOUTORAMENTO
}

\section{COMISSÃO JULGADORA}

Nome

Presidente: $\quad$ Prof $^{\mathrm{a}} \mathrm{Dr}^{\mathrm{a}}$ Annkarin Aurelia K. e Silva

Examinadores: Prof. Dr. Aldo da Cunha Rebouças

Dr. Hélio Nóbile Diniz

Prof. Dr. Heraldo Cavalheiro N.S. Campos

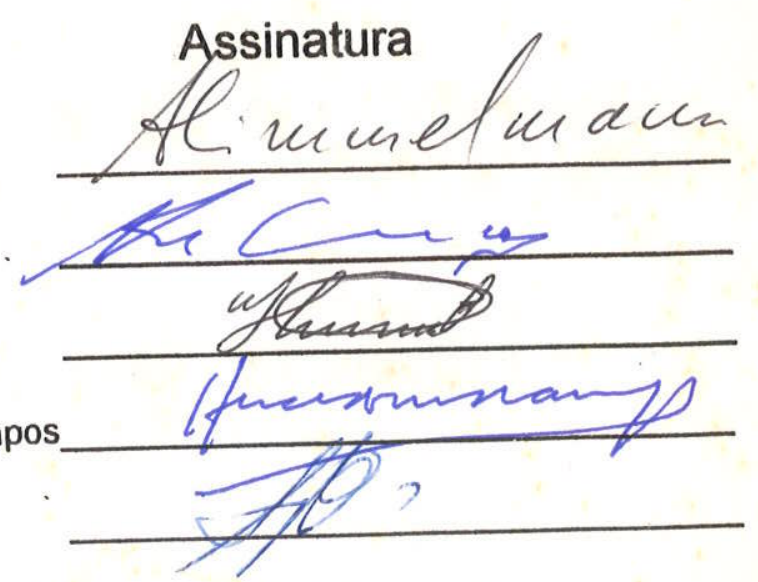




\section{UNIVERSIDADE DE SÃO PAULO \\ INSTITUTO DE GEOCIENCIAS}

\section{PROPOSTA DE REPRESENTAÇÃO CARTOGRÁFICA NA AVALIAÇĀO HIDROGEOLÓGICA PARA O ESTUDO DE PLANEJAMENTO E MEIO AMBIENTE, EXEMPLO DA REGIÃO METROPOLITANA DE CAMPINAS-SP}

Sueli Yoshinaga Pereira

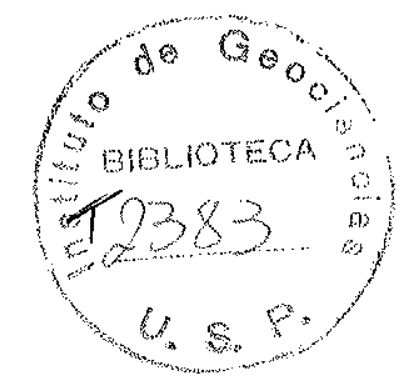

Orientadora: Profa. Dra. Annkarin Aurelia Kimmelmann e Silva

TESE DE DOUTORAMENTO

Programa de Pós-Graduação em Recursos Minerais e Hidrogeologia

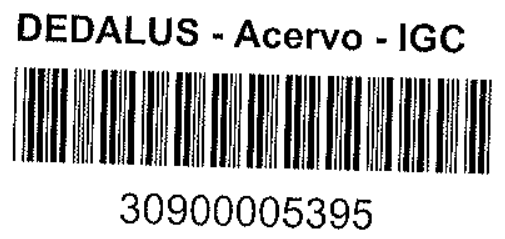

SÃO PAULO

1996 


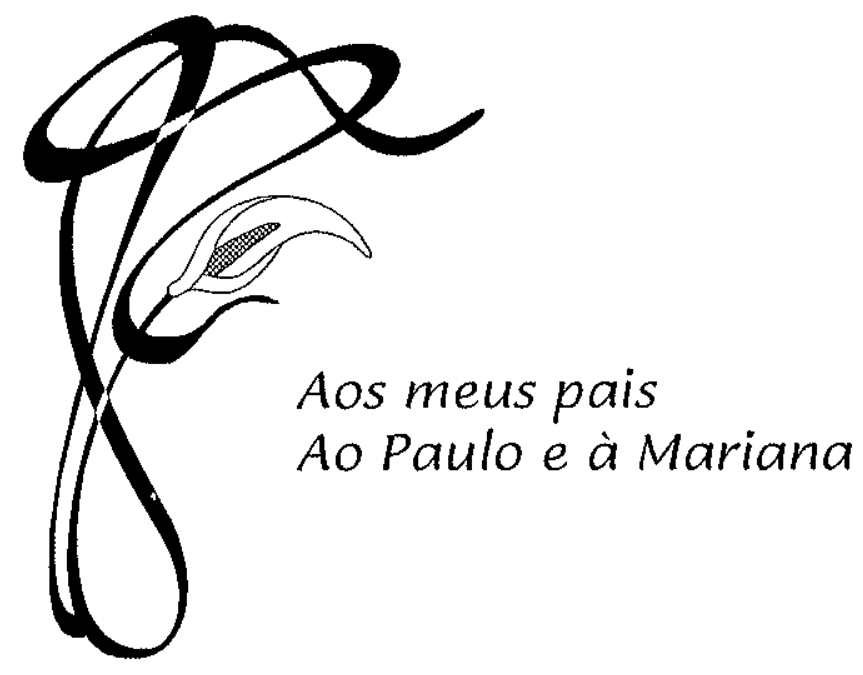




\section{AGRADECIMENTOS}

A realização deste trabalho tornou-se possível graças ao apoio e colaboração de pessoas e instituições, aos quais a autora deseja manifestar os mais sinceros agradecimentos.

Ao Instituto Geológico da Secretaria do Meio Ambiente do Estado de São Paulo, Ao Instituto de Geociências da Universidade de São Paulo,

Ao Departamento de Geologia Econômica e Geofísica Aplicada,

Ao Centro de Pesquisa de Águas Subterrâneas - CEPAS,

À orientadora, Profa. Dra. Annkarin Aurelia Kimmelmann e Silva,

Ao Prof. Dr. Uriel Duarte,

Ao Antonio Gonçalves Pires Neto,

Ao Geraldo Hideo Oda e Hélio Nóbili Diniz,

À Joveli dos Santos Leirião,

À Miriam Ramos Gutjahr,

À Sandra Moni de Souza,

Ao Renato Tavares e Vagner Vicente Denser Ferreira,

À Luciana Martin Rodrigues Ferreira, Seiju Hassuda, Mara Akie Iritani e Ricardo César Aoki Hirata,

Ao Paulo César Lima Padilha e Liana Maria Moretti,

Ao Otávio Coaracy Brasil Gandolfo,

Ao Marcos Aurélio Figueiredo Gomes, à Elisabete Souza Maia e Gabriela Lúcia da Costa e Castro,

A sra. Maria de Lourdes Figueiredo Gomes, sra. Maria Cristina Cardoso de Almeida e sr. Antonio de Oliveira Piedade, e

Ao Paulo Ricardo Brum Pereira. 


\section{ÍNDICE}

LISTA DE TABELAS ....................................................................................

LISTA DE FIGURAS..........................................................................................

LISTA DE ANEXOS.................................................................................iii

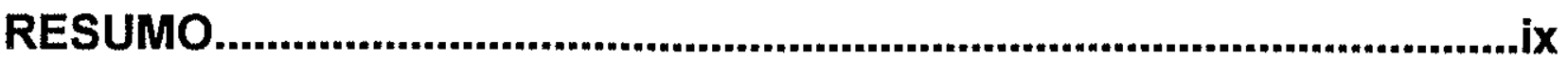

ABSTRACT

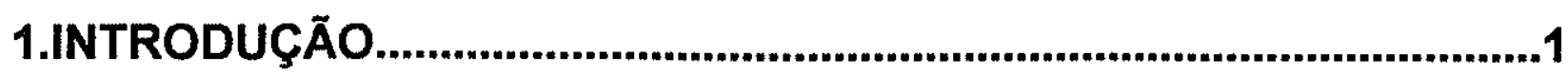

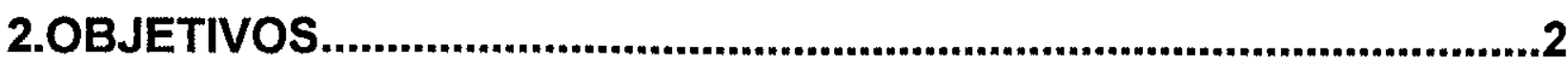

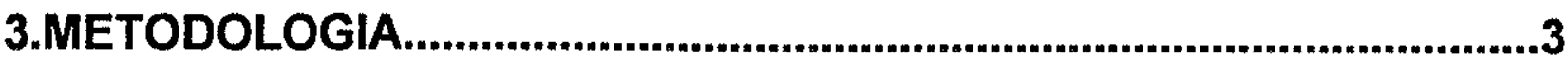

3.1.ANÁLISE DAS METODOLOGIAS EXISTENTES........................................3

3.1.1.Estudos de Avaliação e Cartografia Hidrogeológica..................3

3.1.2. Estudos do Meio físico com enfoque ao

Planejamento e Análise Ambiental.....................................................18

3.2.MÉTODO APLICADO........................................................................35

3.2.1.Procedimentos de aquisição, armazenamento e

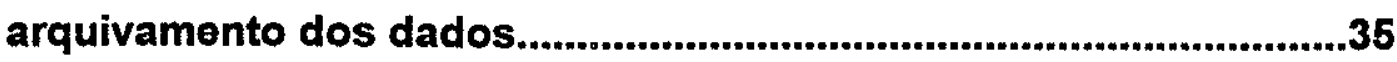

3.2.2.Processamento $\theta$ Análise das Informações.................................36

4.REGIÃO METROPOLITANA DE CAMPINAS.....................................47

4.1.LOCALIZAÇÃO GEOGRÁFICA ...............................................................47

4.2.EVOLUÇÃO SÓCIO-ECONÓMICA............................................................49

4.3.CARACTERIZAÇÃO DO MEIO FISICO .................................................55

4.4.1.Goologia.....................................................................................55

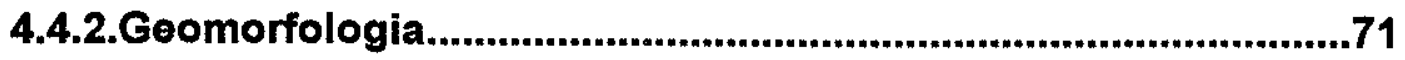

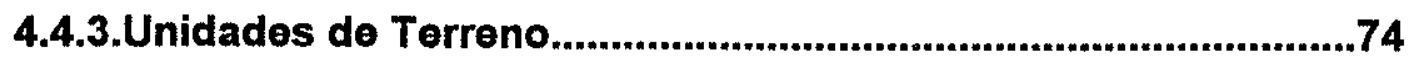

4.4.CLIMA

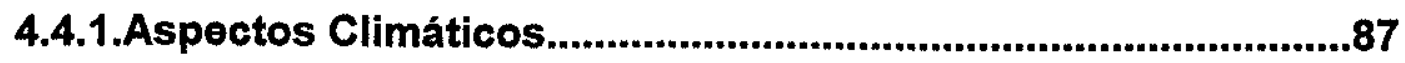


4.4.2. Balanço Hídrico.

4.4.3.As Unidades Climáticas

5.ÁGUA SUBTERRÂNEA

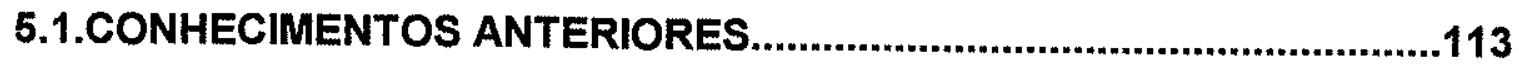

5.2.CONDIÇÕES DE OCORRÊNCIA...........................................................119

5.2.1.Geometria dos Sistemas Aquiferos....................................119

5.2.1.1. Sistema Aqüifero Cristalino................................................119

5.2.1.2. Sistema Aqüifero Tubarão: Aqüifero Itararé...........................125

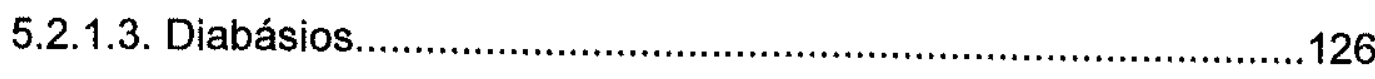

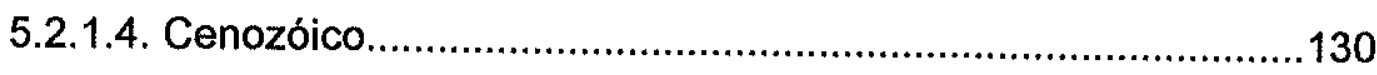

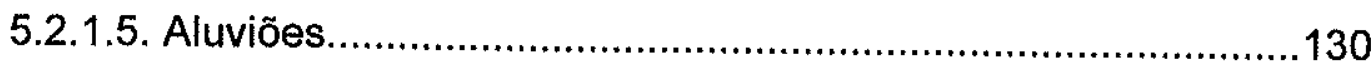

5.2.2.Circulação das Águas Subterrâneas - Condições

de Recarga e Descarga Locais......................................................131

5.2.3.Caracterização Hidrodinâmica.................................................133

5.3.DISPONIBILIDADE E CONSUMO DO RECURSO

HÍDRICO SUBTERRÂNEO...................................................................160

6.PLANEJAMENTO E MEIO AMBIENTE..............................................165

6.1.DEFINIÇÃO DAS UNIDADES HIDROGEOLÓGICAS ..............................167

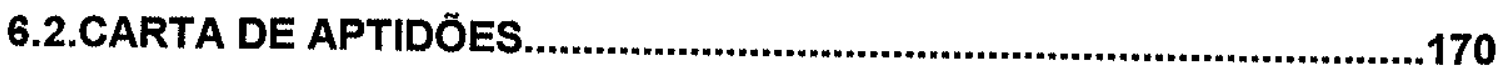

6.2.1.PRODUTIVIDADE................................................................170

6.2.2.VULNERABILIDADE NATURAL............................................171

6.3.CARTA ORIENTATIVA AO USUÁRIO DAS ÁGUAS

SUBTERRÂNEAS.

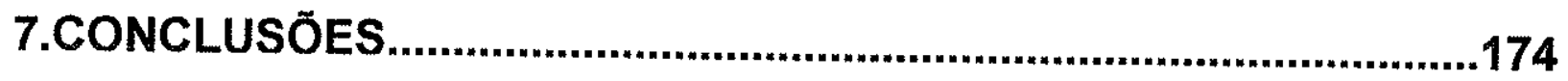

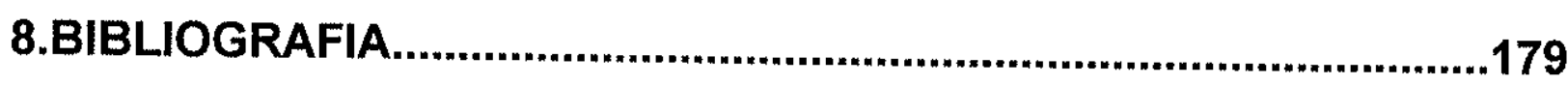




\section{LISTA DE TABELAS}

Tabela 1 - Representação gráfica de hidrogeologia em relação ao nível de informação e uso possivel (Struckmeyer \& Krampe 1992).

Tabela 2 - As classes de terreno da metodologia P.U.C.E. (modificado de Zuquette \& Gandolfi 1988)

Tabela 3 - Postos pluviométricos utilizados no estudo

Tabela 4 - Estimativa do uso de poços tubulares profundos por atividade econômica na Região Metropolitana de Campinas

Tabela 5 - Data de criação e origem dos municipios da Região Metropolitana de Campinas.

Tabela 6 - Evolução demográfica dos municipios da Região Metropolitana de Campinas no periodo de 1960 - 1991 (EMPLASA 1993).

Tabela 7 - Domínios e atitudes principais da foliação gnáissica do Complexo Itapira no município de Campinas (baseado em IG 1993)

Tabela 8 - Principais estruturas rúpteis da regiäo norte do município de Campinas (IG 1995)

Tabela 9 - Sintese da evolução geológica da Região Metropolitana de Campinas (modificado de IG 1995).

Tabela 10 - Caracterização das Unidades de Terreno e suas associações

com o relevo, substrato rochoso, solos e drenagens $80,81,82.83,84,85,86$

Tabela 11 - Legenda do mapa de unidades climáticas

Tabela 12 - Síntese da bibliografia existente sobre a hidrogeologia regional...117,118

Tabela 13 - Valores de mediana e média de capacidade específica e vazão de poços localizados no Sistema Aqüífero Cristalino.

Tabela 14- Valores de transmissividades calculadas em poços do Sistema Aqüifero Cristalino.

Tabela 15 - Valores de mediana e média de capacidade especifica $e$ vazão de poços localizados em lineamentos de drenagem no Sistema Aqüifero Cristalino

Tabela 16 - Valores de mediana e média de capacidade específica e vazão de poços localizados fora de lineamentos de drenagem no Sistema Aqüifero Cristalino

Tabela 17 - Valores de mediana e média de capacidade específica e vazão de poços localizados no Sistema Aqüifero Tubarão - Aqüífero Itararé.....

Tabela 18 - Valores de mediana e média de capacidade específica e vazão de poços localizados em lineamentos de drenagem no Sistema Aqüifero Tubarão - Aqüifero Itararé.

Tabela 19 - Valores de mediana e média de capacidade específica e vazão de poços localizados fora de lineamentos de drenagem no Sistema Aqüífero Tubarão - Aqüífero Itararé. 
Tabela 20 - Valores de mediana e média de espessuras de arenito em relação a capacidade especifica no Sistema Aqüífero Tubarão Aqüífero Itararé

Tabela 21 - Valores de mediana e média de capacidade específica e vazão de poços que exploram o Diabásio.

Tabela 22 - Valores de mediana e média de capacidade específica e vazão de poços que exploram o Diabásio localizados em lineamentos de drenagem

Tabela 23 - Valores de mediana e média de capacidade especifica e vazão de poços que exploram o Diabásio localizados fora de lineamentos de drenagem

Tabela 24 - Valores de mediana e média de capacidade específica e vazão de poçosque exploram mais de um aqüifero

Tabela 25 - Valores de mediana e média de capacidade especifica e vazão de poços que exploram mais de um aqüífero em lineamentos de drenagem

Tabela 26 - Valores de mediana e média de capacidade específica e vazão de poços que exploram mais de um aqüifero localizados fora de lineamentos de drenagem

Tabela 27 - Valores de mediana e média de capacidade específica e vazão de poços mistos, e de poços por tipo de sistema aqüifero explorado.

Tabela 28 - Valores de transmissividades calculadas em poços do Sistema Aqüifero Tubarão e Cristalino

Tabela 29 - Estimativa da disponibilidade da água subterrânea dos sistemas aqüíferos por meio de dados de escoamento básico de rios principais por sub-bacias na Região Metropolitana de Campinas (baseado em Lopes 1994)

Tabela 30 - Disponibilidade natural de água subterrânea por sistema aqüífero na Regiäo Metropolitana de Campinas

Tabela 31 -Estimativa de exploração de água subterrânea nos sistemas aqüíferos da Região Metropolitana de Campinas

Tabela 32 - Classificação da vulnerabilidade natural dos Sistemas Aqüiferos na Região Metropolitana de Campinas - SP 


\section{LISTA DE FIGURAS}

Figura 1 - Mapa de localização e de vias de acesso da Região Metropolitana de Campinas - SP (modificado de EMPLASA 1993)

Figura 2 - Mapa de domínios estruturais de foliação acompanhado de

estereogramas de projeção polar e de contagem (IG 1993).

Figura 3 - Orientação dos lineamentos por domínio (IG 1995).

Figura 4 - A situação dos blocos estruturais na região (Pires Neto 1996).

Figura 5 - Mapa Bouguer do Estado de São Paulo (IPT 1989).

Figura 6 - Mapa Geomorfológico na Região Metropolitana de Campinas

(Pires Neto 1996).

Figura 7 - Mapa de Unidades de Terreno na Região Metropolitana de Campinas...79

Figura 8 - Pluviometria média anual do periodo $(1976$ - 1991) ..........................89

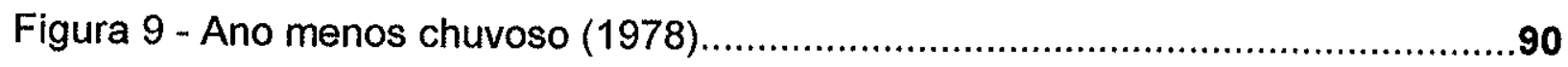

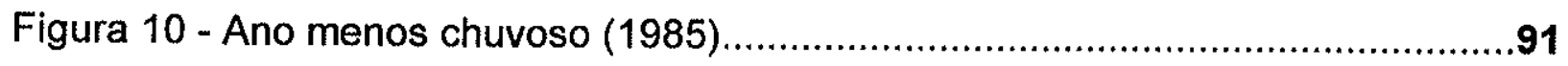

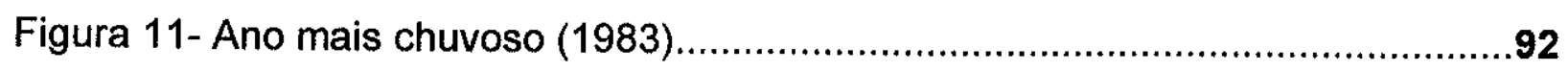

Figura 12 - Trimestre mais chuvoso: janeiro, fevereiro e março.............................94

Figura 13 - Trimestre menos chuvoso: junho, julho e agosto..................................95

Figura 14 - Variação mensal da precipitação pluviométrica $(\mathrm{mm})$ no transecto Arcadas - Capivari - período 1976 - 1991.

Figura 15 - Variação mensal da precipitação pluviométrica (mm) no transecto Arcadas - Capivari - ano menos chuvoso (1978)

Figura 16 - Variação mensal da precipitação pluviométrica $(\mathrm{mm})$ no transecto

Arcadas - Capivari - ano menos chuvoso (1985).

Figura 17 - Variação mensal da precipitação pluviométrica $(\mathrm{mm})$ no transecto Arcadas - Capivari - ano mais chuvoso (1983)

Figura 18 - Evapotranspiração potencial.

Figura 19 - Excedente hidrico.

Figura 20 - Variação mensal da evapotranspiração potencial ( $\mathrm{mm}$ ) no transecto Arcadas - Capivari - período 1976 - 1991.

Figura 21 - Variação mensal do excedente hídrico $(\mathrm{mm})$ no transecto Arcadas Capivari - periodo 1976 - 1991.

Figura 22 - Variação mensal da deficiência hídrica $(\mathrm{mm})$ no transecto Arcadas Capivari - período 1976 - 1991

Figura 23 - Representação das feições climáticas individualizadas dentro das células climáticas regionais e das articulações destas nas faixas zonais

(modificado de Monteiro 1973).

Figura 24 - Mapa Sintese das Unidades Climáticas. 
Figura 25 - Mapa de contorno estrutural do embasamento cristalino

Figura 26 - A situação dos blocos estruturais na Região Metropolitana de
Campinas

Figura 27 - Distribuição do manto de alteração no embasamento cristalino na

Região Metropolitana de Campinas

Figura 28 - Área de ocorrência de arenitos (em \%) em subsuperfície na Região

Metropolitana de Campinas

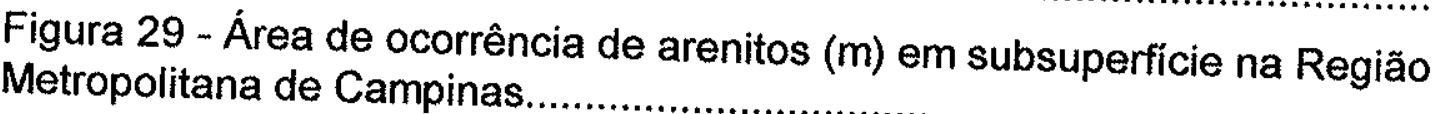

Figura 30 - Área de ocorrência de diabásios em superfície e subsuperfície na

Região Metropolitana de Campinas

Figura 31 - Mapa de distribuição das linhas equipotenciais Região

Metropolitana de Campinas

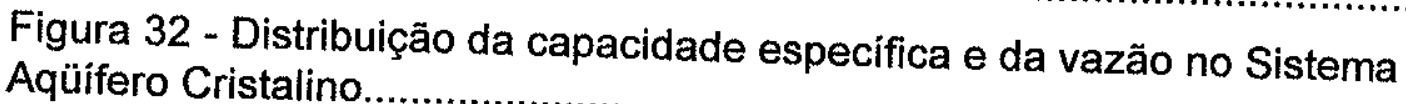

Figura 33 - Distribuição da capacidade específica e da vazão em poços

localizados em lineamentos de drenagem no Sistema Aqüífero Cristalino

Figura 34 - Distribuição da capacidade especifica e da vazão em poços

localizados fora de lineamentos de drenagem no Sistema Aqüifero Cristalino

Figura 35 - Distribuição da capacidade específica e da vazão no Sistema Aqüífero Tubarão - Aqüífero Itararé

Figura 36 - Distribuição da capacidade especifica e da vazão em poços

localizados em lineamentos de drenagem no Sistema Aqüífero Tubarão -

Figura 37 - Distribuição da capacidade específica e da vazão em poços

localizados fora de lineamentos de drenagem no Sistema Aqüífero Tubarão -
Aqüífero Itararé..........................

Figura 38 - Distribuição da capacidade específica em função da maior

porcentagem da espessura de arenitos no Sistema Aqüifero Tubarão -

Figura 39 - Distribuição da capacidade especifica e da vazão de poços
localizados em diabásios.

Figura 40 - Distribuição da capacidade especifica e da vazão em poços

localizados em lineamentos de drenagem em diabásios

Figura 41 - Distribuição da capacidade específica e da vazão em poços

localizados fora de lineamentos de drenagem nos diabásios

Figura 42 - Distribuição da capacidade específica e da vazão de poços mistos

Figura 43 - Distribuição da capacidade específica e da vazão em poços mistos localizados em lineamentos de drenagem.

Figura 44 - Distribuição da capacidade específica e da vazão em poços mistos localizados fora de lineamentos de drenagem. 
Figura 45 - Distribuição espacial da produtividade no Sistema Aqüifero Cristalino.

Figura 46 - Distribuição espacial da produtividade no Sistema Aqüifero

Tubarão - Aqüífero ltararé

Figura 47 - Distribuição espacial da produtividade em poços locados em diabásios

Figura 48 - Distribuição espacial da produtividade dos poços mistos. 158

Figura 49 - Consumo da água subterrânea por município na Região Metropolitana de Campinas. 


\section{ANEXOS}

Anexo 1 - Cadastro dos poços tubulares profundos

Anexo 2 - Mapa geológico da área de estudo

Anexo 3 - Carta das Unidades Hidrogeológicas

Anexo 4 - Carta de Produtividade

Anexo 5 - Carta de Vulnerabilidade Natural dos Aqüiferos

Anexo 6 - Carta Orientativa ao Usuário das Águas Subterrâneas 


\section{RESUMO}

O presente trabalho apresenta o desenvolvimento de dois temas distintos na Região Metropolitana de Campinas, Estado de São Paulo.

O primeiro tema trata-se do aprofundamento do conhecimento hidrogeológico dos Sistemas Aqüíferos Tubarão e Cristalino e das condições de ocorrência da água subterrânea em corpos de diabásio e de depósitos cenozóicos. O segundo tema desenvolvido é relativo aos estudos de planejamento e meio ambiente, onde a hidrogeologia fornece subsídios aos estudos do meio físico.

O Sistema Aqüifero Cristalino é composto pelas rochas do Complexo Itapira, Granitos Morungaba e itu e Granitóide Jaguariúna; está localizado à leste da área, apresentando um valor mediano de capacidade específica de $0,1 \mathrm{~m}^{3} / \mathrm{h}$ por metro de rebaixamento e transmissividades de 0,13 a $6,85 \mathrm{~m}^{2} /$ dia. A maior produtividade dos poços está vinculada à ocorrência de fissuras das rochas causadas pelas grandes estruturaçōes existentes (as zonas de cisalhamento Campinas e Valinhos, falhas normais e transcorrentes, e fraturamentos associados).

O Sistema Aqüifero Tubarão - Aqüifero Itararé, está aflorante na sua porção central e oeste, e apresenta $0,11 \mathrm{~m}^{3} / \mathrm{h}$ por metro de rebaixamento de capacidade especifica. A ocorrência de sedimentos arenosos em subsuperficie é responsável pela maior produtividade dos poços, juntamente com a existência de maior espessura do pacote sedimentar e estruturações da rocha.

Nos poços mistos, a maior produtividade é encontrada na combinação dos sistemas aqüiferos Itararé/Diabásio; em geral, apresenta a mediana de capacidade específica de 0,07 $\mathrm{m}^{3} / \mathrm{h}$ por metro de rebaixamento, e tendências bem distintas. As áreas de menor potencial se encontram próximos ao contato do embasamento cristalino e as de maior potencial, em faixas de direção NE, ao longo da região de estudo.

A produtividade dos poços na Região Metropolitana de Campinas está relacionada também às movimentações neotectônicas dos blocos estruturais definidos na área. A tendência de maior produtividade dos poços nos locais de caimento dos blocos estruturais é notória.

A maior intensidade de exploração dos poços está vinculada diretamente com o tipo de atividade econômica da região, seu grau de desenvolvimento e da relação reserva/demanda de água atual. A utilização desse recurso hidrico é realizada pelas indústrias no eixo Valinhos - Campinas - Piracicaba, representada pela trajetória da rodovia Anhanguera, enquanto que na porção leste e nordeste, o consumo da água subterrânea é feita pela atividade agropecuária e extrativista (mineração).

O município de Campinas é o maior consumidor do recurso hídrico subterrâneo, seguido em menores proporções os municipios de Valinhos, Paulínia, Nova Odessa e Americana.

A estimativa da reserva ativa em relação ao consumo revela um alto indice de exploração: cerca de $79 \%$ da reserva natural ou $54 \%$ da reserva total são exploradas na Região Metropolitana de Campinas, com uma maior taxa de aproveitamento para o Aqüifero Itararé, seguido do Cristalino.

A Carta de Unidades Hidrogeológicas é a carta sintese das condições de ocorrência das águas subterrâneas, elaborada através da integração das informações do meio físico.

Os mapas de produtividade e de vulnerabilidade natural dos aqüiferos são as cartas interpretativas visando apresentar uma aptidão do meio físico da área de estudo quanto a esses temas; a Carta Orientativa ao Usuário do Recurso Hídrico Subterrâneo é a síntese das demais cartas expostas acima, contendo as recomendações ou critérios para uma exploração racional do recurso. 


\section{ABSTRACT}

In the present work two themes are developed in the Metropolitan Region of Campinas, São Paulo State, Brazil. While one deals with the enhancement of the hydrogeological knowledge of Tubarão and Crystalline Aquifers Systems and the occurrence of groundwater in diabase and cenozoic sediments, the other is related to environmental planning studies being subsidized by hydrogeological research.

On the east of the area the Crystalline Aquifer System presents $0,1 \mathrm{~m}^{3} / \mathrm{h} / \mathrm{m}$ of average specific capacity and 0,13 to $6,85 \mathrm{~m}^{2} /$ day of transmissivity. The higher productivity is linked to the occurrence of rock fissures and fault zones.

The Tubarão Aquifer System emerges on the Central and western areas and presents $0,11 \mathrm{~m}^{3} / \mathrm{h} / \mathrm{m}$ in specific capacity. The higher productivity is linked to the occurrrence of sand sediments on subsurface and also by the thickness of the sedimentary pack and rock structural complexity.

The lower potencial areas are localized near the cristallyne rock contact and the higher potential ones in bands directed NE, along the study area.

The high exploitation of the water resource in the area is explained by the type of industrial activity, its degree of economical development and the present relation between demand and reserves.

The Map of Hydrogeological Unities is the synthesis of occurrence conditions of groundwater, organized through the integration of environmental informations. 


\section{INTRODUÇÃO}

A importância da água subterrânea como recurso disponivel no estado, para o abastecimento em áreas industriais, agriculturáreis e urbanas, é crescente e cada vez mais conhecida.

A escassez de água superficial motivada pela falta de qualidade e quantidade do recurso e pela falta de investimento em saneamento básico pelo estado são as causas do aumento indiscriminado do uso deste recurso. A exploração da água subterrânea muitas vezes ocorre de forma irracional e impactante, pois não há aplicação efetiva da legislação existente sobre as águas subterrâneas e tampouco uma politica contínua para otimizar o uso dos recursos hídricos.

É cada vez mais necessária a avaliação hidrogeológica para o melhor conhecimento da ocorrência natural das águas subterrâneas, sua potencialidade e exploração como recurso natural, vulnerabilidade e impactos ocorrentes no meio ambiente, para que este recurso estratégico seja protegido e seu uso, racionalizado.

O presente trabalho consiste, primeiramente, na execução de uma avaliação hidrogeológica, executada na Região Metropolitana de Campinas, pertencente à área de conurbação da Bacia do Piracicaba e Capivari, onde ocorrem dois sistemas aqüiferos regionais: o Cristalino e o Tubarão, e subordinadamente, os diabásios.

Nessa área, o trabalho pretende ampliar o conhecimento desses sistemas aqüiferos e suas inter-relações, apresentando também a situação das condições de exploração e uso do recurso hídrico subterrâneo. O crescente agravamento da qualidade e quantidade dos recursos hídricos (superficiais e subterrâneos), decorrente da intensa metropolização e de seu uso indiscriminado é conhecido e preocupante ao público e aos organismos de decisão.

A água subterrânea é um parâmetro a ser considerado como um fator de influência para a implantação de obras de engenharia, como um recurso natural disponivel e como um importante atributo do meio ambiente a ser protegido.

Face a isso, este trabalho visa também desenvolver procedimentos de avaliação e cartografia hidrogeológica para subsidiar os estudos do meio físico, estabele- 
cendo uma metodologia para aplicação dos estudos hidrogeológicos para fins de planejamento de uso e ocupação do solo.

\section{OBJETIVOS}

O presente trabalho estabelece os seguintes objetivos:

- Aprofundar o conhecimento hidrogeológico na área investigada, especificamente nos Sistemas Aqüíferos Tubarão (Aqüífero Itararé), Cristalino e subordinadamente o Diabásio, na Região Metropolitana de Campinas, área de franco desenvolvimento sócio-econômico e extremamente carente de recursos hídricos em qualidade e quantidade.

- Elaborar cartas temáticas dos estudos hidrogeológicos para aplicação ao planejamento de uso e ocupação do solo e análise ambiental. A integração dos diversos temas desenvolvidos da hidrogeologia através de uma carta síntese, produzirá estratégias e diretrizes para uso e preservação do recurso ou do atributo.

- Fornecer um diagnóstico e principalmente um prognóstico, "traduzindo" e respondendo diretamente as informações ao usuário (político, administrador ou técnico de de outras áreas). 


\section{METODOLOGIA}

\subsection{ANÁLISE DAS METODOLOGIAS EXISTENTES}

\subsubsection{Estudos de Avaliação e Cartografia Hidrogeológica}

Os estudos de avaliação hidrogeológica e a cartografia são assuntos intima- mente relacionados, uma vez que esta última é a representação espacial da síntese dos conhecimentos. Os estudos hidrogeológicos e da cartografia encontradas na literatura científica, é analisada pelos seguintes prismas: através do processo evolutivo do conhecimento, e da função dos diversos tipos de estudos de hidrogeologia.

Os estudos hidrogeológicos vem se modificando, juntamente com a própria visão da função do hidrogeólogo e do avanço dos métodos e das técnicas de estudos.

Em termos da cartografia hidrogeológica, uma idéia da evolução e de seu papel é avaliada por Collin (1991), que identificou três momentos (ou estados) do desenvolvimento da cartografia hidrogeológica, que por sua vez retratam o estado evolutivo dos estudos de hidrogeologia.

No primeiro estado, a cartografia representa um documento elaborado como um relatório, as informações hidrogeológicas eram sobretudo pontuais e as espacializaçöes se restringiam a carta geológica, frequentemente traduzidos em termos de litologia.

No segundo momento, a cartografia é elaborada por hidrogeólogos especializados e há uma certa padronização nos mapas; no entanto, essa cartografia é por demais analítica e pouco "dinâmica'. A caracterização das condições de recarga e transmissividades introduz um início da idéia de modelização nos estudos hidrogeológicos.

O terceiro momento identificado é a transmissão do conhecimento ao público, feita por meio das cartas temáticas, que são executadas de duas maneiras: por superposição gráfica (adição ou subtração de uma imagem à outra, produzindo uma terceira família de contornos), ou por associação preliminar de parâmetros numéricos 
diversos e constituição de index, que são objetos de procedimentos de interpolação. O contorno geológico permite definir as "regiōes presumivelmente homogêneas".

Um outro enfoque de análise desses estudos baseiam-se na existência de variados tipos de estudos hidrogeológicos, que é influenciada por diversos fatores técnicos e operacionais, como: estado da arte do conhecimento, objetivos do projeto, vo- lume e qualidade de informação dos dados disponiveis, escala de estudo, mão de obra, experiência do profissional hidrogeólogo, custo e tempo. Em vista disso, os mapas hidrogeológicos são bastante diversificados.

Assim, em primeiro momento, pode-se identificar dois ramos de estudos hidrogeológicos. O primeiro consiste do estudos de avaliações hidrogeológicas e dos levantamentos de caráter regional e sistemático executados por órgãos de governo estaduais ou federais (como departamentos ou serviços geológicos), com o intuito de fornecer sobretudo informações sobre o comportamento hidrodinâmico e estrutural dos sistemas aqüíferos, a potencialidade e qualidade do recurso hídrico subterrâneo.

Em termos de cartografia, Struckmeier \& Krampe (1992) classificam os mapas resultantes desse tipo de estudo como os mapas gerais e sistemáticos, que são a representação gráfica de um inventário sistematizado e centralizado de dados geológicos e hidrogeológicos, que objetiva cobrir áreas extensas usando formas homogêneas de interpretação, representação e escala.

A outra tendência (o segundo momento) de desenvolvimento dos estudos hidrogeológicos estão voltados a temas específicos, endereçados a demandas especiais e caracterizam-se pela sua grande variabilidade de tipos, podendo ou não pertencer aos levantamentos regionais.

Os mapas derivados (Struckmeier \& Krampe 1992) resultantes desses estudos específicos, podem ser ramificações e saídas gráficas dos mapas e bases de levantamentos hidrogeológicos sistemáticos, cujos temas representados são direcionados a problemas específicos, servindo a um grupo bem definido de usuários.

Estes tipos de mapas ("problem-oriented hydrogeological maps") são elaborados para melhorar o uso do conhecimento hidrogeológico em planejamento, desenvolvimento e proteção de recursos naturais, por meio de técnicas modernas de armazenamento e gerenciamento de dados em sistemas de informação. 
Os autores consideram também que algumas destas cartas derivadas podem ser simplistas para o profissional hidrogeólogo, porém podem justamente atender as necessidades do leigo, como políticos, alguns planejadores e homens de decisão.

A tabela 1, de autoria de Struckmeier \& Krampe (1992), esquematiza a classificação de vários tipos de mapas que podem ser produzidos em função do nível de , informação disponivel, do uso do mapa e dos parâmetros de representação.

Tabela 1 - Representação gráfica em hidrogeologia em relação ao nivel de informação e uso possivel (Struckmeier \& Krampe 1992).

\begin{tabular}{|c|c|c|c|}
\hline $\begin{array}{l}\text { nivel de informação } \\
\text { uso possivel }\end{array}$ & $\begin{array}{c}\text { baixo } \\
\text { (dados escassos e } \\
\text { heterogêneos de vá- } \\
\text { rias fontes) }\end{array}$ & $\begin{array}{l}\text { âvancado } \\
\text { (mais programas de } \\
\text { investigação sistemá- } \\
\text { ticas, dados mais } \\
\text { confiáveis) }\end{array}$ & $\begin{array}{c}\text { alto } \\
\text { (mais análises hidro- } \\
\text { lógicas de sistemas e } \\
\text { modelos de água } \\
\text { subterrânea) }\end{array}$ \\
\hline$e x$ & $\begin{array}{c}\text { MAPA } \\
\text { HIDROGEOLÓGICO } \\
\text { GERAL } \\
\text { (mapa de aqüifero) }\end{array}$ & $\begin{array}{c}\text { MAPAS DE } \\
\text { PARÂMETROS } \\
\text { HIDROGEOLOGICOS } \\
\text { (série de mapas, atlas) }\end{array}$ & $\begin{array}{l}\text { MAPAS REGIONAIS } \\
\text { DE SISTEMAS DE } \\
\text { AGUA } \\
\text { SUBTERRÂNEA } \\
\text { (modelos conceituais } \\
\text { de representação) }\end{array}$ \\
\hline & $\begin{array}{c}\text { RECURSOS } \\
\text { HIDRICOS } \\
\text { SUBTERRÂNEO }\end{array}$ & \multirow{2}{*}{$\begin{array}{l}\text { MAPAS } \\
\text { HIDROGEOLÓGICOS } \\
\text { ESPECÍFICOS } \\
\text { (mapas de planejamen- } \\
\text { to) }\end{array}$} & \multirow{2}{*}{$\begin{array}{c}\text { REPRESENTAÇÃO } \\
\text { GRÁFICA DERIVADA } \\
\text { DE SISTEMAS DE } \\
\text { INFORMAÇŐES } \\
\text { GEOGRAFICAS } \\
\text { (mapas, seçठes, blo- } \\
\text { cos-diagrama e cená- } \\
\text { rios) }\end{array}$} \\
\hline $\begin{array}{r}\text { gere } \\
e\end{array}$ & $\begin{array}{c}\text { MAPA DE } \\
\text { VULNERABILIDADE } \\
\text { DA AGUA } \\
\text { SUBTERRÂNEA }\end{array}$ & & \\
\hline $\begin{array}{r}\text { parâmetros de } \\
\text { ser }\end{array}$ & \multicolumn{3}{|c|}{ 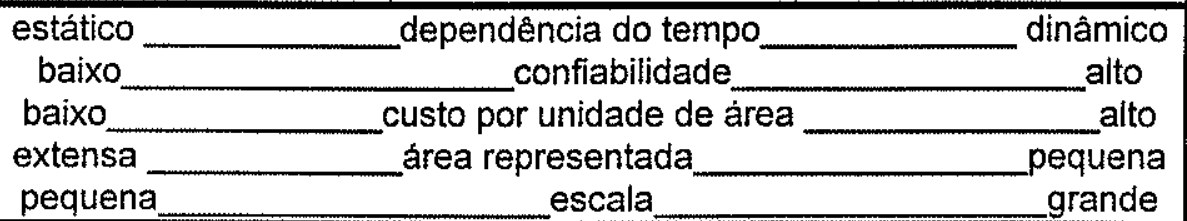 } \\
\hline
\end{tabular}

Dentro dessa classificação de Struckmeier \& Krampe (1992) e da abordagem histórica dos trabalhos de hidrogeologia, alguns exemplos internacionais e nacionais são apresentados e analisados.

Os estudos de avaliações regionais são normalmente desenvolvidos objetivando metas como o conhecimento do potencial desse recurso hídrico em uma região $e$ ou o atendimento para planejamento regional, abastecimento rural, uso do solo e assentamentos humanos. 
Os trabaihos da Geological Survey of Canada - GSC (1967), da Carta Hidrogeológica de Moçambique (Ferro \& Bouman 1992) e os estudos da Bacia do Rio da Prata (Organização dos Estados Americanos - OEA 1971) são avaliações hidrogeológicas regionais baseadas nas sínteses das informações existentes do conhecimento hidrogeológico do momento. Em geral, os estudos abrangem extensas regiōes, no caso todo o Canadá, Moçambique e a Bacia do Rio do Prata, e são aqui considerados como estudos de reconhecimento de avaliação do recurso. Os níveis de informação são heterogêneos, e com problemas de falta e baixa confiabilidade de dados em algumas regiões da Bacia do Rio da Prata e Moçambique. Face aos objetivos desses levantamentos, a base de informação e à área de investigação, as escalas de trabaIhos são bem pequenas, 1:7.603.200 (GSC 1967) e 1:3.000.000 (Ferro \& Bouman 1992 e OEA 1971).

Os levantamentos executados no Canadá (GSC 1967) e na Bacia do Rio da Prata (OEA 1971) representam as primeiras etapas do processo histórico dos estudos hidrogeológicos, onde a representação hidrogeológica restringia-se às formações geológicas e efetivamente sem uma espacialização dos parâmetros hidrogeológicos avaliados; no entanto, com a análise das condições de alimentação (pluviometria e hidrologia) há uma idéia de dinâmica do meio estudado. Já os estudos de Moçambique (Ferro \& Bouman 1992), apesar de recente, apresenta as mesmas características desses dois estudos mais antigos, haja visto as limitações de nível de informação a respeito da água subterrânea na região.

Em relação à cartografia hidrogeológica, Margat (1981) propõe para a Carta Hidrogeológica da França (escala 1:500.000) uma evolução do modo de representação, foi por meio de modelização de certos número de sistemas aqüiferos regionais, classificados pelo modo de alimentação, regime de escoamento de aqüiferos livres ou confinados e conexão com os cursos de água. Isto sobrepõe a natureza litológica de seus reservatórios, bem como as condições limites combinadas com os fatores estruturais e hidrodinãmicos. Para a confecção da cartografia, o autor elaborou uma síntese dos conhecimentos hidrogeológicos atualizados.

A avaliação hidrogeológica regional na ltha da Reunião (Gourgand, Stieljes \& Daesslé 1988) resultou em um Atlas Hidrogeológico (escala 1:2.000.000), voltado principalmente à exploração, disponibilidade, usos (abastecimento, irrigação, água 
mineral e indústria) e consumo. A análise da alta pluviosidade da região é bem detaIhada, pois é responsável pela existência de rios permanentes e grandes reservas de água subterrânea. É um trabalho voltado a temas específicos (potencialidade e exploração do recurso) que procura avaliar as condições de alimentação, uma vez que é um fator vital para o recurso subterrâneo.

" Um outro exemplo de avaliação hidrogeológica regional, mais atualizada, é representado pelo trabalho de United States Geological Survey (U.S.G.S. 1992), cuja área avaliada foi o Sistema. Aqüífero Cambro-Ordoviciano situado na região oeste dos Estados Unidos. Trata-se de um estudo completo, com caracterização hidrodinâmica e condições de ocorrência, hidroquímica e isótopos, caracterização da geometria dos reservatórios de água subterrâneia, exploração e seus efeitos. A dinâmica é representada por meio de modelações matemáticas.

Esses três últimos trabalhos propõem transmitir uma visão mais dinâmica da circulação das águas subterrâneas e de suas condições de ocorrência, não se restringindo apenas às condições estáticas (por exemplo: litologia), mas procurando aprofundar o entendimento de outras áreas como climatologia e hidrologia (condições de recarga de aqüiferos), histórico da exploração e modelação matemática, que influenciam temporalmente no comportamento das águas subterrãneas.

O trabalho de Meister \& Becher (1971) trata de uma avaliação hidrogeológica em escala 1:24.000, das rochas carbonáticas de idade cambro-ordoviciana situadas a sudeste da Pennsilvania, Estados Unidos. Nesse estudo destaca-se a análise estrutural para a avaliação do potencial e adequação aos diversos tipos de uso da água subterrânea. Apesar da escala grande de trabalho, as informações hidrogeológicas ainda se restringem às formações geológicas, face talvez às limitações dos estudos hidrogeológicos na área. Quanto às aptidões, classificaram-se essas formações em função da potencialidade ao uso (abastecimento público e industrial), em excelente, muito bom, bom, regular e pobre.

Essas classificações por aptidões (seja de potencial de exploração ou de uso) das formações aqüiferas nos trabalhos sobre a Bacia do Rio do Prata e no aqüifero situado a sudeste dos Estados Unidos (OEA 1971 e Meister \& Becher 1971, respecti- 
vamente) podem representar aqui o início do desenvolvimento das cartas derivadas ou temáticas, que transmite de modo direto e simples informaçōes ao usuário leigo.

Os levantamentos hidrogeológicos sistemáticos são em muitos países, atribuições de responsabilidade de órgãos governamentais, e objetiva fornecer informações básicas do conhecimento das águas subterrâneas nos estados ou paises, por meio de trabalhos sistemáticos em escalas que variam de regionais (geralmente 1:100.000 ou 1:50.000) a locais (1:25.000 a 1:10.000), dependendo do país, de sua história de desenvolvimento cultural e econômico.

Assim, destacam-se os trabalhos do Instituto Geológico do Comitê do Estado de Geologia da Romênia (1956), que elaborou um mapeamento hidrogeológico básico, com escala 1:100.000, que cobre todo o país, bem como os levantamentos sistemáticos elaborados pelos serviços geológicos de países de primeiro mundo, como os Estados Unidos (United States Geological Survey - U.S.G.S.), Reino Unido (British Geological Survey - B.G.S., dentre muitos outros). Em geral, esses estudos consistem basicamente de caracterização das condições de ocorrência das águas subterrâneas, potenciometria da área, classificação química das águas, caracterização hidrodinâmica, exploração e potencial, uso e demanda, podendo ou não possuir uma modelização da região estudada.

Em escalas maiores, os estudos sistemáticos elaborados possuem uma abordagem mais especifica, cujos temas desenvolvidos foram determinados em função de caracteristicas particulares dos aqüiferos e/ou atividades sócio-econômicas locais. Os trabalhos da U.S.G.S., nos Condados de Pike e Fayette (respectivamente Davis 1989 e McElroy 1988), Pennsilvania (Estados Unidos da América), consistem de levantamentos dos recursos hídricos subterrãneos na escala 1:50.000, porém destacando os estudos relativos à precipitaçăo, fator de grande influência na recarga da água subterrânea da região, no Condado de Pike, e os estudos sobre a quantidade e qualidade da água subterrânea e os impactos causados na mineração de carvão, no Condado de Fayette.

Wagner, Zomenis \& Plöthner (1990) executam um estudo hidrogeológico na região entre Nicosia, Larnaca e Limassol, no Chipre, relativo à qualidade da água dos principais aqüiferos da região para consumo doméstico e irrigação, fornecendo subsídios para o gerenciamento do recurso hídrico subterrâneo e para um planejamento 
realmente efetivo. As avaliações hidrogeológica e hidroquímica delinearam capacitações e restrições na utilização da água subterrânea e definiram susceptibilidades para dois tipos principais de demanda: uso doméstico e irrigação. O estudo se justifica pela presença de impactos na qualidade da água subterrânea provocada pelo aumento da salinidade devido à exploração (irrigação e uso doméstico), intrusão salina em aqüiferos costeiros e contaminação proveniente das atividades agrícolas e industriais.

Esse trabalho representa o terceiro momento do processo histórico dos estudos hidrogeológicos, destacando a utilização de cartas temáticas (escala 1:100.000), que apresentam a susceptibilidade da água subterrânea para uso doméstico nas principais unidades hidrogeológicas (unidades litológicas), classificadas em: geralmente de uso irrestrito, usualmente restrito e restrito, bem como a susceptibilidade à contaminação da água subterrânea proveniente de rejeitos domésticos e industriais e da agricultura, onde estão representados as unidades hidrogeológicas e a susceptibilidade à irrigação. Existem quatro grupos desta susceptibilidade: geralmente irrestrito, restrito para certos usos pelo alto teor de sulfato de cálcio ou ao risco de salinização do solo, e restrito. As extensões e a produtividade dos principais aqüiferos estão descritas conjuntamente às classificações das susceptibilidades.

Atualmente, o conhecimento hidrogeológico não se restringe apenas aos profissionais da área, mas também em atender uma demanda constituida por pessoas leigas. Essa necessidade, que já era existente há algum tempo, cresceu substancialmente em consequência do aumento de trabalhos integrados de planejamento e análise ambiental, onde hidrogeológos trabalham com profissionais de outras áreas e devem dar respostas simples e diretas a um público mais exigente. Por outro lado, a água subterrânea em muitos países é o recurso hídrico mais importante para o abastecimento público, e casos de contaminação em aqǘferos ocasionados pelas atividades industriais, urbanas e agropecuárias, impulsionaram o desenvolvimento da pesquisa de contaminação, como também conscientizaram populações e tomadores de decisão da importância da água subterrânea.

A cartografia é o recurso mais utilizado para essa transmissão do conhecimento, pois "traduz"e sintetiza o conhecimento hidrogeológico, bem como espacializa os resultados, facilitando a compreensão do usuário. 
Essa preocupação com o público leigo é apresentada por Struckmeier e Margat (1989), que discutem os temas proferidos no Colóquio Internacional sobre "Cartografias Hidrogeológicas a Serviço do Desenvolvimento Econômico e Social", onde, dois temas desenvolvidos eram relativos aos usuários ("Demanda dos usuários das cartas hidrogeológicas: criticas das cartas existentes e demandas futuras", e "Significação das cartas hidrogeológicas para o planejamento, o desenvolvimento e a gestấo dos recursos em água subterrânea: estudos de caso onde cartas hidrogeológicas ou a ausência da carta hidrogeológica podem influenciar os projetos, o planejamento, o desenvolvimento e a gestão da água subterrânea e a utilização dos solos").

Dentre muitos resultados deste colóquio, destacam-se o diálogo entre os produtores e usuários da cartografia hidrogeológica, onde idéias e sugestões foram feitas aos hidrogeólogos por planejadores, engenheiros, ecologistas e pelo público, bem como a necessidade de instrução aos usuários inexperientes do melhor modo de usar uma carta.

A existência de cartas hidrogeológicas para o planejamento, o desenvolvimento, a gestão e a proteção do meio ambiente são apresentados, como também as perdas econômicas causadas pela ausência de documentos de planejamento e de gestão adequadas. Estes exemplos devem ser levados aos homens de decisão (políticos, economistas e executivos) pelos hidrogeólogos.

Na mesa redonda, também foi evidenciada a importância das cartas hidrogeológicas para planejamento e explotação dos recursos hídricos, gestão e proteção do meio ambiente nos paises em desenvolvimento. Os fundamentos, no entanto, devem ser adaptados às condições destes paises.

As técnicas mais avançadas de cartografia hidrogeológica e dos estudos hidrogeológicos é o uso cada vez mais constante do Sistema de Informação Geográfica (GIS ou SIG), facilitando principalmente o desenvolvimento de cartas temáticas.

No trabalho de Peverieri et alii. (1991), para estudos, conservação e gestão dos recursos hídricos subterrâneos na bacia hidrográfica do rio Ofanto (Itália), o GIS tem a função de ser o sistema central de gerenciamento do banco de dados gráficos e alfanuméricos, que possui interface com programas aplicados. Nos estudos hidrogeológicos são utilizados modelação matemática dos aqüiferos, modelos de simulação hidro- 
lógica, modelos digitais, representação gráfica dos resultados, gerenciamento de bases de dados e gerenciamento de água subterrânea em modos vetoriais e raster.

Outras aplicações do GIS em água subterrânea são exemplificados em Cornier, Jackou \& Karbo (1991) na República da Nigéria, com o GIS Signer, criado para acoplar bases de dados (informações pluviométricas e climatológicas, recursos hídricos e demanda, dados de censo populacional, etc.), e executar os modelos de simulação de água subterrânea e análises estatísticas.

Simonot \& Walraevens (1991) utiliza-o para a gestão de recursos hídricos em Mali, onde são editados cartas temáticas como potencialidade dos recursos hídricos - subterrâneos, obtidos por superposição numérica e superposição visual de diversas cartas temáticas.

Muñoz \& Langevin (1991) utiliza o GIS na elaboração de duas cartas: de vulnerabilidade e sensibilidade à poluição das águas subterrâneas na Guatemala. A carta de vulnerabilidade foi composta por quatro fatores selecionados: zona não saturada (diferença entre a cota topográfica e a superfície piezométrica), declividade topográfica, densidade de drenagem das águas superficiais e fraturamento, por ponderação de parâmetros. Estes parâmetros foram combinados entre si para se obter uma imagem final que se constituirá na carta de vulnerabilidade. A carta de sensibilidade do meio subterrâneo aos riscos de poluição é função das atividades antrópicas, ou seja, a ocupação dos solos.

O trabalho de Oude Munnink \& Geirnaert (1991) utilizaram o Sistema de Informação Geográfica para projetar uma rede de monitoração de pontos não poluídos por meio da análise de mapas de tipo de solo, recarga e descarga, que foram digitalizadas e divididas em unidades homogêneas.

No contexto nacional, os estudos de avaliação hidrogeológica sistemática se restringem a algumas regiões do país e não possui caráter contínuo. Infelizmente trata-se de "momentos políticos" de períodos favoráveis ao desenvolvimento deste trabalho básico e de iniciativas de alguns profissionais.

A inexistência de levantamentos hidrogeológicos sistemáticos interfere no desenvolvimento e execução da cartografia hidrogeológica nacional. Alguns trabalhos cartográficos são expostos, porém tratam-se de resultados de estudos de iniciativa de 
alguns órgãos de pesquisas ou projetos acadêmicos, que abrangem regiões ou áreas e/ou temas especificos.

No período entre 1970 e 1981, elaborou-se uma estratégia de gerenciamento dos recursos hídricos subterrâneos em São Paulo, iniciando com estudos de levantamento hidrogeológico que abrangeu todo o estado (DAEE 1974, 1975, 1976, 1977, 1979a, 1979b, 1981a e 1981b). Estes trabalhos consistiram, por Região Administrativa, da avaliação hidrológica, balanço hídrico e caracterização dos recursos hídricos subterrâneos por Sistemas Aqüíferos, com a análise da hidrodinâmica, hidrogeoquímica e qualidade das águas, aspectos construtivos dos poços tubulares profundos, perfil do usuário e do consumidor das águas subterrâneas. Estes produtos resultantes foram embasados nas informações de um amplo cadastramento de poços tubulares profundos realizado no período. Como seqüência deste trabalho de avaliação sistemática, Campos (1993) apresenta uma caracterização hidrogeoquímica das províncias hidrogeológicas, com proposta de uma cartografia a nível do estado de São Paulo, em escala 1:1.000.000, e a elaboração da carta hidrogeológica do estado em fase final de execução, de escala 1:500.000 (DAEE, no prelo). A falta de recursos humanos, estruturais e financeiros, e de apoio político, atrasaram alguns projetos que seriam decorrentes destes levantamento, como essa carta hidrogeológica.

A Lei Estadual $n^{0} 6.134(02 / 06 / 88)$ e sua regulamentação, o Decreto-Lei $n^{\circ}$ 32.955 (07/02/91), são os aspectos legais e a continuidade do processo desencadeado pelo levantamento sistemático. No entanto, a falta de uma estruturação dos órgãos responsáveis pela gestão, fiscalização e controle das águas subterrâneas resultou na quebra dessas ações programadas e conseqüente desatualização dos cadastros e não cumprimento da lei.

Desde 1990, os estudos de avaliação hidrogeológica para planejamento territorial, é executado pelo Instituto Geológico na região entre Sorocaba e Campinas e Região Metropolitana de Campinas (IG 1990a, 1990b, 1991, 1993, 1995). Os projetos consistiram de uma atualização do cadastro de poços tubulares profundos na região investigada, determinação da hidrodinâmica e hidrogeoquímica, produtividade e análise da vulnerabilidade natural dos aqüiferos. O mapeamento geológico e geomorfológico, de mesma escala de trabalho, foi realizado na mesma área de estudo, facilitando e melhorando a análise hidrogeológica. A investigação é feita sobre a situação das obras de captação, uso das águas subterrâneas, cálculos de reservas e consumo de 
recurso hidrico. Algumas cartas temáticas foram desenvolvidas para o planejamento, como produtividade, vulnerabilidade e carta orientativa ao usuário. Os mapas resultantes encontra-se na escala 1:50.000, em sua maioria.

A Companhia de Pesquisa de Recursos Minerais (CPRM) desenvolve no Piauí o Programa de Apoio à Gestão de Águas Subterrâneas (PAGAS), onde já inventariou cerca de quarenta municípios desse estado. O trabalho de Branco, Vinha e Soares Filho (1995) apresenta resultados de estudos utilizando este inventário nos municípios de Oeiras e Picos (sul de Teresina) e o Sistema de Informações Geográficas (SIG). Os mapas produzidos foram tratados geoestatisticamente e são os seguintes: mapas de isovazões de teste e de isovazões específicas (produtividade), superficie de tendência da salinidade, superfície de tendência da cota do nivel estático, para todos os aqüiferos existentes em Oeiras e Picos e especificamente para os aqüiferos Cabeças e Serra Grande.

Os mapas de zonas de favorabilidade de exploração das águas subterrâneas são resultados e sintese das áreas de maior potencial de disponibilidade e produtividade.

No Rio Grande do Sul, a CPRM desenvolveu no Programa Levantamentos Geológicos Básicos, o projeto Mapas de Previsão de Recursos Hidricos Subterrâneos. O mapa hidrogeológico de Santa Maria, escala 1:100.000 é um resultado deste projeto e contém informações hidrogeológicas da região, onde estão dispostas estratigraficamente os aqüiferos locais e descritas suas importâncias hidrogeológicas relativas, o zoneamento hidroquímico e balanço hidrico, como informações auxiliares, e condições prováveis de aproveitamento das águas subterrâneas (CPRM 1994).

O mapeamento de vulnerabilidade e risco de poluição das águas subterrâneas no Estado de São Paulo (IG/CETESB/DAEE 1993), é um dos primeiros estudos que elaboram cartas temáticas, que são: Carga Contaminante Potencial - fontes pontuais, Carga Contaminante Potencial - fonte saneamento in situ e quantidade de residuos sólidos gerados, e o Mapa de Vulnerabilidade da Contaminação de Aqüíferos.

A caracterização da vulnerabilidade natural de um aqüifero é determinado por combinações de fatores ou parâmetros disponiveis como: tipo de ocorrência da água subterrânea (ou condição do aqüifero), as características dos estratos acima da zona não saturada (grau de consolidação e tipos litológicos) e a profundidade do nivel da água, de acordo com o método proposto por Foster \& Hirata (1991). A caracterização 
da carga contaminante no subsolo foi dividida em contaminação por fontes difusas e pontuais. As cargas contaminantes potenciais de fontes pontuais foram separadas em atividade industrial, disposição de resíduos sólidos, lagoa de efluentes e atividade mineira. As fontes dispersas avaliadas foram as áreas urbanas sem rede de esgoto.

O cruzamento da vulnerabilidade natural e a carga potencial de contaminantes gera os graus de riscos de contaminação das águas subterrâneas.

Hirata (1994) aplicou o conceito de vulnerabilidade no município de São José dos Campos, mapeado na escala 1:25.000, juntamente com a carga contaminante. Este estudo estabeleceu áreas de risco e os poços tubulares usados para abasteci- mento público tiveram seus perímetros de proteção traçados.

Outros métodos de vulnerabilidade foram desenvolvidos. Zuquette et alii. (1993) e Nishimura \& Zuquette (1994) apresentam um método para cartografia do potencial de risco à contaminação das águas subterrâneas, baseados em parâmetros geotécnicos, como profundidade do substrato rochoso, textura do solo, estrutura, consistência, níveis de umidade, capacidade de troca cationica, $\mathrm{pH}$, delta $\mathrm{pH}$, niveis de nutrientes, pedregosidade, capacidade de campo, porcentagem de matéria orgânica, saturação de bases, profundidade do nivel freático, drenabilidade, declividade, indice de vazios, homogeneidade, salinidade e sódio trocável. A definição das unidades de riscos à contaminação foi baseada nas áreas de recarga, insumos químicos (fertilizantes) e práticas agrícolas, constituição do meio físico (perfil de alteração ou dos materiais inconsolidados) na área vadosa. As unidades foram definidas por perfis de material inconsolidado e caracterizados quanto sua espessura e permeabilidade. Por fim, estas unidades foram divididas nas classes de alto potencial, potencial intermediário e baixo potencial.

O método da caracterização da vulnerabilidade dos autores acima citados é baseado apenas nas características do material inconsolidado, objeto de análise principal dos estudos geotécnicos, sem considerar as condições hidrogeológicas locais. Para uma escala de nivel regional (1:100.000), esta metodologia envolve ensaios de laboratórios para determinação de muitos parâmetros que definirão esta vulnerabilidade, que pode onerar o projeto em termos de tempo de execução e custos.

Os trabalhos acadêmicos de estudos hidrogeológicos possuem caráter especifico, onde estes estudos detalham ou determinada região, sistema aqüifero ou a metodologia utilizada é especial e inédita. Entretanto, apesar de tratar de temas especifi- 
cos, consistem no avanço do conhecimento da circulação dos aqüíferos estudados, na análise de suas condições potenciais de exploração, cálculo de reservas (permanentes ou renováveis ou outras), hidroquímica e qualidade das águas subterrâneas.

Em escala regional, citam-se os trabalhos de Silva (1983), que investigou os mecanismos de evolução química, origem, idades aparentes e velocidades de circulação dás águas subterrâneas do Aqüifero Botucatu do Estado de São Paulo, aplicando o uso de técnicas hidroquímicas e isotópicas $\left({ }^{18} \mathrm{O},{ }^{2} \mathrm{H},{ }^{13} \mathrm{C}\right.$ e $\left.{ }^{14} \mathrm{C}\right)$ amostradas em poços selecionados, situados nas mais diversas porções do aqüífero em todo o estado. Parisot (1983) executou um estudo sobre as águas subterrâneas na região centrooeste do município de São Paulo, que objetivou diagnosticar a situação atual do aproveitamento das águas subterrâneas e suas características químicas e relações com o ambiente. A autora não utiliza o conceito de vulnerabilidade à poluição dos aqüíferos, como uma característica intrinseca do aqüífero, pois é avaliada pela integração de fatores hidrogeológicos (tipo de aqüífero, profundidade do nivel de água, litologia, interrelações com águas superficiais, etc..), conjuntamente com fatores humanos (ocupação do solo, urbanização, indústrias, agriculturas), definindo zonas de graus diferentes de vulnerabilidade efetiva (baixa, média e alta).

Silva (1984) aprofunda o conhecimento do aqüifero cárstico do Jaíba, norte de Minas Gerais, por meio da análise morfoestrutural (fraturas e dolinas), hidrogeológica e hidroquímica. Com base nestas técnicas definiram-se as características e as potencialidades dos aqüíferos. Zonas de características tectônicas e de carstificação foram determinados, e a influência dos fraturamentos no controle das drenagens da área. A análise de tendência, agrupamento e fatorial foi o recurso técnico estatístico utilizado no tratamento e interpretação dos dados.

E um dos primeiros autores a utilizar a cartografia temática. A integração das informações produziu uma carta síntese, o Mapa de Síntese Hidrogeológica, onde delimitaram-se zonas homogêneas (ou com características semelhantes) de maiores potencialidades do recurso hídrico subterrâneo. Esta integração maior citada acima é fruto de mapas sínteses parciais, de zoneamento hídrico (estudos das feições morfoestruturais e da características dimensionais e hidrodinâmica do aqüifero) e do zoneamento geohidroquímico (obtendo zonas com diferentes graus de recarga e indícios de contaminação). 
Bertachini (1987) apresenta uma avaliaçăo hidrogeológica e hidroquimica em terrenos cristalinos na região de Jundiaí (SP), onde foram utilizados modelos de fraturamentos regionais para explicar a produtividade dos poços tubulares profundos e a hidrogeoquímica para identificar os principais fenômenos modificadores e tempo de residência das águas subterrâneas.

Menegasse \& Duarte (1990) analisaram a influência dos condicionantes litoestruturais na produtividade de poços tubulares profundos em terrenos metamórficos na Folha de Santana do Parnaiba, determinando-se dois meios de circulação de água nas zonas fraturadas: os condutos de dissolução interconectados das rochas carbonáticas e as fraturas abertas.

A avaliação hidrogeológica realizada no município de Tietê (SP) por Diniz (1990) objetivou basicamente a caracterização dinâmica e produtiva da Formação Tietê, a análise da recarga deste aqüifero, por meio do cálculo do balanço hídrico, a caracterização hidroquímica e isotopia das águas subterrâneas e do potencial renovável anual. Os resultados permitiram concluir as excelentes perspectivas para captação de água na Formação Tietê, haja visto os valores de transmissividades e vazões obtidos, a boa qualidade da água subterrânea e a estimativa da recarga de 100 $\mathrm{mm} / \mathrm{ano}$.

Cavalcante (1990) realiza estudo hidrogeológico na região de Atibaia (SP), em área de terreno cristalino com manto de intemperismo, e objetivou a caracterização das condições de ocorrência da água subterrânea, a avaliação das obras de captação e a apresentação de uma proposta metodológica de estudo hidrogeológico para este meio. A caracterização hidroquímica também é executada. Duas zonas aqüiferas foram então definidas: o manto de intemperismo, que pode funcionar como aqǘfero principal ou de transferência, com vazão média de $0,9 \mathrm{~m}^{3} / \mathrm{h} / \mathrm{m}$ e o aqüifero fraturado, com vazão abaixo de $10 \mathrm{~m}^{3} / \mathrm{h}$ e capacidade especifica média de $6 \times 10^{-2} \mathrm{~m}^{3} / \mathrm{h}$ por metro de rebaixamento.

Celligoi (1993) estuda o comportamento das águas subterrâneas em aqüíferos basálticos da Formação Serra Geral no município de Londrina, sob a ótica dos condicionantes litológicos, estruturais e geomorfológicos destes derrames. As áreas de maior potencial produtivo (destacando-se os lineamentos E-W) encontram-se nas descontinuidades lito-estruturais das rochas, que estão representadas e delimitadas 
em mapas de escala pequena. As águas subterrâneas são classificadas como bicarbonatadas cálcicas e são potáveis para consumo humano.

Lopes (1994) avalia as condições de ocorrência da água subterrânea nas bacias dos rios Piracicaba e Capivari, por meio da realização de um diagnóstico da situação de uso atual, disponibilidade e perspectivas de aproveitamento. A metodologia está embasada nas informações cadastrais de poços tubulares profundos, dados hi'drológicos, geológicos e hidrogeológicos, consumo e demandas de água subterrânea e balanço hídrico das bacias.

A avaliação hidrogeológica da Bacia do Baquirivu-Guaçu (Diniz 1996), região de Guaruihos e Arujá, constou da análise do contorno estrutural sob os sedimentos da Bacia Sedimentar de São Paulo, com a identificação do Gráben do BaquirivuGuaçu e sua interrelação com a produtividade dos poços tubulares profundos, análise da produtividade do aqüifero cristalino e sedimentar, análises de testes de bombeamento para caracterização hidrodinâmica dos aqüiferos, balanço hídrico e cálculos das reservas renováveis e permanentes.

Os estudos de áreas menores são exemplificados a seguir:

O estudo de Yoshinaga (1990) teve como finalidade caracterizar as águas minerais das fontes e poços tubulares de Águas de Lindóia e Lindóia (SP), quanto a sua origem e dinâmica, por meio da análise geológica/estrutural, do comportamento hidrodinâmico, químico e isotópico, e assim proporcionar um maior e melhor entendimento da hidrogeologia e hidrogeoquímica de rochas fraturadas.

A avaliação do potencial hidrogeológico da Cidade Universitária de São Paulo é um exemplo de estudo de detalhe executada em uma área de $4,3 \mathrm{~km}^{2}$ (Iritani 1993). Os procedimentos aplicados no estudo consistiram na aplicação de métodos indiretos e diretos de investigação e monitoração. Os trabalhos executados foram: cadastramento de poços tubulares profundos, levantamento e perfilagem geofísica, implantação de rede de monitoração do nível de água dos poços de observação, amostragens e análises hidroquímicas da área e testes de vazão. Os resultados obtidos foram uma avaliação de detalhe sobre a geometria do aqüífero, determinação de áreas com potencial de exploração e cálculo das reservas permanentes e reguladoras. Os mapas encontram-se na escala 1:20.000. 


\subsubsection{Estudos do Meio Físico com enfoque ao Planejamento e Análise}

Ambiental

Primeiramente, uma análise de métodos de estudos do meio físico existentes das diversas áreas das geociências com enfoque ao planejamento (urbano e territorial) e meio ambiente é desenvolvida; apresenta-se e discute-se, então, as metodologias nacionais e internacionais e sua aplicação nos campos da geomorfologia, geologia de engenharia e geotecnia. Esta análise visa compreender os principais fundamentos metodológicos para direcionar, criar e/ou adaptar seus principios e procedi-m mentos mais importantes aos estudos hidrogeológicos sob este enfoque.

Nos estudos de geologia ambiental e de planejamento analisados, a água subterrânea é sempre abordada, porém de modo superficial. Deste modo, uma visão da aplicação da hidrogeologia com base na bibliografia de geologia de planejamento e ambiental existentes serve de ponto de partida para a elaboração de uma proposta metodológica de estudos hidrogeológicos para planejamento urbano, territorial e ambiental.

A cartografia aplicada a esses estudos também é avaliada e discutida, pois espacializa os resultados técnicos, bem como é um instrumento de integração das informações multidisciplinares necessárias ao planejamento territorial e ao meio ambiente. Os procedimentos cartográficos usuais, tanto nos estudos citados, como na hidrogeologia, são analisados, podendo adaptá-los ou adotá-los para a execução de uma cartografia hidrogeológica própria.

Os estudos do meio físico compreendem basicamente o entendimento do ambiente como um todo, onde todos os seus atributos se interagem de uma forma dinâmica; e têm como meta indicar diretrizes para um melhor planejamento de uso e ocupação ou preservação deste ambiente.

Os métodos de estudo são distintos, pois variam de acordo com sua finalidade e a área(s) de conhecimento(s) sob enfoque. Pires Neto (1994) explica que a parcialidade da visão do ambiente é atribuída à pessoa observadora, que vê a natureza exposta em relação ao seu método de questionamento e não a natureza propriamente dita.

A grande complexidade do ambiente, as inúmeras variáveis que o compõe e as consequências dos muitos tipos de intervenção antrópica são os responsáveis pela 
necessidade dos estudos multidisciplinares do meio físico, como também das outras áreas do conhecimento humano (economia, sociologia, antropologia, etc..), para planejamento e análise ambiental. O conhecimento do ambiente em sua totalidade se faz mais necessária para um melhor gerenciamento dos recursos naturais e otimização do espaço físico ocupado pelo homem.

Um dos primeiros métodos que surgiram objetivou o levantamento de recursos naturais em regiões de pouco conhecimento ou totalmente desconhecidas. A metodologia P.U.C.E. (Patterns Components Evaluation) foi adotada em levantamentos sistemáticos na Austrália. O levantamento da área é desenvolvido por meio de feições geomórficas mapeáveis, sendo possível aplicar essa metodologia em diversas áreas, em função das caracterizações das Classes de Terreno (Província, Modelo, Unidade e Componente - descrição sucinta na tabela 2). Zuquette \& Gandolfi (1988) consideram esta metodologia como uma das mais completas para avaliação do meio físico, e é eficiente em termos de custos, tempo e resultados técnicos em levantamentos regionais de escalas de 1:250.000 ou menores.

Tabela 2 - As classes de terreno da metodologia P.U.C.E. (modificado de Zuquette \& Gandofi 1988).

\begin{tabular}{|l|l|l|}
\hline \multicolumn{1}{|c|}{$\begin{array}{c}\text { ClASSES DE } \\
\text { TERRENO }\end{array}$} & \multicolumn{1}{|c|}{$\begin{array}{c}\text { FATORES DE TERRENO } \\
\text { DESCRITOS }\end{array}$} & \multicolumn{1}{c|}{$\begin{array}{c}\text { MODELO PARA EXPRESSÃo DO } \\
\text { RESULTADo }\end{array}$} \\
\hline PROVÍNCIA & $\begin{array}{l}\text { geologia (grupo, formação, } \\
\text { etc..) }\end{array}$ & $\begin{array}{l}\text { mapas de 1:250.000 ou maior; ou- } \\
\text { tros. }\end{array}$ \\
\hline $\begin{array}{l}\text { PADRÃO DE } \\
\text { TERRENO }\end{array}$ & $\begin{array}{l}\text { paisagem, tipos básicos do } \\
\text { solo, vegetação, rochas, } \\
\text { padrão de drenagem }\end{array}$ & $\begin{array}{l}\text { mapa 1:250.000 ou maior, blocos } \\
\text { diagramas da paisagem e da as- } \\
\text { sociação de cuidados do terreno. }\end{array}$ \\
\hline $\begin{array}{l}\text { UNIDADES DE } \\
\text { TERRENO }\end{array}$ & $\begin{array}{l}\text { formas de relevo, principais } \\
\text { tipos de solo, rochas e for- } \\
\text { mações vegetais }\end{array}$ & $\begin{array}{l}\text { mapas em escala 1:25.000 a maior } \\
\text { com as diversas associações. }\end{array}$ \\
\hline $\begin{array}{l}\text { COMPONENTES } \\
\text { DO TERRENO }\end{array}$ & $\begin{array}{l}\text { tijolo de talude, litologia, } \\
\text { solo, associações }\end{array}$ & $\begin{array}{l}\text { mapa 1:2.500 ou maior com os } \\
\text { detalhes exigidos pela classe. }\end{array}$ \\
\hline
\end{tabular}

O trabalho de Mabbut \& Stewart (1963) exemplifica a aplicação do conceito de Sistema de Terreno (Land System) nos levantamentos de reconhecimento de recursos naturais realizados em New Guinea e Austrália, por meio de delimitação de áreas com padrão repetente de formas de terreno, solos e vegetação. Os autores afirmam que alguns tipos de mapas de sistemas de terreno não são explorados, exemplifican- 
do com o mapa de sistemas de terreno específico de hidrologia de superfície, demonstrando a potencialidade de recursos hídricos de uma região e a aplicação para água subterrânea; os mapas de sistema de terreno com enfoque aos recursos hídricos poderia ser importante em levantamentos gerais dos recursos potenciais de água e em planejamento de investigações hidrológicas.

Astle, Webster \& Lawrence (1969) apresentam a classificação de terreno por 'paisăgens para planejamento na região do Vale de Luangwa, Zambia, dos padrões, com a seguinte graduação: Sistemas de Terreno (Land Systems), em escalas de 1:250.000 a 1:1.000.000; Facetas de Terreno (Land Facets) que pode ser mapeado nas escalas 1:20.000 a 1:50.000; e abaixo destes existem os Elementos de Terreno (Land Elements).

A metodologia de Sistemas de Terreno (Land Systems) é considerada clássica, pois se trata de uma visão naturalista da realidade. A paisagem é conceituada por meio da observação e em bases fisionômicas, sendo essencialmente descritiva (Martinelli 1994).

A metodologia usada pelo C.S.I.R.O. (Commonwealth Scientific and Industrial Research Organization - Austrália) utiliza a metodologia de Sistema de Terrenos, porém dirigida a finalidade do terreno para as atividades humanas (Austin \& Cocks 1978 apud Pires Neto 1994).

A delimitação das áreas homogêneas é dada em dois níveis: em Sistemas de Terreno, que é o conjunto de unidades de terreno que estão geográfica ou geomorfologicamente relacionados por possuírem um mesmo padrão de recorrência de formas de terreno, solo e vegetação, e em Unidades de Terreno, definidas como grupos de locais com uniformidade de alguns atributos em função de um propósito prático (Austin \& Cocks 1978 apud Pires Neto 1994).

Mabbut (1968) apud Pires Neto (1994) apresenta três métodos de estudo do meio físico: o genético, o paramétrico e o de paisagem. O primeiro subdivide o terreno em função dos fatores que influenciam na morfogênese e nas características genéticas. O sistema paramétrico consiste em estudos individuais de vários atributos, de acordo com propósitos específicos, que por fim darão uma visão sintética da área investigada. "O sistema de paisagem envolve múltiplos aspectos e classifica o terreno pelos padrões de suas paisagens componentes", diferenciados, por sua vez, de acor- 
do com sua similaridade de feições visíveis e pela inferência não aparente. O Sistema de Terreno representa o terceiro método definido.

A metodologia de Sanejouand ou francesa (1972), apud Zuquette \& Gandolfi (1988), tem sua aplicação sugerida para áreas de pequena a grande extensão e fundamenta-se em aspectos qualitativos, não fixando classes taxonômicas, atributos ou limites. As cartas de aptidão são os principais documentos desta metodologia e podem "ser utilizadas diretamente pelos usuários. Seu uso frequente é atribuida pelos motivos que se seguem: não estipula classes e limites para nenhum parâmetro, ficando este a critério da equipe executora; a forma de apresentação da documentação é simples, e a análise dos componentes do meio físico possui caráter essencialmente qualitativa (Zuquette \& Gandolfi 1988).

Matheson \& Font (1974) discutem a importância da geologia no planejamento de uso e ocupação do solo e criticam a ausência desta área do conhecimento nos principais programas de planejamento da terra nos Estados Unidos da América, atribuindo esta ausência ao profissional geólogo, que se mantém distante do mundo político e a impossibilidade de se aplicar as soluções geológicas, pois as respostas geológicas ou são afirmações de problemas existentes sem soluções ou estão escritos ininteligivelmente, com jargões geológicos que o planejador não pode e não tentará entendê-los. O sistema esta sistematizado em mapas denominados observacionais e de engenharia, utilizados na sintetização dos mapas de terceira ordem (interpretativos), que mostram o uso de uma área para propósito específico do uso do solo ou apresenta riscos existentes ou potenciais. Os mapas de primeira e segunda ordem são de uso restrito, ao contrário dos mapas de terceira ordem, que são dirigidos para o público. O mapa de quarta ordem é o resultado final de um estudo completo, e é dirigido ao planejador do uso do solo.

Para a análise ambiental, Journaux (1975; 1985), apud Martinelli (1994), apresenta uma classificação metodológica dos diversos mapas, distinguindo-se três níveis: Mapas de Análise, a cartografia dos elementos (ex: as formações vegetais) e dos processos simples (ex: a geomorfologia), os Mapas de Sintese. onde estão representados as associações de elementos ou de processos para definição de Sistemas ou ainda para a realização de Mapas de Aptidão ou de Riscos, e por fim, os Mapas de Sensibilização, que são destinados à conscientização sobre o estado do ambiente e de sua dinâmica e a indicar diretrizes e ações para serem deliberadas no 
planejamento territorial. A superposição e justaposição de mapas com os dados ambientais, de impactos, de degradação, de poluição e de trabalhos de defesa e melhorias, detectam-se entraves ambientais e a tendência de evolução de seus componentes obtendo-se, assim, uma Cartografia Prospectiva.

Tricart (1977) em seus estudos da paisagem, apresenta uma representação cartográfica a partir de uma taxonomia de tipos de unidades ecodinâmicas, relativas aos "graus de sensibilidade do meio ambiente em função dos fenômenos naturais e antrópicos. O "Mapa Ecodinâmico", baseada no estudo do comportamento dinâmico do ambiente, visa evidenciar as várias formas de funcionamento do meio ambiente, considerando três categorias ecodinâmicas principais: os meios estáveis, os meios intermediários e os meios fortemente instáveis.

Os estudos geotécnicos possuem vários métodos de estudos para planejamento e uso e ocupação do solo, desenvolvidos por diversos países.

A I.A.E.G. (Internacional Association of Engineering Geology) elaborou, com base em metodologias de diversos países, um procedimento de mapeamento geotécnico visando a uniformização dos processos de mapeamento para o maior número de paises.

Os mapas podem ser classificados em: propósito especial; múltiplos propósitos, ou em analíticos e compreensíveis (mapas de condições geológicas para fins de engenharia e mapas de zoneamento de geologia de engenharia).

Os mapas adicionais podem ser inclusos, e são agrupados como mapas auxiliares e mapas complementares.

Os exemplos da aplicação dessa metodologia é dada por autores como Dearman et alii. (1979), na área de conurbação de Tyne e Wear, nordeste da Inglaterra, na escala de 1:50.000 e apresentados em escala 1:200.000.

O trabalho de Matula (1979) e Dearman \& Matula (1976) discutem propostas quanto ao aumento do nivel de exatidão em todas as fases principais de processamento da informação da geologia regional., da utilidade dos mapeamentos da geologia de engenharia como fonte de informação do ambiente natural para planejadores e engenheiros, e da importância da cooperação interdisciplinar devido a complexidade dos problemas ambientais. 
Melnikov (1979) apresenta a metodologia aplicada na antiga União Soviética, executado em regiões com desenvolvimento econômico recente e onde ocorrem processos exógenos de geologia e de geologia de engenharia, com métodos de estudo diferentes, aplicados de acordo com a região analisada. $O$ principal documento resultante destes levantamentos é o mapa de condições de geologia de engenharia, na escala 1:200.000, que pode ser reduzido a 1:500.000, em áreas de condições mais 'simples ou aumentado a 1:100.000, em áreas mais complexas. As áreas-chave são executados na escala 1:25.000.

Golodskaya (1979) apresenta uma proposta de mapeamento de geologia de engenharia cujos resultados apoiariam a elaboração de um método de previsão de processos geológicos que poderiam ser desencadeados de acordo com o tipo da atividade de engenharia, facilitando a implementação de uma obra conveniente.

Rónai (1979) apresenta os trabalhos da cartografia geotécnica desenvolvida na Hungria, exemplificando com os estudos de duas regiōes distintas: Budapeste e Scongrád, nas escalas de 1:25.000 e 1:100.000 respectivamente. Os mapas de hidrogeologia e águas com artesianismo, determinando-se a permeabilidade das rochas através de testes de laboratório. A profundidade do nível médio de água é mostrada no mapa por isópacas, como também a composição química dessas águas por diagramas. Estes trabalhos apresentados por este autor não apresentam carta sintese, porém os estudos hidrogeológicos possuem destaque.

Lozinska-Stepien (1979) descreve os principios da execução dos mapas de condições de geologia de engenharia, nas escalas 1:50.000 e 1:25.000 para planejamento regional de áreas urbanas e suas aglomerações. A representação gráfica podem ser feitos em mapas analíticos (mostrando somente um fator singular) ou em mapas sintéticos (mostrando a avaliação total das condições de geologia de engenharia).

Fernandez, Del Mora \& Peña Pinto (1979) apresenta a evolução da cartografia geotécnica na Espanha, e Prado \& Peña Pinto (1979) discutem a metodologia da cartografia geotécnica. Os trabalhos cartográficos estão divididos em geral (escala 1:200.000), básico (1:25.000), seletivo (1:5.000) e especifico (1:2.000) e são relativos à aplicação (nacional, regional, provincial e urbano).

Radbrush-Hall (1979) apresenta diversos estudos e mapas de geologia de engenharia executados nos Estados Unidos, não existindo uma metodologia sistemática 
e uniforme para todo o território devido aos vários propósitos e condições geológicas e ambientais diversas dos trabalhos realizados. Em relação à água subterrânea, esta é referida como risco (subsidência de terrenos resultantes do rebaixamento excessivo da água subterrânea e da tectônica local). Nos EUA, muitos estudos sobre este risco são executados, particularmente em regiões áridas e semi-áridas. Os estudos de água subterrânea como recurso natural (fontes geotermais, lençol freático) também - foram avaliados em função de sua susceptibilidade à contaminação (por metanol, fluídos geotermais, etc..).

Rockaway (1976) discute em seu trabalho as escalas em mapeamentos de geologia de engenharia realizados em Missouri, Estados Unidos, ao longo dos anos, em termos de custo, objetivos, acuracidade, unidades de mapeamento e aplicação potencial do mapa pelo usuário não geólogo.

Johnson \& Luza (1981) realizam trabalho sobre riscos geológicos e impactos potenciais por uso dos solos no Estado de Oklahoma, Estados Unidos. As informações são compiladas de todas as fontes disponiveis e são representadas em mapas base de escala regionais (1:250.000 a 1:750.000).

Merla, Merio \& Oliveri (1979) apresenta um mapeamento de geologia de engenharia de detalhe (escala 1:25.000) em áreas selecionadas na região montanhosa na Itália, resultando em dois mapas: um mapa geológico analítico e um mapa derivado de múltiplos propósitos.

Em Comune de Grosio, Itália, Bakhireva et alii (1994) expõem um trabalho de investigação geoecológica, de caráter expedito (1 mês), que visou: a estimativa das condições geoecológicas do território e construção de modelos cartográficos, demostrando o caráter, grau e escala de poluição de águas superficiais, solo, sedimentos de fundo e vegetação; a estimativa geoquimica de recursos hídricos usada para engenharia e suprimento de água potável; compilação de um mapa esquemático da localização dos monumentos arquitetônicos e históricos e seu inventário; estimativa das propriedades decorativas e de construção do feldspato. O método desta avaliação geoecológica foi o de mapeamento geoquímico, para apresentar um quadro espacial dos poluentes que ocorrem em componentes naturais.

Landry (1979) apresenta um levantamento geotécnico e sua importância para estudos de desenvolvimento urbano em Jizan, Arábia Saudita, objetivando determinar locais favoráveis à implantação de um novo centro urbano, numa área com $100 \mathrm{Km}$ 
de diâmetro ao redor da cidade já existente. O autor observou em análise de detalhe que o ambiente estudado, aparentemente homogêneo, possui restrições em determinados locais à sismicidade, às caracteristicas dos solos para fundações, à evolução morfológica das formações superficiais e as dificuldades de suprimento de água. No contexto hidrogeológico, foram avaliados as possibilidades de suprimento de água potável; o autor concluiu que os melhores locais de captação de água não estão con' dicionados diretamente a escolha do futuro local da nova cidade. As restrições à exploração da água subterrânea são o risco de salinidade em caso de bombeamento excessivo e a má qualidade da água subterrânea.

Shephard-Thorn \& Moseley (1979) avalia o potencial aplicativo dos mapas hidrogeológicos regionais para a geologia de engenharia, apresentando mapas regionais produzidos pela Unidade de Hidrogeologia do Instituto de Ciências Geológicas, da Inglaterra. Estes mapas estão em escala 1:100.000, onde uma base de geologia simplificada é exposta; os aqüíferos e aqüicludes estão representados, assim como os aluviões e depósitos glaciais extensivos e associados. O contorno de niveis mínimos de água subterrânea para aqüiferos principais são expostos nos mapas, juntos com os locais de fontes, entradas de rios, abstrações de água subterrânea licenciada, sondagens de observação, estações de edição de rios e áreas de artesianismo. Um mapa de menor escala ilustram chuvas e relevo, química da água subterrânea e esquemas de água subterrânea de especial interesse. As características hidrogeológicas das formações são apresentadas em breves notas. Os mapas hidrogeológicos confeccionados desta forma proporcionam uma fonte de referência para o engenheiro geólogo, na execução de planejamento preliminar e em estágios de projetos das principais obras lineares.

Hoffman (1976) apresenta um levantamento sistemático em Queensland, Austrália, e um estudo piloto na parte sudeste, região mais populosa do estado. $O$ estudo piloto apresenta seis mapas compreendendo geologia, geomorfologia (com declividade), riscos naturais, materiais extrativos, hidrogeologia e potencial à ocupação urbana do terreno. O último mapa é o síntese, produto da superposição de mapas, mostrando três adequações ao terreno (apropriado, condicionalmente apropriado ou desconhecido e impróprio). O autor propõe para outros estudos, o uso de um mapa de riscos naturais e restrições e um mapa de susceptibilidade do terreno a uma urbanização potencial, baseado em capacidades e restrições físicas. 
Salvatierra (1986 apud Pires Neto 1994) elaborou um estudo de mapeamento geotécnico na Província de Valencia, Espanha, na escala 1:200.000, usando uma metodologia que consiste na elaboração de três gerações de mapas, definidos como:

Descritivos, aqueles que indicam os parâmetros do meio, como relevo, declividades, litologias, clima, etc.., usados na definição de um mapa de unidades geoambientais.

Interpretativos, representam qualidades ou variáveis significativas do terreno em função dos usos do homem.

Orientativos ou Normativos, são mapas que representam as orientações e limi- tações ao uso da terra, feitas com base nos mapas anteriores.

Os mapas elaborados foram: mapas de Unidades Geoambientais, Riscos Geológicos, Erosão Atual, Erodibilidade Potencial, de Interesse à Conservação e de Orientação e Limitações ao Uso. As Unidades Geoambientais foram divididas em Sistemas Morfodinâmicos, com as delimitações feitas nos contatos geológicos, que por sua vez foram subdivididos em Unidades Morfodinâmicas.

Em hidrogeologia, a análise do tipo de aqüifero e a disponibilidade são parâmetros de caracterização das unidades morfodinâmicas; a vulnerabilidade das águas subterrâneas pode ser encontrada nos processos em riscos e nas orientações e em limitações de uso, a preservação das águas subterrâneas é destacada.

Bell et alii (1987 apud Pires Neto 1994) introduz em seu trabalho "Aspects of geology in planning", o tema poluição de aqüiferos e aterros de resíduos como riscos geológicos induzidos pelo homem nos estudos de mapeamento geológico-geotécnico.

Forster \& Culshaw (1990 apud Pires Neto 1994) propõem para trabalhos de mapeamento geotécnico quatro tipos de mapas:

- Mapas Factuais - apresentam informações básicas.

- Mapas Interpretativos - apresentam zoneamento quanto ao grau de risco, usos específicos e preferenciais.

- Mapas de Único Propósito - mostram informações relevantes de um único aspecto para construção ou desenvolvimento.

- Mapas de Múltiplos Propósitos - onde estão representados os diferentes fatores geológicos necessários ao planejamento regional. Estes mapas apresen- 
tam dificuldades de elaboração, pois podem ser ilegíveis devido a enorme quantidade de informações que possam conter.

Em relação a escala do mapa, estes autores consideram: Mapas de Detalhe (entre 1:50.000 e 1:5.000) - indicados para estudos especificos ou riscos e necessários para construções, implementação de loteamentos e planejamento de cidades; Mapas Regionais (1:50.000 ou menores) - para planejamento.

Quanto à água subterrânea, os autores propõem a análise das características dos aqüiferos e de seu potencial de contaminação para ser usado nos estudos de planejamento territorial.

Em seu trabalho, Zonneveld (1992) apresenta o conceito da Ciência da Paisagem ou Ecologia da Paisagem como sendo o embasamento científico que substitui a avaliação prática da terra. Em planejamento, no entanto, a promoção de "desenvolvimentos favoráveis, mantendo uma situação ótima e um mínimo de efeitos negativos na terra", demanda uma grande variedade de pesquisas a diversas escalas e de análise e síntese, onde várias disciplinas estão envolvidas. A Ecologia da Paisagem ou levantamento de unidades de terreno pode envolver estudos de diversas áreas do conhecimento (como solos, vegetação, clima, hidrologia e geomorfologia) para cumprir a finalidade do planejamento, pois apresenta resultados diretos das delimitações das unidades de terreno, que pode ser usado diretamente como base para esta avaliação da terra.

No conceito da Ecologia da Paisagem, uma região (ou paisagem) é considerada uma entidade holistica e dinâmica, com níveis hierárquicos identificáveis que podem ser classificados e mapeados. Os "atributos do terreno" são definidos como os elementos físicos ou biológicos que compõem a paisagem e estão intensamente interrelacionados, formando um complexo tridimensional de reconhecimento visual por apresentar um padrão horizontal característicos, considerando a heterogeneidade vertical formado por todos os atributos do terreno. Quanto à operacionalidade da metodologia, o conceito da paisagem apresenta maior compreensão do terreno e rapidez de execução (ou maior economia no levantamento). As unidades de terreno são mapeadas e classificadas de acordo com a hierarquia e seus atributos, por meio de observações gerais e superficiais (embasados nos conhecimentos de trabalhos anteriores mais aprofundados). Com este levantamento geral é possivel determinar o funci- 
onamento de um sistema onde o diagnóstico de certos comportamentos de terreno são caracteristicos de uma unidade de terreno delimitada.

O "Guia para la elaboración de estudios del medio físico: contenido y metodologia" de Farias et alii (1994) traz todos os procedimentos necessários para efetuar estudos do meio físico para planejamento e desenvolvimento de um território. Neste guia, os autores admitem a complexidade e diversidade destes estudos e que por isso a visão do meio físico em sua totalidade é dificultosa, resultando muitas vezes em enfoques parciais.

"O estudo do meio físico deve proporcionar e elaborar a informação necessária para a tomada de decisões, relativa a distribuição dos usos do solo." Não há uma metodologia universal aplicável em qualquer tipo de território, porém se conhece que o desenvolvimento deste estudo exige a execução de uma série de etapas sucessivas, que se inicia com a escolha da escala de trabalho e finaliza com a classificação e caracterização do território, de acordo com as finalidades propostas.

Em suma, os procedimentos consistem da elaboração do inventário dos elementos do meio físico necessários e posteriormente na análise de integração das informações. Essa integração visa avaliar o meio natural, pois os elementos que o compõem se apresenta organizado, constituindo-se em um sistema (que é um conjunto de elementos e relações que se interconexam), como também as respostas deste à ações externas naturais ou antrópicas.

O entendimento da dinâmica e dos sistemas naturais implica em interpretação dos dados e consequentemente na aplicação de modelos e técnicas de análise das informaçōes contidas no inventário, resultando em uma sintese. As técnicas comumente empregadas para este fim consistem no estabelecimento de prioridades, ponderação, superposição manual de mapas, tratamento automático, análises multivariadas.

Os procedimentos para execução de estudos do meio físico são detalhadamente descritos, onde as metodologias aplicadas de diversos campos do conhecimento (geologia, geomorfologia, clima, solo, água, vegetação, fauna, recursos culturais, paisagem e processos e riscos) estão contidos no guia.

Seignemartin (1979) apresenta o histórico dos trabalhos de geologia ambiental e de planejamento no Brasil. Na década de 70 , segundo esse autor, os primeiros tra- 
balhos discutem a importância da geologia na participação nos processos de planejamento territorial e urbano. Em seguida, os trabalhos já denotam preocupações e tentativas de criação de uma metodologia nacional e aplicações em áreas especificas, com o intuito de indicar diretrizes para a ocupação do meio físico. A questão de adaptar e desenvolver metodologias para países como o Brasil tem continuidade.

A tese de doutoramento de Seignamartin (1979) desenvolve o tema Geologia de Áreas Urbanas, aplicando seus estudos no centro urbano do municipio de Ribeirão Preto. O autor analisa diversos conceitos como planejamento e geologia ambiental, introduzindo a expressão Geologia de Áreas Urbanas, bem como as diversas correntes metodológicas da cartografia geológico-geotécnica. A metodologia seguida neste trabalho é a de Sanejouand (1972).

As cartas geotécnicas elaboradas pelo Instituto de Pesquisas Tecnológicas (IPT), entre o periodo de 1973 a 1991, foram elaboradas a partir das problemáticas de maior relevância na área de investigação, dirigidas a problemas especificos, sendo cartas de susceptibilidade e de riscos geológicos.

Dentre os diversos trabalhos acadêmico-científicos de universidades referentes à geologia ambiental e estudos geológico-geotécnicos, destacam-se Duarte (1980), Cottas (1983), Gonçalves (1986), Taveira (1986 apud Souza 1992), Zuquette (1987), Carvalho (1987 apud Souza op cit.), com estudos no município de Ouro Preto, Pejon (1987 apud Souza op.cit.), em Araraquara, Vecchiato (1987 apud Souza op.cit.), em Curitiba, e Giusti (1989), sobre a aplicação da cartografia geotécnica em planejamento de regiões ou municípios em franco desenvolvimento.

O estudo executado por Duarte (1980) é um dos primeiros trabalhos de geologia ambiental desenvolvidos no Brasil. O tema águas subterrâneas é desenvolvido sob o enfoque geoambiental e o trabalho apresenta um diagnóstico com a caracterização do potencial do recurso e de sua vulnerabilidade natural na região de São Pedro - SP.

O método adotado é baseado na proposta de Matheson \& Font (1974). Os resultados consistem de uma série de documentos relativos a problemas de geologia ambiental e tem como base a preservação das águas subterrâneas. Os mapas resultantes deste estudo focam a geologia, hidrogeologia, qualidade das águas, características dos materiais de cobertura, declividade, vulnerabilidade e potencial de uso. $O$ 
vetor águas subterrâneas seria o parâmetro mais relevante a ser pesado nesta avaliação de potencial de uso.

Cottas (1983) apresenta um estudo geológico-geotécnico voltado ao planejamento, e executado no município de Rio Claro - SP. O método desenvolvido pretendeu buscar uma abordagem mais abrangente dos problemas geológicos referentes ao planejamento urbano, de modo que sua aplicabilidade não tivesse caráter estritamente loćal.

O autor desenvolveu seguintes estudos relativos à água subterrânea: determinação das profundidades dö nível freático, potenciometria dos aqüiferos e qualidade das águas superficiais e subterrâneas, sendo que os dois primeiros estão representados por mapas. Estes tipos de análise hidrogeológica, bem como os demais tipos de estudos citados, são essencialmente voltados às obras de engenharia, abrangendo apenas a parte urbana do municipio. Os mapas resultantes deste estudo foram apresentados em escala 1:20.000.

Gonçalves (1986) apresenta estudos de geologia ambiental no município de São Carlos, caracterizando a área em seus aspectos geológicos, pedológicos e geotécnicos. As informações do meio físico, do uso atual da terra e das fontes de poluição foram, então, interrelacionadas, objetivando "solucionar, prever, sugerir, melhorar e proteger" o meio ambiente do município, uma vez que os problemas e seus condicionantes estão detectados. Com relação à água subterrânea, o autor determina a direção de fluxo, a superfície freática e o "freático confinado", e a vulnerabilidade potencial da área, por meio de dados de geologia local e permeabilidade. Por fim, o autor levanta a necessidade de conscientização por meio de trabalhos como este à administração pública.

Zuquette (1987) discute em seu trabalho as metodologias de cartografia geotécnica existente e apresenta uma proposta para países em desenvolvimento, como o Brasil, em que há falta de informações básicas e documentadas. O autor apresenta três categorias de mapas finais, de acordo com o escopo do trabalho; os mapas de condições geotécnicas, que representam as características dos atributos do meio físico, sem a influência dos usos da terra, executados nas escalas menores que 1:100.000; os mapas de Zoneamento Geotécnico Geral, representam as condições do meio físico, por meio de zonas que tenham condições geotécnicas similares, não considerando alguma finalidade especifica. Por fim, na terceira categoria, encontram- 
se os mapas de zoneamento geotécnico especifico, executado nas escalas maiores que 1:50.000 e apresentam zoneamento de áreas com condições geotécnicas necessárias a uma determinada atividade ou problema.

Giusti (1989) executa no municipio de Curitiba - PR um levantamento geológico, estudos geofísicos e hidrogeológicos objetivando fornecer bases físicas para o planejamento da ocupação urbana e industrial da cidade.

Maciel Filho (1990) elabora a "Carta Geotécnica de Santa Maria", na escala 1:50.000, seguindo basicamente a metodologia da publicação da UNESCOVAEG (1976) "Engineering geological maps - a guide to their preparation". O trabalho está organizado em duas cartas com textos explicativos: a carta das unidades geotécnicas e carta de zoneamento dos condicionantes à ocupação. A primeira apresenta os condicionantes hidrogeológicos e de materiais de subsuperficie que podem influenciar no uso do solo; a segunda carta é uma síntese em termos de recomendações gerais de uso.

Os estudos hidrogeológicos objetivaram a determinação da potencialidade como recurso hídrico e de sua vulnerabilidade a contaminação, e aos possiveis problemas geotécnicos que possam ocorrer devido a algumas condições peculiares locais das águas subterrâneas.

A carta de unidades geotécnicas apresenta o sentido provável de fluxo das águas subterrâneas, o comportamento hidrogeológico das rochas, classificando-as em aqüifero, aqüitardo e aqüicludes, e a delimitação do contato entre unidades com possíveis ocorrências de fontes. No texto explicativo, cada unidade geotécnica possui descrição suscinta do comportamento hidrogeológico, situação e importância da água subterrânea na região.

Souza (1992) utilizou o sistema de análise de terreno P.U.C.E., em que a compartimentação do meio físico utilizada foi a geomorfológica, caracterizados por meio de perfis típicos de alteração. A escala deste estudo, 1:50.000, definiu as Unidades de Terreno, avaliada em função de sua susceptibilidade a riscos naturais (hazards), viabilidade de uso e ocupação, e aptidão a recursos. Quanto ao tema águas subterrâneas, a autora se baseia nos trabalhos regionais existentes (Torres \& Mezzalira 1977 apud Souza op. cit., DAEE 1981, Diogo et al. 1981), onde delimitaçōes dos aqüiferos locais se encontram representados na Carta de Recursos Hídricos. As informações hidrogeológicas foram aplicadas na avaliação da potencialidade/conservação dos re- 
cursos naturais. Assim, em cada unidade de terreno, encontra-se descrita sinteticamente a potencialidade e susceptibilidade do aqüífero. A área de estudo foi a região de Aguai.

$\mathrm{Na}$ tese de livre docência, Zuquette (1993) realiza uma avaliação global da cartografia geológico-geotécnica, desde sua importância para o planejamento territorial e avaliação ambiental a nível internacional e nacional até chegar a uma proposta de eĺaboração de mapeamento geotécnico para condições brasileiras.

Atualmente, diversos órgãos federais e estaduais desenvolvem estudos do meio físico voltados ao planejamento de municipios, principalmente em áreas com problemas de adensamento populacional.

Os estudos do Instituto Geológico dirigidos ao planejamento de uso e ocupação do solo em municípios encontram-se no Programa "Cartas Geológicas e Geotécnicas para o Planejamento Ambiental entre Sorocaba e Campinas", onde foram desenvolvidos trabalhos nos municipios de Sorocaba (IG 1990), Itu (1991) e finalizando com Campinas (1993). Em seguida, iniciam-se estudos na Bacia Hidrográfica do Rio Piracicaba, especificamente em oito municípios (Holambra, Jaguariúna, Sumaré, Paulinia, Nova Odessa, Americana, Cosmópolis e Hortolândia), limítrofes a Campinas (IG 1995).

O método aplicado, definido por Mabbut (1968 apud Pires Neto, Brollo \& Yoshinaga 1995) como paramétrico, consistiu primeiramente, em avaliações individuais das seguintes áreas do conhecimento: geologia e geomorfologia, que forneceram a base para os estudos aplicados de geotecnia, recursos minerais e hidrogeologia. A sistemática de integração das informaçōes evoluiu e se modificou; inicialmente aplicou-se o conceito de Unidades Homogêneas (IG 1990), passando a Unidadesde Terreno (IG 1991) e Tipos de Terreno (IG1993). Em IG (1995), o mapa síntese das informações do meio físico (relevo, substrato rochoso, solo, água subterrânea e clima) consistiu no Mapa Diagnóstico do Meio Físico, cujas unidades foram baseadas nas unidades dos materiais inconsolidados e na abordagem geológico-geotécnica (Pires Neto, Brollo \& Yoshinaga 1995).

Os estudos hidrogeológicos executados para o planejamento territorial e análise ambiental, consistiram basicamente em avaliações hidrogeológicas regionais, de caracterização hidrodinâmica dos Sistemas Aqüiferos, potencialidade e reservação dos recursos, vulnerabilidade natural dos aqüiferos à contaminação e uso e demanda 
da água subterrânea. Em Campinas (IG 1993), foi realizado um estudo de detalhe sobre a contaminação poço-fossa em áreas favelizadas e no projeto "da Porção Média do rio Piracicaba", elaborou-se a "Carta Orientativa ao Usuário da Água Subterrânea".

Os estudos elaborados pela EMPLASA (1993) sobre metropolização englobam avaliações de ordem física, social e de uso e ocupação do solo, visando apontar os "impactos resultantes do uso da terra, bem como subsidiar futuros Planos de Desenvolvimentos para a Região de Campinas - Área de Metropolização, composta por 18 municípios.

A carta sintese, resultado da análise integrada destas informações levantadas, foi feita com base na análise morfodinâmica, considerando que o ambiente "não é estático nem imutável", e com a intervenção do homem o processo natural de alteração do meio natural é acelerado. Os termos estabilidade (ou equilíbrio morfodinâmico) e instabilidade foram aplicados para o zoneamento ambiental, de acordo com o padrão de vulnerabilidade ambiental.

A Companhia de Pesquisa e Recursos Minerais (CPRM) está executando projetos para subsidiar com informações do mejo físico as prefeituras e os governos estaduais, no planejamento territorial, preservação do ambiente e racionalização dos recursos naturais. Os projetos foram realizados em Porto Alegre - RS (do Programa PROTEGER), Curitiba - PR, Recife - PE (SINGRES), entornos de Belo Horizonte MG (VIDA). No Programa PROTEGER, a CPRM conjuntamente com a METROPLAN, desenvolveram cartas temáticas em municípios da Região Metropolitana de Porto Alegre, como Estância Velha e Bacia do rio Gravatai. O método de estudo consiste no levantamento das informações básicas como declividade, geomorfologia, cobertura vegetal e ocupação atual do solo, capacidade do solo para fins agricolas, pedologia, adequação do uso agrícola, susceptibilidade à erosão, geologia, formação superficial, cadastramento mineral, linhas de cheias, cadastramento hidrogeológico, hidrogeologia, vulnerabilidade de aqüiferos. As cartas intermediárias, resultantes do cruzamento dos mapas básicos resultam em áreas naturais para proteção, no potencial agrícola, potencial mineral, áreas de risco potencial e potencial hidrogeológico. A carta síntese resulta na carta de aptidão do uso do solo para esta bacia (CPRM 1994, Orlandino Filho \& Giugno 1993). 
Em Curitiba (CPRM 1994), o projeto desenvolvido por esta empresa objetivou em "fornecer aos administradores e planejadores informações integradas sobre as principais características do meio físico e suas respostas frente às várias formas de uso e ocupação". A compartimentação do meio físico baseou-se na associação entre as características litológicas, geomorfológicas e estruturais, definindo dominios morfolitostruturais, e em subdomínios, em função de certas peculiaridades observadas ' nestes arranjos de determinados atributos. A escala de trabalho foi 1:100.000. As cartas de drenagem, de densidade de drenagem, de densidade de lineações em série, de tropia, de padrões de relevo de formas cársticas e morfolitostrutural e de uso e ocupação do solo são os produtos desta primeira fase deste projeto. 


\subsection{MÉTODO APLICADO}

O método de estudo consistiu no cumprimento de etapas de trabalho, comuns ao desenvolvimento de projetos de pesquisa, sendo essas: revisão da bibliografia referente ao tema abordado e à área de estudo, trabalhos de campo e tratamento e análise das informações levantadas.

\subsubsection{Levantamento das informações Existentes}

As informações utilizadas para a execução do trabalho consistiram na análise dos seguintes temas, concernentes:

- à temática do trabalho - consistiu em realizar um levantamento da bibliografia nacional e internacional relativo aos estudos de avaliações hidrogeológicas regionais, levantamento hidrogeológico sistemático e cartografia hidrogeológica, visando analisar o desenvolvimento desses estudos e suas tendências, em paises de primeiro mundo e a situação no Brasil, especificamente no estado de São Paulo. Ainda dentro desse assunto, atenção foi dada à evolução das cartas de síntese hidrogeológica para subsidiar estudos de planejamento e meio ambiente. Nessa fase ainda, os levantamentos de estudos integrados do meio físico, de geomorfologia e de geotecnia para efeitos de planejamento (urbano e territorial) foram analisados também, no sentido de se avaliar as diversas técnicas de estudos existentes para esse fim, como também em se verificar a importância da água subterrânea no planejamento, a sua importância nessas áreas espécíficas do conhecimento (geotecnia e geomorfologia) e o grau de desenvolvimento da análise da água subterrânea como atributo/recurso para esses tipos de estudo. Essa análise fundamentou a elaboração de técnicas de tratamento e interpretação dos dados.

- à área de estudo - toda a bibliografia referente à caracterização do meio físico, sócio-economia e uso e ocupação do solo foram analisados, no sentido de se obter um diagnóstico da área de trabalho. Os assuntos abordados, objetos da análise, foram relativos à evolução sócio-econômica, à geologia, à geomorfologia e ao clima, geotecnia, pedologia e hidrogeologia.

Os mapas geológico e geomorfológico usados nesse estudo foram compilados com base na bibliografia existente, em escala 1:100.000. 
-cadastramento de poços tubulares profundos - foi desenvolvida em duas etapas distintas de trabalho: primeiramente, executou-se o cadastramento de poços com visitas ao Departamento de Águas e Energia Elétrica, aos Serviços Municipais de Água e Esgoto (SAEE's e SAMAE's) e às empresas de perfuração de poços tubulares profundos. Na segunda etapa, os trabalhos de campo foram executados no sentido de complementar e locar os poços cadastrados, assim como em levantar novos 'poços', em mapas de escala 1:10.000. Nos municipios de Campinas, Jaguariúna, Holambra, Cosmópolis, Paulinia e Nova Odessa, o cadastramento de campo foi executado de forma completa. Em Americana, Sumaré e Hortolândia esse tipo de cadastramento não foi executado, pois haviam dados organizados nas prefeituras. Nos 'municipios de Santa Bárbara d'Oeste, Engenheiro Coelho, Valinhos, Vinhedo, Monte Mor, Pedreira, Santo Antonio da Posse os dados utilizados foram do levantamento executado pelo DAEE (1981).

As informações obtidas foram colocadas em fichas e então inseridas no banco de dados SIPO, desenvolvido por Oda (1996, mim.), em linguagem DBASE Plus e Clipper.

$\mathrm{Na}$ área de estudo, foram cadastrados 1711 poços tubulares profundos, onde 1008 possuem dados hidrodinâmicos (leia-se nível estático, nível dinâmico e vazão), 1217 com perfis geológicos, 1684 com informações sobre o uso da água subterrânea, $10 \mathrm{com}$ testes de bombeamento.

\subsubsection{Processamento e Análise das Informações}

Os estudos desenvolvidos neste trabalho abordaram diversos temas, que tiveram procedimentos de tratamento de dados específicos para cada tipo de análise executada. Porém, a interpretação dos resultados foram integradas, onde a análise de cada tema corroborou, reforçou, ou apresentou resultados e conclusões inéditos.

No tratamento das informações e elaboração final dos resultados, foram utilizados os softwares da Microsoft: Excel, Word, Surfer, AutoCAD e DBASE Plus. Para o cálculo da transmissividade de testes de bombeamento existentes, foi utilizado o cálculo de Cooper-Jacob pelo programa TESTBOMB, de autoria de Bottura (mim).

A seguir, os procedimentos de análise de cada tema desenvolvidos são descritos neste estudo. 


\section{CARACTERIZAÇÃO DO MEIO FÍSICO E CLIMATOLOGIA:}

- Geologia e geomorfologia - uso da bibliografia e mapeamentos existentes à diversas escalas e compilação cartográfica na escala 1:100.000. A análise integrada destas ciências resultou em um primeiro diagnóstico do meio físico da área de estudo. O mapa sintese, por Sistemas de Terreno, representa esta integração e suas interrelações.

- Hidroclimatologia e Balanço Hidrico - o objetivo desse estudo, é a obtenção da classificação climática geográfica definindo unidades climáticas homogêneas, associando isso ao ciclo hidrológico como um todo, ou seja, incluindo a água subterrânea para aprofundamento do conhecimento científico sobre a questão fornecendo subsídios para o planejamento.

O método utilizado para a definição das unidades climáticas é fundamentado nas concepções do Geógrafo Carlos Augusto de Figueredo Monteiro, principalmente na obra -"A dinâmica climática e as chuvas no Estado de São Paulo (1973)". Essa metodologia abrange a dinâmica pluviométrica interativa aos Ambientes Bio-GeoFisico e aos controles pluviométricos, assinalando variações no espaço e no tempo.

Para alcançar esse objetivo, utilizaram-se 31 postos pluviométricos operados pelo DAEE (Tabela 3) em um período de 15 anos distribuidos pela área de estudo e seu entorno. O critério de escolha desse periodo se baseou na existência de poucas falhas nos dados, pois observou-se que, quanto maior era o periodo de observação, menos postos poderiam ser utilizados, resultando em áreas sem qualquer tipo de informação. De posse das informações pluviométricas foram feitos vários mapas de chuvas, bem como transectos temporo-espaciais de chuvas, em um perfil, grosso modo, ENE-WSW (ver mapa de unidades climáticas) que são detalhados em suas análises.

As informações relativas as temperaturas médias mensais foram obtidas pelas tabelas que correlacionam temperaturas com a altitude e a latitude, elaboradas por pesquisadores do IAC (Instituto Agronômico de Campinas - SP), o que vem de encontro com as recomendações da WMO (World Meterological Organization - Guide to Climatological Practices 1983), para a utilização de dados estimados em áreas onde a cobertura de informações são incipientes (como é o caso). 
Foi possivel, com as informações de chuvas e temperaturas, através do Software Balasc (desenvolvido por pesquisadores do CEPAGRI/ UNICAMP/SP) elaborar o Balanço Hídrico pelo método de THORNTWHAITE \& MATHER (1955) para toda a área. Esse método propiciou o conhecimento principalmente da evapotranspiração potencial, excedentes e deficiências hídricas que foram fundamentais para a distinção de feições climáticas e as células climáticas de maior afinidades.

Salienta-se que todas as informações foram interpoladas manualmente, em um mapa escala 1:100.000, considerando-se suas interações com os fatores geográficos (relevo e disposição das vertentes em relação aos fluxos atmosféricos mais importantes).

Foram feitos também transectos temporo-espaciais em um perfil, grosso modo, ENE - WSW (ver mapa das unidades climáticas), da evapotranspiração potencial, dos excedentes e deficiências hídricas. O objetivo mais amplo da confecção desses transectos temporo-espaciais, tanto de chuva como dos resultados do balanço hídrico foram dar maior consistência a determinação das feições e das células climáticas, pois nesse perfil encontram-se, via de regra, os extremos, ou seja os maiores e os menores valores dos elementos climáticos analisados. 
Tabela 3 - Postos Pluviométricos Utilizados No Estudo

\begin{tabular}{|l|l|l|l|l|}
\hline CODIGO & \multicolumn{1}{|c|}{ MUNICIPIO } & LATITUDE & LONGITUDE & $\begin{array}{l}\text { ALTITUDE } \\
\text { (M) }\end{array}$ \\
\hline D4-004 & AMERICANA & 2242 & 4717 & 540 \\
\hline D3-023 & AMPARO & 2243 & 4650 & 660 \\
\hline D4-099 & ARTUR NOGUEIRA & 2234 & 4710 & 640 \\
\hline D4-046 & CAMPINAS & 2247 & 4702 & 600 \\
\hline D4-047 & CAMPINAS & 2250 & 4704 & 630 \\
\hline D4-044 & CAMPINAS & 2253 & 4705 & 710 \\
\hline D3-002 & CAMPINAS & 2256 & 4654 & 690 \\
\hline D4-011 & CAMPINAS & 2258 & 4708 & 620 \\
\hline E4-123 & CAMPINAS & 2301 & 4706 & 640 \\
\hline D4-092 & CAPIVARI & 2253 & 4727 & 570 \\
\hline D4-069 & CAPIVARI & 2300 & 4730 & 500 \\
\hline D4-052 & COSMOPOLIS & 2240 & 4713 & 560 \\
\hline E4-013 & ELIAS FAUSTO & 2302 & 4722 & 580 \\
\hline E4-119 & ELIAS FAUSTO & 2306 & 4725 & 660 \\
\hline E4-015 & INDAIATUBA & 2305 & 4713 & 630 \\
\hline E4-124 & INDAIATUBA & 2310 & 4708 & 700 \\
\hline E3-015 & ITATIBA & 2301 & 4650 & 780 \\
\hline E4-062 & ITUPEVA & 2305 & 4703 & 690 \\
\hline D4-082 & JAGUARIUNA & 2238 & 4703 & 600 \\
\hline E3-053 & JUNDIAI & 2312 & 4659 & 730 \\
\hline D4-064 & LIMEIRA & 2234 & 4722 & 640 \\
\hline D4-100 & MOJI-GUACSU & 2217 & 4709 & 580 \\
\hline D4-083 & MONTE MOR & 2256 & 4715 & 610 \\
\hline D3-052 & PEDREIRA & 2245 & 4656 & 590 \\
\hline D4-103 & PIRACICABA & 2234 & 4736 & 590 \\
\hline D4-104 & PIRACICABA & 2243 & 4739 & 500 \\
\hline D4-102 & PIRACICABA & 2245 & 4731 & 510 \\
\hline D4-068 & RIO DAS PEDRAS & 2252 & 4737 & 615 \\
\hline D4-088 & STA BARBARA D'OESTE & 2245 & 4727 & 540 \\
\hline D4-079 & STA BARBARA D'OESTE & 2249 & 4728 & 600 \\
\hline E3-017 & VINHEDO & 2302 & 4658 & 700 \\
\hline
\end{tabular}




\section{ÁGUA SUBTERRÂNEA:}

- Geometria dos sistemas aqüiferos - a base geológica, a bibliografia existente e o inventário de poços tubulares profundos (especificamente dados dos perfis geológicos do poços) são usados para a caracterização tridimensional dos aqüiferos, com a confecção de mapas de isoespessuras de sedimentos (arenitos e siltitos/argilitos), contorno estrutural do embasamento cristalino e espessura do manto de alteração e ocorrências de diabásios em subsuperfície.

- Circulação das águas subterrâneas - é avaliada com base nos dados de nível estático dos poços tubulares profundos cadastrados e na topografia do terreno.

- As curvas eqüipotenciais são delineadas considerando-se os dados de nível estático e assim, as áreas de recarga e descarga locais são determinados.

- Caracterização hidrodinâmica e análise da produtividade - os parâmetros utilizados para a caracterização hidrodinâmica foram a capacidade específica $\left(\mathrm{m}^{3} / \mathrm{h}\right.$ por metro de rebaixamento), a transmissividade $\left(\mathrm{m}^{2} / \mathrm{dia}\right)$, e a vazão dos poços. Os sistemas aqüíferos avaliados foram o Tubarão, o Cristalino, os Diabásios e os poços mistos, que exploram mais de um aqüifero. A produtividade dos poços foram relacionados com as litologias e estruturas, determinando-se seus fatores condicionantes. $A$ análise de parâmetros hidrodinâmicos para a caracterização das condições de ocorrência das águas subterrâneas nos sistemas aqüiferos locais teve tratamento estatístico dos dados de capacidade especifica determinando-se a mediana de cada sistema aqüifero.

No aqüifero sedimentar, as medianas de capacidade especifica de poços com perfis que possuem arenito (em \%) são correlacionados. O mapa de isovalores da porcentagem de arenito nos perfis de poços será sobreposto a um mapa de capacidades específicas, no intuito de determinar zonas de maior potencialidade de produção.

A caracterização da produtividade dos poços em função da litologia sedimentar aflorante também é avaliada, bem como as feições geomórficas, como vales e grandes lineamentos determinados pela rede de drenagem obtidas em mapas topográficos de escala 1:50.000 e imagem de satélite, na escala 1:100.000.

No aqǘfero diabásio, os procedimentos de análise hidrodinâmica consistem de caracterizar inicialmente a mediana da capacidade específica dos poços, e verificar a 
importância da feição geomórfica vale e dos lineamentos de fraturas na produtividade.

No aqüífero cristalino, o método utilizado é similar ao aqüiffero diabásio, incluindo a análise estatística de capacidade especifica por litologias e a distribuição das freqüências dos valores médios dos poços em relação a direção dos lineamentos de fratura. A espacialização e zoneamento dessas produtividades são baseados essencialmente na geologia estrutural da área.

Os poços mistos são analisados estatisticamente e separadamente, pois as produtividades podem estar correlacionadas justamente com a combinação dos vários sistemas aqüíferos ou de seus contatos. Alguns procedimentos indicados para a análise do aqüífero sedimentar, cristalino e diabásio serão adotados, dependendo da ocorrência destas formações nos perfis geológicos em poços tubulares.

As tendências de distribuição da produtividade são determinadas e analisadas sob o enfoque das litologias predominantes, da espessura do pacote sedimentar e das grandes estruturações existentes na área.

Os resultados das avaliações das produtividades de cada sistema aqüifero produzirão as bases para a elaboração do mapa de zonas de produtividade de água subterrânea. Estas zonas serão delineadas mediante a criação de modelos de armazenamento e condutibilidade da água subterrânea, que envolverá outros critérios como: direção de fluxo e a geometria dos aqüíferos.

- Estimativa da disponibilidade de água subterrânea - os procedimentos do cálculo da disponibilidade de água subterrânea foram baseados pelo método proposto por Lopes (1994). O cálculo do volume de água subterrânea disponível é realizada pela seguinte expressão, adotada por IG (1993) para o municipio de Campinas:

$$
\text { Qdisponivel }=S \cdot Q_{7,10} \cdot f \text {, onde: }
$$

$Q=$ vazão em metros cúbicos de água disponível por unidade de tempo em segundos.

$\mathrm{S}=$ área de recarga em quilômetros quadrados

$Q_{7,10}=$ vazão mínima anual específica de 7 dias para o período de recorrência de 10 anos, que equivale aos valores de recarga transitória multianual do aqüífero. $\dot{E}$ a quantidade média de água que passa pelo aqüifero a partir de precipitação e consti- 
tui o escoamento básico do sistema de drenagem superficial da área considerada (em metros cúbico por segundo por quilômetro quadrado).

$f=$ fator percentual que representa a quantidade máxima de água possivel de ser explorada a partir da recarga devido a fatores técnicos e hidrogeológicos limitantes. Esse valor varia empiricamente entre 0,2 (rochas fraturadas - aqüiferos Cristalino e Diabásios) e 0,25 (rochas sedimentares - aqüiferos Itararé e Cenozóico).

Essa vazão disponivel é considerada a Reserva Ativa de água do aqüifero, ou seja, o volume de água infiltrado para o aqüifero por precipitação em uma sub-bacia que atua diretamente no escoamento básico de corpos de água superficial. Em outras palavras, é o volume de água situado entre a superficie potenciométrica e o nivel de base de uma drenagem de dada região, e que vem a constituir no potencial renovável de água subterrânea de uma bacia (Lopes 1994).

A área de estudo foi dividida de acordo com as sub-bacias que compõem as Bacias dos rios Piracicaba, Capivari e Tietê, e os dados de escoamento básico foram obtidos pela análise hidrológica de dados provenientes de postos fluviométricos, possuidores de controle e série hístórica compativel, por DAEE (1980).

A disponibilidade foi calculada também por sistemas aqüiferos Tubarão, Cristalino, Diabásio e Cenozóico.

Nesta disponibilidade, é adicionada uma porcentagem de $17 \%$ do volume total de água tratada e distribuída, correspondente às perdas na rede de distribuição, e onde parte se infiltra para a água subterrânea.

A perda de água na rede de distribuição varia de 10 a $25 \%$, dependentes da situação em cada município; para esse estudo considerou-se a média de $17 \%$ para o cálculo. Essa média foi aplicada em seu total, apesar da ciência de que parte dessa perda se infiltra para a água subterrânea; porém, é sabido das perdas não computadas por nenhum órgão de redes de águas pluviais ou de esgoto; assim, grosso modo, considera-se esse valor total como estimativa.

- Consumo de água subterrânea - a estimativa do consumo é baseada em IG (1995) e Lopes (1994), pela seguinte expressão:

CONSUMO $=Q z$. Npoços. Tbomb/24, onde: 
CONSUMO $=$ volume total em metros cúbicos por tempo em segundos de água subterrânea explotada pelos poços do municipio

$\mathrm{Qz}=$ vazão média $\left(\mathrm{m}^{3} / \mathrm{s}\right)$ dos poços da área de estudo $\left(6,0 \mathrm{~m}^{3} / \mathrm{h}\right)$

Npoços = número total de poços em funcionamento na área de estudo

Tbomb $=$ tempo de bombeamento médio em horas por dia, ponderado pelo tipo , de uso da água (9 horas por dia)

O número de poços da área de estudo foi baseada em estimativas calculadas por IG(1993, 1995) e Lopes (1994), para o ano de 1994 (data de fechamento do cadastro de poços).

A estimativa do consumo é calculada para diversas atividades econômicas região, cruzados com os dados de disponibilidade de água subterrânea, visando a obtenção de um quadro atual da situação e perspectivas. Os valores em porcentagem do número de poços utilizados por tipo de atividade econômica (primário, secundário e terciário) e pelo abastecimento público e particulares são determinados com base nos números existentes no cadastro (Tabela 4). Os valores produzidos são usados para estimar o número de poços, o consumo por atividade econômica e por fim, o consumo total de água subterrânea na área de estudo. Para cada setor, o tempo de bombeamento atribuido é: primário - $8 \mathrm{~h} /$ dia; secundário - 18h/dia; terciário - $6 \mathrm{~h} / \mathrm{dia}$; abastecimento público $-24 \mathrm{~h} / \mathrm{dia}$ e particulares $-2 \mathrm{~h} / \mathrm{dia}$.

O consumo per capita (estimado em $300 \mathrm{l} / \mathrm{dia}$ ) resulta em um total estimativo de água superficial para o cálculo das perdas da rede de distribuição, considerando que $90 \%$ da população total da área de estudo é abastecida por água e esgoto. $A$ Região Metropolitana de Campinas possui uma população total de 1.912 .782 habitantes; o consumo de água estimado é de $6,0 \mathrm{~m}^{3} / \mathrm{s}$, considerando $90 \%$ da população abastecida por água superficial. Assim, a perda calculada é de $1,02 \mathrm{~m}^{3} / \mathrm{s}$ ou $3,2 \mathrm{mi}$ Ihões de metros cúbicos por ano. 
Tabela 4 - Estimativa de uso de poços tubulares profundos por atividade económica na Região Metropolitana de Campinas - SP.

\begin{tabular}{|c|c|c|c|c|c|c|c|c|c|}
\hline MUNICIPIO & $\begin{array}{c}\text { POPULAÇÃO } \\
\text { (hab.) }\end{array}$ & $\begin{array}{l}\mathrm{N}^{\circ} \text { POÇOS } \\
\text { EXISTENTES }\end{array}$ & $\begin{array}{l}N^{\circ} \text { POÇOS } \\
\text { ESTIMADOS }\end{array}$ & $\begin{array}{c}\text { PRIMÁRIO } \\
\text { AGROPECUÁ- } \\
\text { RIA }\end{array}$ & $\begin{array}{l}\text { PRIMÁRIO } \\
\text { MINERAÇĀo }\end{array}$ & $\begin{array}{l}\text { SECUNDÁRIO } \\
\text { INDÚSTRIA }\end{array}$ & $\begin{array}{l}\text { TERCIÁRIO } \\
\text { COMÉRCIO }\end{array}$ & $\begin{array}{l}\text { PARTICULAR } \\
s\end{array}$ & $\begin{array}{c}\text { ABASTECIME } \\
\text { TO }\end{array}$ \\
\hline CAMPINAS & 873612 & 672 & 806 & 137 & 8 & 209 & 137 & 217 & 98 \\
\hline VINHEDO & 35844 & 27 & 110 & 26 & 5 & 37 & 0 & 37 & 5 \\
\hline MONTE MOR & 27976 & 36 & 182 & 60 & 0 & 36 & 5 & 76 & 5 \\
\hline VALINHOS & 71166 & 126 & 363 & 51 & 0 & 77 & 29 & 181 & 25 \\
\hline INDAIATUBA & 110515 & 43 & 168 & 39 & 0 & 32 & 3 & 94 & 0 \\
\hline PEDREIRA & 28791 & 15 & 45 & 9 & 40 & 3 & 0 & 12 & 3 \\
\hline $\begin{array}{l}\text { S. BARBARA } \\
\text { OESTE }\end{array}$ & 160582 & 42 & 105 & 5 & 0 & 30 & 0 & 35 & 35 \\
\hline $\begin{array}{c}\text { ARTUR } \\
\text { NOGUEIRA ENG. } \\
\text { COELHO } \\
\end{array}$ & 21045 & 13 & 70 & 27 & 0 & 6 & 10 & 10 & 17 \\
\hline $\begin{array}{c}\text { SANTONIO } \\
\text { POSSE }\end{array}$ & 14828 & 7 & 28 & 4 & 0 & 4 & 0 & 20 & 0 \\
\hline AMERICANA & 158526 & 106 & 120 & 1 & 0 & 47 & 11 & 56 & 5 \\
\hline NOVA ODESSA & 36484 & 56 & 60 & 5 & 1 & 34 & 5 & 11 & 4 \\
\hline SUMARE & 157887 & 101 & 115 & 10 & 1 & 52 & 7 & 42 & 3 \\
\hline HORTOLÂNDIA & 99510 & 89 & 95 & 9 & 3 & 36 & 1 & 39 & 7 \\
\hline PAULINIA & 40068 & 81 & 87 & 4 & 2 & 46 & 26 & 6 & 3 \\
\hline COSMÓPOLIS & 36606 & 25 & 28 & 7 & 0 & 3 & 2 & 15 & 1 \\
\hline HOLAMBRA & 5960 & 124 & 125 & 120 & 0 & 0 & 0 & 5 & 0 \\
\hline JAGUARIUNA & 24295 & 83 & 85 & 26 & 7 & 6 & 8 & 35 & 3 \\
\hline TOTAL & 1910782 & 1646 & 2592 & 540 & 45 & 658 & 244 & 891 & 214 \\
\hline
\end{tabular}


O método de estudo basicamente constitui-se de duas formas de abordagens: a primeira envolve estudos hidrogeológicos básicos, visando obter o entendimento das condições naturais de ocorrência da água subterrânea, e as relações entre os demais atributos do meio físico.

A segunda abordagem consiste de estudos da água subterrânea como recurso hídrico e atributo do terreno. Isso implica na avaliação da potencialidade e vulnerabilidade da água subterrânea.

A análise das condições naturais de ocorrência das águas subterrâneas envolve o conhecimento litológico e estrutural (de superfície e subsuperfície) das rochas armazenadoras e condutoras de água subterrânea, a análise do relevo e de seus processos morfodinâmicos, do solo e de suas condições genéticas e das drenagens existentes, como também a caracterização hidroclimática.

Nesta abordagem pretende-se caracterizar a hidrodinâmica da água subterrânea, a determinação de áreas de recarga e descarga e o entendimento do ciclo hidrológico. Os estudos envolvidos são: geometria dos aqüifferos, potenciometria e/ou espacialização dos níveis de água, análise do relevo e processos morfodinâmicos, pedologia e/ou material inconsolidado e balanço hídrico.

A análise integrativa desses estudos resulta na definição das unidades hidrogeológicas, por meio da elaboração de uma carta analítica que sustenta as demais cartografias.

Os resultados da avaliação da água subterrânea como recurso hidrico produzem a carta de produtividade, e como atributo de terreno, a carta de vulnerabilidade natural.

Finalmente, a integração dos diversos temas desenvolvidos neste método resulta em uma carta sintese, voltada ao planejamento territorial e a análise ambiental. Nesta carta, autoexplicativa, estão representados as aptidões, restrições e áreas de conflito da água subterrânea como atributo do terreno e recurso natural. As recomendações e diretrizes serão elaborados e descritos na carta, no sentido de proporcionar subsídios para um desenvolvimento "sustentável" da região.

- Produtividade - a carta de produtividade da área de estudo é elaborada por meio da caracterização hidrodinâmica e da análise da produtividade dos vários sis- 
temas aqüifferos. Com base nos valores de capacidade especifica de cada sistema aqüífero houve uma graduação em alta, média e baixa produtividade. A superposição dos diversos resultados da análise da produtividade de cada sistema analisado produziu a Carta de Produtividade do Recurso Hidrico Subterrâneo. A delimitação de cada graduação obedeceu o zoneamento definido na caracterização hidrodinâmica.

- Vulnerabilidade natural dos aqüiferos - a vulnerabilidade natural dos aqüiferos determinada nesse estudo é modificada do método proposto por Foster \& Hirata (1991). O procedimento se baseia inicialmente na determinação do nível de água, seguido da especificação das unidades de terreno e dos tipos litológicos acima da zona saturada do aqüiffero. O mapa de densidade de drenagem e solo/material inconsolidado auxiliarão na elaboração do mapa de vulnerabilidade e na identificação de zonas de maior permeabilidade.

O resultado da análise desses parâmetros é o índice de vulnerabilidade, expresso em termos relativos, em alto, médio e baixo, trabalhada em escala 1:100.000.

- Carta Orientativa ao Usuário da Água Subterrânea - a carta é o produto resultante da superposição dos mapas de aptidão, onde são destacadas as maiores potencialidade e fragilidade dos aqüiferos, e as áreas de ocorrência de particularidades do comportamento das águas subterrâneas que sejam importantes para o planejamento e a análise ambiental. No caso, as áreas de ocorrência de diabásios em superfície e subsuperficie e o bloco estrutural que comporta as maiores espessuras de sedimentos do Subgrupo Itararé foram destacados na carta. As estimativas de reserva ativa, uso e consumo foram dispostas em legenda, bem como as caracterizações de cada potencial produtivo, vulnerabilidade natural dos aqüiferos e as legislações vigentes. A carta foi trabalhada em 1:100.000, com produto final na escala 1:200.000. 


\section{REGIÃO METROPOLITANA DE CAMPINAS}

\subsection{SITUAÇÃO GEOGRÁFICA}

- "A área de estudo situa-se a cerca de $150 \mathrm{~km}$ da capital do estado, entre os paralelos $22^{\circ} 25^{\prime} \mathrm{S}$ e $23^{\circ} 15^{\prime} \mathrm{S}$ e meridianos $46^{\circ} 30^{\prime} \mathrm{W}$ e $47^{\circ} 35^{\prime} \mathrm{W}$. Os municipios abrangidos pelo estudo compõem a Região Metropolitana de Campinas e é constituída de Americana, Artur Nogueira, Campinas, Cosmópolis, Engenheiro Coelho, Holambra, Horto- lândia, Indaiatuba, Jaguariúna, Monte Mor, Nova Odessa, Paulínia, Pedreira, Santa Bárbara d'Oeste, Santo Antonio da Posse, Sumaré, Valinhos e Vinhedo. Esta região é denominada pela EMPLASA (1993) de Área de Metropolização da Região de Campinas, e ainda envolve municípios em início de processo de ocupação urbana e de características rurais, como Cosmópolis e Holambra.

O projeto de Lei Complementar $n^{0} .70$ de 1995 (D.O.E. de 11/05/95) apresenta uma proposta de criação da Região Metropolitana de Campinas, constituída pelos municípios acima citados com exceção de Cosmópolis e Holambra.

O presente estudo optou pela escolha da área proposta pela EMPLASA (1993) em virtude de englobar municípios de perfil rural e de estágios iniciais do processo de metropolização. Deste modo, obtém-se uma avaliação geral do processo de ocupação a nível territorial do espaço geográfico em foco, e especificamente, uma análise atual e completa da situação dos recursos hídricos subterrâneos, tanto em áreas de conurbação urbana como em áreas com agropecuária.

Em termos de gerenciamento de recursos hídricos, a área localiza-se dentro da Unidade de Gerenciamento (UGRHI) 5 , composta das bacias hidrográficas de Piracicaba, Capivari e Jundiaí (Lei $n^{\circ} 9034$, de 27 de dezembro de 1994).

As principais vias de acesso à região são a Rodovia dos Bandeirantes (SP348), Via Anhanguera (SP-330), Rodovia Dom Pedro I (SP-065) e Via Marechal Rondom (SP-300). O mapa de localização da área e seu sistema rodoviário é ilustrado na Figura 1. 


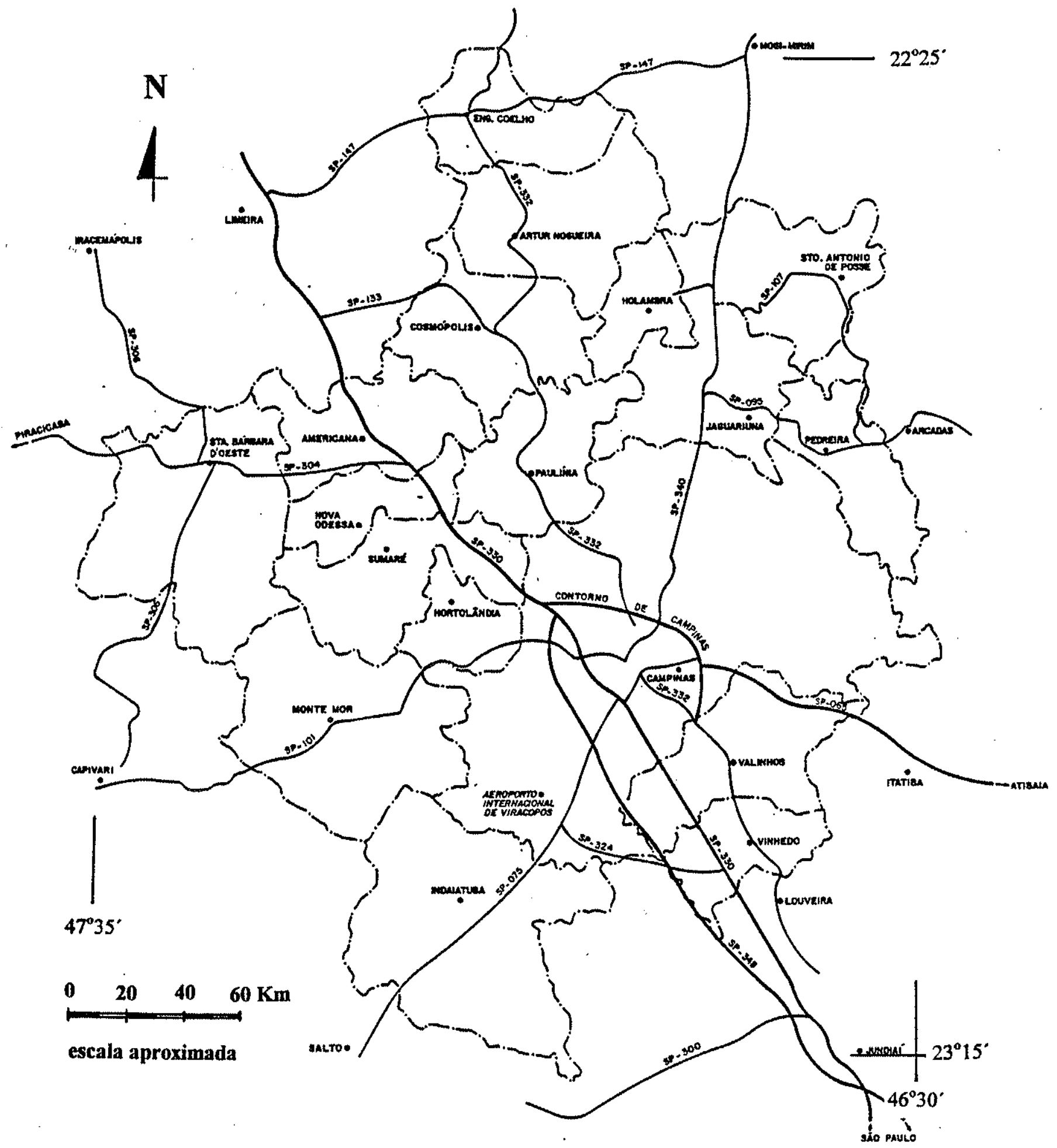

Figura 1 - Mapa de localização e de vias de acesso da Região Metropolitana de Campinas - SP (modificado de EMPLASA 1993) 


\subsection{EVOLUÇÃO SÓCIO-ECONÔMICA}

O surgimento de Campinas remonta ao século XVIII, como pouso de bandeirantes. Em 1774 é elevada a freguesia com a denominação de Nossa Senhora da Conceição de Campinas. Nessa época o cultivo da cana de açúcar em diversos engenhos era a atividade econômica mais importante em detrimento da mineração, já em decadência; em 1797 transforma-se em vila, com a denominação de São Carlos até 1842, quando é elevada a cidade com o nome Campinas. Desse periodo até o final do século XIX, o café foi responsável pela prosperidade, sendo Campinas o centro dos negócios cafeeiros e o principal entroncamento ferroviário do estado, com o cruzamento das Estradas de ferro Paulista, Mogiana e Sorocabana, que visava o transporte da produção cafeeira para o Porto de Santos. Inicia-se na década de 1850 , o processo de industrialização, com a instalação das primeiras fundições necessárias às máquinas de beneficiamento de café e às peças de manutenção das ferrovias (EMPLASA 1993).

No início do século $X X$, o café ainda se destaca entre as atividades econômicas mais importantes; porém há uma tendência de queda na produção pelo esgotamento dos solos e o destaque ao cultivo do algodão, que acaba por substitui-lo como principal produto agrícola. $O$ processo de industrialização continua devido à posição estratégica de Campinas, facilidade de transporte e sua importância como mercado consumidor. Nas décadas de 30 e 40, as atividades urbanas de comércio, indústrias e serviços são as atividades mais importantes, em detrimento da produção agrícola. Há a expansão de centros urbanos e de bairros operários; de modo a haver uma orientação urbanística, efetivado por Prestes Maia, em 1934, com a implementação de um plano urbanístico.

Segundo a EMPLASA (1993), nas décadas de 50 e 60, houve a implantação de grandes indústrias, como a Singer, General Eletric, Bosch, Clark e Rhodia, dentre outras. O industrialização de Campinas ocorre principalmente ao longo dos eixos rodoviários regionais, como a Rodovia Anhanguera, seguida das vias Santos Dumond, D.Pedro I, Bandeirantes e nas rodovias de ligação entre Campinas - Moji Mirim e Campinas - Paulínia. A consolidação do perfil industrial de Campinas a torna o centro industrial do interior; sua mancha urbana se expande com a ocupação de áreas de 
entorno das indústrias e na década de 60 o município é considerado como uma das melhores em padrão urbanístico do pais.

Na década de 70, Campinas passa a condição de grande cidade, e inicia-se o adensamento populacional que se extende em direção aos municípios vizinhos que se situam ao longo da via Anhanguera: Valinhos, Vinhedo, Sumaré, Nova Odessa, Santa Bárbara d'Oeste e Americana. A implantação da REPLAN - Refinaria do Planalto em Paulinia e investimentos do governo na região, como a $\mathrm{COHAB}$, criação de incentivos e políticas na agricultura e instalações de instituições de pesquisa e universidades (UNICAMP), abertura do aeroporto de Viracopos foram os marcos deste período na região.

A atividade agricola também se faz presente nesta região. Atualmente, as principais culturas temporárias são: cana-de-açúcar, milho, tomate e arroz. As principais cidades produtoras são Santa Bárbara d'Oeste, Cosmópolis, Monte Mor; Campinas, Indaiatuba, Artur Nogueira e Sumaré.

Quanto às culturas permanentes destacam-se: laranja, café, tangerina e figo e uva, e as cidades produtoras são Cosmópolis, Santo Antonio da Posse, Santa Bárbara d'Oeste, Indaiatuba, Campinas, Vinhedo e Valinhos.

Holambra se destaca na região por sua história de ocupação pela colônia holandesa e atividade econômica essencialmente agropecuária, com produção diversificada e significativa de produtos como plantas ornamentais, laranja, suinocultura e avicultura.

O processo de crescimento na região é acompanhado da queda da qualidade de vida, com o aumento de favelas e de periferias pobres em Campinas e municípios de entorno, explicada pela intensa industrialização, que também é responsável pelo alto grau de urbanização. Os municípios de Sumaré, Nova Odessa, Americana e Santa Bárbara d'Oeste, situados no eixo da via Anhanguera foram os responsáveis pela maiores taxas de crescimento populacional registradas, causadas pelo próprio processo de industrialização da região. Este crescimento populacional é causado em grande parte pelo processo migratório, especificamente nos municípios de Sumaré, Santa Bárbara d'Oeste, Nova Odessa, Artur Nogueira, Campinas e Vinhedo, que passa de um valor negativo na década de 60 , para valores de mais de $60 \%$ no seu crescimento total absoluto. 
Na década de 80, a metropolização de Campinas é evidente. A implantação de industrias como informática, microeletrônica, telecomunicações e química fina, bem como a ampliação das indústrias tradicionais (metálica, mecânica, material de transporte, papel e celulose, dentre outras), ocorre tanto em Campinas, como nos municípios de Americana, Indaiatuba, Paulínia, Santa Bárbara d'Oeste, Sumaré, Valinhos e Vinhedo. O processo de conurbação, que se inicia na década de 70 se efetiva no periodo seguinte, com o deslocamento da população de Campinas para as cidades vizinhas.

O crescimento praticamente duplicou no periodo de 70 - 80 (passando de 652.450 habitantes em 1970 a 1.235.124 habitantes em 1980), onde este comportamento é visto em cada município componente.

Este aumento súbito da população é decorrente da intensa migração ocasionada pela alta taxa de oferta de empregos com o aumento e diversificação significativos das atividades industriais na região (Tabela 5). A taxa de migração neste período atinge $69,1 \%$ do total de $89 \%$ de crescimento populacional na região, contra $59,1 \%$ dos $68,5 \%$ de crescimento da década passada (EMPLASA 1993). Os municípios que mais receberam migrantes foram Sumaré, seguidos por Santa Bárbara d'Oeste e Nova Odessa; o crescimento relativo destas cidades foram de $341,3 \%, 147,0 \%$ e $162,6 \%$, respectivamente.

Este processo de industrialização gerou um alto grau de urbanização na região, onde em 1991 a taxa chegou a valores acima de 90\% em algumas cidades componentes, como os municípios de Americana, Campinas, Indaiatuba, Nova Odessa, Pedreira, Santo Antonio da Posse, Sumaré e Vinhedo, e altos valores (acima de 75\% com exceção de Artur Nogueira) nos demais municípios (EMPLASA 1993, SEADE 1993).

A qualidade de vida, portanto se reduz, com o crescimento desordenado, que foi característica da ocupação nestas últimas décadas; a situação de instabilidade econômica nacional é um fator agravante para a esta queda. No período de $80-90$, há uma desaceleração do ritmo de crescimento na região. A taxa de crescimento foi de $3,5 \%$ contra $6,6 \%$ na década passada, reflexo do agravamento da crise econômica brasileira. Esta redução é mais significativa nos grandes centros urbanos (Americana e Campinas); este fenômeno de redistribuição espacial da população é observado em 
todo o estado, onde há a migração dos grandes centros para municípios de porte médio a pequenos (EMPLASA 1993).

A Região Metropolitana aqui considerada possui uma população de 1.802 .022 habtitantes, que corresponde a $5,77 \%$ da população total do Estado de São Paulo (EMPLASA 1993). Segundo o Núcleo de Estudos Populacionais (NEPO-UNICAMP 1992 apud EMPLASA 1993), há um "corredor de circulação da população" que se extende pela via Anhanguera e Bandeirantes, e início de expansão deste corredor na direção de Campinas - Sorocaba. Este comportamento é corroborado pela análise do crescimento populacional no periodo de 60 a 91 nesta região de estudo.

Campinas, o municipio mais antigo, foi o centro irradiador da ocupação humana e de certa forma responsável pela criação de novos municipios da região. As emancipações dos municípios mais antigos datam do século passado. Os restantes são bem jovens, com idades menores de cem anos (Tabela 6). A criação de municipios obedeceram leis, que se modificaram ao longo dos anos; assim, até novembro de 1938, a criação de municípios era baseada em leis isoladas. A partir desta data até fevereiro de 1964, o processo foi sistematizado, por meio de revisão geral do quadro territorial e admnistrativo a cada cinco anos (IGC 1993). De fevereiro de $1964 \mathrm{em}$ diante, algumas alterações pontuais foram feitos na lei anterior. Com a Constituição Federal de 1988, novas alterações foram feitas na lei, como a periodicidade, que passa a ser anual e a competência da criação dos municípios passa a ser dos estado (Constituição Estadual de 1989, Lei Complementar n ${ }^{\circ}$ 651/90 e Leis Orgânicas Municipais) (IGC 1993). As emancipações recentes de municipios podem ter como causa principal o alto crescimento populacional e socioeconômico das regiões circunvizinhas de Campinas.

A Regiäo Metropolitana de Campinas sempre possuiu importância econômica e função social, por se situar em local estratégico de caminho para o interior de São Paulo e Minas Gerais, favorecendo a participação de processos históricos de atividades econômicas predominantes, como a cultura do café e a industrialização, com a conseqüente expansão urbana. 
Tabela 5 - Evolução demográfica dos municípios da Região Metropolitana de Campinas no período de 1960 - 1991 (EMPLASA 1993).

\begin{tabular}{|c|c|c|c|c|}
\hline MUNICIPIOS & $\mathbf{1 9 6 0}$ & $\mathbf{1 9 7 0}$ & $\mathbf{1 9 8 0}$ & $\mathbf{1 9 9 1}$ \\
\hline AMERICANA & 37.496 & 66.316 & 122.004 & 153.779 \\
\hline ARTUR NOGUEIRA & 8.194 & 10.171 & 15.941 & 28.044 \\
\hline CAMPINAS & 211.529 & 375.864 & 664.559 & 846.434 \\
\hline COSMOPPOLIS & 8.774 & 12.110 & 23.232 & 36.666 \\
\hline INDAIATUBA & 19.485 & 30.537 & 56.237 & 100.816 \\
\hline JAGUARIUNA & 8.496 & 10.391 & 15.210 & 25.002 \\
\hline MONTE MOR & 6.271 & 7.960 & 14.020 & 25.516 \\
\hline NOVA ODESSA & 5.684 & 8.336 & 21.893 & 34.097 \\
\hline PAULINIA & 5.690 & 10.708 & 20.755 & 36.603 \\
\hline PEDREIRA & 10.816 & 15.053 & 21.383 & 27.756 \\
\hline SANTO ANTONIO DA POSSE & 5.669 & 7.799 & 10.872 & 14.329 \\
\hline SANTA BARBARA D'OESTE & 22.524 & 31.018 & 76.621 & 145.317 \\
\hline SUMARE & 10.488 & 23.074 & 101.834 & 226.225 \\
\hline VALINHOS & 18.266 & 30.775 & 48.922 & 67.867 \\
\hline VINHEDO & 7.869 & 12.338 & 21.641 & 33.571 \\
\hline R.M. CAMPINAS & 387.251 & 652.450 & 1.235 .124 & 1.802 .022 \\
\hline
\end{tabular}

OBS.: os municipios de Holambra, Engenheiro Coelho e Hortolândia não participaram desta avaliação por não haver informaçőes devido a idade de criação recente.

Tabela 6 - Data de criação e origem dos municípios da Região Metropolitana de Campinas.

\begin{tabular}{|c|c|c|}
\hline MUNICIPIO & $\begin{array}{c}\text { ANO DE } \\
\text { CRIAÇÃO }\end{array}$ & $\begin{array}{c}\text { MUNICIPIO DE } \\
\text { ORIGEM }\end{array}$ \\
\hline AMERICANA & $1924^{*}$ & Campinas* \\
\hline ARTUR NOGUEIRA & 1948 & Moji Mirim* \\
\hline CAMPINAS & $1787^{\star}$ & Jundiai $^{*}$ \\
\hline COSMÓPOLIS & 1944 & Campinas* \\
\hline ENGENHEIRO COELHO & 1980 & Artur Nogueira \\
\hline HOLAMBRA & 1991 & Artur Nogueira \\
\hline HORTOLÂNDIA & 1991 & Sumaré \\
\hline INDAIATUBA & $1859^{*}$ & Itu* \\
\hline JAGUARIUUNA & 1953 & Moji Mirim* \\
\hline MONTE MOR & $1871^{\star}$ & $1 \mathrm{tt} \mathrm{u}^{*}$ \\
\hline NOVA ODESSA & 1959 & Americana* \\
\hline PAULÍNIA & 1964 & Campinas* \\
\hline PEDREIRA & $1896^{*}$ & Amparo* \\
\hline $\begin{array}{l}\text { SANTO ANTONIO DA } \\
\text { POSSE }\end{array}$ & 1953 & Moji Mirim* \\
\hline SANTA BÁRBARA d"OESTE & $1869^{*}$ & Piracicaba $^{*}$ \\
\hline SUMARE & 1953 & Campinas* \\
\hline VALINHOS & 1953 & Campinas* \\
\hline VINHEDO & 1948 & Jundiai ${ }^{*}$ \\
\hline
\end{tabular}

Fonte: EMPLASA (1993); * SEADE (1993) 
Assim, na década de 70 e 80 , período de grande desenvolvimento econômico do país, processa-se uma consolidação de uma estrutura industrial na região, seguida da diversificação e sensivel aumento do setor terciário e agrícola. A população economicamente ativa (PEA) da Região Metropolitana de Campinas se concentra no município de Campinas (56,4\% do total da região), que é pólo disseminador da ocupação do solo, e em menores proporções em Americana (10,7\%), Indaiatuba (5,6\%), Valinhos $(4,71 \%)$ e Santa Bárbara D'Oeste (4,66\%) (EMPLASA 1993).

Este processo de urbanização e industrialização desloca a PEA para o setor secundário e terciário. Nos municípios de perfil industrial como Campinas, Americana, Paulínia, Sumaré e Nova Odessa, é sensivel a redução da PEA no setor primário, que naturalmente já possuia baixa porcentagem no início da década de 70 . 0 deslocamento da PEA do setor primário para o secundário e terciário são bem marcantes nos demais municípios, onde a atividade agrícola era mais característica (Cosmópolis, Indaiatuba, Jaguariúna, Santa Bárbara D'Oeste). Artur Nogueira, Monte Mor e Santo Antonio da Posse, em 1980, ainda tem a PEA predominantemente no setor primário.

A industrialização crescente na região, a consolidação de sua estrutura com a implantação de indústrias de ponta e a ampliação das tradicionais, ocorridos no período de 70 a 90, foram responsáveis pela metropolização de Campinas e a conseqüente conurbação na região, que se extende até Piracicaba. Este processo explica o crescimento e o comportamento da população economicamente ativa (PEA).

Na década de 80 , a Região Metropolitana de Campinas apresentou uma redução na taxa de crescimento, reflexo da crise econômica nacional. No entanto, sua participação em âmbito estadual é ciescente, haja visto que em outras áreas industrializadas, como a Região Metropolitana de São Paulo, tiveram sua participação estadual reduzida. 


\subsection{CARACTERIZAÇÃO DO MEIO FÍ́SICO}

\subsubsection{Geologia}

\section{ROCHAS}

A Região Metropolitana de Campinas situa-se na borda leste da Bacia 'Sedimentar do Paraná: na parte oriental da área é encontrado o embasamento cristalino, constituído por rochas metamórficas pré-cambrianas de alto e médio graus do Complexo Itapira e por intrusões de granitos, de idade neo-proterozóica e cambroordoviciana (Granitóides Jaguariúna, Granitos Morungaba e Itu); à oeste, por sedimentos da Bacia Sedimentar do Paraná, especificamente do Subgrupo Itararé, constituído por rochas de variadas litologias (argilitos, lamitos, arenitos, ritmitos, diamictitos) de idade permocarbonífera, e alto grau de complexidade faciológica, representativo de seu ambiente deposicional.

A presença de diabásios da Formação Serra Geral é observada intrudindo as rochas sedimentares em forma de sills e diques, principalmente na parte central da área de estudo. É também notada a presença de extensos corpos de sedimentos cenozóicos cobrindo, em grande parte, os sedimentos do Subgrupo Itararé, como também a presença dos aluviões quaternários, nas margens de rios.

A análise da geologia da área foi baseada nos trabalhos citados a seguir: IG (1995), IG(1993), Souza Filho (1986), Basei, Campos Neto, Bergmann \& Figueiredo (1986), Vlach (1993); CPRM (1974), DAEE/UNESP (1982) e IPT(1981). Esses trabalhos consistem principalmente de mapeamentos geológicos executados em escalas diversas (compreendendo as escalas 1:50.000, 1:100.000, 1:250.000 e 1:500.000) que abrangem partes da área de estudos, como também sua totalidade.

O COMPLEXO ITAPIRA é representado por rochas predominantemente gnássicas. No extremo nordeste da área, à leste de Santo Antonio da Posse, Pedreira e de Jaguariúna, Basei et al. (1986) distinguem dois grupos de rochas indicativas de posições estratigráficas distintas: o Domínio Itapira, constituído por ortognaisses de idade proterozóico médio ou inferior cinza a cinza azulados, hololeucocráticos a leucocráticos, homogêneos e de granulação fina a média, e composição leucotonalítica com fácies granodioríticas e graníticas; e o Grupo Itapira, composto pelos seguintes grupos: granada-biotita-gnaisses granoblástico cinza que passam localmente a granada-muscovita-biotita xisto feldspático e a sillimanita granada 
biotita-gnaisses; biotita-hornblenda-gnaisses, cinza a cinza escuros, bandados com alternâncias de rochas de composições anfibolíticas, dioríticas, quartzo-dioríticas e tonalíticas,granodioríticas, e por fim granada-biotita plagioclásio gnaisse cinza, granolepidoblástico grosso a granoblástico médio e listrado com intercalações de biotita e/ou hornblenda-biotita gnaisse cinza.

Na região de Campinas, o Complexo Itapira possui três domínios estruturais distintos, O domínio ocidental, caracterizado por uma predominância da foliação gnáissica de orientação NE, passando a WNW na parte norte do município de Campinas; o domínio intermediário, de direções NNE, entre a Zona de Cisalhamento Campinas e a Zona de Cisalhamento Campinas, com a ocorrência de rochas - intensamente deformadas (IG 1993). Por fim, o terceiro domínio é encontrado na parte oriental, entre os granitos Morungaba e é conhecida como a"lente gnáissica de Joaquim Egídio", e os gnaisses estão com foliação blastomilonítica e intensamente deformados.

IG (1993) atribui às essas rochas origem supracrustais, assemelhando-se àquelas descritas como Grupo Itapira. No entanto, optou-se pela denominação de "complexo" pela impossibilidade de estabelecimento da estratigrafia desse tipo de rocha, e que é adotada para toda a área de estudo.

Em Campinas, definiram-se os seguintes grupos litológicos: os gnaisses bandados - (hornblenda)-biotita ou biotita-hornblenda gnaisses; biotita-gnaisse laminado a bandado cinza médio; biotita gnaisse granitóide homogêneo ou granito pouco foliado cinza médio ou claro e anfibólio-biotita gnaisse granitóide, cinza rosado ou levemente esverdeado médio inequigranular. Existem os gnaisses xistosos, ocorrendo entre as zonas de cisalhamento, constituindo-se de gnaisses peraluminosos ou (muscovita)-granada-sillimanita-biotita gnaisses xistosos. No grupo das granadas-biotita-gnaisses há o predomínio da granada-biotita gnaisse cinza médio, com olhos de feldspatos centimétricos, biotita-gnaisse fitado e biotita-gnaisse granitóide, como rochas subordinadas.

Os gnaisses indiferenciados constituem um outro grupo e são constituídos por biotita-gnaisse cinza médio, biotita-gnaisse granítico com granada e homogêneo, biotita gnaisse fino mesocrático, biotitamanfibólio gnaisse fino a médio mesocrático, anfibolitos e rochas cálcio-silicáticas.

Essas rochas encontram-se representadas com a sigla $\mathrm{Cl}$ no mapa geológico (Anexo 2) 
Os granitos gnáissicos equigranulares consistem de biotita-granitos gnáissico com granada e/ou turmalina e/ou muscovita, cinza claro e granulação média ou fina equigranular; o último grupo diferenciado o gnaisse granitóide facoidal, é descrito como hornblenda-biotita granitóide gnáissico facoidal, e presença de megacristais de feldspato. Esses dois últimos grupos litológicos encontram-se na "lente gnáissica de Joaquim Egídio" (no mapa geológico, estão representados com a sigla $\mathrm{C} \gamma \mathrm{l}$ ).

"As rochas do Complexo Itapira nas regiões de Vinhedo e Valinhos, consistem basicamente nas mesmas rochas ocorrentes em Campinas e encontram-se representadas, em geral por biotita gnaisses, biotita-hornblenda gnaisses, granadas biotita gnaisses, gnaisses migmatizados, migmatitos de estruturas diversas (IPT 1981).

$\mathrm{Na}$ parte leste, encontram-se os Granitóides Jaguariúna e o Granito Morungaba, ambos de caráter intrusivo e de idade neoproterozóica.

O Granitóide Jaguariúna $(\gamma \mathrm{J})$ situa-se na parte oeste do embasamento cristalino, limítrofe aos sedimentos do Subgrupo Itararé e diabásios da Formação Serra Geral, abrangendo os municípios de Campinas, Jaguariúna e Santo Antonio da Posse. Na região mais ao norte da área, encontram-se biotitamgranitos equigranulares e anfibólios granitóides, de tonalidade cinzento claro a róseo, foliado à maciço, equigranular fino ou médio. Subordinadamente às essas rochas são encontrados gnaisses xistosos. Nas demais área de afloramento desse granitóide, são encontrados os horblenda-biotita granitos gnáissico porfiriticos ou facoidais, cinza rosados a rosa acinzentados, granulometria fina a média e inequigranular, de composição granítica e os biotita-granito gnáissico inequigranular, rosa acinzentados a cinza rosados, inequigranulares, eventualmente porfiróides a porfiríticos, homogêneos, de granulação média a grossa (IG 1993, 1995).

O Granito Morungaba ( $\gamma \mathrm{M})$, também de idade neoproterozóica, situa-se na parte leste do embasamento, especificamente a leste dos municípios de Campinas, Valinhos e Vinhedo. Os tipos de rocha mais representativos são: os biotita-granitos equigranulares leucocráticos, orientados de cores rósea a rósea acinzentada e cinzenta rosada, granulação de média a grossa, os biotita-granitos equigranulares hololeucocráticos, maciços de cloração rósea e granulação média a fina, biotita granitos equigranulares finos com muscovita e granada, biotita-granitos porfiríticos róseos de granulação grossa a muito grossa, e quartzo feldspato pórfiro ou granitóide 
pórfiro que ocorrem como diques de orientação N-S e NE-SW, associados geralmente às principais zonas de fraturas e/ou falhas.

Nas zonas de cisalhamento Campinas e Valinhos, ocorrentes em faixas que cortam de sudoeste a nordeste, encontram-se rochas com alto grau de deformação e com ausências dse tipos litológicos característicos, como os milonitos quartzofeldspáticos e protomilonitos a blastomilonitos.

O Granito ITU $(\gamma \mid)$, extenso corpo de granito, localiza-se ao sul da área de estudo, abrangendo a parte leste do municipio de Indaiatuba. Consistem de granitos a granodioritos alóctones, isótropos, de granulação fina a grossa, com textura subhipidiomórfica e hipidiomórfica granular, de idade cambro-ordoviciana (CPRM 1974, DAEE/UNESP 1982).

$\mathrm{Na}$ parte centro-oeste da área de estudo, o SUBgRUpo ITARARÉ, unidade aflorante da Bacia Sedimentar do Paraná, é representado recobrindo o embasamento cristalino em contato discordante e erosivo, com mergulhos regionais e suaves para oeste. IG (1995) avalia a grande complexidade de se determinar a estratigrafia do Subgrupo Itararé devido ao seu ambiente e período deposicional, e a controvérsias existentes, onde muitos autores consideram glacial, outros, que parte da sedimentação ocorreu em épocas não glaciais e, outros, pós-glaciais. No entanto, pode-se determinar avanços e recuos das geleiras: na base da maioria das colunas, o ambiente deposicional são leques aluviais ou rios braided contemporâneos ou anteriores à ação das geleiras em continentes, que posteriormente evoluiu para um ambiente marinho, talvez interglacial, de plataforma ou transicional, representados por sedimentos finos. O próximo ambiente é o sistema deltáico progradante representados por arenitos, que segundo alguns autores são representativos do avanço de geleiras (IG 1993, 1995).

As litologias encontradas na Região Metropolitana de Campinas são variadas e constituem-se das seguintes unidades faciológicas: arenitos médio a grossos (lam)bem selecionados, subarcoseanos, com presença de estratificação cruzadas de médio a grande porte plano-paralela; ocorre em pacotes de espessura métrica e estão associados arenitos finos a médios, bem selecionados, maciços com estruturas de fluidização, conglomerados polimíticos, grossos e arenitos conglomeráticos estratificados; arenitos finos ou muito finos (laf) (silto-argilosos), com grande variedade de laminações; ritmitos com alternância de lâminas ou camadas argilosas e arenosas com arenitos muito finos ou laminados, argilitos laminados ou siltosos e 
lamitos maciciços; ritmitos turbidíticos (Ira), constituídos de arenitos finos passando gradativamente a argilitos no topo; e lamitos e arenitos pelíticos (Ils), maciços com grânulos esparsos e ocasionais blocos e raros matacões (Anexo 2).

As associações faciológicas de diamictitos, lamitos e ritmitos encontradas na área seriam depósitos de correntes de turbidez com ocasionais corridas de lama em ambiente plataformal ou de planície deltáica. Os lamitos com seixos e blocos representariam fluxos de detritos provenientes de retrabalhamento de depósitos glaciais. Por fim, as unidades de arenitos representariam sedimentos do ambiente deltáico (IG 1993, 1995).

Os DiAbÁsıos (D), pertencentes à Formação Serra Geral, possuem idade jurocretácica e ocorrem em forma de sills e diques, e constituem de corpos de extensão limitada dispersos predominantemente nos sedimentos do Subgrupo Itararé. Segundo IG (1995) os corpos mais alongados tendem a se orientar nas direções NE, NW e EW, estas preferenciais de fraturamentos anteriores e/ou contemporâneos ao evento magmático. O maior corpo encontra-se na parte central da área de estudo, em Campinas, onde se notam juntas subverticais de direções preferenciais N3OW e N48E. Basicamente são descritos como diabásios de granulação fina a muito fina, de coloração cinza escura a preta e estrutura maciça, constituídos principalmente por plagioclásio ripiforme e clinopiroxênios.

Os Depósitos CEnozóicos apresentam-se em grandes extensões na região, principalmente à leste e norte da região de estudo, e ao sul, em corpos menos extensos. IG (1995) subdivide estes depósitos em duas unidades de mapeamento: os depósitos fluviais do tipo meandrante (onde foram observadas 5 fácies: lamitos, arenitos quartzosos, argilitos siltosos, lamitos argilosos e conglomerados) e depósitos coluvionares (lamitos e arenitos pelíticos). IG (1995) descreve uma unidade denominada de "coberturas arenosas", ocupando pedimentos e terraços antigos do rio Piracicaba.

Os depósitos cenozóicos descritos no mapa geológico (Anexo 2) foram divididas nas seguintes unidades litológicas: coberturas arenosas ( $\mathrm{Cca}$ ), ocorrentes nas margens do rio Piracicaba no extremo oeste do município de Americana, constituídas por arenitos médios a grossos, subordinadamente arenitos finos com estratificação plano paralela e cruzada, e cascalheiras. Os lamitos a arenitos pelíticos (Cla) maciços, com grânulos esparsos e pequenos seixos de quartzo subangulosos, de cor acinzentada clara com manchas avermelhadas. Esse depósitos aparecem 
principalmente nos municípios de Hortolândia, Sumaré e Americana com possibilidade de se extender até Santa Bárbara d'Oeste. Os siltitos/arenitos (Csl) muito finos com laminação plano-paralela horizontal e argilitos siltosos com laminação incipiente; arenitos quartzosos grossos com grânulos e seixos por vezes conglomeráticos, mal selecionados e com estratificação cruzada. Por fim, as areias com matriz argilosa, cascathos de limonita e quartzo na base (C), no restante da , área. Souza Filho (1986) identifica depósitos de cobertura de vertente e espigão com predomínio de areias argilosas maciças (coluvionares) sobre raros arenitos estruturados e argilas de rios esporádicos e lagoas de exudação.

Em geral, estas coberturas cenozóicas recobrem os topos e meia encostas de - relevos suaves de colinas amplas. IG (1995) correlacionam essas formações com a Formação Rio Claro e supõe idade terciária para estes depósitos.

Melo (1995) determina para a área de estudo, cinco unidades: duas de idade neocenozóica, que são aluviões em planícies meandrantes e baixos terraços e depósitos colúvio-eluviais areno argilosos em topos e rampas de colinas amplas. As outras três unidades são correlacionáveis à Formação Rio Claro, de idade terciária, subdivididos em corpos com predominância de lamitos de origem gravitacional, com predominância de cascalhos e areias de depósitos associados a canais e depósitos com predominância de argilas de planície de inundação de sistema fluvial meandrante.

Os Aluviões $(Q)$ de idade quaternária consistem de areias finas até grossas, sedimentos silto-argilosos com lentes de areia micácea fina a muito fina, argilas e siltes. 


\section{ESTRUTURAS}

As rochas do Complexo Itapira apresentam foliação gnáissica com atitudes principais NE a NNE (IG 1993), representativas da ocorrência de fases dúcteis. IG (1993) dividem o complexo em 9 domínios no município de Campinas (Figura 2).

Os domínios e suas atitudes principais encontram representados na tabela 7.

Tabela 7 - Domínios e Atitudes principais da foliação gnáissica do Complexo Itapira no município de Campinas (baseado em IG 1993).

\begin{tabular}{|l|c|}
\hline \multicolumn{1}{|c|}{ DOMíNIOS DA FOLIAÇÃo GNÁlSSICA } & ATITUDES MÉDIAS \\
\hline A - extremo norte de Campinas & N40E/79SE \\
\hline B - centro-oeste de Campinas & $\begin{array}{c}\text { N22E/69NW (leste da área) } \\
\text { ENE A WNW/ varea) }\end{array}$ \\
\hline C - zona de cisalhamento Campinas & N20E/mergulhos elevados NW \\
\hline D - extremo norte de Campinas & N20E/mergulhos elevados NW \\
\hline E - faixa central de Campinas (SW a NE) & \\
\hline F - zona de cisalhamento Valinhos & N40W/50SW \\
\hline G - centro-leste de Campinas & N4OW/50SW \\
\hline H - faixa EW na porção leste de Campinas & \\
\hline
\end{tabular}



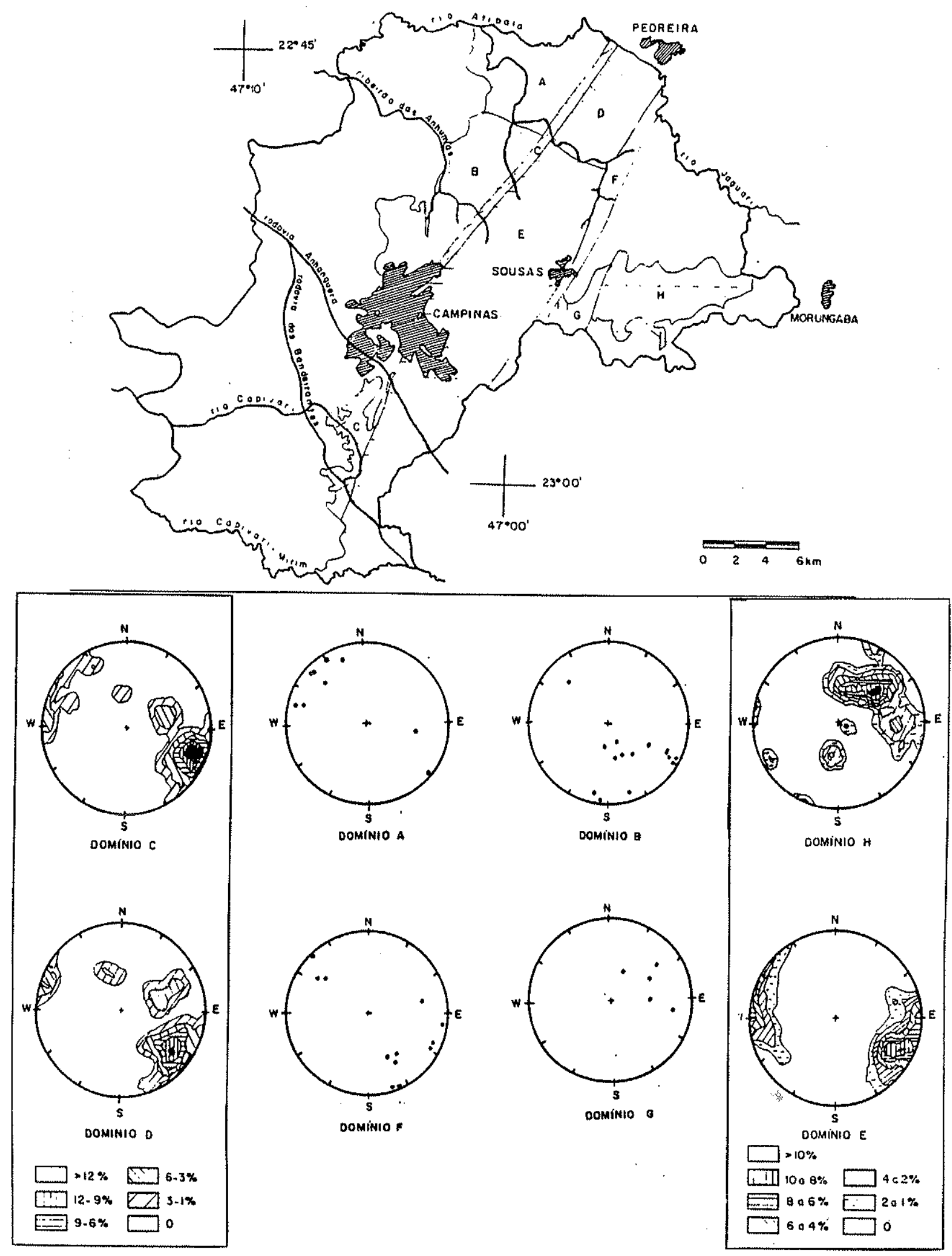

Figura 2 - Mapa de domínios estruturais de foliação acompanhado de estereogramas de projeção polar e de contagem (IG 1993) 
O metamorfismo ocorrido na área é de grau médio a forte, apresentado em alguns pontos migmatização. A idade dessas foliações foi atribuida como sendo do Proterozóico Médio (IG 1993). O Granitóide Jaguariúna apresenta uma foliação de direção NNE a NE; no entanto, não há relação com as rochas do Complexo Itapira, por ser de idade mais recente (Proterozóico Superior) (IG 1993).

As estruturas dúcteis/rúpteis mais destacadas na região são as Zonas de - Cisalhamento Campinas e Valinhos que cortam as rochas de sudoeste a nordeste na área de estudo, e são responsáveis pela presença de rochas miloníticas e blastomiloníticas. Face a isso, as rochas do Complexo Itapira encontram-se afetadas nas proximidades destas estruturas, o mesmo ocorrendo com o Granitóide - Jaguariúna, que apresenta-se foliado, e o Granito Morungaba, que encontra-se brechado. Ao sul de Pedreira e sudeste do Distrito de Souzas ocorrem outras zonas de cisalhamento menos expressivas (IG 1993).

As zonas de cisalhamento de Valinhos e Campinas apresentam direção aproximada N3OE com mergulhos elevados para NW e subordinadamente SE. Na parte norte da área, porção oeste (Santo Antonio da Posse), a zona de cisalhamento Campinas se alarga e inflete para oeste, acompanhando falhamentos de cavalgamento de direção noroeste. Nessa mesma direção falhas transcorrentes são notadas na parte sul do município de Pedreira.

As zonas de cisalhamento Campinas e Valinhos são classificadas como transcorrentes oblíquas.

O Granito Morungaba também demonstra evidências do processos de cisalhamento da região, indicando que a intrusão granítica foi anterior à deformação.

Em termos de tectônica rúptil, na parte oeste da área, a deformação rúptil atingiu rochas miloníticas de zonas de cisalhamento, gerando brechas compostas de fragmentos de milonitos e ultramilonitos (IG 1993). O Granito Morungaba também encontra-se brechado, em uma faixa de direção NE e EW. Falhas rúpteis de direções WNW/ESE a NW/SE provocam deslocamentos pequenos nas rochas graníticas.

Em uma faixa que corta o municipio de Campinas no sentido NE, determinouse que as fraturas de direção NE representam as falhas inversas; as falhas normais, direções ENE a EW, afetando também as coberturas cenozóicas. Na região próxima a Barão Geraldo, norte da área central do município, há falhas normais de direção NE e falhas inversas de direção WNW. Na região campineira próxima à Pedreira e na faixa que corta Campinas no sentido NE, as falhas e fraturas de direção NE a ENE e 
NNE são preferencialmente distensivas. Já na região da "lente gnáissica de Joaquim Egídio", as fraturas e falhas NW, WNW e NNW são distensivas e as de direção NE, ENE e NNE, de caráter compressiva (IG 1993).

IG (1995) determinou para região situada ao norte de Campinas, 8 domínios estruturais (Figura 3). A tabela 8 demonstram os principais dominios e estruturas rúpteis da área (dominios IIA, IB, IIE).

A nivel regional, as estruturas de direção EW aparecem ao longo de rios como - Jaguari e Atibaia. IG (1995) acredita que as estruturas dessa direção seja responsável pela inflexão regional desses rios de NW para EW, nos sedimentos da Bacia Sedimentar do Paraná.

No Subgrupo Itararé em Cosmópolis e Holambra (segundo IG 1995, domínios estruturais IB e IIC) encontraram-se falhas inversas de direção N4OE e merguihos baixos para SE ou NW e fahlhas de direção EW e NW. Em Hortolândia, o Subgrupo Itararé apresenta fraturas conjugadas de direção NNE.

IG (1995) determina três eventos posteriores à idade Juro-Cretácica; em que a mais antiga são representadas pelas falhas destrais de atitude N4OE/84SE; outra de direção WNW, e outras de caráter sinistrais de atitude N56W/82NE. Um outro evento é a que reativou as falhas $\mathrm{N} 4 \mathrm{OE}$, e um outro, o que gerou falhas NW.

Por fim, esse eventos deformacionais rúpteis parecem possuir atividade tectônica Cenozóica, que afetam os depósitos cenozóicos e os diabásios.

A evolução geológica da área é sintetizada na tabela 9.

Pires Neto (1996), dentro de sua análise sobre neotectônica na Bacia do Piracicaba, também concorda com essa hipótese e determina para a região onde se situa a Região Metropolitana de Campinas diversas compartimentações estruturais, cujos limites consistem de grande falhamentos existentes como também de lineamentos em rochas sedimentares da bacia, e que teriam uma atividade atual. Segundo o autor "os blocos estruturais reflete a atividade das estruturas em várias épocas da evolução da região, bem como pulsações com intensidade e sentidos diferentes durante o Cenozóico".

Os blocos estruturais que estão situados dentro da área de estudo, são (Figura 4):

Bloco Lindóia-Valinhos - apresenta um comportamento de soerguimento com relação aos blocos limítrofes, com caimento de norte para sul. 
Bloco-Campinas - assemelha-se a um alto estrutural, evidenciado por sua posição topográfica elevada e divergências de drenagem.

Bloco Jaguariúna - bloco estrutural em elevação com caimento suave para noroeste.

Bloco Jundiai - possui comportamento estável, com adernamento recente para noroeste.

Bloco Itu - soerguimento com adernamento para noroeste.

Bloco Viracopos-Indaiatuba - as feições de relevo existentes sugerem soerguimento lento com caimento para noroeste e outro, do norte para o sul.

Bloco Americana - as evidências de feições geomorfológicas e geológicas sugerem sutil e recente adernamento de bloco para noroeste.

Bloco Capivari - movimentação incipiente.

Bloco Mumbuca - possui soerguimento com adernamento para sul em direção aos rios Capivari e Tietê.

Bloco Pirapintigui - movimentação incipiente com abatimento da parte sul.

O mapa bouguer do estado de São Paulo (IPT 1989) determina na área de estudo três feições crustais principais por meio de modelagem das anomalias gravimétricas mais importantes. Estas feições, que possuem resposta no relevo e dinâmica do terreno, são: o Falhamento Jacutinga, o Lineamento Crustal Tietê, o Falhamento de Socorro. Segundo Pires Neto (1996), estas estruturas de origem crustais são limites dos blocos por ele determinados. Ainda, o Lineamento Porto Feliz-Jacutinga (considerada aqui como as zonas de cisalhamentos Campinas e Valinhos) e o Lineamento Analândia-Jundiaí, obtidos por uma análise local desse mapa bouguer foram considerados (Figura 5). 

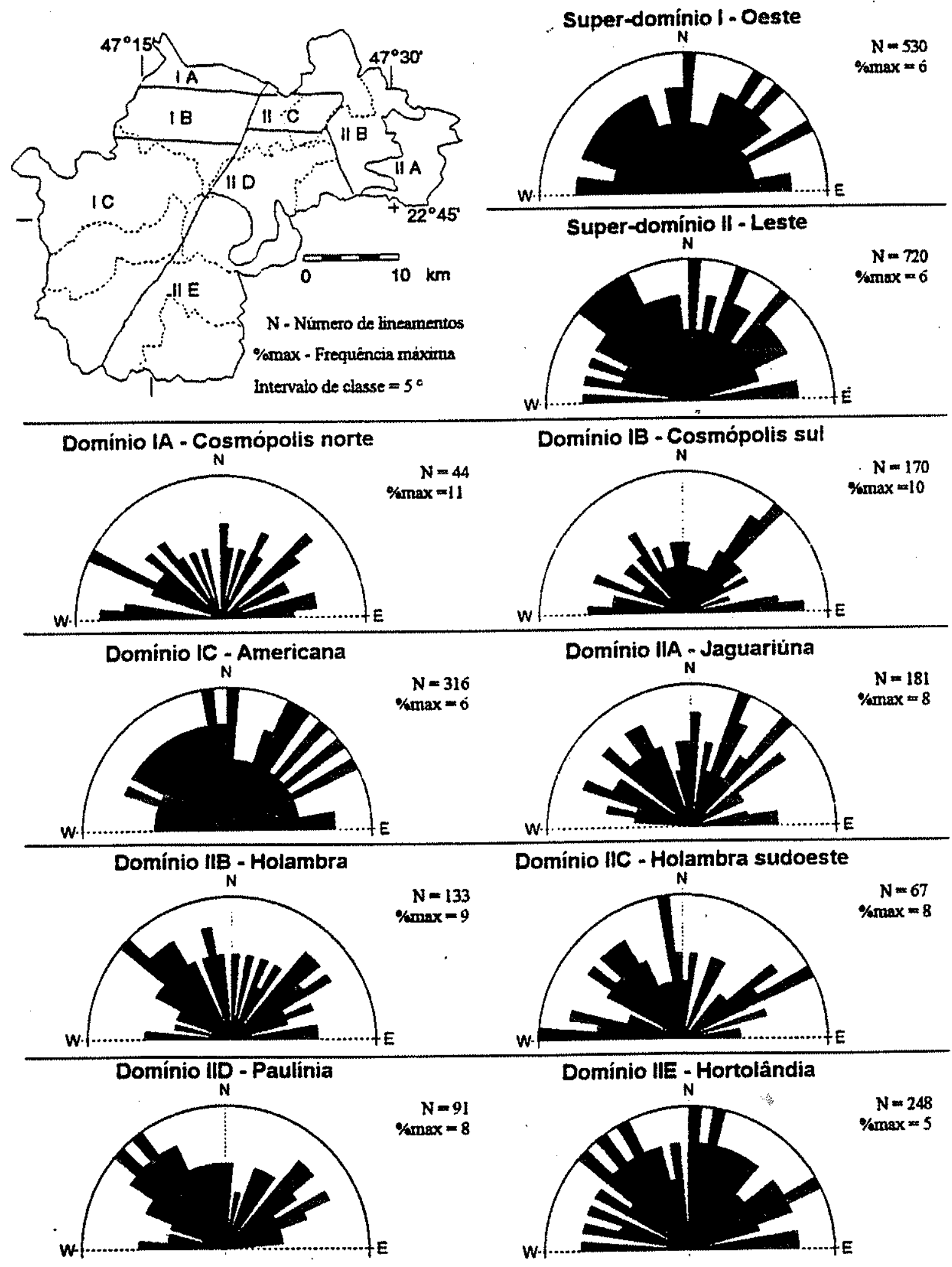

Figura 3 - Orientação dos lineamentos por domínio (IG 1995) 
Tabela 8 - Principais estruturas rúpteis da região norte do município de Campinas (IG 1995)

\begin{tabular}{|c|c|c|c|c|c|}
\hline & ESTRUTURAS & $\begin{array}{l}\text { DIRECCAO/MERGULHO } \\
\text { (MÉDIOS) }\end{array}$ & ESFORÇOS & FEIÇOES ASSOCLADAS & $\begin{array}{l}\text { ROCHAS } \\
\text { AFETADAS } \\
\end{array}$ \\
\hline \multirow{3}{*}{$\begin{array}{l}4 \\
\frac{2}{3} \\
8\end{array}$} & Falhas normais & N38-60W / 55SW & $\begin{array}{l}\sigma 3 \cong \mathrm{N} 20-30 \mathrm{E} / \\
\text { sub-horizontal }\end{array}$ & $\begin{array}{c}\text { - abatimentos topográficos } \\
\text { a SW } \\
\text {-conjugados (N68E/65SE, } \\
\text { N58W/40NE) } \\
\text {-juntas "echelon" (N68W/ } \\
\text { 65NE) }\end{array}$ & $\begin{array}{l}\text { - depósitos } \\
\text { cenozóicos } \\
\text {-grenitóides }\end{array}$ \\
\hline & $\begin{array}{l}\text { Falhas } \\
\text { transcorrentes } \\
\text { destrais }\end{array}$ & $\begin{array}{l}\text { N62E / } 186 \mathrm{NW} \\
\text { EW/72S }\end{array}$ & $\begin{array}{c}\sigma 3 \cong N N E \\
\text { sub-horizontal } \\
\sigma 1 \cong \text { WNW } \\
\text { sub-horizontal }\end{array}$ & $\begin{array}{l}\text {-filhas semelhintes sato } \\
\text { cortadas pelo evento acima }\end{array}$ & -granitöides \\
\hline & Juntas de tracão & $\mathrm{N} 42-60 \mathrm{E} / 58-70 \mathrm{NW}$ & $\sigma 3 \cong N N W$ & $\begin{array}{l}\text { falhas sinistrais N70W } \\
\text { (interpretacio preliminar) }\end{array}$ & $\begin{array}{l}\text { - granitöides/ } \\
\text { gnaisses e } \\
\text { depósitos } \\
\text { cenozóicos }\end{array}$ \\
\hline \multirow{2}{*}{$\frac{\operatorname{m}}{2}$} & $\begin{array}{l}\text { Falhas } \\
\text { transcorrentes } \\
\text { destrais }\end{array}$ & $\begin{array}{l}\text { 86-90E / 85-90N } \\
\text { (comrelacionadas ao } \\
\text { máximo EW) }\end{array}$ & $\begin{array}{l}\text { O3 NE } \\
\text { O1 NW }\end{array}$ & $\begin{array}{l}\text { - máximo de lineamentos } \\
\text { NS devem ser fallhas } \\
\text { antitéticas associadas }\end{array}$ & - diabrásios \\
\hline & Falhas inversas & N40E / 23-40SE ou NW & $\sigma \underset{55 W}{N}$ & $\begin{array}{l}\text { - possiveimente } \\
\text { relacionadias ids } \\
\text { transcomentes }\end{array}$ & -itararé \\
\hline 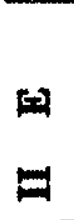 & $\begin{array}{l}\text { Falhas } \\
\text { transcourentes } \\
\text { destrais }\end{array}$ & N40E / 84SE & $\begin{array}{l}\text { o3 NNW } \\
\text { of ENE }\end{array}$ & $\begin{array}{l}\text { såo reativadas por } \\
\text { movimentos inversos } \\
\text { admitindo ol segundo EW }\end{array}$ & - diabásios \\
\hline \multirow{2}{*}{$\frac{2}{8}$} & $\begin{array}{l}\text { Fallhas } \\
\text { trenscorrentes } \\
\text { sinistrais }\end{array}$ & N56W / $82 \mathrm{NE}$ & $\begin{array}{l}\text { o3 NNW } \\
\text { o1 ENE }\end{array}$ & . & - dinbásios \\
\hline & $\begin{array}{l}\text { Fallhas } \\
\text { trenscourentes } \\
\text { destrais }\end{array}$ & NS6W / 82NE & $\begin{array}{l}\text { o3 EW } \\
\text { ol NNW }\end{array}$ & & - diabásios \\
\hline
\end{tabular}


Tabela 9 - Síntese da evolução geológica da Região Metropolitana de Campinas (modificado de IG 1995)

CENOZÓICO- caracterizada pela atividade tectônica rúptil; falhas transcorrentes destrais EW e NE e falhas normais NW. -

-10.000 a. -QUATERNÁRIO - Aluviões e coberturas arenosas

•66 M.a. - TERCIÁRIO - NEÓGENO - depósitos fluviais e coluvionares

\section{PALEÓGENO}

MESOZÓICO

CRETÁCEO

- 208 M.a. JURÁSSICO
Intrusão de diabásios sob a forma de diques e sills segundo as orientações NE, EW e NW.

- 245 M.a. TRIÁSSICO

\section{PALEOZÓICO}

PERMIANO

CARBONÍFERO

- 360 M.a.
Deposição do Subgrupo Itararé, com contribuição de depósitos glaciais ressedimentados, em parte, em canais subaquosos, em ambientes deltáico progradante

DEVONIANO

SILURIANO

ORDOVICIANO

Intrusão do Granito Itu

- 570 M.a. CAMBRIANO

PROTEROZÓICO

•NEO PROTEROZÓICO

•PROTEROZÓICO MÉDIO
Intrusão e deformação dos granitóides Jaguariúna e Granito Morungaba em encaixantes de gnaisses xistosos de idade indefinida

Idade provável da foliação gnássica das rochas do Complexo Itapira 


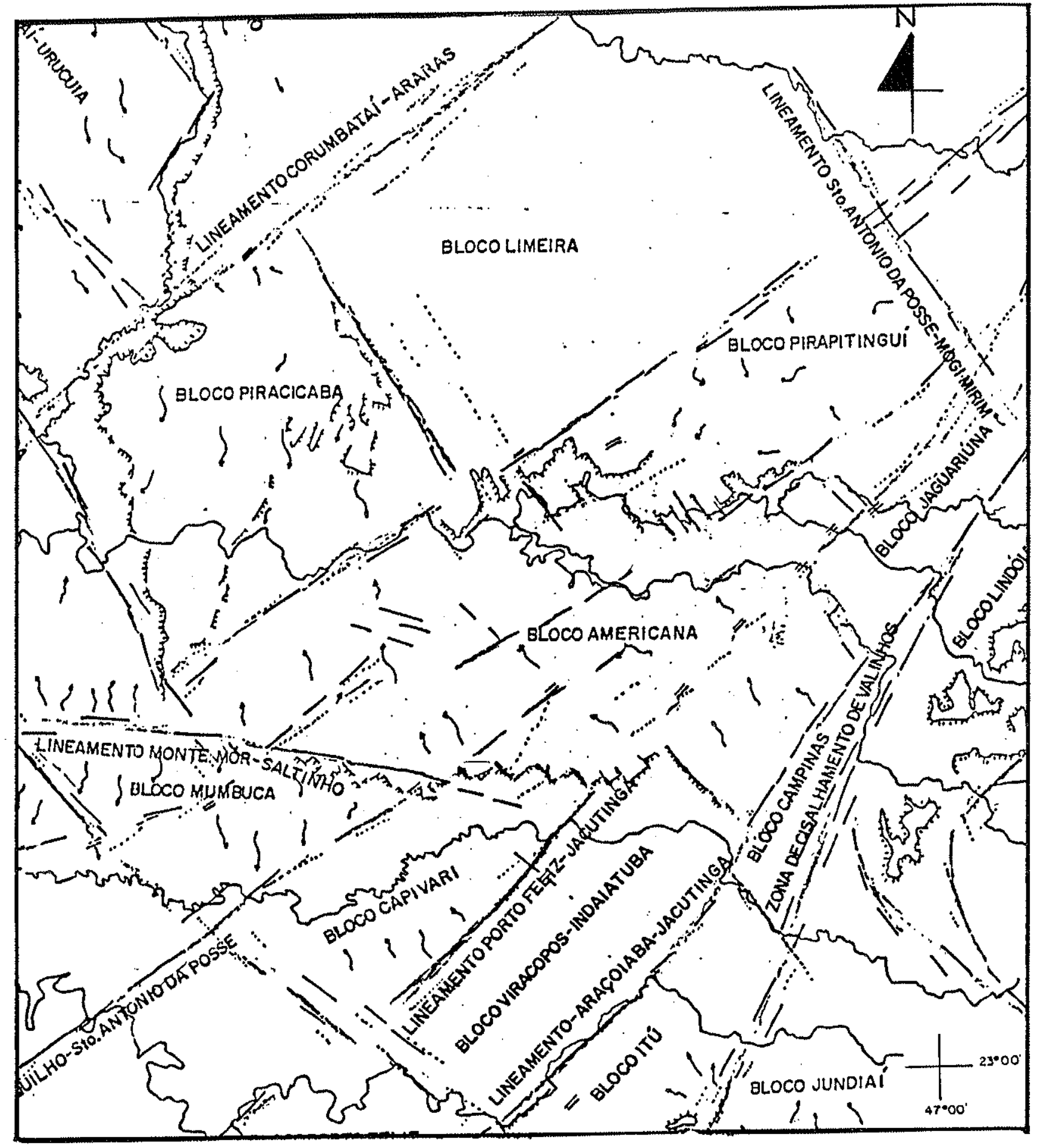

escala $1: 500.000$

Figura 4 - A situação dos blocos estruturais na região (Pires Neto 1996) 


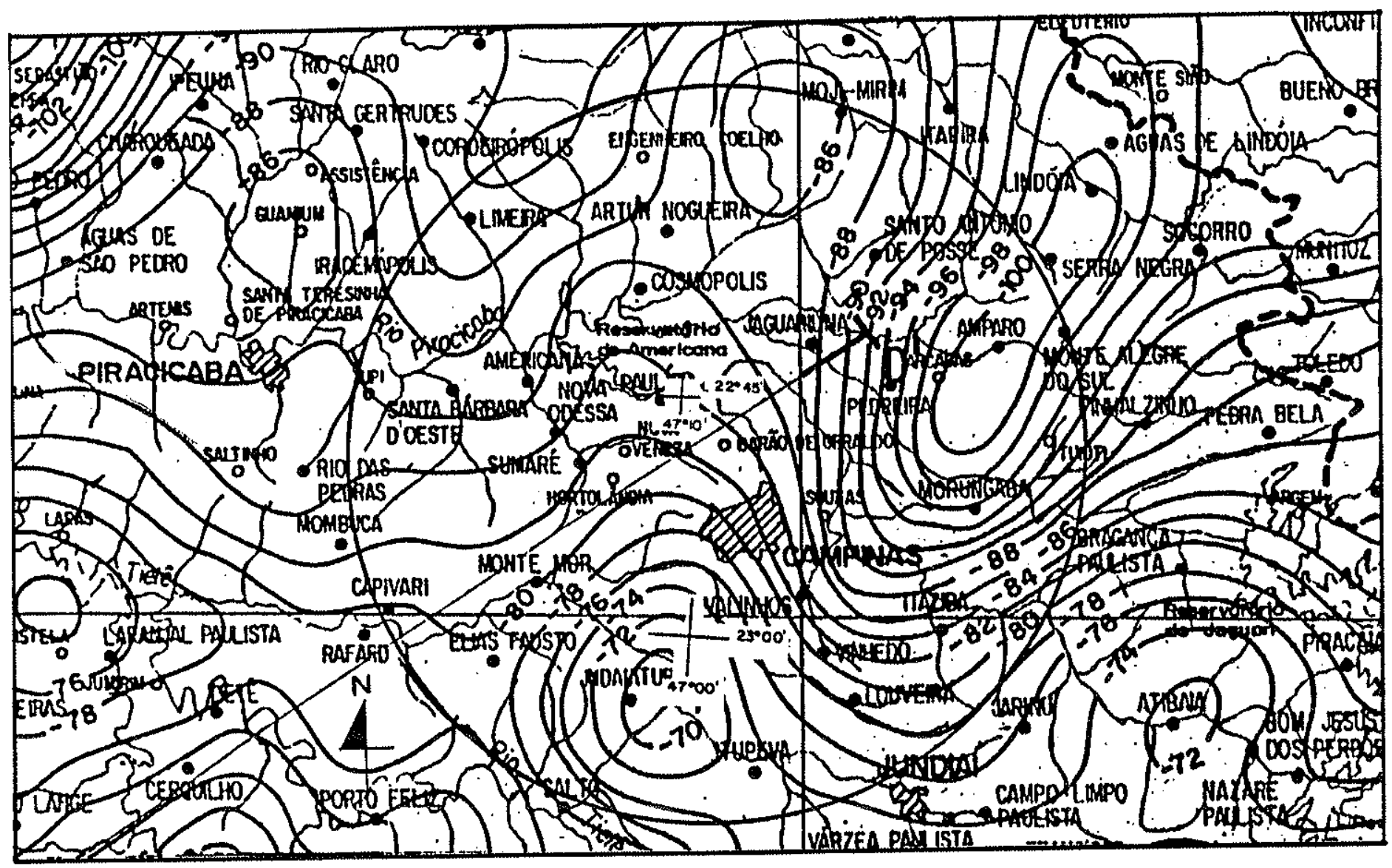

escala 1:1.000.000

Figura 5 - Mapa Bouguer do Estado de São Paulo (IPT 1989) 


\subsubsection{Geomorfologia}

A Região Metropolitana de Campinas situa-se na transição entre duas grandes compartimentações geomorfológicas: o Planalto Atlântico, representado localmente pelo Planalto de Jundiaí, e a Depressão Periférica, pela Zona do Médio Tietê.

Em geral, as formas de relevos possuem uma distribuição relativa às respostas do súsbtrato litológico e estruturas que as suportam; as formas colinosas encontramse na Depressão Periférica, onde se localizam as rochas sedimentares do Subgrupo Itararé e depósitos cenozóicos, e as amorreadas, nas rochas cristalinas do Planalto de Jundiaí. Há ocorrências de formas mistas na zona de transição entre esses dois ' compartimentos geomorfológicos

O Planalto de Jundiai é um planalto rebaixado, subnivelado a 820 a $870 \mathrm{~m}$, e constituído pelos seguintes sistemas de relevo: Mar de Morros, Morros Paralelos, Morros de Topos Achatados, Morros com Serras Restritas, Morros Alongados e Espigöes e Morros Alongados Paralelos (Pires Neto 1996).

$\mathrm{Na}$ área de estudo as formas encontradas são: Morrotes e Colinas de Cimeira (MTCc), Morros e Morrotes (MTM), Morros e Morrotes com matacões (MMT), Morros Paralelos (Mp), Morrotes Dissecados (MTd), Morrotes (MT), Morros Dissecados (Md), Escarpas (E), Escarpas Dissecadas (Ed) e Morro e Montanhas (MMH).

A Depressão Periférica é caracterizadas pelas formas: Colinas amplas de topo horizontais (Cath), Colinas amplas (Ca), Colinas médias e amplas ( $\mathrm{Cma}$ ), Colinas médias $(\mathrm{Cm})$ e Colinas médias e pequenas $(\mathrm{Cpm})$, Colinas pequenas $(\mathrm{Cp})$ e Colinas pequenas dissecadas (Cpd), Terraços Fluviais $(T)$ e Planícies Fluviais $(Q)$.

As formas de transição estão representadas pelas Colinas e Morrotes (CMT) (IG 1993, 1995).

Segundo IG (1995), a regiäo faz parte de um grande pediplano desenvolvido no terciário e que sofre processo de dissecação até os dias atuais, podendo ser correlacionado com a superficie Pd1, de Bigarella (1965 apud IG 1995), ou à Superfície Rio Claro (Penteado 1976 apud 1G1995), onde sempre ocorrem sedimentos cenozóicos.

As Colinas Amplas de Topos Subhorizontais (Cath) e as Colinas Amplas (Ca) são consideradas como remanescentes preservados da superfície erosiva que subnivelou a Zona do Médio Tietê, de idade neogênica. 
A frente de dissecação dessa superfície são representadas pelas formas Colinas Médias e Amplas ( $\mathrm{Cma}$ ), Colinas Médias ( $\mathrm{Cm}$ ) e Colinas Médias e Pequenas (Cmp) (IG 1995). Pires Neto (1996) aventa também a possibilidade destas serem remanescentes do Pd1, hoje isolados e dissecados.

As Colinas Pequenas são os relevos mais recentes resultantes da dissecação e destruição dessa superfície neogênica (Pires Neto 1996).

"No Planalto de Jundiaí, os relevos de Morrotes, Morrotes dissecados, Morrotes paralelos e Morrotes pequenos e as Colinas Pequenas e Morrotes e Colinas e Morrotes, da zona de transição, foram associados a esse evento erosivo. Já os demais relevos do planalto são resultados da profunda dissecação ocorrido em blocos que sofreram uma maior taxa de soerguimento relativo (Pires Neto 1996).

As associações dos tipos de relevo com o substrato rochoso, solo e drenagens estão caracterizados na Tabela 10 e Figura 6. 

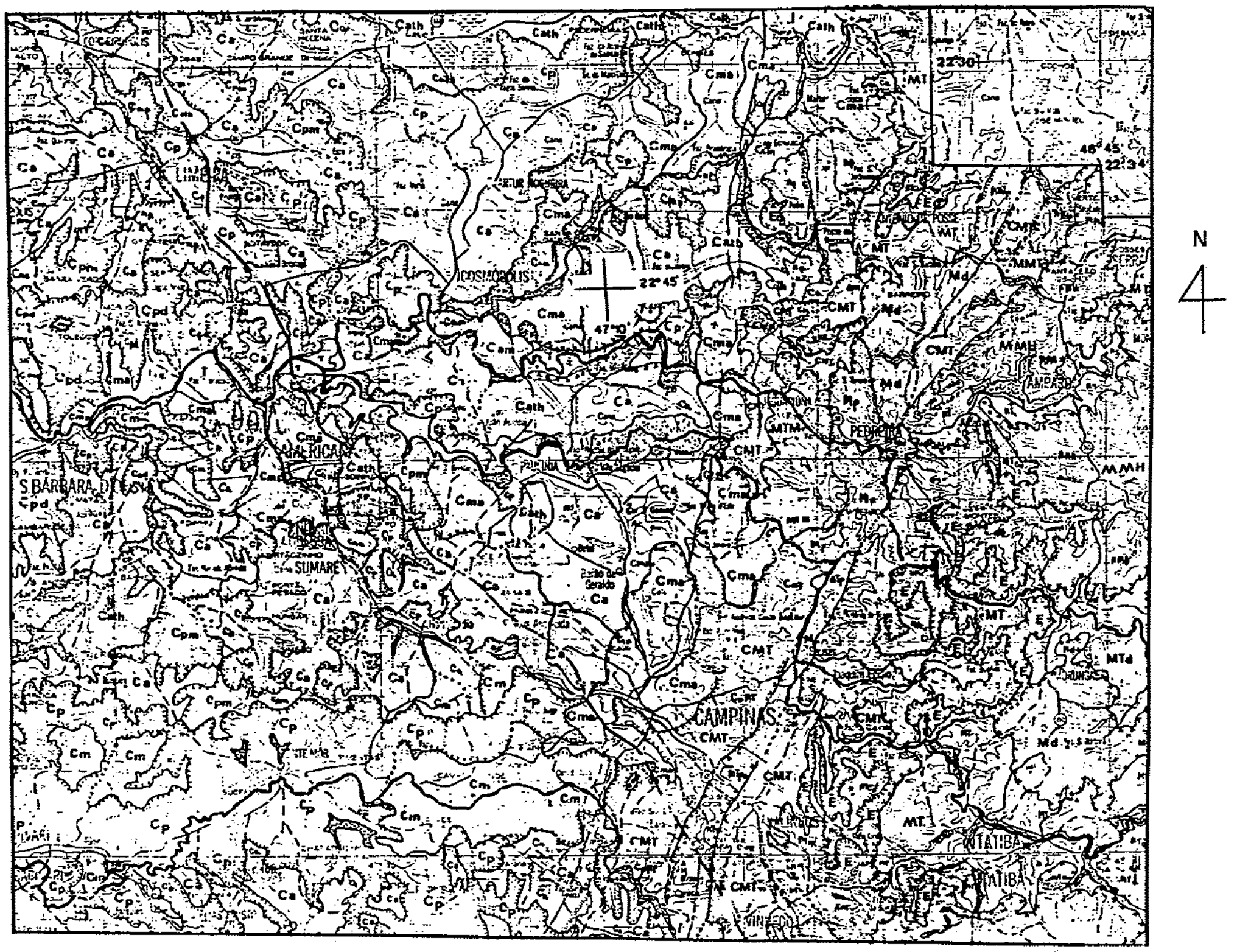

LEGENDA

\section{E - Escarpas}

Ed - Escarpas Dissecadas MMH - Morros e Montanhas

MTM - Morros e Morrotes

Mp - Morros Paralelos

Md - Morros Dissecados

MMT - Morros e Morrotes com matacð̃es

MTCC - Morroles e Colinas de Cimeira

MT - Morrotes

MTd - Morrotes Dissecados

CMT - Colinas e Morrotes

$\mathrm{Cp}$ - Colinas Pequenas

Cpd - Colinas Pequenas Dissecadas

$\mathrm{Cm}$ - Colinas Médias

Cpm - Colinas Pequenas e Médias

Cma - Colinas Médias e Amplas

$\mathrm{Ca}$ - Colinas Amplas

Cath - Colinas Amplas de Topo Horizontais

$T$ - Terraços Fluviais

Q - Planicies Fluviais

Figura 6 - Mapa Geomorfológico da Região Metropolitana de Campinas (Pires Neto 1996) 


\subsubsection{Unidades de Terreno}

Na Região Metropolitana de Campinas foram caracterizados nove Tipos de Terreno (Figura 7).

A gradação de terrenos colinosos a amorreados reflete a transição entre dois compartimentos geomorfológicos regionais: o Planalto Atlântico (no caso, o Planalto de Júundiaí) e a Depressão Periférica (Zona do Médio Tietê). Esta passagem gradacional entre uma região mais acidentada a outra de relevo mais suave, é conseqüência da mudança do tipo de rocha. Nesta área há o contato das rochas do embasamento cristalino com as rochas sedimentares, o diabásio da Bacia Sedimentar do Paraná e os depósitos cenozóicos.

Os relevos amorreados do Planalto Atlântico, situado a leste da área de estudo, são sustentados por rochas cristalinas precambrianas, onde predominam gnaisses diversos, granitos e migmatitos, e subordinadamente, rochas milonitizadas, quartzitos, xistos e anfibolitos, correspondentes ao Complexo Itapira, Granito Morungaba e ltu, o Granitóide Jaguariúna e às Zonas de Cisalhamento Valinhos e Campinas. As diversas formas de relevo são decorrentes das diferenças composicionais e das estruturas maiores existentes nas rochas, as quais conferem a essas, resistências distintas frente aos processos de intemperismo e erosão. A predominância dos solos podzólicos vermelho amarelo, pouco desenvolvidos e de baixa profundidade é característica dessas áreas em franco processo de dissecação.

No extremo leste da área, a alta resistência à erosão das rochas graníticas do Granito Morungaba, preservou os remanescentes da paleosuperfície exumada ltaguá, situados nas áreas de maiores altitudes. A isotropia destas rochas condicionou o padrão de drenagem subdendrítico, cuja densidade, de média a alta, principalmente nos canais de primeira e segunda ordem, reflete a impermeabilidade e as estruturas do material rochoso. A disposição espacial destes elementos abordados é responsável pelas formas amorreadas do relevo.

O solo podzólico vermelho amarelo caracteriza-se pela textura, cujas areias grossas e cascalhos que compõem os horizontes superiores, gradam a argila e siltes em níveis inferiores. Estas características do solo confere ao relevo uma resistência natural aos processos morfodinâmicos. Destaca-se a ocorrência de matacões, resultante do processo de erosão de rochas graníticas por esfoliação esferoidal. 
As demais áreas do planalto são caracterizadas por um relevo fortemente condicionado às estruturas das rochas, que controlam o sistema de drenagem e, por conseqüência, a disposição de suas formas. O padrão de drenagem subdendrítico, subparalelo e treliça encontrado em relevo onde ocorrem as rochas do Complexo Itapira possuem forte condicionamento com a foliação de direção NW e os fraturamentos de direção NE. Na parte sul da área, as formas amorreadas possuem , também forte estruturação em direção NW, que condicionam as drenagens.

Na região norte, as drenagens possuem um padrão paralelo a subparalelo nos relevos onde ocorrem gnaisses do Complexo Itapira e Granitóide Jaguariúna, refletindo uma forte estruturação NE e NW, ocasionada pelas zonas de Cisalhamento - Valinhos, Campinas, como também pelas estruturas (falhamentos transcorrentes e normais) e pela foliação principal dessas rochas, de atitudes NE a NNE. A conformação destes sistemas de drenagem fornece ao relevo local as formas de morros paralelos. Os granitos gnáissicos do Granitóide Jaguariúna condicionam um padrão de drenagem subdendrítico a treliça, similar às rochas do Granito Morungaba, no entanto, a influência da foliação NE das rochas e das direções dos fraturamentos a NE são nítidas nos canais de primeira ordem.

As formas alveolares, a leste da área, estão associadas aos rios Atibaia e Jaguari e são resíduos do processo de dissecação dos relevos de morros. Estão condicionados por soleiras decorrentes dos falhamentos de direção NW, onde a queda de energia do fluxo de água do rio favorece a deposição conseqüente dos materiais sedimentáveis e amplia a planície fluvial nestes locais.

Os processos morfodinâmicos ocorrentes no planalto são resultantes da ação climática da regiäo, conjugada com as características morfográficas e morfométricas dos relevos. A atuação antrópica, cuja história se reporta à época do café, promoveu o desmatamento e a remoção da cobertura superficial do solo, favorecendo a aceleração de processos erosivos.

A Depressão Periférica caracteriza-se pelos relevos resultantes dos processos de pediplanação (Pd1- Neogênica) e dos processos de entalhe e dissecação dessa superfície arrasada.

Os terrenos de colinas, de suave ondulação, representam produtos de pediplanação em clima semi-árido; são suportadas pelos depósitos cenozóicos e de sedimentos e diabásios da Bacia Sedimentar do Paraná, possuindo pequenas amplitudes e drenagens de padrão dendrítico de baixa densidade. As planícies 
fluviais, extensiva até as cabeceiras das drenagens, foram criadas pela acumulação de sedimentos provocada pela baixa energia dos cursos de água e pela proximidade do nivel de base local.

Estas caracteristicas são indicativas de um ambiente senil, onde os processos mais intensos de arrasamento da superfície já ocorreram.

O predomínio do solo Latossolo (roxo e vermelho amarelo) é uma evidência de que ó terreno sofreu um longo período de dissecação, dada a maturidade do solo e sua grande espessura. O Latossolo Roxo, ocorrente sobre as rochas de diabásio da Formação Serra Geral, caracteriza-se por uma textura argilosa e alta permeabilidade superficial. O Latossolo Vermelho Amarelo possui uma textura média e alta permeabilidade e ocorre predominantemente nos depósitos cenozóicos e em ritmitos, arenitos finos e lamitos do Subgrupo Itararé.

O padrão dendrítico de drenagem reflete o comportamento de antigos sistemas fluviais, enquanto que sua baixa densidade é conseqüência da alta permeabilidade dos solos.

$\mathrm{Na}$ parte leste da Depressão, são encontrados os gnaisses do Complexo Itapira. A superfície de pediplanação é notada nestas rochas; no entanto, o padrão de drenagem subdendrítico a subparalelo é o reflexo da foliação gnáissica e da estruturação NE, ocasionada pela Zona de Cisalhamento Campinas, produzindo relevos com formas de colinas e morrotes e morrotes paralelos. É notável o percurso dos rios Atibaia e Jaguari, que se encontram encaixados em estruturas de direção NE.

A interferência desta estruturação da rocha diminui à medida em que esta se dsitancia da zona de cisalhamento; o padrão de drenagem torna-se, então, dendrítico com o surgimento de planícies fluviais indicativos da influência dos processos de pediplanação. O solo predominante é o Podzólico Vermelho Amarelo, com textura areno-argilosa a arenosa nas camadas superficiais e argilosa a siltosa no solo residual.

Assim, os relevos que são suportados pelas rochas do Complexo Itapira (Colinas e Morrotes), constituem uma zona de transição entre a Zona do Médio Tietê (Depressão Periférica) e o Planalto de Jundiaí (Planalto Atlântico).

Na parte sudoeste e sul da região, a ocorrência de relevos colinosos de menor porte (médias e pequenas) é resultante dos processos de entalhe e dissecação da superficie neogênica, que iniciou com o advento das fases úmidas quaternárias. A 
ocorrência de processos morfodinâmicos nas áreas limítrofes de tipos de relevo indica a atividade de dissecação destas antigas superfícies. As Colinas Amplas e Amplas de Topos Sub-horizontalizados são as continuidades da superfície Pd1, remanescentes desse processo de entalhamento, onde estão preservados os depósitos cenozóicos.

As drenagens locais possuem um padrão dendrítico com densidade média. As - diferenças litológicas existentes refletem a densidade de drenagem: nos relevos suportados pelo lamito do Subgrupo Itararé e pelos gnaisses do Complexo Itapira, a densidade de drenagem é alta devido a impermeabilidade do material rochoso. $\mathrm{Na}$ área de ocorrência dos gnaisses do Complexo Itapira (Colinas pequenas e Morrotes),

- o condicionante do padrão atual dos cursos de água foi as antigas drenagens da superficie Pd1.

O solo podzólico vermelho amarelo caracteriza-se por sua textura média, arenosa na porção superficial e siltosa em profundidade, e pequena espessura; são encontrados principalmente sobre as associações de ritmitos, arenitos finos, siltitos, diamictitos e lamitos do Subgrupo Itararé e dos gnaisses do Complexo Itapira, juntamente com os solos litólicos.

Nas áreas de ocorrência dos arenitos, o padrão dendrítico possui menor densidade de drenagem em conseqüência da maior permeabilidade dos terrenos, determinando as formas de colinas médias neste tipo de terreno. O solo predominante é o latossolo vermelho amarelo associado às areias quartzosas podzólicas profundas, no sul de Campinas, caracterizados pela textura arenosa, grandes espessuras e alta permeabilidade.

Os processos morfodinâmicos nos relevos da Superficie Pd1 apresentam baixa a média intensidade, devido a baixa energia potencial do relevo e da presença de cobertura detríticas permeáveis que favorecem a infiltração.

Nos relevos, geralmente colinosos de baixas declividades, onde ocorrem o solo Latossolo, a alta permeabilidade e porosidade deste material favorecem a baixa intensidade e a ocorrência de processos erosivos, bem como proporciona o desenvolvimento de processos deposicionais, evidenciados, pela evolução de planícies fluviais.

Nos solos podzólicos vermelho amarelo, encontrados em relevos de maior movimentação, associam-se os processos erosivos de maior intensidade, com 
formação de ravinamentos e voçorocas, causados pela interferência antrópica e/ou pelo próprio processo de dissecação natural do relevo.

Nos relevos formados pela dissecação do pediplano $\mathrm{Pd} 1$, os processos erosivos somam-se a ocupação urbana, que intensificam a dinâmica superficial com a concentração de águas pluviais e desordenação do escoamento superficial. A remoção da camada superficial do solo provocada por essa ocupação expõe o solo residual mais suscptivel à erosão das águas, fornecendo a formação de processos erosivos de alta intensidade.

As planícies fluviais compreendem as planícies de inundação (várzeas) e os baixos terraços. 
Tabela 10 - Caracterização das Unidades de Terreno e suas associações com o relevo, substrato rochoso, soles e drenagens.

\begin{tabular}{|c|c|c|c|c|c|}
\hline y. & 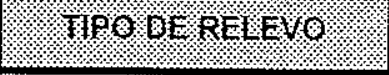 & hesero & SHSSTRHYO & 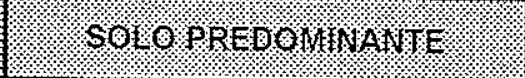 & WhI \\
\hline \multirow[t]{2}{*}{1} & $\begin{array}{l}\text { EscaRPA } \\
\text { Amplitude } 80-300 \mathrm{~m} \\
\text { Compr. Rampa 200- } \\
900 \mathrm{~m} \\
\text { Declividade } 34-42 \%\end{array}$ & \multirow{2}{*}{$\begin{array}{l}\text { Ocorrência de formas } \\
\text { dissecadas e desniveladas, } \\
\text { topos estreitos, convexos e } \\
\text { irregulares com ressaltos } \\
\text { rochosos } \\
\text { Perfil de vertente } \\
\text { descontinuo convexo e } \\
\text { ingreme com matacóes. } \\
\text { Maiores altitudes da área. }\end{array}$} & $\begin{array}{l}\text { gnaisses } \\
\text { homogêneos, } \\
\text { gnaisses bandados, } \\
\text { xistos e anfibolitos }\end{array}$ & \multirow{2}{*}{$\begin{array}{l}\text { Podzólico Vermelho Amarelo, } \\
\text { predomina textura argilosa e Li- } \\
\text { tólicos. Solo superficial areno-ar- } \\
\text { giloso, plástico a muito plástico; } \\
\text { solo residual argiloso, muito } \\
\text { plástico. }\end{array}$} & \multirow{2}{*}{$\begin{array}{l}\text { Vales erosivos, estreitos e encaixados. } \\
\text { Planicies fluviais pouco desenvolvidas. } \\
\text { Densidade de drenagem alta com } \\
\text { padräo subparalelo }\end{array}$} \\
\hline & $\begin{array}{l}\text { ESCARPA DISSECADA } \\
\text { Amplitude } 60-180 \mathrm{~m} \\
\text { Compr. Rampa } 300- \\
1800 \mathrm{~m} \\
\text { Declividade } 10-26 \% \\
\end{array}$ & & $\begin{array}{ll}\text { granitos, } & \text { gnaisses } \\
\text { bandados, } & \text { gnaisses } \\
\text { homogêneos } & \end{array}$ & & \\
\hline \multirow{3}{*}{2} & $\begin{array}{l}\text { MoRROS E MONTANHAS } \\
\text { Amplitude } 130-400 \mathrm{~m} \\
\text { Compr Rampa } 200 \text { a } \\
1400 \mathrm{~m} \\
\text { Declividade } 25-56 \%\end{array}$ & \multirow{3}{*}{$\begin{array}{l}\text { Terrenos com formas } \\
\text { dissecadas e desniveladas; } \\
\text { topos estreitos, convexos e } \\
\text { alongados; alongados com } \\
\text { orientação EW. }\end{array}$} & $\begin{array}{l}\text { gnaisses bandados e } \\
\text { homogêneos, } \\
\text { granitóides }\end{array}$ & $\begin{array}{l}\text { Solos superficiais argilosos com } \\
\text { espessuras em torno de } 1 \mathrm{~m} \text {; } \\
\text { solos de alteração siltosos e de } \\
\text { cor variegada, com espessuras } \\
\text { entre } 5 \text { a } 15 \mathrm{~m} \text {. }\end{array}$ & \multirow{2}{*}{$\begin{array}{l}\text { Vales fortemente encaixados, estreitos } \\
\text { e com pequeno desenvolvimento de } \\
\text { planícies; dinâmica erosiva } \\
\text { predominante. } \\
\text { Densidade de drenagem alta com } \\
\text { padrão subparalelo }\end{array}$} \\
\hline & $\begin{array}{l}\text { MoRRos DisSECADOS } \\
\text { Amplitude } 70-340 \mathrm{~m} \\
\text { Compr. Rampa 200- } \\
1100 \mathrm{~m} \\
\text { Declividade } 16-53 \%\end{array}$ & & $\begin{array}{l}\text { gnaisses homogênos, } \\
\text { gnaisses } \\
\text { diabásios }\end{array}$ & $\begin{array}{l}\text { Solos superficiais argilosos com } \\
\text { espessuras em torno de } 1 \mathrm{~m} \text {; } \\
\text { solos de alteraçäo siltosos e de } \\
\text { cor variegada, com espessuras } \\
\text { entre } 5 \text { a } 15 \mathrm{~m} \text {. Possivel presença } \\
\text { de Terra Roxa Estruturada de } \\
\text { textura argilosa em diabásios }\end{array}$ & \\
\hline & $\begin{array}{l}\text { MoRROS PARALELOS } \\
\text { Amplitude } 70-150 \mathrm{~m} \\
\text { Compr. Rampa 250- } \\
\text { 600m } \\
\text { Declividade } 17-45 \%\end{array}$ & & $\begin{array}{l}\text { gnaisses bandados, } \\
\text { granitos homogêneos, } \\
\text { rochas miloníticas }\end{array}$ & $\begin{array}{l}\text { Podzólico Vermelho Amarelo, } \\
\text { predominando textura argilosa e } \\
\text { litólicos restritos. Solo superficial } \\
\text { areno-argiloso, plástico a muito } \\
\text { plástico e solo residual argiloso. }\end{array}$ & $\begin{array}{l}\text { Vales erosivos, profundos e } \\
\text { encaixados. Planícies fluviais isoladas, } \\
\text { pouco desenvolvidas. } \\
\text { Densidade de drenagem alta com } \\
\text { padräo paralelo a subparalelo }\end{array}$ \\
\hline
\end{tabular}


Tabela 10 (cont.) - Caracterização das Unidades de Terreno e suas associações com o relevo, substrato rochoso, solos e drenagens.

\begin{tabular}{|c|c|c|c|c|c|}
\hline 6 & WO DE REIEVO & 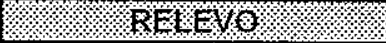 & SUBSTR A O O & 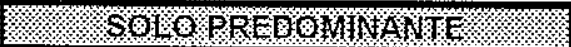 & DRENAGEU \\
\hline \multirow{5}{*}{3} & $\begin{array}{l}\text { MORROTES E MORROS } \\
\text { Amplitude } 60-200 \mathrm{~m} \\
\text { Compr Rampa } 200-900 \mathrm{~m} \\
\text { Declividade } 12 \text { a } 34 \%\end{array}$ & \multirow{5}{*}{$\begin{array}{l}\text { Terrenos de formas } \\
\text { heterogêneas r e } \\
\text { subniveladas, com topos } \\
\text { convexos, estreitos e } \\
\text { forte gradiente de } \\
\text { declividade e amplitudes } \\
\text { variáveis; ropos } \\
\text { alongados com direção } \\
\mathrm{NE}-\mathrm{SW} \text {, vertentes } \\
\text { descontínua, com } \\
\text { presença de blocos e } \\
\text { matacóes de granitos }\end{array}$} & $\begin{array}{l}\text { gnaisses homogêneos, } \\
\text { gnaisses bandados, } \\
\text { granitóides }\end{array}$ & \begin{tabular}{|lr} 
Podzólico Vermelho Amarelo, de \\
textura areno-argilosa, plásticos, com \\
permeabilidade intermediária & e \\
pedregosidade abundante &
\end{tabular} & $\begin{array}{l}\text { Vales fortemente encaixados } \\
\text { estreitos e com pequeno } \\
\text { desenvolvimento de planicies } \\
\text { Densidade de drenagem média a alta } \\
\text { com padröes subdentríticos a treliça. }\end{array}$ \\
\hline & $\begin{array}{l}\text { MORROS E MORROTES COM } \\
\text { MATACōES } \\
\text { Amplitude } 40-90 \mathrm{~m} \\
\text { Compr. Rampa } 250-700 \mathrm{~m} \\
\text { Declividade } 8-25 \%\end{array}$ & & granitóides e granitos & \multirow{2}{*}{$\begin{array}{l}\text { Podzólico Vermelho Amarelo., } \\
\text { predominando a textura argilosa e } \\
\text { litólicos restritos, com solo } \\
\text { superficial areno-argiloso, plástico a } \\
\text { muito plástico e solo residual } \\
\text { argiloso, muito plástico, micáceo. }\end{array}$} & $\begin{array}{l}\text { Vales erosivos e erosivos } \\
\text { acumulativos bem, marcados } \\
\text { predominantemente estreitos. } \\
\text { Densidade de drenagem alta com } \\
\text { padrōes subdendríticos } \\
\text { retangulares. }\end{array}$ \\
\hline & \begin{tabular}{|l|} 
MORROTES PARALELOS \\
Amplitude 55 a $117 \mathrm{~m}$ \\
Compr. Rampa $500-1050 \mathrm{~m}$ \\
Declividade $7,5-17,5 \%$
\end{tabular} & & $\begin{array}{l}\text { rochas miloniticas } \\
\text { indiferenciadas, } \\
\text { gnaisses graniticos, } \\
\text { equigranulares, } \\
\text { bandados existosos } \\
\end{array}$ & & $\begin{array}{l}\text { Vales erosivos-acumulativos } \\
\text { acumulativos estreitos e ber } \\
\text { marcados. } \\
\text { Densidade de drenagem média com } \\
\text { padrão subdendritico }\end{array}$ \\
\hline & \begin{tabular}{|l} 
MORROTES DISSECADOS \\
Amplitude $30-140 \mathrm{~m}$ \\
Compr.Rampa $200-800 \mathrm{~m}$ \\
Declividade $8-40 \%$
\end{tabular} & & $\begin{array}{l}\text { gnaisses bandados, } \\
\text { gnaisses homogêneos }\end{array}$ & \multirow{2}{*}{$\begin{array}{l}\text { Solos superficiais argilosos com } \\
\text { espessuras médias em torno de } 1 \mathrm{~m} \text {; } \\
\text { solos de alteração siltosos, eventual - } \\
\text { mente micáceos, com espessuras } \\
\text { médias de dezenas de metros }\end{array}$} & $\begin{array}{l}\text { Vales erosivos e erosivos } \\
\text { acumulativos bem, marcados } \\
\text { predominantemente estreitos. } \\
\text { Densidade de drenagem alta com } \\
\text { padrões subdendríticos } \\
\text { retangulares. }\end{array}$ \\
\hline & \begin{tabular}{|l|} 
MORROTES \\
Amplitude $20-120 \mathrm{~m}$ \\
Compr. Rampa $200-800 \mathrm{~m}$ \\
Declividade $6-40 \%$ \\
\end{tabular} & & $\begin{array}{l}\text { gnaisses homogêneos, } \\
\text { gnaisses bandados }\end{array}$ & & $\begin{array}{l}\text { Vales encaixados, abertos e dinâmica } \\
\text { erosiva. } \\
\text { Densidade de drenagem alta de } \\
\text { padrăo subdendrítico a retangular }\end{array}$ \\
\hline
\end{tabular}


Tabela 10 (cont.) - Caracterização das Unidades de Terreno e suas associações com o relevo, substrato rochoso, solos e drenagens.

\begin{tabular}{|c|c|c|c|c|c|}
\hline 8.1.1. & MPO BE RE & REVEVO & SUBSTRATO & 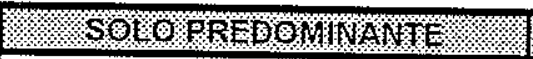 & DENYGENW \\
\hline 4 & $\begin{array}{l}\text { MORROTES E COLINAS DE } \\
\text { CIMEIRA } \\
\text { Amplitude } 30-120 \mathrm{~m} \\
\text { Compr. Rampa } 150-800 \mathrm{~m} \\
\text { Declividade 6-40\% }\end{array}$ & $\begin{array}{l}\text { Formas subniveladas com } \\
\text { topos estreitos, irregulares e } \\
\text { com matacöes. Perfil de } \\
\text { vertente contínuo, convexo a } \\
\text { retilineo com presença de } \\
\text { blocos }\end{array}$ & $\begin{array}{l}\text { granitóides, quartzitos, } \\
\text { gnaisses homogêneos, } \\
\text { gnaisses bandados }\end{array}$ & $\begin{array}{l}\text { Podzólicos Vermelho Amarelo, } \\
\text { predominando a textura argilosa e } \\
\text { litólicos restritos. Solo superficial } \\
\text { areno-argiloso a argiloso e solo } \\
\text { residual argiloso. }\end{array}$ & $\begin{array}{l}\text { Vales erosivos e estreitos nos canais } \\
\text { de primeira ordem. Planicies fluviais } \\
\text { localizadas, isoladas e pouco } \\
\text { desenvolvidas. } \\
\text { Densidade de drenagem média com } \\
\text { padróes subdentritico e retangular }\end{array}$ \\
\hline 5 & $\begin{array}{l}\text { COLINAS E MORROTES } \\
\text { Amplitude } 60-90 \mathrm{~m} \\
\text { Declividade } 14-30 \%\end{array}$ & $\begin{array}{|lr|}\text { Relevo de transição. } & \text { Formas } \\
\text { subniveladas, } & \text { topos } \\
\text { alongados, convexos; } & \text { perfil } \\
\text { de vertente contínua } & a \\
\text { descontinua, convexo } & \text { a } \\
\text { retillineo } & \end{array}$ & $\begin{array}{lr}\text { gnaisses } & \text { bandados, } \\
\text { granitóides } \\
\text { anfibolitos }\end{array}$ & \begin{tabular}{|l|} 
Podzólico Vermelho Amarelo, \\
arenoso a argiloso, permeabilidade \\
intermediária (espessuras entre 0,2 \\
a $4,0 \mathrm{~m}$ )
\end{tabular} & $\begin{array}{l}\text { Vales encaixados, abertos e } \\
\text { dinâmica erosiva. } \\
\text { Densidade de drenagem alta de } \\
\text { padrăo subdendrítico a retangular. }\end{array}$ \\
\hline
\end{tabular}


Tabela 10 (cont.) - Caracterização das Unidades de Terreno e suas associações com o relevo, substrato rochoso, solos e drenagens.

\begin{tabular}{|c|c|c|c|c|c|}
\hline U1. & 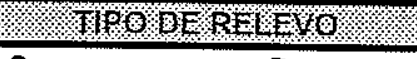 & 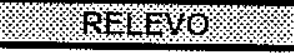 & STBSTRATO & 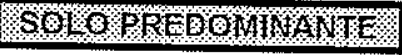 & DREXYKOEMU \\
\hline \multirow{3}{*}{6} & $\begin{array}{l}\text { Colinas } \\
\text { DISSECADAS } \\
\text { Amplitude } 25-100 \mathrm{~m} \\
\text { Compr.Rampa } 250-1200 \mathrm{~m} \\
\text { Declividade } 3-15 \%\end{array}$ & \multirow{3}{*}{ 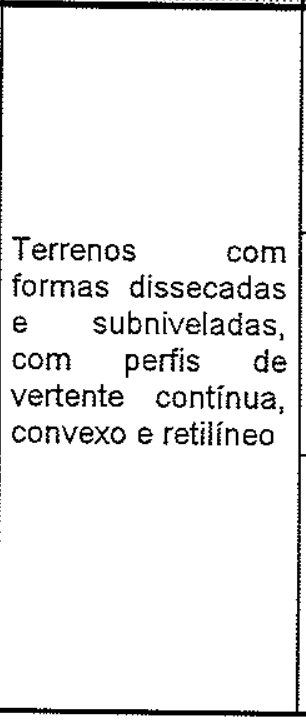 } & $\begin{array}{l}\text { lamitos e depósitos } \\
\text { cenozóicos }\end{array}$ & \multirow{2}{*}{$\begin{array}{l}\text { Podzólico Vermelho } \\
\text { Amarelo, textura arenosa } \\
\text { a média, com solo } \\
\text { superficial arenoso. } \\
\text { de permeabilidade } \\
\text { intermediária e solo } \\
\text { residual argiloso, pouco } \\
\text { permeável }\end{array}$} & $\begin{array}{l}\text { Vales predominantemente } \\
\text { Planícies fluviais estreitas ervos. } \\
\text { desenvolvidas. }\end{array}$ \\
\hline & $\begin{array}{l}\text { Colinas PEQUENAS } \\
\text { Amplitude } 25-100 \mathrm{~m} \\
\text { Compr. Rampa } 150-1100 \mathrm{~m} \\
\text { Declividade } 5-17 \%\end{array}$ & & $\begin{array}{|lr|}\text { lamitos, arenitos } & \text { e } \\
\text { ritmitos do subgrupo } \\
\text { ltararé, } & \text { gnaisses } \\
\text { homogêneos } & \text { e } \\
\text { gnaisses bandados } & \\
\end{array}$ & & $\begin{array}{l}\text { Densidade de drenagem média com padrão } \\
\text { dendritico. }\end{array}$ \\
\hline & $\begin{array}{l}\text { COLINAS MÉDIAS E PEQUENAS } \\
\text { Amplitude } 30-105 \mathrm{~m} \\
\text { Compr. Rampa } 250-1800 \mathrm{~m} \\
\text { Declividade } 4-12 \%\end{array}$ & & 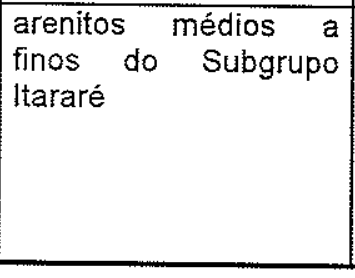 & $\begin{array}{lr}\text { Podzólicos } & \text { Vermelho } \\
\text { Amariolo } & \text { (vertentes), } \\
\text { maciços, sítico-arenosos, } \\
\text { plásticos, boa permeabili- } \\
\text { dade. Secundariamente, } \\
\text { Latossolo Vermelho Ama- } \\
\text { relo (topos), areno-siltoso } \\
\end{array}$ & $\begin{array}{l}\text { Vales predominantemente erosivos e } \\
\text { erosivos acumulativos, estreitos. } \\
\text { Densidade de drenagem média com padrão } \\
\text { dendrítico. }\end{array}$ \\
\hline
\end{tabular}


Tabela 10 (cont.) - Caracterização das Unidades de Terreno e suas associações com o relevo, substrato rochoso, solos e drenagens.

\begin{tabular}{|c|c|c|c|c|c|}
\hline U. & TPOOE REl EVO & REFENO & SUESTRA T. & PREDOUINANUIE & BRENIAGI \\
\hline \multirow[t]{2}{*}{7} & $\begin{array}{l}\text { Colinas MÉDIAS } \\
\text { Amplitude } 20-90 m \\
\text { Compr. Rampa 250- } \\
1700 \mathrm{~m} \\
\text { Declividade } 4-18 \%\end{array}$ & \multirow{2}{*}{$\begin{array}{lr}\text { Terrenos } & \text { com } \\
\text { formas onduladas } \\
\text { e subniveladas, } \\
\text { com r } r \\
\text { convexos ropos } \\
\text { alongados. } \\
\text { Perfil de } \\
\text { continuo, } \\
\text { retilíneo } & \text { convente } \\
\end{array}$} & \begin{tabular}{|lr} 
sedimentos & arenosos $e$ \\
lamíticos, & diabásios \\
(localmente) &
\end{tabular} & 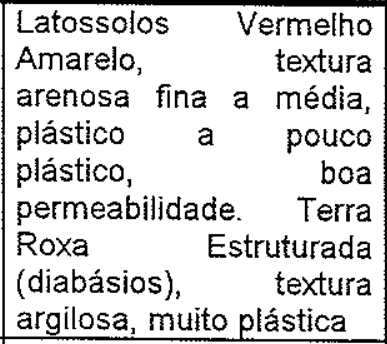 & $\begin{array}{l}\text { Vales abertos, erosivo-acumulativos, sem } \\
\text { desenvolvimento de planícies fluviais } \\
\text { significativas } \\
\text { Densidade de drenagem média com } \\
\text { padrão dendrítico }\end{array}$ \\
\hline & $\begin{array}{l}\text { CoLinAS MÉDIAS EAMPLAS } \\
\text { Amplitude } 20-130 \mathrm{~m} \\
\text { Compr.Rampa } \\
\text { 1950m } \\
\text { Declividade } 3-12 \%\end{array}$ & & $\begin{array}{l}\text { granitos, granitóides, } \\
\text { gnaisses bandados, } \\
\text { arenitos finos e ritmitos; } \\
\text { subordinadamente } \\
\text { diabásios }\end{array}$ & 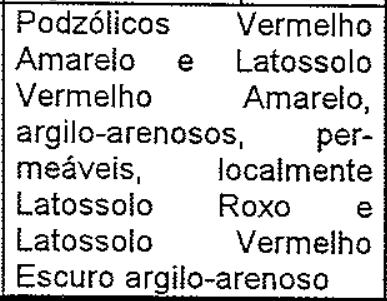 & $\begin{array}{l}\text { Vales acumulativos abertos e bem } \\
\text { marcados, com dinâmica erosiva. Planícies } \\
\text { fluviais estreitas \& desenvolvidas. } \\
\text { Densidade de drenagem média a baixa } \\
\text { com padräo dendrítico. }\end{array}$ \\
\hline
\end{tabular}


Tabela 10 (cont.) - Caracterização das Unidades de Terreno e suas associações com o relevo, substrato rochoso, solos e drenagens.

\begin{tabular}{|c|c|c|c|c|c|}
\hline V.? & WPOER RELEVO & RE Exo. & SEBSTRAK & 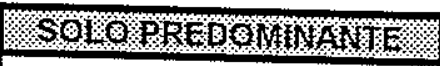 & 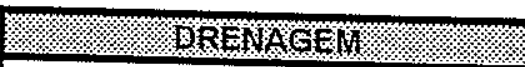 \\
\hline \multirow[t]{2}{*}{8} & $\begin{array}{l}\text { CoLINAS AMPLAS } \\
\text { Amplitude } 20-110 \mathrm{~m} \\
\text { Compr. Rampa } 500-2500 \\
\text { Declividade } 2-9 \%\end{array}$ & \multirow{2}{*}{$\begin{array}{l}\text { Formas amplas, suaves e } \\
\text { subniveladas, com topos amplos } \\
\text { subhorizontalizados com ressaltos } \\
\text { ocasionais; perfil de vertente } \\
\text { conti- } \\
\text { nuo e retilineo, localmente com } \\
\text { segmentos convexos e curtos em } \\
\text { áreas de instrusivas básicas }\end{array}$} & \multirow[t]{2}{*}{$\begin{array}{l}\text { depósitos cenozóicos, } \\
\text { sedimentos variados, e } \\
\text { diabásios }\end{array}$} & $\begin{array}{|lr|}\text { Latossolos } & \text { Vermelho } \\
\text { Amarelo, de textura média a } \\
\text { fina, pouco plásticos, com } \\
\text { permeabilidade relativa } \\
\text { intermediária nos topos e } \\
\text { Podzólicos } & \text { Vermelho } \\
\text { Amarelo } & \end{array}$ & \multirow[t]{2}{*}{$\begin{array}{l}\text { Vales abertos com dinâmica } \\
\text { variável, de erosiva-acumulativa a } \\
\text { francamente acumulativa } \\
\text { Densidade de drenagem baixa com } \\
\text { padrăo dendritico. }\end{array}$} \\
\hline & $\begin{array}{l}\text { ÇOLINAS AMPLAS DE TOPOS } \\
\text { SUBHORIZONTAIS } \\
\text { Amplitude } 20-110 \mathrm{~m} \\
\text { Compr. Rampa } 500-2850 \mathrm{~m} \\
\text { Declividade } 2-9 \%\end{array}$ & & & $\begin{array}{l}\text { Latossolos Roxo e } \\
\text { Vermelho Escuro em topos } \\
\text { e Terra Roxa Estruturada } \\
\text { em vertentes, associadas a } \\
\text { diabásios com solo } \\
\text { superficial argilosa, muito } \\
\text { plástico,alta permeabilidade } \\
\text { e porosidade. }\end{array}$ & \\
\hline
\end{tabular}


Tabela 10 (cont.) - Caracterização das Unidades de Terreno e suas associações com o relevo, substrato rochoso, solos e drenagens.

\begin{tabular}{|c|c|c|c|c|}
\hline 101 & TIPOERERELEVO & REXEX & SUBSTRACOL & 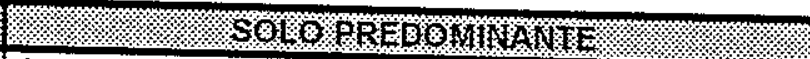 \\
\hline 9 & $\begin{array}{l}\text { TERRAçOS FLUVIAIS } \\
\text { Amplitude } 2-20 \\
\text { Baixa declividade } \\
\end{array}$ & \multirow{2}{*}{$\begin{array}{l}\text { Formas deposicionais } \\
\text { onde associam- } \\
\text { se áreas alagadiças }\end{array}$} & areias e cascalhos & $\begin{array}{l}\text { Solos de espessuras variáveis, de natureza siltico- } \\
\text { argilosa e arenosa }\end{array}$ \\
\hline & $\begin{array}{l}\text { PLANICIES FLUVIAls } \\
\text { Fonte: Pires Neto } 1\end{array}$ & & silte, argilas, areias e cascalhos & Solo Hidromórfico com textura argilosa ou média \\
\hline
\end{tabular}

Fonte: Pires Neto (1996); IG (1995); IG(1993); IPT (1994)

Obs.: U.T. Unidade de Terreno 


\subsection{CLIMA}

\subsubsection{Aspectos Climáticos}

O Estado de São Paulo em virtude de sua posição geográfica (latitude, proximidade do mar, relevo etc. ...) é influenciado pelas principais correntes da circulação atmosférica da América do Sul, a saber, Sistemas Tropicais - Atlântico e Continental -, Sistema Polar Atlântico e finalmente o Sistema Equatorial Continental.

Segundo MONTEIRO (1973) "As facilidades das trocas entre os Sistemas Tropicais e Intertropicais na América Austral, colocam o território Paulista na faixa de conflito entre os dois."

Em relação a participação percentual das principais correntes da circulação Atmosférica Regional no decorrer do ano segundo os anos padrão, (MONTEIRO 1973), a área de estudo encontra-se sob essa faixa de intersecção que flutua de modo geral na direção norte-sul variando a porcentagem de atuação no decorrer do ano, entre correntes tropicais marítimas $(75 \%)$ e correntes polares $(50 \%)$. O período de maior precipitação pluviométrica é a primavera-verão, enquanto que o de menor é o outonoinverno.

É importante salientar que durante os períodos de maior aquecimento da superfície terrestre (à tarde) principalmente na primavera-verão é comum a ocorrência de verdadeiras trombas d'água que são chuvas de convecção (cúmulo-nimbos), intensas e de curta duração (GUTJAHR 1996).

Com relação as temperaturas há um predomínio de temperaturas mais ou menos elevadas, atingindo o máximo em dezembro e janeiro, de maio a agosto as temperaturas são sensivelmente mais baixas, atingindo o mínimo em junho e julho (GUTJAHR 1996). 


\section{a. Análise da cartografia climática}

\section{a.1. Pluviometria Média Anual do período (Figura 8)}

Os valores oscilam entre $1.300 \mathrm{~mm}$. e $1.600 \mathrm{~mm}$, os maiores valores encontramse a leste enquanto que os menores valores estão a sul. É importante salientar que esses valores extremos correspondem a células menores, o que predomina mesmo são os índices entre de 1.400 e $1.500 \mathrm{~mm}$.

\section{a.2. Anos menos chuvosos (Figuras 9 e 10)}

No ano de 1978 (Figura 9), os valores oscilam entre 900 e $1.300 \mathrm{~mm}$, onde é facilmente observável a relativa homogeneidade de distribuição dos valores elevados para um ano pouco chuvoso (1.200 - $1.300 \mathrm{~mm}$.) por toda a área. Isso foge a distribuição considerada normal (relativo a média do período), é o aparecimento de uma célula de valores menores, inferiores a $900 \mathrm{~mm}$. na porção centro-nordeste da área.

No ano de 1985 (Figura 10), a pluviometria oscila entre 900 e $1.300 \mathrm{~mm}$. (como no ano de 1978). Os maiores valores encontram-se a leste da área enquanto que os menores valores estão a oeste e sudeste. Neste ano, a distribuição é semelhante a distribuição normal (relativa à média do periodo Figura 8).

\section{a.3. Ano mais chuvoso 1983 (Figura 11)}

Nesse ano, os valores de precipitação pluviométrica oscilam entre 2.100 e $2.600 \mathrm{~mm}$, com uma amplitude de $500 \mathrm{~mm}$. Os valores mais elevados encontram-se a leste da área de estudo enquanto que os menores valores estão no centro-oeste da área. A região noroeste possui valores próximos a região centro-leste, ou seja aproximadamente $2.200 \mathrm{~mm}$. 


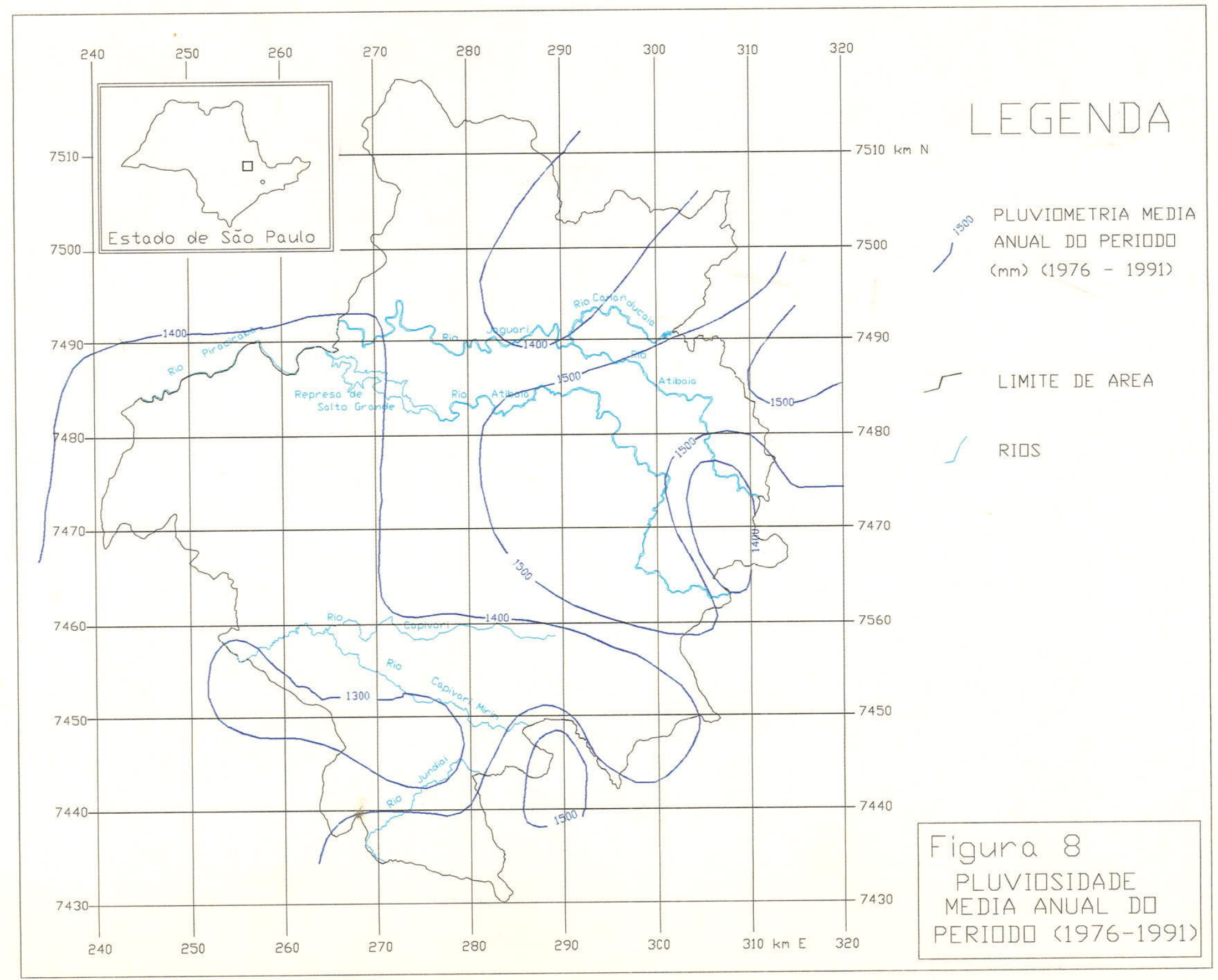




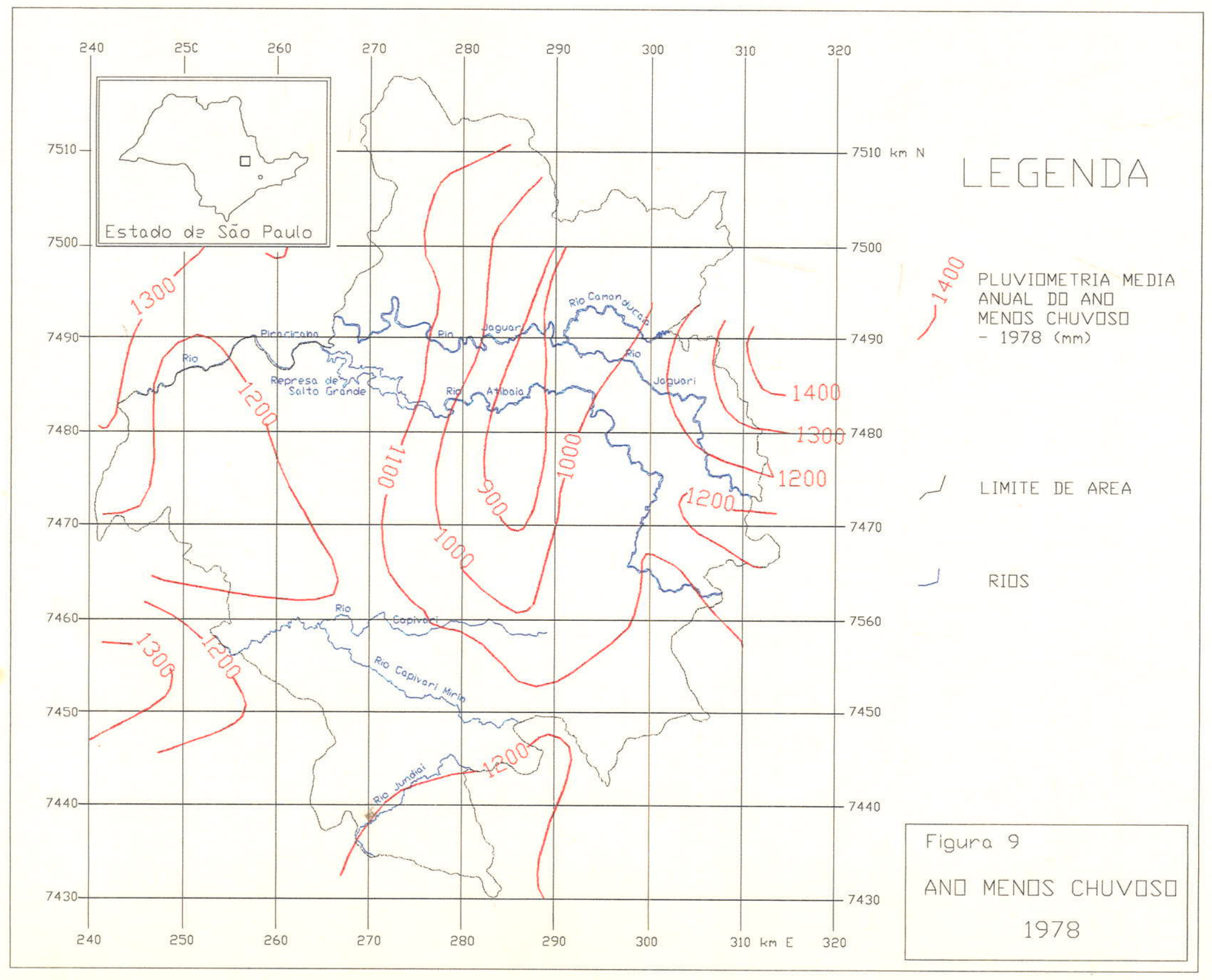




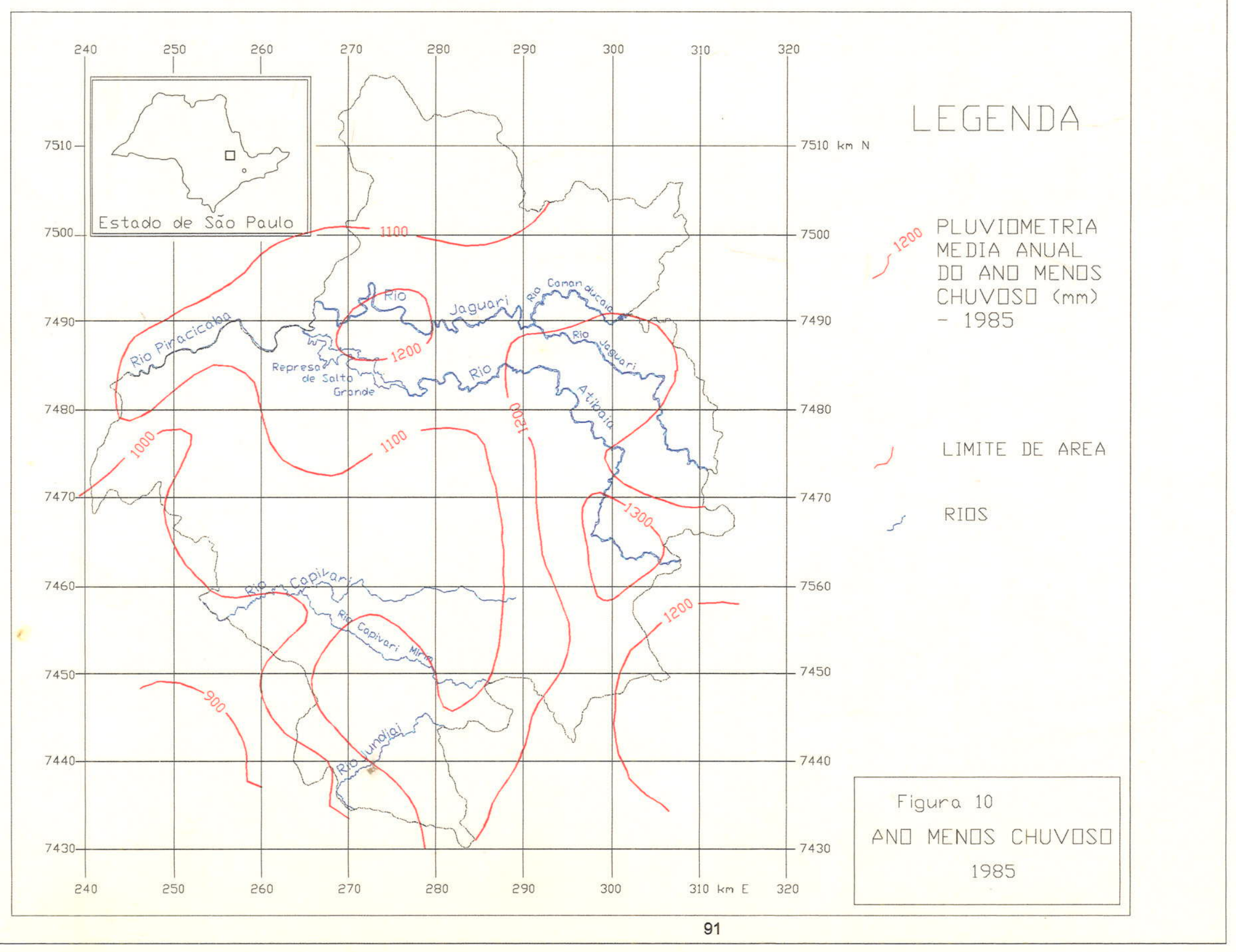




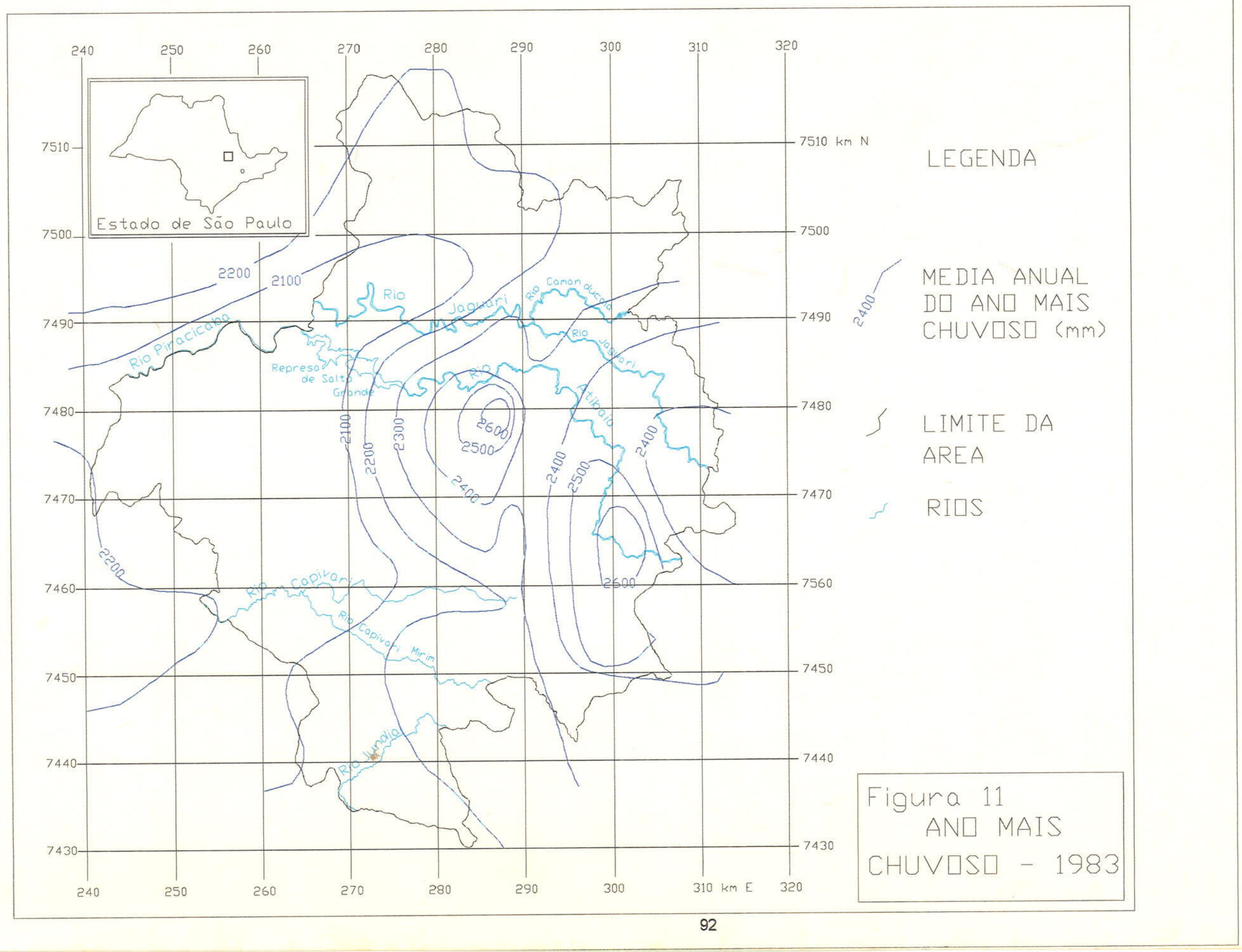


a.4. Trimestre mais chuvoso: Janeiro, Fevereiro e Março (Figura 12)

Os valores oscilam entre 550 e $650 \mathrm{~mm}$., com uma amplitude de $100 \mathrm{~mm}$. A distribuição dos valores mais elevados encontram-se a leste (do centro para o leste), enquanto que os menores valores estão a oeste, sendo que a sudeste aparece a célula com o menor valor, em torno de $550 \mathrm{~mm}$.

a.5. Trimestre menos chuvoso: Junho, Julho e Agosto (Figura 13)

Os valores oscilam entre 120 e $170 \mathrm{~mm}$, com uma amplitude em torno de $50 \mathrm{~mm}$. Nessa análise é facilmente observável a situação dos maiores valores na área do - quadrante sul (principalmente) e leste, enquanto que os menores valores estão a noroeste. Na porção central, os valores oscilam próximos a $140 \mathrm{~mm}$.

b.Análise dos Transectos Temporo - Espaciais relativos a Pluviometria

O objetivo específico da confecção desses transectos foi observar se existe uma diferenciação temporo-espacial entre as áreas que apresentaram as maiores variações nos valores da maioria dos elementos climáticos.

Os maiores valores da variação da precipitação pluviométrica no período (Figura 14) estão restritos ao setor centro-leste, na estação do verão, principalmente no mês de janeiro. A distribuição dos demais valores nos demais meses do ano é praticamente homogênea.

Por sua vez a análise da precipitação pluviométrica nos anos menos chuvosos (1978 e 1985, Figuras 15 e 16 respectivamente) já mostra uma diferenciação bem mais visivel na configuração. Essa configuração é bem mais nítida no ano de 1985. É importante salientar que no decorrer do período nos dois anos (1978 e 1985) existe uma diferenciação bastante nítida na configuração, mas o totais pluviométricos pouco diferenciam-se. 


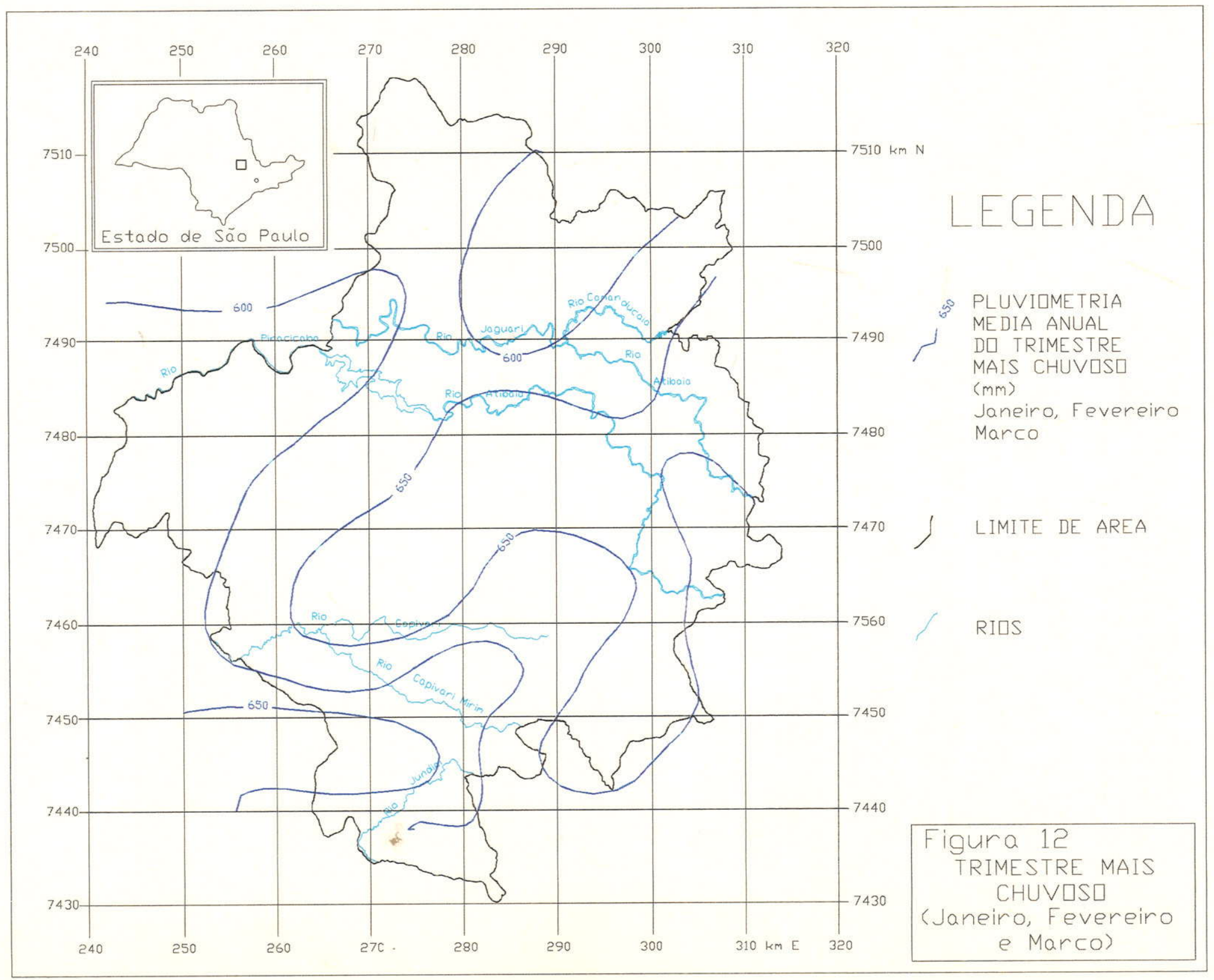

94 


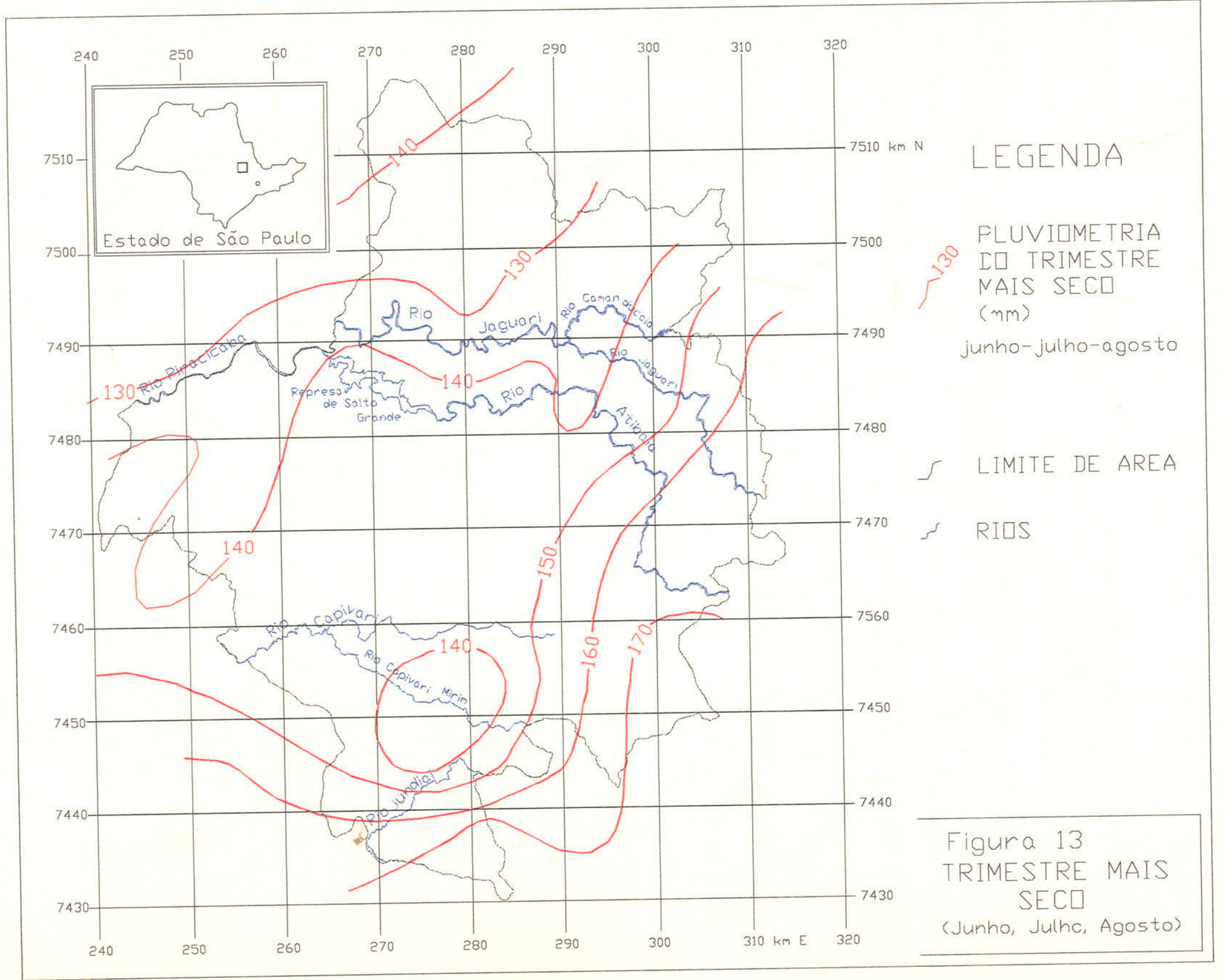


ARCADAS

$760 \mathrm{~m}$

Lat $22^{\circ} 43^{\prime}$

Long $46^{\circ} 50^{\circ}$

PEDREIRA

$590 \mathrm{~m}$

Lat $22^{\circ} 45^{\prime}$

Long $46^{\circ} 56^{\circ}$

FAZ. M. D'ESTE

\section{$600 \mathrm{~m}$}

Lat $22^{\circ} 47^{\prime}$

Long $47^{\circ} 02^{\prime}$

BARÃo GERALDO $630 \mathrm{~m}$

Lat. $22^{\circ} 50^{\prime}$

Long $47^{\circ} 04^{\circ}$
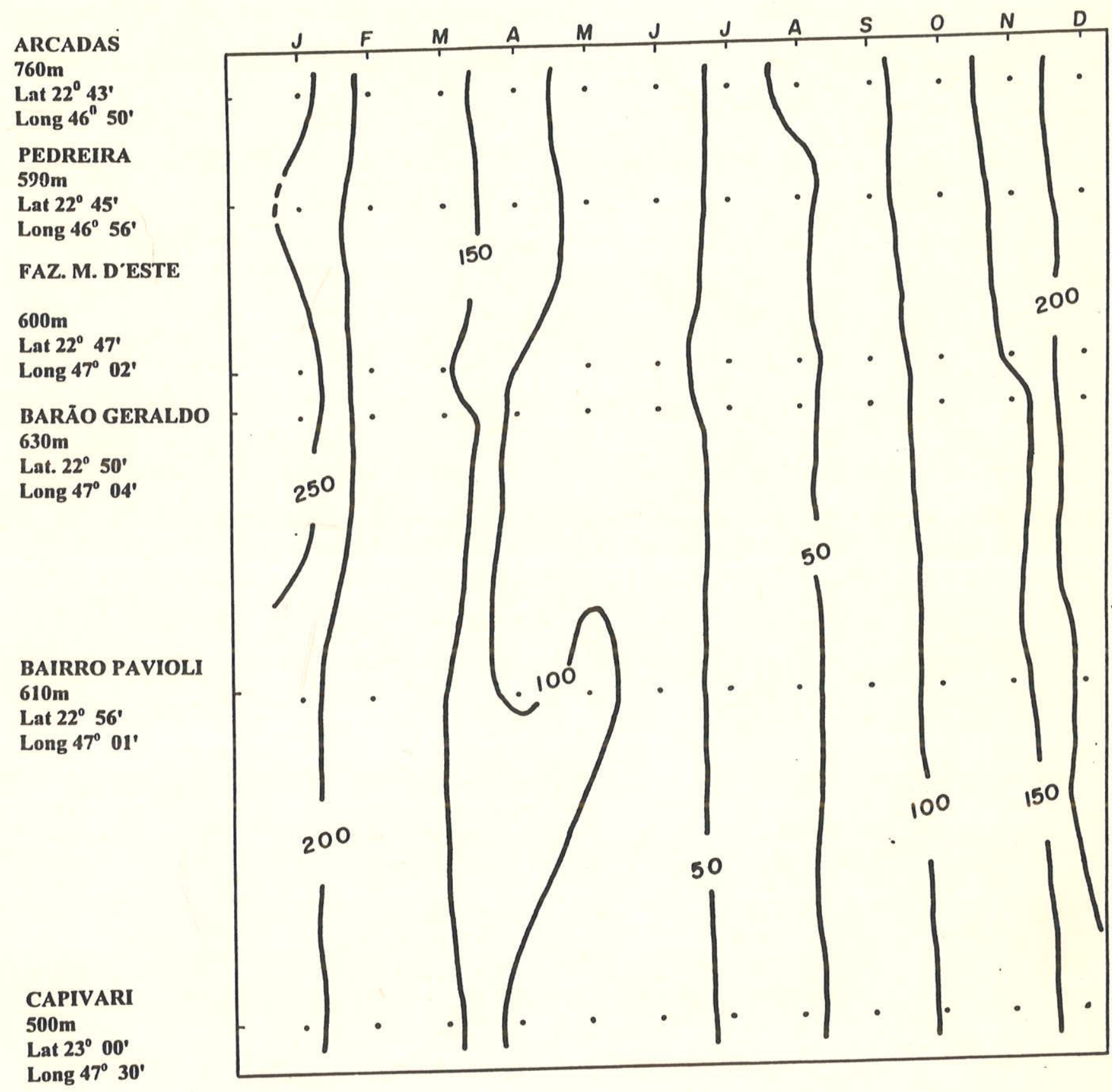

Figura 14 - Variação mensal da precipitação pluviométrica $(\mathrm{mm})$ no transecto Arcadas - Capivari - período 1976 - 1991. 
ARCADAS

$760 \mathrm{~m}$

Lat $22^{\circ} 43^{\circ}$

Long $46^{\circ} 50^{\prime}$

PEDREIRA

$590 \mathrm{~m}$

Lat $22^{\circ} 45^{\circ}$

Long $46^{\circ} 56^{\circ}$

FAZ. M. D'ESTE

\section{$600 \mathrm{~m}$}

Lat $22^{\circ} 47^{\circ}$

Long $47^{\circ} 02^{\circ}$

BARÃO GERALDO $630 \mathrm{~m}$

Lat. $22^{\circ} 50^{\prime}$

Long $47^{\circ} 04^{\circ}$

BAIRRO PAVIOLI

$610 \mathrm{~m}$

Lat $22^{\circ} 56^{\circ}$

Long $47^{\circ} 01^{\circ}$

CAPIVARI

$500 \mathrm{~m}$

Lat $23^{\circ} 00^{\prime}$

Long $47^{\circ} 30^{\circ}$

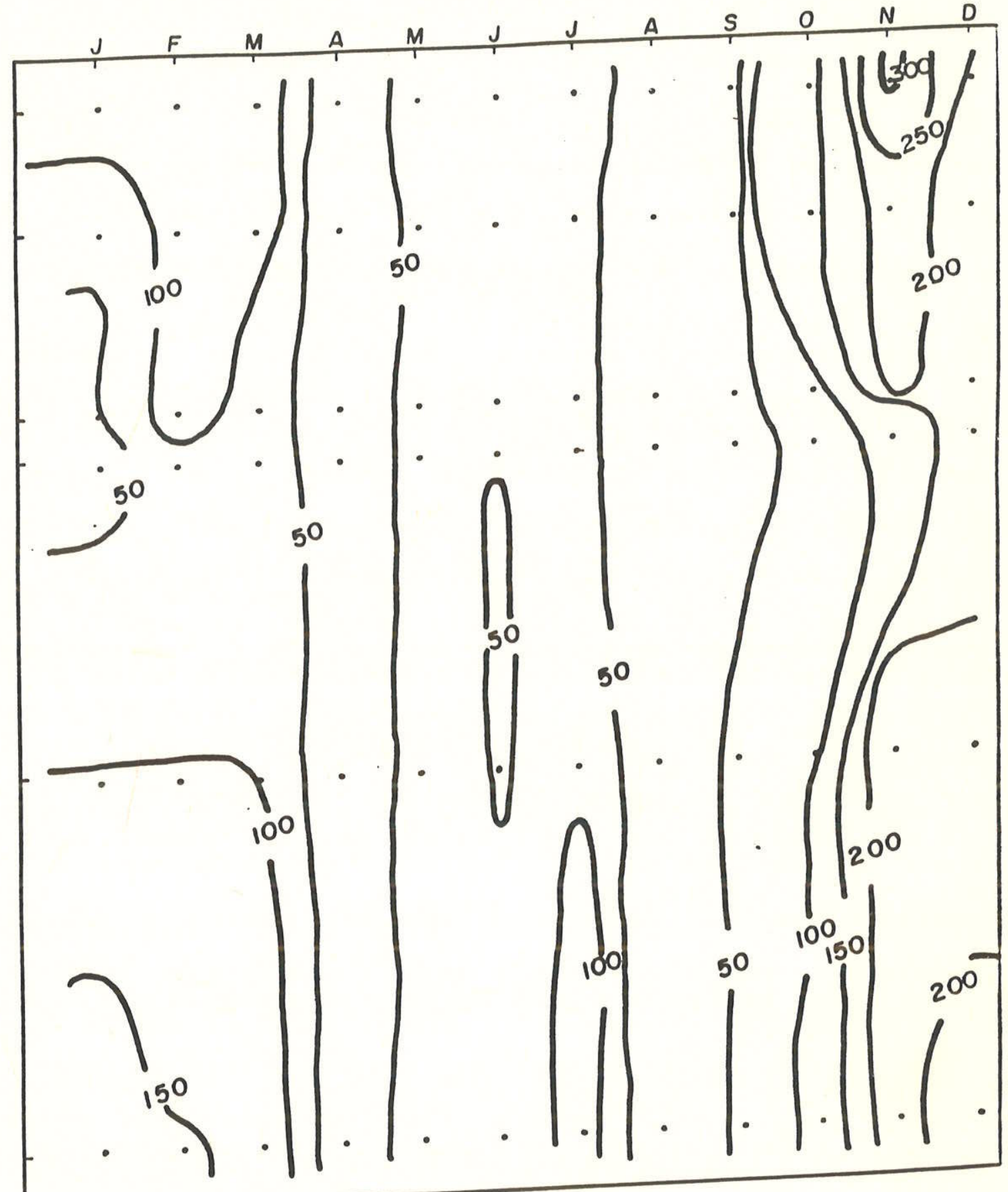

Figura 15 - Variação mensal da precipitação pluviométrica (mm) no transecto Arcadas - Capivari - ano menos chuvoso (1978) 
ARCADAS

$760 \mathrm{~m}$

Lat $22^{\circ} 43^{\circ}$

Long $46^{\circ} 50^{\circ}$

PEDREIRA

$590 \mathrm{~m}$

Lat $22^{\circ} 45^{\prime}$

Long $46^{\circ} 56^{\circ}$

FAZ. M. D'ESTE

$600 \mathrm{~m}$

Lat $22^{\circ} 47^{\circ}$

Long $47^{\circ} 02^{\circ}$

BARÃO GERALDO

$630 \mathrm{~m}$

Lat. $22^{\circ} 50^{\circ}$

Long $47^{\circ} 04^{\circ}$

BAIRRO PAVIOLI

$610 \mathrm{~m}$

Lat $22^{\circ} 56^{\circ}$

Long $47^{\circ} 01^{\circ}$

CAPIVARI

$500 \mathrm{~m}$

Lat $23^{\circ} 00^{\prime}$

Long $47^{\circ} 30^{\prime}$

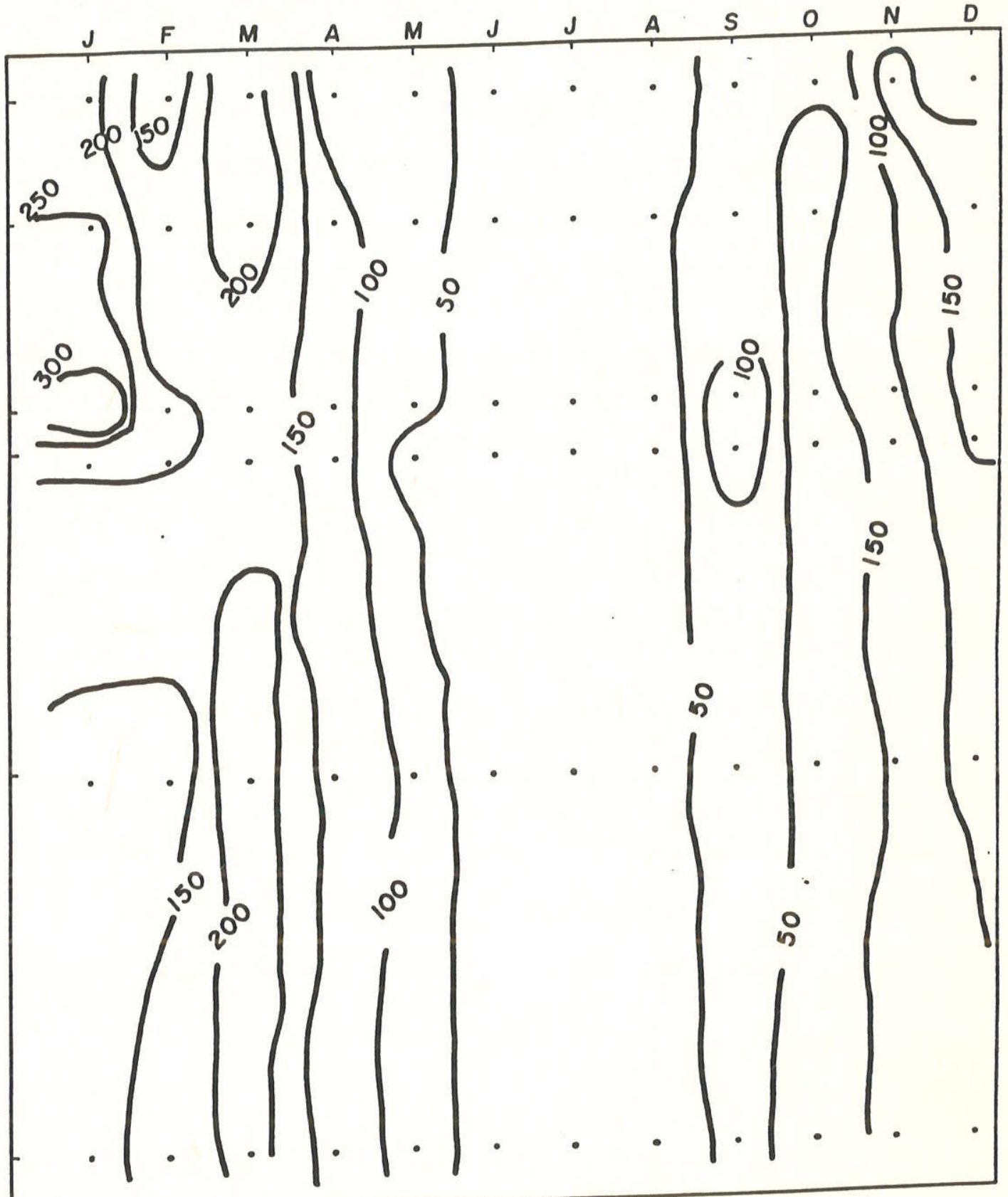

Figura 16 - Variação mensal da precipitação pluviométrica $(\mathrm{mm})$ no transecto Arcadas - Capivari - ano menos chuvoso (1985) 
$\mathrm{Na}$ análise da distribuição da precipitação pluviométrica para o ano mais chuvoso (1983, Figura 17), continua a evidência da diferenciação de duas áreas distintas, em forma da configuração, como também dos montantes, principalmente no final da primavera e nos meses de verão.

Nesses quatro casos fica evidente, na estação de inverno, que as diferenças em termos de configuração são pouco significativos.

\subsubsection{O BALANÇO HÍDRICO}

O conhecimento do montante de precipitação pluviométrica que ocorre em uma determinada área não é suficiente para determinar se esta área é ou não bem servida de umidade, isso nas mais diferentes formas de utilização do recurso água, principalmente quando dispõe-se a executar um planejamento. $O$ fato de uma área estar ou não em regiões que perdem maior ou menor quantidade de umidade por evaporação ou evapotranspiração (ou ambos) é que vai determinar o quanto entrou de umidade, quanto foi perdido e o que sobrou para a utilização. A associação dessas informações aos ambientes bio-geo-físicos, uso do solo e a exploração do recurso água produz o subsídio para o planejamento.

De posse dessas informações, executou-se o Balanço Hídrico Climatológico através do método de THORNTHWAITE e MATHER (1955) pela sua relativa facilidade de obtenção de dados. $O$ que necessita-se em termos de dados são as precipitações pluviométricas em um período homogêneo (1976 a 1991 - 15 anos) e as temperaturas médias (utilizou-se tabelas elaboradas por pesquisadores do Instituto Agrronômico de Campinas -SP, PERDO Jr. et alii 1991 e CAMARGO \& GHIZZI 1991). A capacidade de campo (teor máximo de água que o solo úmido pode reter contra a ação da gravidade) escolhida foi $125 \mathrm{~mm}$.

O Balanço Hídrico foi executado com o intento de proporcionar subsídios para a definição das feições e das células climáticas individualizadas, pois como foi salientado anteriormente, o importante (neste estudo) é o conhecimento das disponibilidades hídricas e sua distribuição no espaço e no tempo. As figuras que representam essa realidade são: Evapotranspiração Potencial (Figura 18) e Excedente Hídrico (Figura 19). 


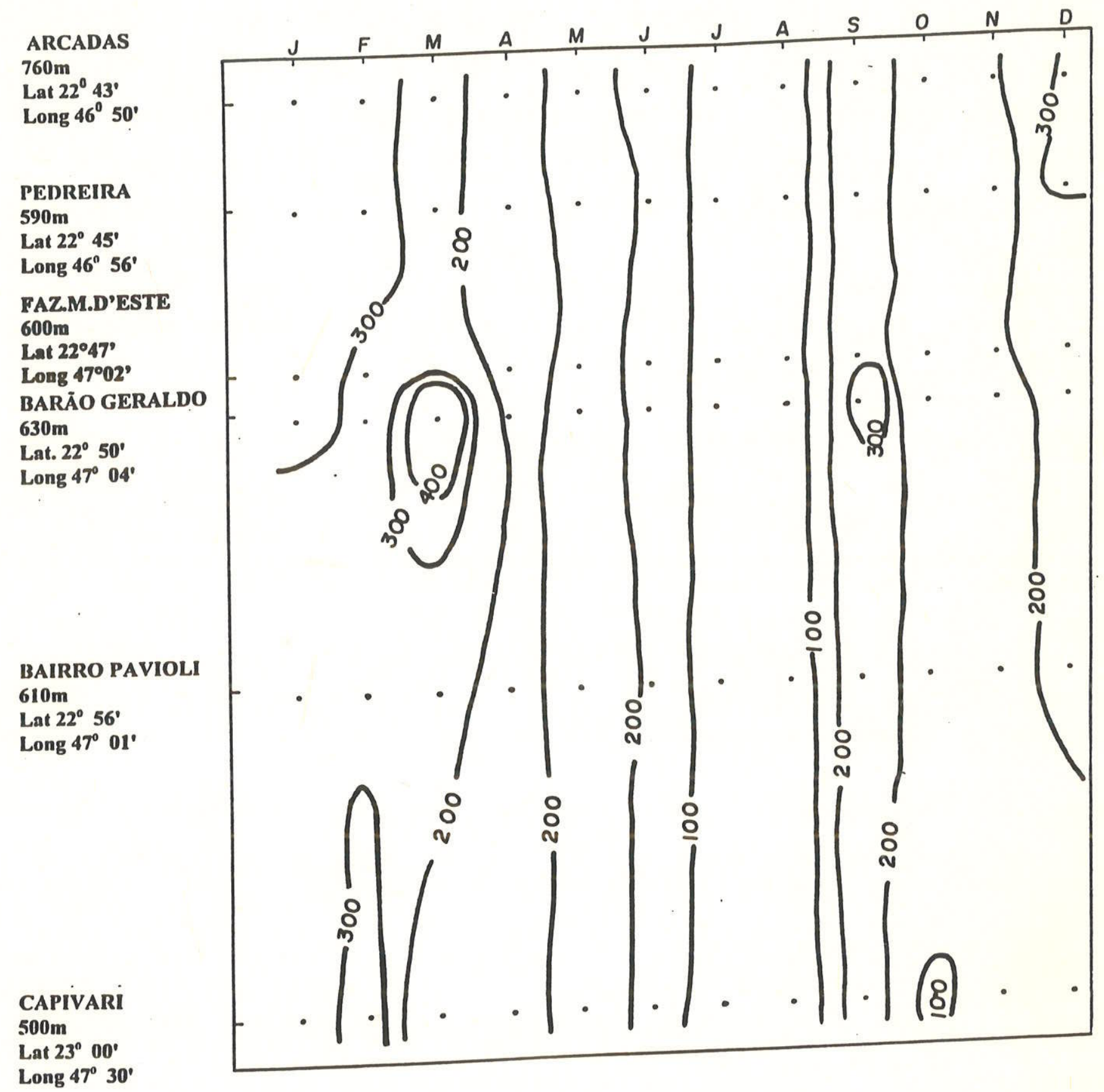

Figura 17 - Variação mensal da precipitação pluviométrica $(\mathrm{mm})$ no transecto Arcadas - Capivari - ano mais chuvoso (1983) 
Em relação às deficiências hídricas, os resultados foram muito pequenos (os maiores valores foram próximos a $10 \mathrm{~mm} / \mathrm{ano}$, no noroeste da área), e portanto não foram consideradas para a espacialização do conjunto dos postos, sendo utilizados apenas nos transectos temporo-espaciais do perfil escolhido.

Foram feitos também transectos em perfis significativos que acusavam a variação dos montantes tanto de evapotranspiração potencial (Figura 20) como excedentes , hídricos (Figura 21) e deficiências hídricas (Figura 22).

\section{a.Evapotranspiração Potencial (Figura 18)}

É o processo físico da vaporização de água, fenômeno que só se efetiva com o consumo de energia, cuja fonte na natureza é a radiação solar. É uma função da quantidade de energia solar disponível, na superfície vegetada a evapotranspiração potencial é mais elevada. Através dos dados de radiação solar da região de Campinas, coletados pelo Instituto Agronômico de Campinas no período de 1956 a 1966, adotados como representativo da área de estudo, o valor édio anual foi de 237 $\mathrm{cal} / \mathrm{cm}^{2} / \mathrm{dia}$, o menor índice aparece em junho com um total médio de $127 \mathrm{cal} / \mathrm{cm}^{2} / \mathrm{dia}$ e o maior índice em dezembro com total médio de $329 \mathrm{cal} / \mathrm{cm}^{2} /$ dia (FUNARI 1984).

$\mathrm{Na}$ área de estudo (clima tropical alternadamente seco e úmido), a evapotranspiração é mais elevada quando a área recebe os maiores montantes de precipitação. Nos trópicos tem-se, grosso modo, um efeito compensatório positivo em relação a evapotranspiração, ou seja, um valor de umidade mais elevada nesse período.

Nessa área, a evapotranspiração oscila entre $900 \mathrm{~mm}$ e $1.050 \mathrm{~mm}$, com uma amplitude em torno de $150 \mathrm{~mm}$ sendo que ela aumenta de leste para oeste. Nesse aspecto surge uma primeira evidência da importância da evapotranspitação para a caracterização das fácies climáticas individualizadas, pois é nítida a diferença espacial dessa distribuição, condicionada em última instância pela altimetria. 


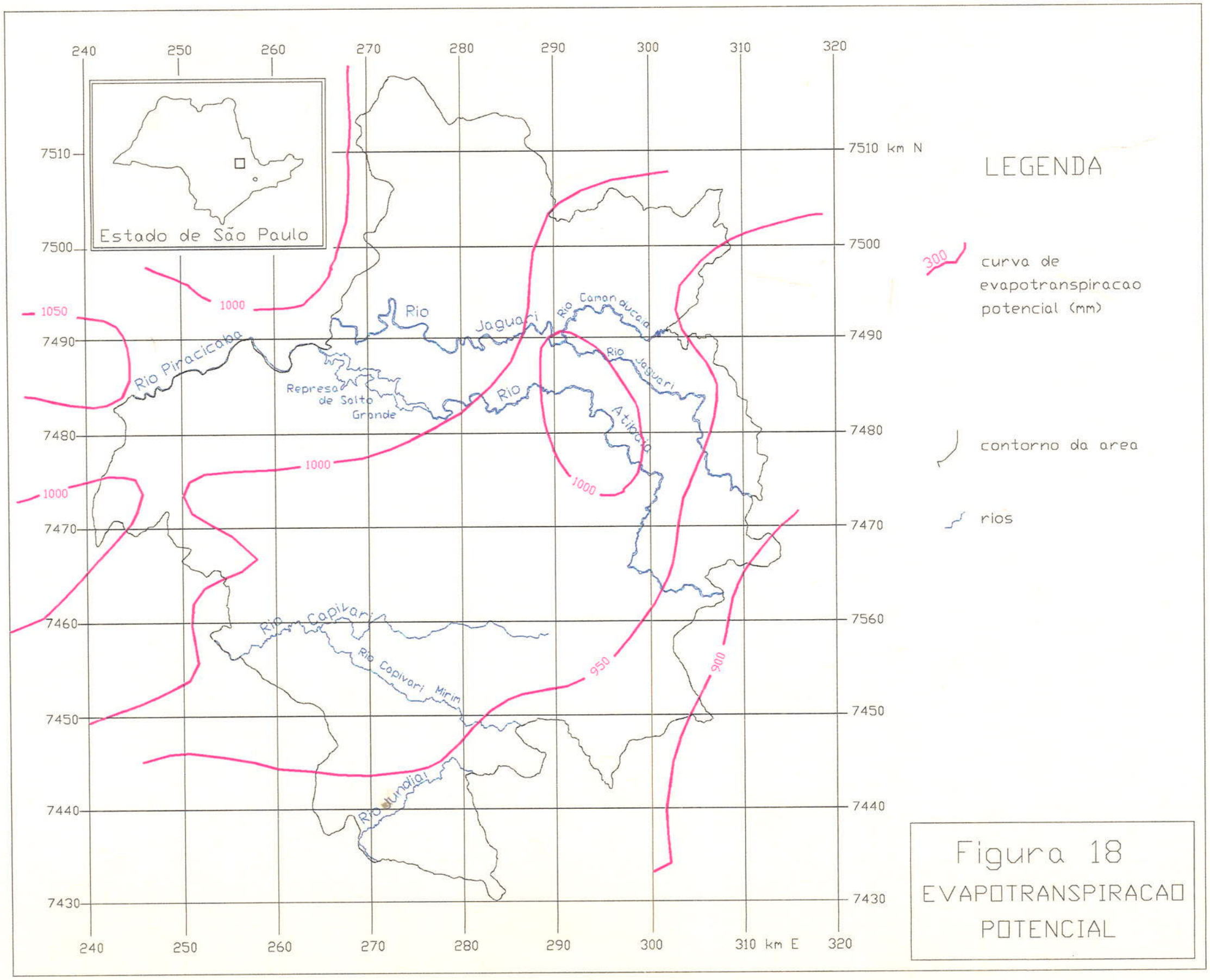


A disponibilidade hídrica em forma de excedentes é o resultado do confronto entre os valores de evapotranspiração e precipitação pluviométrica, ou seja, aquele montante que não foi evapotranspirado é que irá abastecer as águas subterrâneas, os rios, que é utilizado pelas plantas e que está disponível para o uso humano nas mais diferentes finalidades.

$\mathrm{Na}$ área de interesse os excedentes hídricos variam de 300 a $650 \mathrm{~mm}$ com uma amplitude de $350 \mathrm{~mm}$, considerada bastante elevada, devido a pouca distância entre pontos extremos (aproximadamente $60 \mathrm{Km}$ ). Os maiores valores estão a leste da área (porção mais elevada) diminuindo significativamente para oeste.

c.Análise Dos Transectos Temporo - Espaciais Relativos Ao Balanço Hídrico

O objetivo específico da confeção desses transectos foi dar maior consistência a definição das Feições Climáticas e Células Climáticas.

$\mathrm{Na}$ análise do transecto da Evapotranspiração Potencial (Figura 20) é possivel a distinção das Fácies Climáticas, principalmente no período da primavera-verão. Essa distinção se acentua quando são analisados os excedentes hídricos (Figura 21), repetindo-se o período da primavera verão. Nos meses de outono-inverno essa situação é pouco significativa.

Do ponto de vista climático, a área de estudo insere-se em meio tropical alternadamente seco e úmido. Isso implica que, na ocorrência dos maiores valores de Evapotranspiração (primavera-verão) encontram-se as maiores concentrações de chuvas, acontecendo então um efeito de compensação: nesse período perde-se muita umidade, mas as chuvas repõem tais perdas, o que é significativo em termos de recarga de aquífero. 


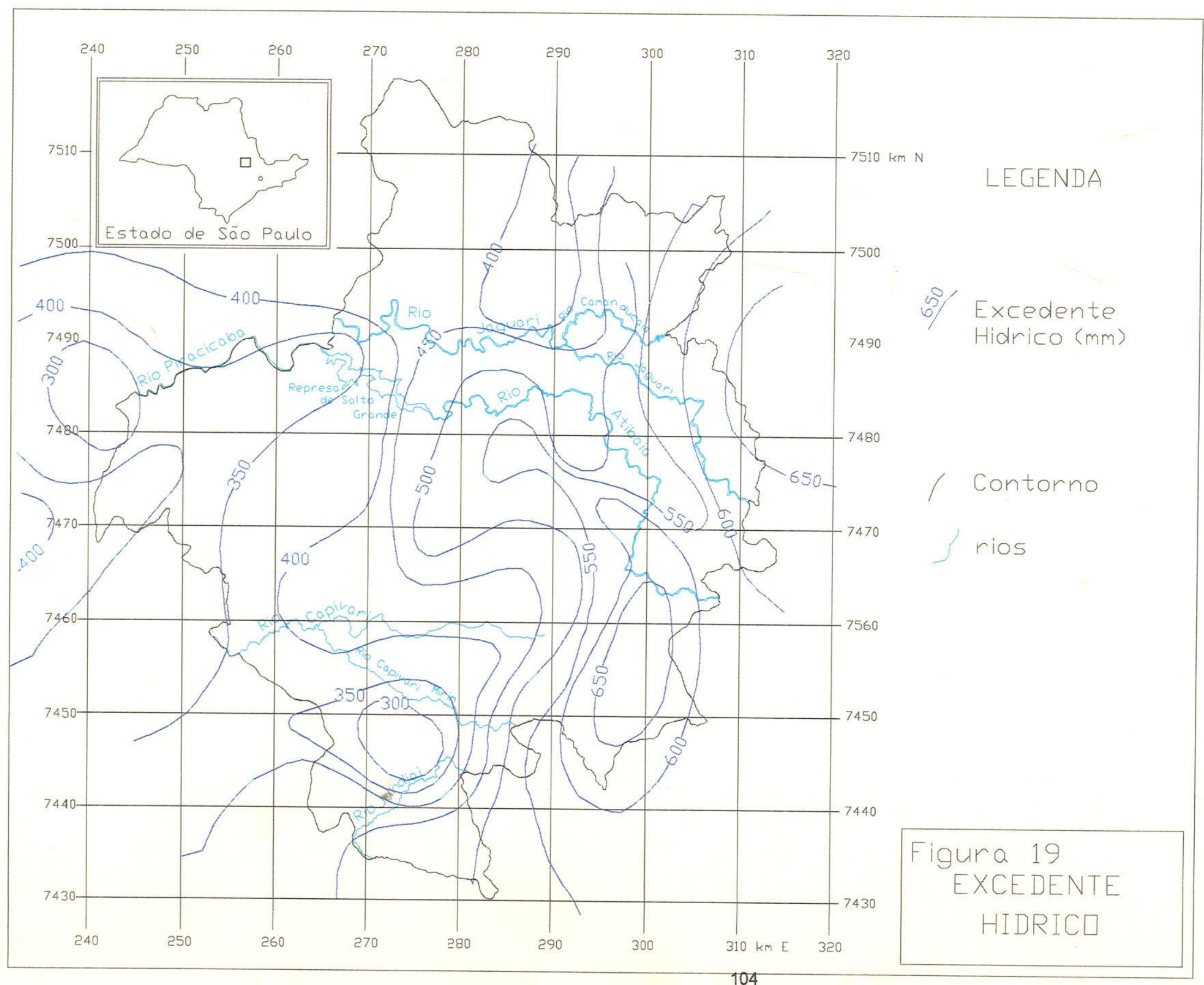




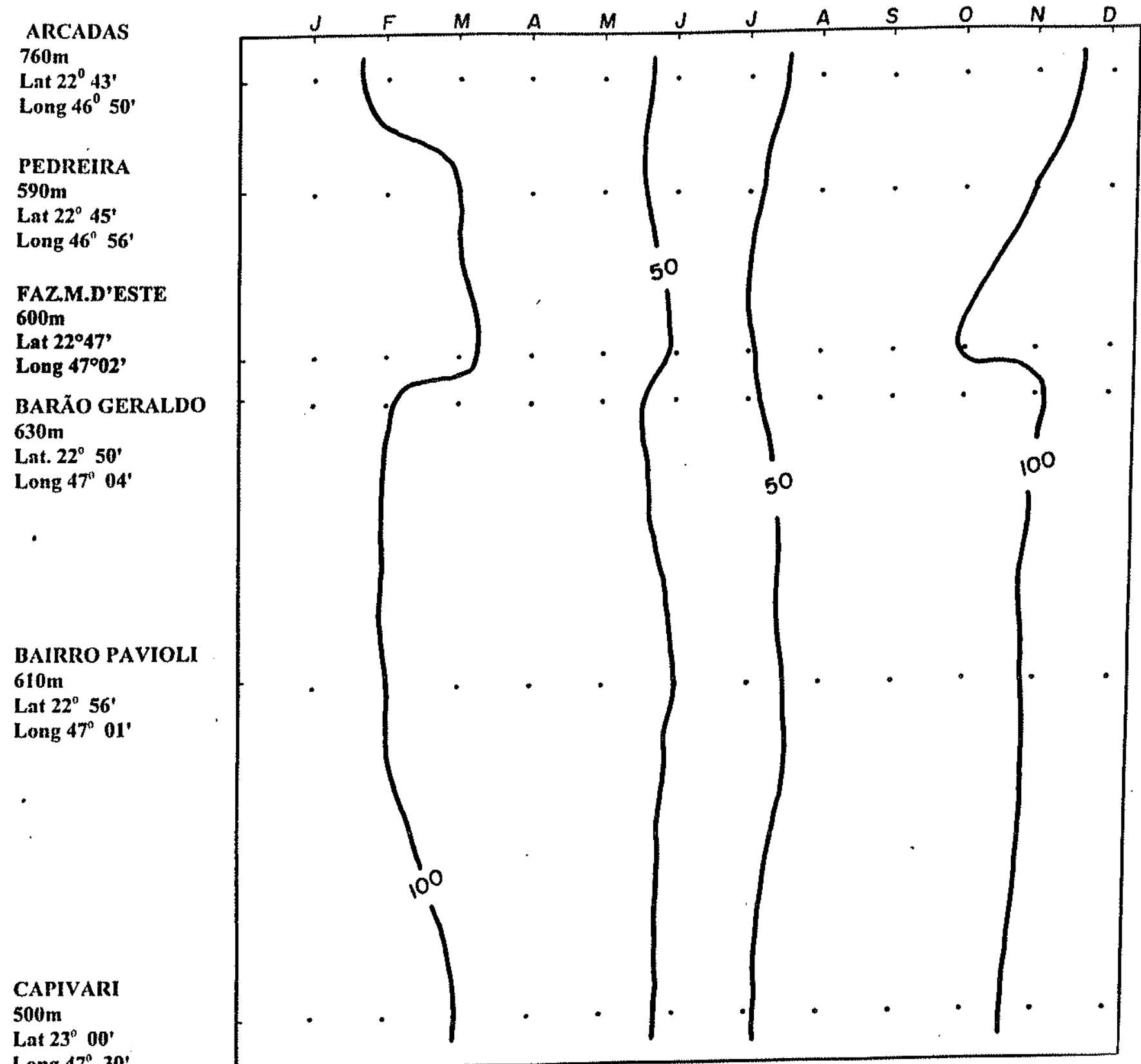

Figura 20 - Variação mensal da evapotranspiração potencial (mm) no transecto Arcadas - Capivari - período 1976 - 1991 


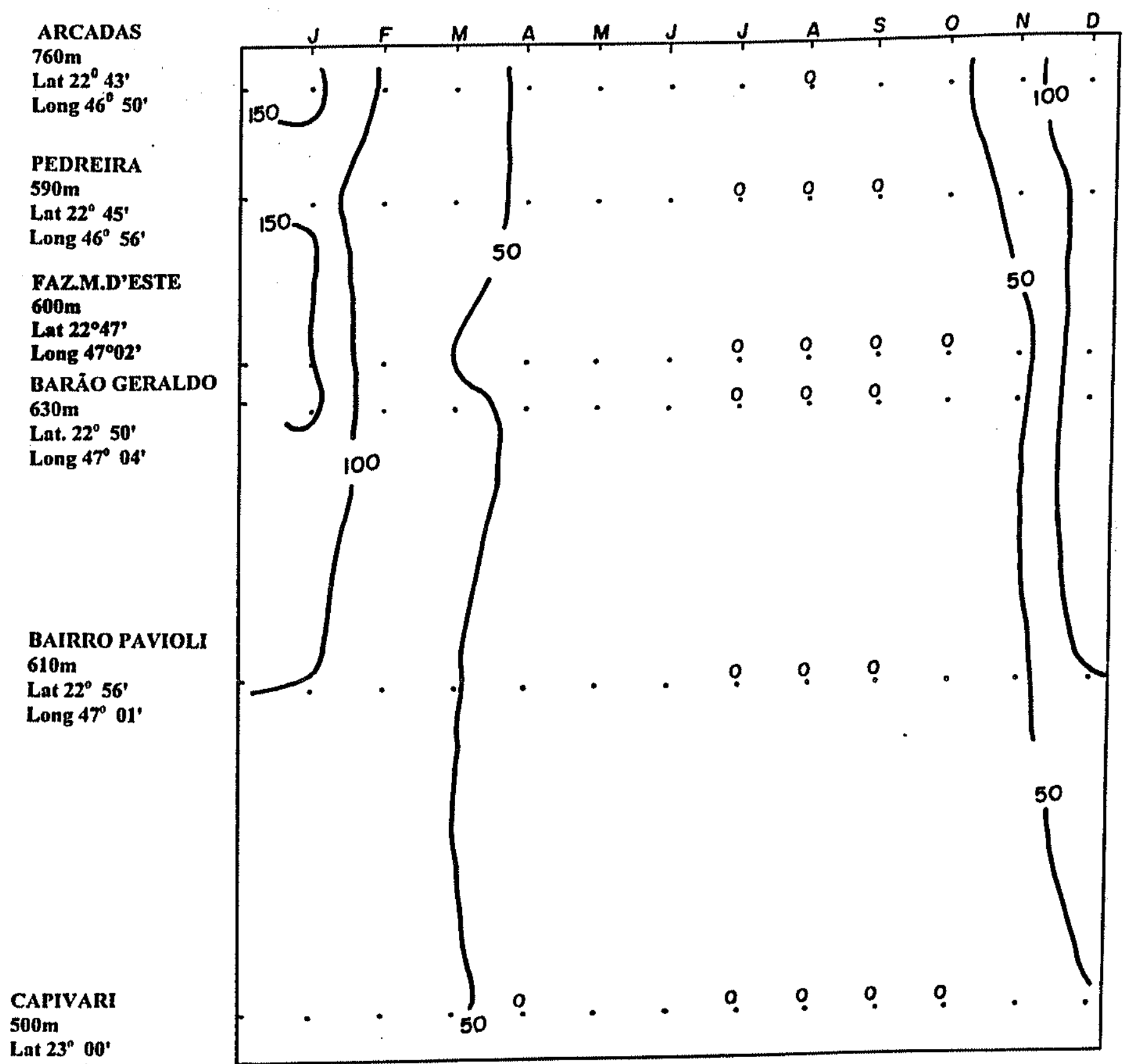

Figura 21 - Variação mensal do excedente hídrico (mm) no transecto Arcadas Capivari - período 1976 - 1991 
A análise do transecto da deficiência hídrica (Figura 22) mostra que esse parâmetro inexiste na primavera verão e são insignificantes no outono-inverno.

\subsubsection{As UNIDADES CLIMÁTICAS}

“É possivel delinear no território paulista dois climas zonais (Figura 23).

Ao sul, na zona subtropical, o clima é controlado pelas massas Tropicais e Polares, individualizando-se sob tipos dos climas permanentemente úmido das margens orientais e subtropicais dos continentes, atacados pela Frente Polar, mas dominados por Sistemas Tropicais Marítimos (em que a área de interesse não se insere nesse escopo).

Ao norte o clima é controlado por sistemas tropicais e equatoriais, que se caracteriza por um clima alternadamente seco e úmido (onde se insere a área de estudo).

Essa divisão foi embasada na atuação percentual das massas de ar (MONTEIRO, 1973). Taxonomicamente o clima zonal (onde está inserida a área de estudo) foi dividido em 02 climas regionais (A1 climas úmidos das costas expostas às massas tropicais e A2 climas tropicais alternadamente secos e úmidos). Esses climas regionais foram subdivididos em 09 unidades, baseados nas variações do ritmo e distribuição quantitativa espacial dos elementos climáticos disponíveis dentro do quadro morfológico.

Nesse escopo, dentre as 09 unidades definidas, a área de estudo está inserida em uma zona de transição entre a Sub-Unidade VI da "PÉRCEE" do Tietê (com a tendência de diminuição dos montantes pluviométrico do centro para sudeste), Feição Climática II, e a unidade Serra da Mantiqueira (IV) nas cabeceiras do rio Piracicaba onde os índices pluviométricos apresentam valores mais elevados como pode ser visto nos mapeamentos pluviométrico e nos transectos (Feição Climática I). No trabalho de MONTEIRO (1973) as feições climáticas foram individualizadas pela análise rítmica das chuvas, através da sua distribuição diária; contudo, neste estudo individualizou-se essas fácies e células climáticas (áreas com maiores afinidades dentro das fácies), utilizando-se principalmente os resultados do Balanço Hídrico (mapeando a 
evapotranspiração potencial, os excedentes e as deficiências hídricas no decorrer do ano), a distribuição temporo-espacial das precipitações pluviométricas e suas associações com as unidades geomorfológicas.

Dentro dessas duas feições climáticas ( e II) individualizaram-se três células climáticas na unidade I e uma na unidade climática II, espacializadas no Mapa Síntese das Unidades Climáticas (Figura 24) e sua legenda (Tabela 11), que contêm os fatores climáticos e os elementos climáticos.

Esse mapeamento síntese é um subsídio importante para o planejamento das atividades humanas pois pode-se definir espacialmente áreas de interesse, e apresentar-se as principais informações de cunho climático e propor ações. 
ARCADAS

$760 \mathrm{~m}$

Lat $22^{\circ} 43^{\prime}$

Long $46^{\circ} 50^{\prime}$

PEDREIRA

$590 \mathrm{~m}$

Lat $22^{\circ} 45^{\prime}$

Long $46^{\circ} 56^{\prime}$

FAZ. M. D'ESTE

$600 \mathrm{~m}$

Lat $22^{\circ} 47^{\circ}$

Long $47^{\circ} 02^{\prime}$

BARÃ̃ GERALDO $630 \mathrm{~m}$

Lat. $22^{\circ} 50^{\prime}$

Long $47^{\circ} 04^{\prime}$

BAIRRO PAVIOLI $610 \mathrm{~m}$

Luat $22^{\circ} 56^{\prime}$

Long $47^{\circ} 01^{\prime}$

CAPIVARI

$500 \mathrm{~m}$

Lat $23^{n} 00^{\prime}$

Long $47^{\circ} 30^{\prime}$

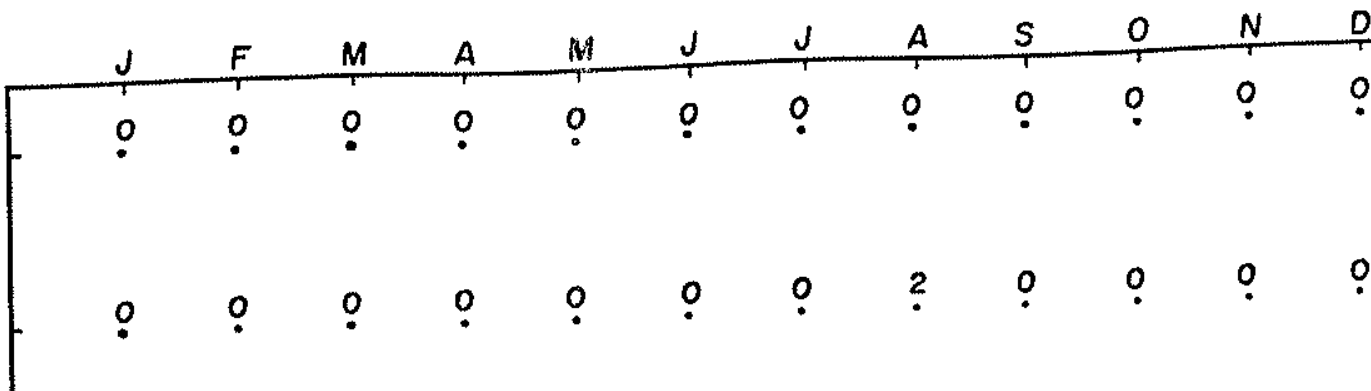

$\begin{array}{llllllllllll}0 & 0 & 0 & 0 & 0 & 0 & 0 & 4 & ! & 0 & 0 & 0 \\ 0 & 0 & 0 & 0 & 0 & 0 & 0 & 2 & 0 & 0 & 0 & 0\end{array}$

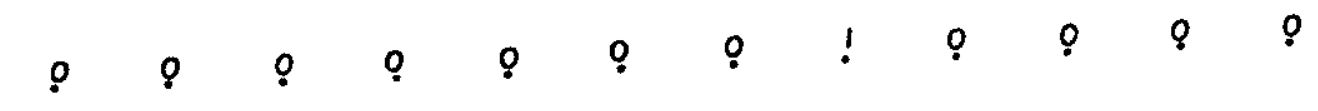

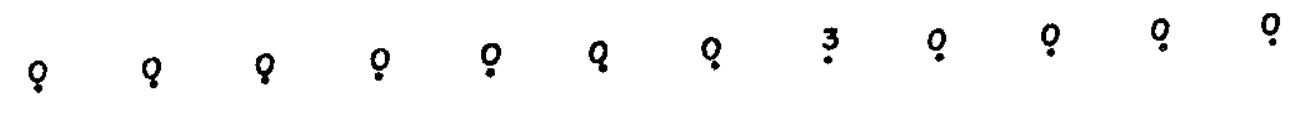

Figura 22 - Variação mensal da deficiência hídrica (mm) no transecto Arcadas Capivari - período 1976 - 1991 


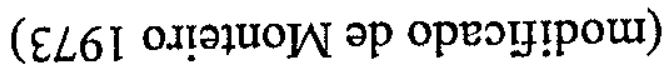

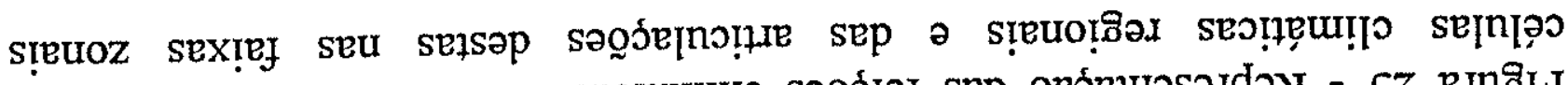

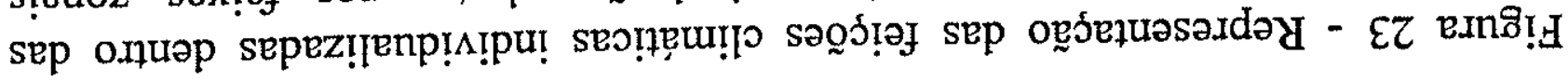

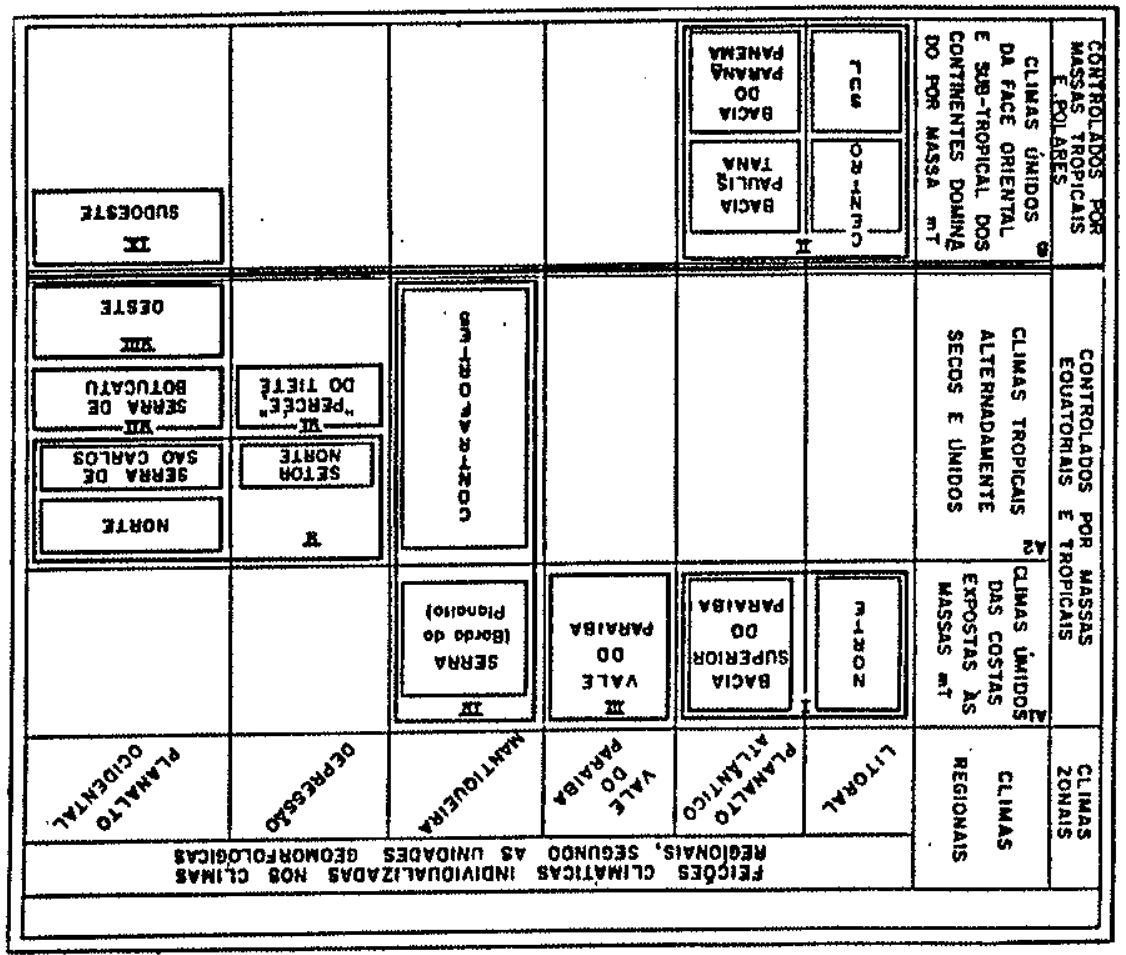

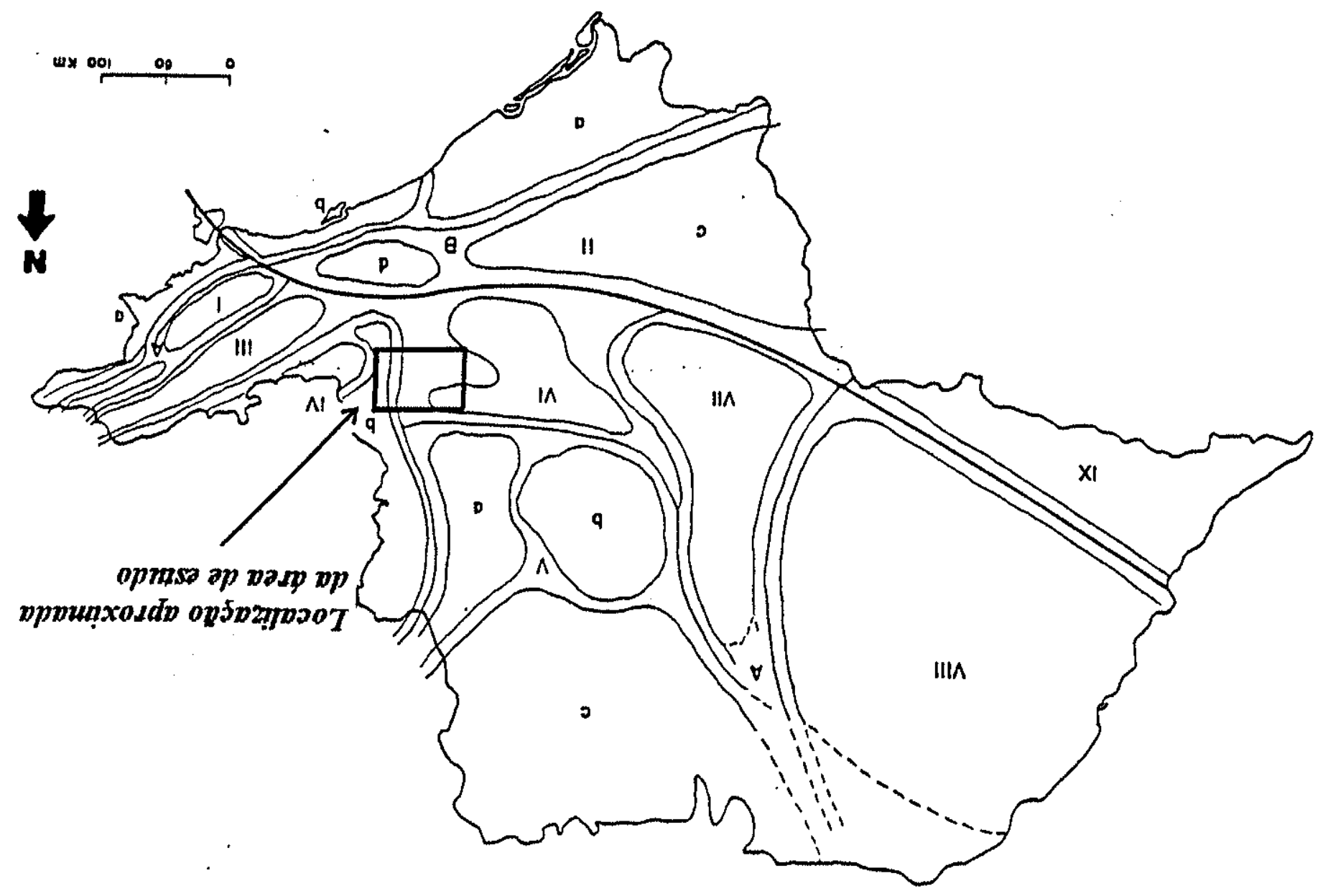




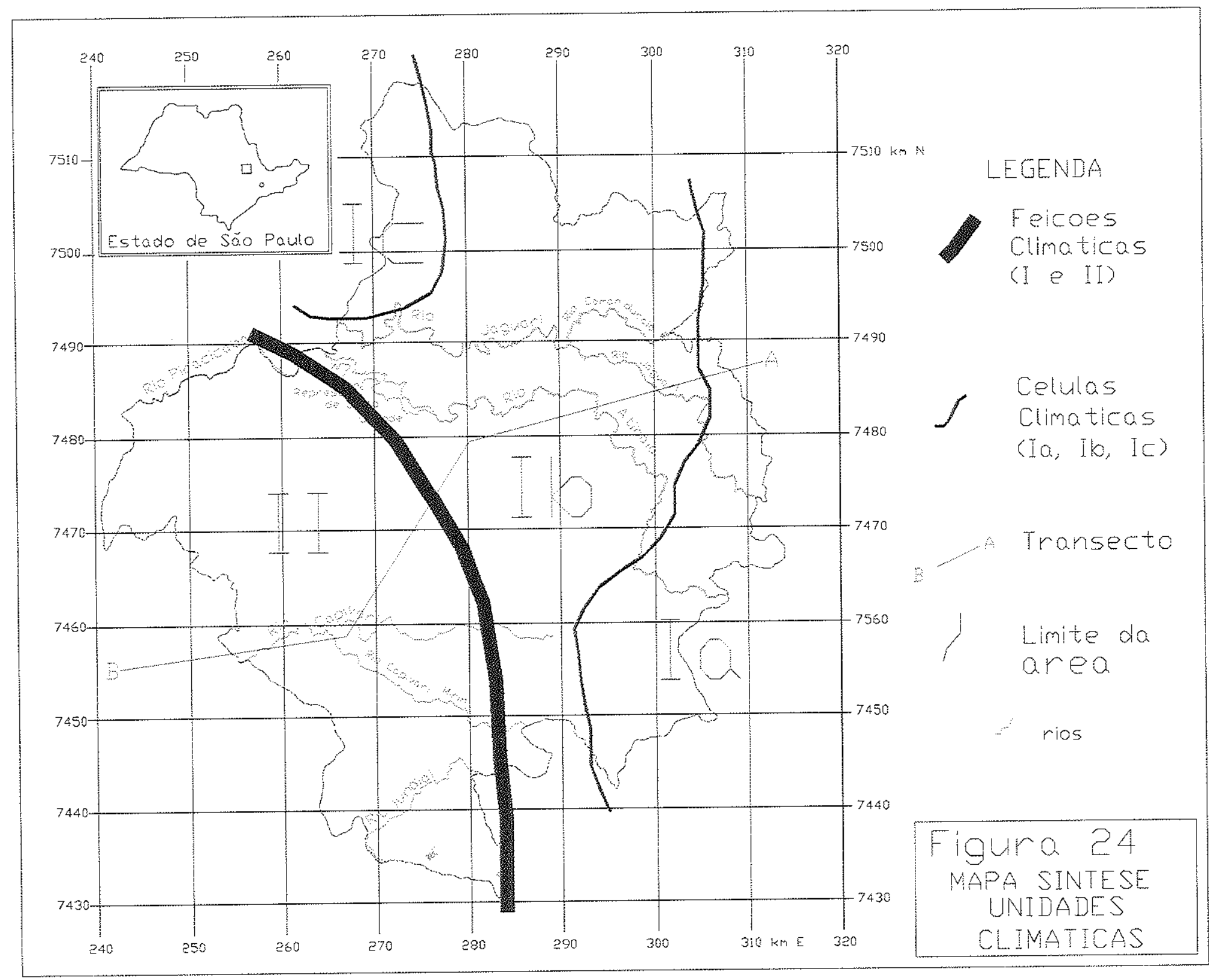

111 
Tabela 11 - Legenda do Mapa de Unidades Climáticas

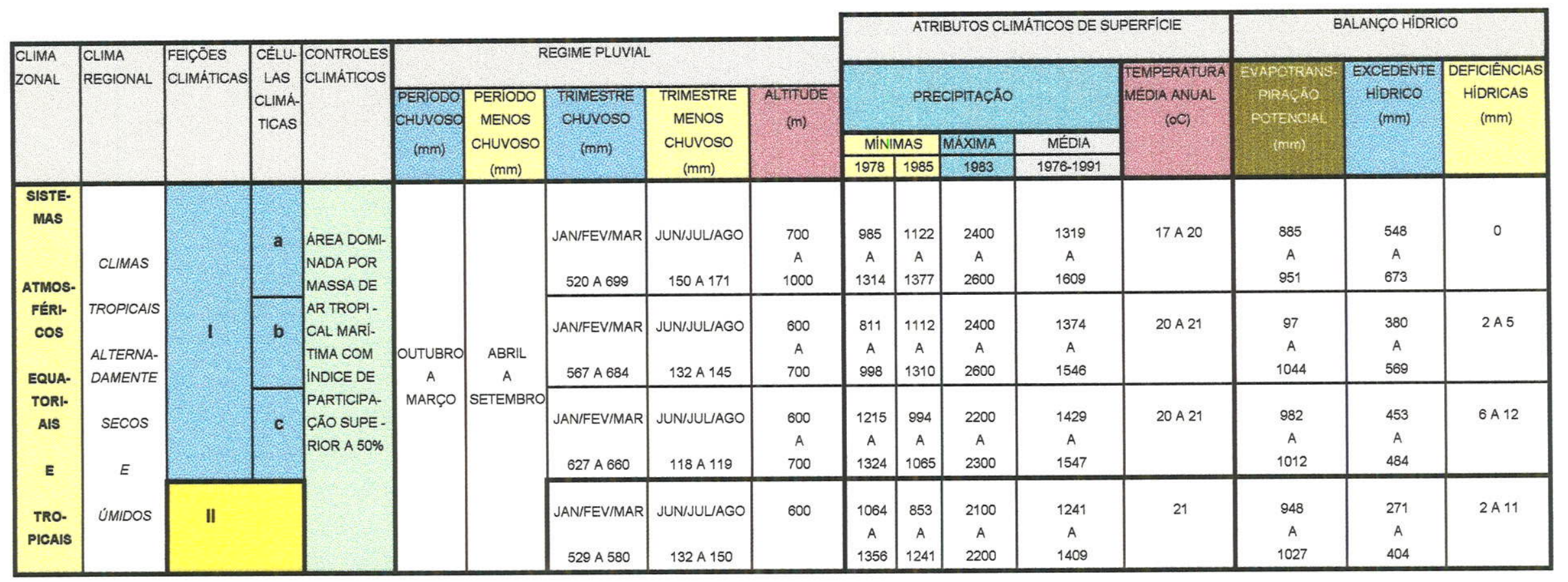




\section{5.ÁGUA SUBTERRÂNEA}

\subsection{CONHECIMENTOS ANTERIORES}

Os estudos regionais, que englobam a região metropolitana, consistem das avaliações hidrogeológicas executadas por DAEE (1982) na Região Administrativa de Campinas e Lopes $(1984,1994)$, no estado de São Paulo e nas bacias hidrográficas dos rios Piracicaba e Capivari.

As avaliações regionais apresentam uma caracterização geral dos sistemas aqüíferos (descritos aqui somente os existentes na área de estudo), constituindo uma referência aos estudos de maiores escalas.

$\mathrm{Na}$ tabela 12, estão sintetizados os resultados desses estudos, com a caracterização regional dos sistemas aqüíferos que são encontrados na região metropolitana.

A caracterização hidroquímica das águas subterrâneas dos sistemas aqüíferos do estado de São Paulo é executado por Campos (1993).

Esse autor classificou as águas do Sistema Aqüífero Tubarão, como predominantemente bicarbonatadas sódicas, seguida das bicarbonatadas cálcicas e cálcio-sódicas, cujos teores salino e do íon sódio parecem possuir uma tendência regional de evolução hidrogeoquímica no sentido leste-oeste; no entanto, o comportamento distinto do íon cloreto sugere zonas distintas de circulação da água subterrânea neste sistema aqüífero. O Cristalino apresenta águas de composição bicarbonatadas cálcicas, seguido da bicarbonatada cálcio-sódicas e bicarbonatadas sódicas.

Para a região de estudo, o mapa de qualidade química das águas subterrâneas indica duas zonas distintas: as águas bicarbonatadas sódicas predominando na maior parte da área, e no município de Campinas, águas bicarbonatadas cálcicas, com teores de resíduo seco da ordem de $200 \mathrm{mg} / 1$.

A análise para vários tipos de uso determinou duas classificações: a primeira, que abrange a maior parte da área de estudo considera as águas potáveis, com média a alta salinidade e quantidade de sódio elevada, não sendo recomendável o uso em solos de 
textura fina e com pouca capacidade de lixiviação. Na parte do Sistema Aqüífero Cristalino e próximo ao contato com o Sistema Aqüifero Tubarão, as águas são potáveis, com baixa a média salinidade e quantidade de sódio, recomendada para irrigação na maioria das culturas e solos de boa textura e com boa capacidade de lixiviação.

O trabalho de Diogo et all. (1984) apresenta uma análise das características hidráulicas e hidroquímicas do Grupo Tubarão no Estado de São Paulo. As características hidráulicas determinadas para esse sistema aqüífero foram uma variação de 0,002 a $7,5 \mathrm{~m}^{3} / \mathrm{h}$ por metro de rebaixamento de capacidade específica, transmissividade da ordem de 0,03 a $153 \mathrm{~m}^{2} /$ dia e permeabilidade média dos arenitos em 0,003 a 3,1 m/dia. Em relação à hidroquímica, as águas variam de bicarbonatadas - cálcicas a sódicas, fracamente salinas.

Segundo esses autores, distinguem-se duas zonas distintas de circulação de água subterrânea, em que as zonas mais permeáveis e com águas menos mineralizadas estão associadas às unidades inferior e superior do Subgrupo Itararé e à Formação Aquidauana. A região de Campinas está inserida na área com transmissividades superiores a $10 \mathrm{~m}^{2} / \mathrm{dia}$, que correspondem às essas unidades do Subgrupo Itararé.

Stevaux et all. (1987) analisam os sistemas deposicionais do Subgrupo Itararé na Bacia Hidrográfica do Rio Capivari, e sugere um modelo para prospecção de água subterrânea, determinando três tipos de aqüiferos: o primeiro (I), corresponde aos conglomerados e arenitos grosseiros do sistema de leques aluviais, apresentando uma vazão entre 1 a $5 \mathrm{~m}^{3} / \mathrm{h}$ e profundidade superior a 300 metros. Os depósitos de origem turbidítica, de natureza mais errática, não foram considerados aqüiferos pelos autores devido sua baixa produtividade. O aqüífero II, de melhor produtividade na área, apresenta vazões que chegam a $35 \mathrm{~m}^{3} / \mathrm{h}$ e são os sedimentos originados de frente deltáica. O aqüífero III, o mais produtivo do Subgrupo Itararé, possui geometria tabular de grande extensão, ocorrente ao norte de Capivari, e apresentando vazões de até $100 \mathrm{~m}^{3} / \mathrm{h}$ (correspondentes às formações Tatuí e Tietê).

$\mathrm{Na}$ Região Metropolitana de Campinas, o Instituto Geológico desenvolveu estudo de maior detalhe, na escala 1:50.000 nos municípios de Campinas, Jaguariúna, Cosmópolis, Holambra, Nova Odessa, Paulínia, Hortolândia, Americana e Sumaré.

No Município de Campinas, o Sistema Aqüífero Cristalino apresentou valores de capacidades específicas entre 0,09 a $1,32 \mathrm{~m}^{3} / \mathrm{h}$ por metro de rebaixamento, e a maior 
produtividade encontrada em poços situados próximos à feição vale. No manto de alteração, os valores de capacidade específica variaram entre 0,15 e $0,35 \mathrm{~m}^{3} / \mathrm{h}$ por metro de rebaixamento. Nos diabásios, obtiveram-se valores de capacidades específicas variando de 0,18 a $1,59 \mathrm{~m}^{3} / \mathrm{h}$ por metro de rebaixamento e as maiores produtividades dos poços localizados na feição geomórfica vale. O Sistema Aqüífero Tubarão Subgrupo Itararé, no Município de Campinas (IG 1993), a capacidade específica dos ,poços apresentam valores entre 0,08 e $0,30 \mathrm{~m}^{3} / \mathrm{h}$ por metro de rebaixamento. A vulnerabilidade natural é considerada média nos sedimentos ocorrentes nesse município. Os aqüíferos aluvionares são considerados de alta vulnerabilidade à contaminação antrópica.

Nos demais municípios estudados pelo Instituto Geológico na área os sistemas aqüíferos são caracterizados pelos seguintes valores:

Sistema Aqüífero Cristalino - capacidade específica média de $0,56 \mathrm{~m}^{3} / \mathrm{h}$ por metro de rebaixamento; vazão média de $7,6 \mathrm{~m}^{3} / \mathrm{h}$.

Sistema Aqüífero Tubarão - capacidade específica média de $0,21 \mathrm{~m}^{3} / \mathrm{h}$ por metro de rebaixamento; vazão média de $7,7 \mathrm{~m}^{3} / \mathrm{h}$. As áreas mais produtivas estão associadas às ocorrências de sedimentos mais arenosos do aqüífero.

Sistema Aqüífero Diabásio - capacidade específica média de $0,28 \mathrm{~m}^{3} / \mathrm{h}$ por metro de rebaixamento; vazão média de $5,9 \mathrm{~m}^{3} / \mathrm{h}$;

Poços Mistos - Tubarão e Diabásio: capacidade específica média de $0,46 \mathrm{~m}^{3} / \mathrm{h}$ por metro de rebaixamento, vazão média de $8,2 \mathrm{~m}^{3} / \mathrm{h}$; Diabásio e Cristalino: capacidade específica média de $0,16 \mathrm{~m}^{3} / \mathrm{h}$ por metro de rebaixamento; vazão média de $6,9 \mathrm{~m} / \mathrm{h}$; Tubarão e Cristalino, capacidade específica média de $0,11 \mathrm{~m}^{3} / \mathrm{h}$ por metro de rebaixamento e vazão média de $6,0 \mathrm{~m}^{3} / \mathrm{h}$; Tubarão, Diabásio e Cristalino: capacidade específica média de $0,11 \mathrm{~m}^{3} / \mathrm{h}$ por metro de rebaixamento e vazão média de $5,2 \mathrm{~m}^{3} / \mathrm{h}$. Com base nessas informações e de sua distribuição espacial, foram determinadas zonas de produtividade, fundamentadas em parâmetros hidrogeológicos e estruturais da região avaliada. A disponibilidade do recurso hídrico subterrâneo nesses estudos foi calculada por município, bem como a análise do perfil do usuário e aspectos construtivos.

Em Sumaré (Groundwater - Hidrogeologia e Engenharia 1984) obteve-se os valores de capacidade específica entre 0,01 a $0,50 \mathrm{~m}^{3} / \mathrm{h}$ por metro de rebaixamento para 
o Sistema Aqüífero Tubarão, sendo estimadas uma reserva ativa de 12,272 milhöes de $\mathrm{m}^{3}$ e uma reserva potencial anual de 32,34 milhões de metros cúbicos para o aqüifero nessa área. 
Tabela 12 - Sintese da bibliografia existente sobre a hidrogeologia regional.

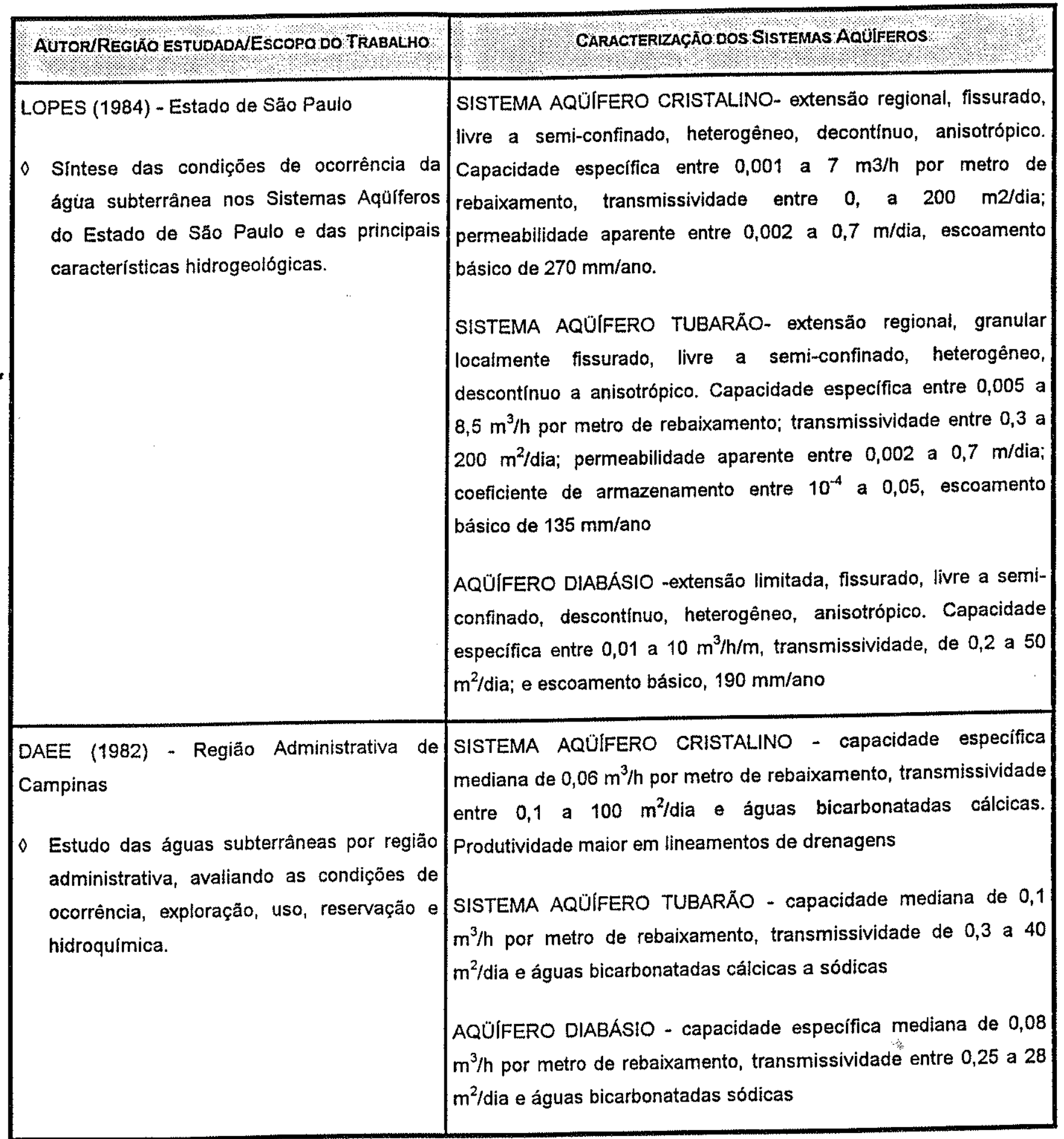


Tabela 12 (cont.) - Sintese da bibliografia existente sobre a hidrogeologia regional.

\begin{tabular}{|c|c|}
\hline AUTOR/REGIAO ESTUDADAJESCOPO OO TRABACHO & CARACTERIZAGAODOS SISTEMAS ACOIFEROS: \\
\hline $\begin{array}{l}\text { LOPES (1994) - Bacias dos rios Piracicaba e } \\
\text { Capivari } \\
\text { Caracterização das condições de ocorrência } \\
\text { das, águas subterrâneas, diagnóstico da } \\
\text { situação atual, disponibilidade } \\
\text { perspectivas de aproveitamento. }\end{array}$ & 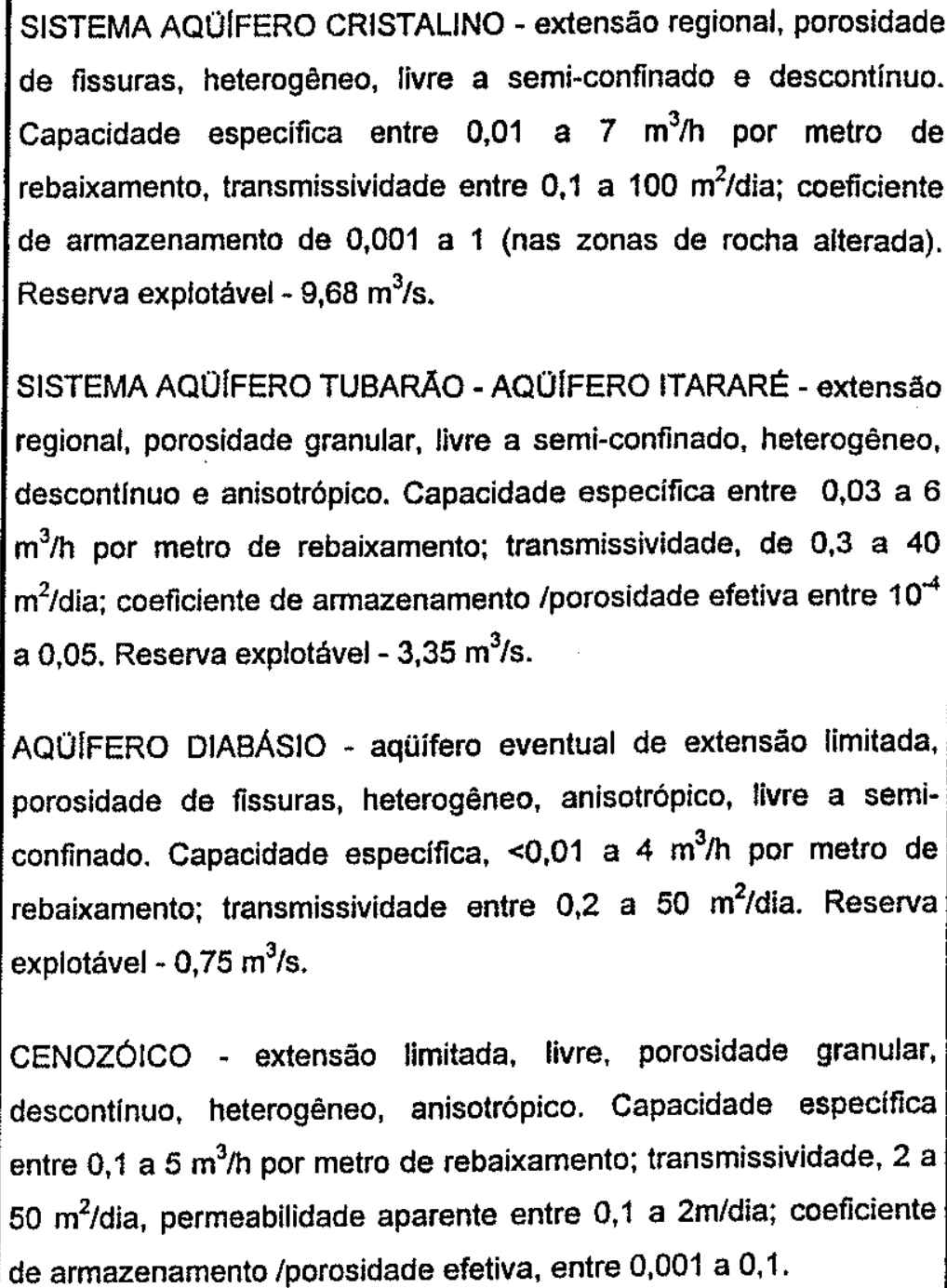 \\
\hline
\end{tabular}




\subsection{CONDIÇÕES DE OCORRÊNCIA}

\subsubsection{Geometria dos Sistemas Aqüíferos}

$\mathrm{Na}$ Região Metropolitana de Campinas distinguem-se dois grandes sistemas aqüíferos regionais: o Sistema Aqüifero Tubarão, representado aqui pelos sedimentos 'permo-carbonífero do Subgrupo Itararé, e o Sistema Aqüífero Cristalino, composto por rochas ígneas e metamórficas de naturezas granítica e gnáissica do Complexo Itapira, Granitóide Jaguariúna e Granitos Morungaba e Itu, de idade precambriana e cambroordoviciana. Subordinadamente, as rochas de diabásio da Formação Serra Geral constituem-se em aqüiferos locais, limitantes quanto a sua extensão: são corpos pequenos distribuídos irregularmente por toda a área de estudo e às diversas profundidades. Os maiores corpos aflorantes encontram-se na parte central do município de Campinas e ao norte da área em Santo Antonio da Posse.

\subsubsection{Sistema Aqǘfero Cristalino}

O Sistema Aqüifero Cristalino está aflorante na porção leste da Região Metropolitana de Campinas, ocupando uma área de $1117 \mathrm{Km}^{2}$ e comportando os municípios de Vinhedo, Valinhos, Pedreira e Jaguariúna e partes de Campinas, Indaiatuba e Santo Antonio da Posse.

Em termos geomorfológicos, esse sistema situa-se no Planalto de Jundiaí (Planalto Atlântico), de relevo acidentado e possuidor das maiores altitudes e declividades da área de estudo.

As rochas componentes (gnaisses diversos e granitos intrusivos) apresentam diversos tipos de fraturamentos, que condicionam o armazenamento e transmissão da água subterrânea em terrenos cristalinos. As Zonas de Cisalhamento Campinas e Valinhos constituem-se das estruturas mais notáveis da área: possuem direção NE e largas faixas de rochas milonitizadas. As mudanças abruptas das trajetórias dos rios Jaguari e Atibaia praticamente denunciam o fenômeno de movimentação dessas zonas. 
Secundariamente, as falhas normais de direção NE e NS e as falhas transcorrentes e cavalgamento, de sentido NW e EW são vistas na parte do extremo leste e norte da área. Em geral, o Sistema Aqüífero Cristalino apresenta-se bastante fraturado: praticamente todas as drenagens estão condicionadas às estruturas do terreno.

Nas áreas de ocorrência das zonas de cisalhamento e na área entre elas, a direção predominante N40E (aproximada) de fotolineamentos são concordantes a essas estruturas (IG 1993).

$\mathrm{Na}$ parte central e à oeste, o Sistema Aqüífero Cristalino é encoberto pelos sedimentos do Subgrupo Itararé, onde se inicia a Bacia Sedimentar do Paraná na área - de estudo.

A Figura 25 configura o possível contorno do embasamento cristalino na bacia.

Inicialmente, há um caimento gradacional logo após o contato com os sedimentos do Subgrupo Itararé, em toda a extensão da borda da bacia, seguindo também a direção desse contato (nordeste).

$\mathrm{Na}$ parte central e oeste da área, os desníveis topográficos do cristalino são notados, revelando uma superfície bastante acidentada. Existem altos estruturais (a mais alta chegando à cota topográfica de $600 \mathrm{~m}$ dentro do Subgrupo Itararé), dispostos em direção NE, indicando regiões mais elevadas e possíveis estruturas nessa direção. $\mathrm{Na}$ parte norte e principalmente à sudoeste da área de estudo, é nítida a presença de "baixos estruturais".

$\mathrm{Na}$ área da bacia hidrográfica de Capivari (município de Monte Mor), o baixo estrutural observado atinge profundidades consideráveis. A análise dos perfis de poços tubulares profundos indicam a existência de sedimentos abaixo da cota topográfica de $100 \mathrm{~m}$, ou espessuras do pacote sedimentar da ordem de 500 metros.

É interessante observar em superficie, a concordância do baixo estrutural, com a presença de sedimentos lamíticos do Subgrupo ltararé, há mudanças bruscas do tipo de relevo para colinas pequenas em direção EW.

$\mathrm{Na}$ parte norte, as evidências superficiais não são nítidas em uma primeira análise. As descontinuidades EW existentes na Figura 25 delimitam os blocos estruturais de alta e baixas elevações. 


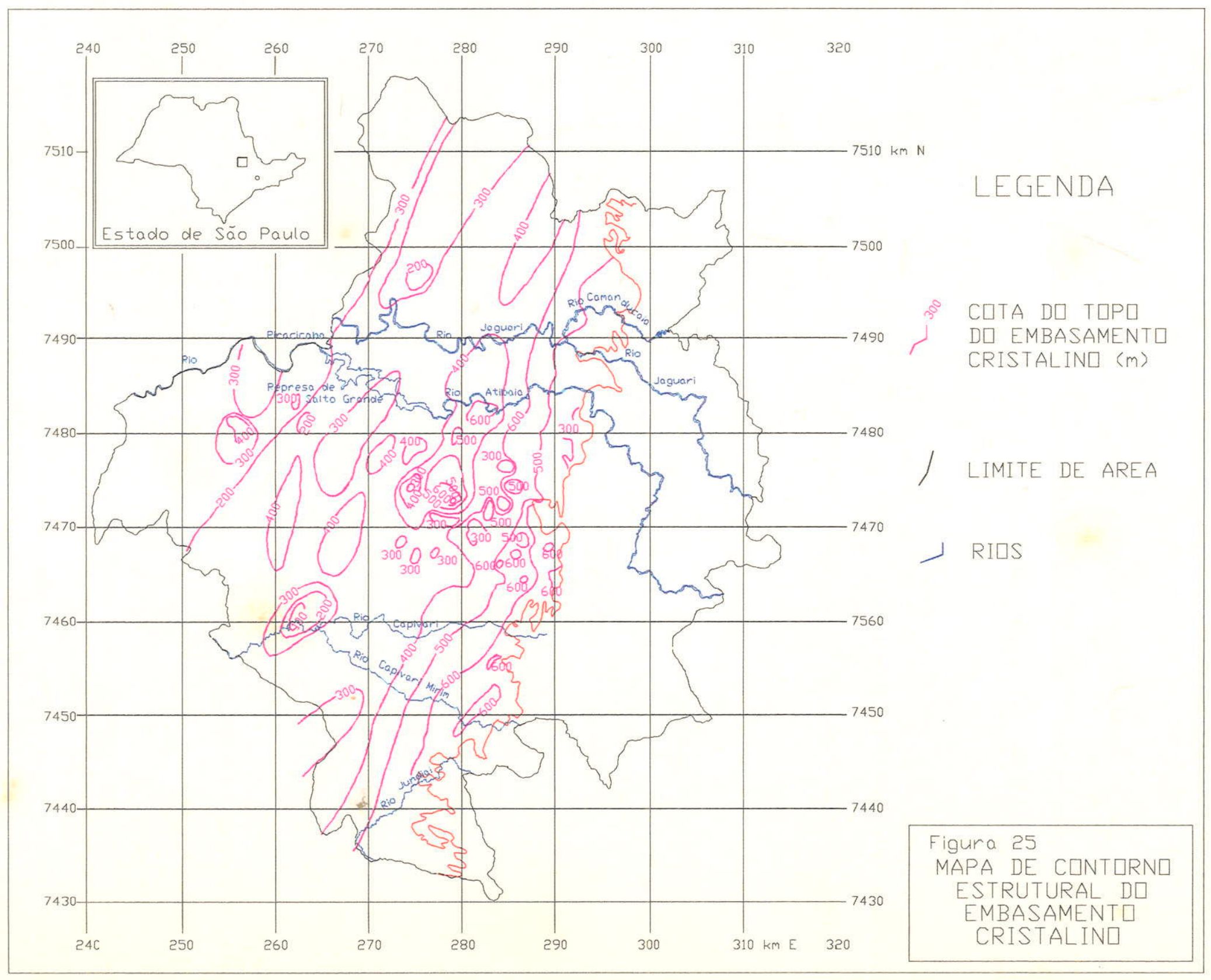


Estas configurações do contorno do cristalino sotoposto ao Subgrupo Itararé, determinadas pela análise dos perfis geológicos dos poços tubulares profundos, são concordantes aos blocos estruturais definidos por Pires Neto (1996). Os baixos estruturais existentes na porção norte e sudoeste da área de estudo e o alto estrutural na parte central, seriam correspondentes à parte limítrofe sul do Bloco Pirapitingui, Bloco Mumbuca e ao Bloco Americana, respectivamente.

‘ Na porção sul da área de estudo o lineamento Porto Feliz - Jacutinga delimita o Bloco Estrutural Capivari do Bloco Viracopos - Indaiatuba, que por sua vez é limitado em sua parte norte pelo Bloco Americana (Figura 26) e leste pelo Bloco Mumbuca.

Na parte aflorante do cristalino, há a presença do Bloco Campinas, definido pelo - lineamento - Araçoiaba - Jacutinga e Zona de Cisalhamento de Valinhos, do Bloco Jaguariúna no extremo nordeste; Bloco Jundiaí e Itu ao sul da área (Pires Neto 1996).

O manto de alteração nas rochas cristalinas apresenta-se nesse aquífero com espessuras variando de 0 a $50 \mathrm{~m}$. Sua composição granulométrica varia de argilosa a arenosa, dependendo da composição mineral e textural da rocha mãe, e caracteriza-se como material friável, não consolidado.

A Figura 27 demonstram a distribuição espacial desses sedimentos.

Os maiores valores de espessura do manto de alteração ocorrem no contato entre - Embasamento Cristalino e a Bacia Sedimentar do Paraná e nas rochas gnáissicas do Complexo Itapira, principalmente na parte sudeste e centro-leste da área.

Essas ocorrências do manto de alteração são encontradas nas superfícies mais arrasadas do cristalino: os tipos de relevo predominantes são as colinas e morrotes e morros e morrotes. As rochas graníticas possuem a maior resistência ao intemperismo físico e químico em detrimento dos gnaisses; conseqüentemente apresentam os terrenos de maiores elevações topográficas e os relevos mais acidentados (escarpas), como também os mais baixos valores de espessura de manto de alteração.

As rochas do Complexo Itapira apresentam maiores números de espessura do manto, cuja distribuição espacial segue a disposição dessas litologias na área: uma faixa alongada de direção nordeste, justamente entre as Zonas de Cisalhamento Campinas e Valinhos. 


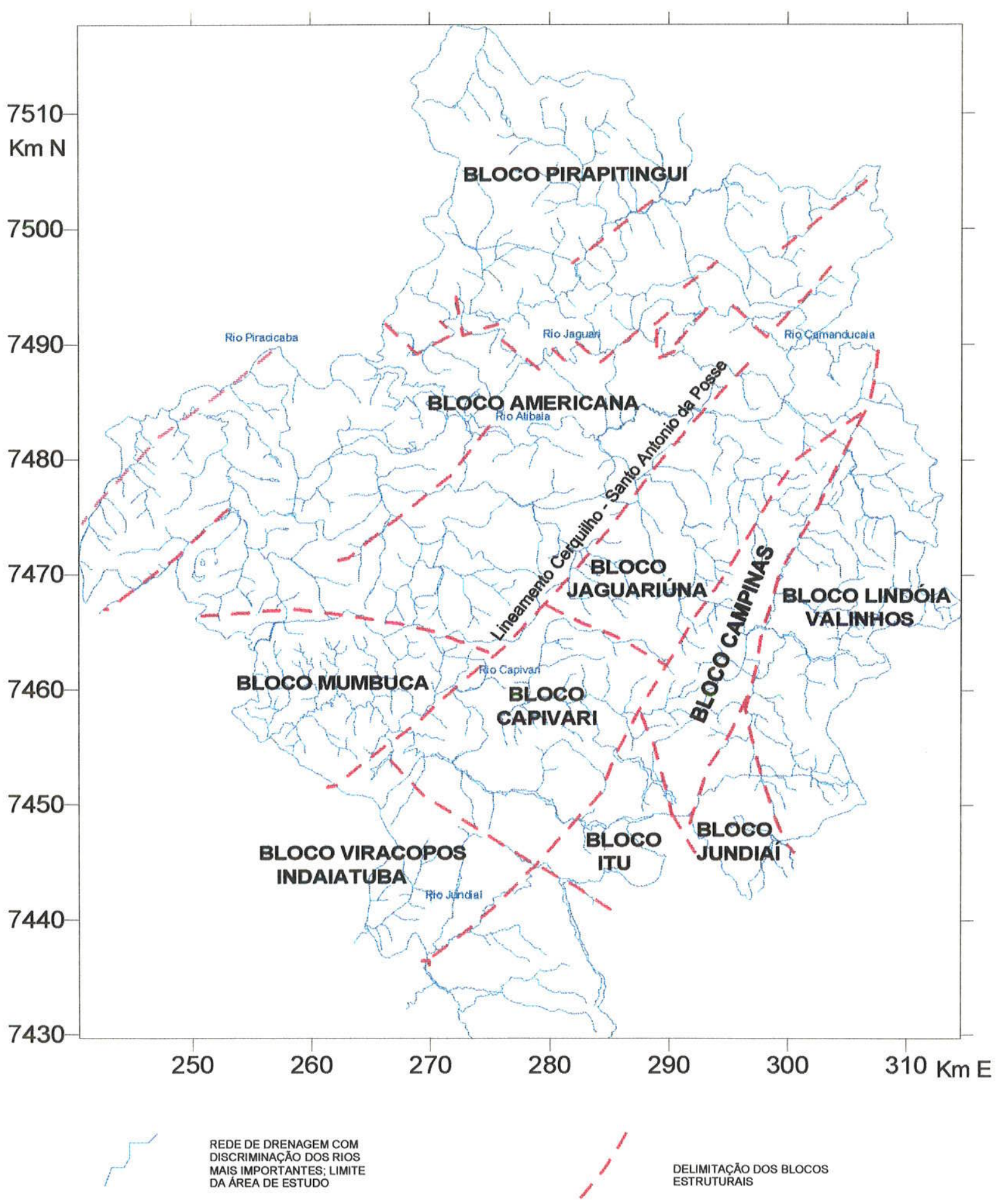

Figura 26 - A situação dos blocos estruturais na Região Metropolitana de Campinas definidos por Pires Neto (1996) 


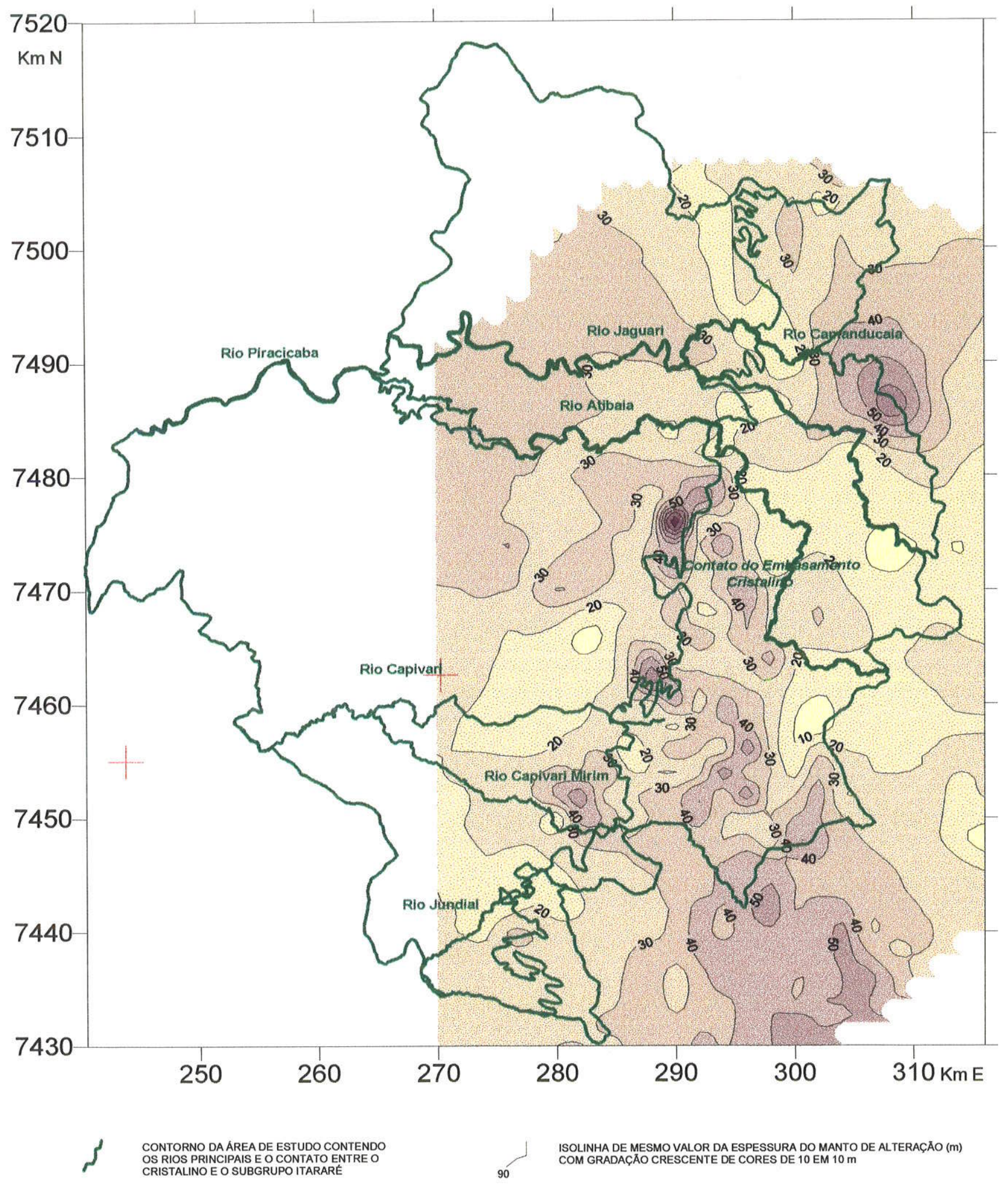

Figura 27 - Distribuição espacial do manto de alteração no embasamento cristalino na Região Metropolitana de Campinas 
Ao sul do embasamento cristalino, as maiores espessuras do manto se extende para sudeste, abrangendo os municípios de Valinhos e Vinhedo, formando uma outra faixa, de direção noroeste. Essa tendência direcional das espessuras consideráveis do manto aparece também na porção central e no extremo norte da área, e provavelmente deve estar relacionada às grandes estruturas de direção noroeste existentes na região.

\subsubsection{Sistema Aquífero Tubarão: Aquífero Itararé}

O Sistema Aqúífero Tubarão é ocorrente na porção centro-oeste e à oeste da Região Metropolitana de Campinas, em contato discordante e erosivo com o embasamento cristalino.

Os sedimentos de Subgrupo Itararé na região representariam ambientes deposicionais distintos: as associações faciológicas de sedimentos pelíticos (ritmitos e diamictitos, lamitos com seixos) seriam depositados em ambiente de plataforma, como correntes de turbidez e produtos de retrabalhamento de depósitos glaciais em ambiente marinho; as associações de arenitos são resultantes de deposição de sedimentos em sistemas deltáicos. Essas litologias apresentam-se muito litificados e algumas vezes com estruturas rúpteis.

Os sedimentos lamíticos possuem maior área aflorante na região, geralmente formados por relevos originários de processos de dissecação (colinas pequenas). Em geral, os arenitos afloram nos topos, na parte superior das vertentes ou em relevos de formas mais suaves (as colinas amplas, médias e amplas com topos subhorizontalizados).

A espessura dos sedimentos aumenta para oeste, em direção ao centro da Bacia Sedimentar do Paraná. No entanto, as variações de espessura dos sedimentos são concordantes com a morfologia do embasamento cristalino: assim, as maiores espessuras de sedimentos encontra-se na bacia hidrográfica do rio Capivari, nos municípios de Monte Mor, Hortolândia e Americana, onde são observadas espessuras da ordem de 300 a $400 \mathrm{~m}$ em poços tubulares profundos. Ao norte da área (próximo ao município de Engenheiro Coelho), espessuras consideráveis, da ordem de $300 \mathrm{~m}$, também são encontradas. 
Os corpos intrusivos de diabásios estão distribuídos em diversos tamanhos e às diversas profundidades. As duas maiores extensões de corpos de diabásio situam-se na parte central (Campinas) e ao norte da área (Santo Antônio da Posse).

A análise da porcentagem e da espessura de arenitos em perfis geológicos de poço tubulares profundos indicam maior concentração dessa litologia em subsuperfície dispostas em uma larga faixa, que se inicia na porção oeste da área (Santa Bárbara - d'Oeste, Americana e Nova Odessa) e finaliza nas cabeceiras da Bacia do Rio Capivari (chegando a 85\%). Secundariamente na porção centro-norte (arredores do Rio Jaguari, nos municípios de Holambra e de Cosmópolis), também há ocorrências de valores significativos da espessura e porcentagem da espessura de arenito (Figura 28 e Figura 29).

\subsubsection{Diabásios}

Os corpos de diabásios, intrusivos na porção sedimentar da área de estudos e em alguns pontos no embasamento cristalino, apresentam-se em forma de diques, sills, lacólitos ou corpos irregulares de diversos tamanhos e a várias profundidades. IG (1996), determina que em subsuperfície, os diabásios são encontrados como corpos irregulares alojados preferencialmente na interface entre o embasamento cristalino e a base dos sedimentos do Subgrupo Itararé, atingindo espessuras que podem superar 300 m. O contato dessas rochas com as encaixantes é abrupto, muitas vezes subvertical.

Os maiores corpos aflorantes situam-se em Campinas (porção central) comportando uma área de cerca de $150 \mathrm{~km}^{2}$ e em Santo Antônio da Posse (nordeste da área), com cerca de $300 \mathrm{~km}^{2}$ de extensão.

A Figura 30 (mapa de espessura de diabásio na área) demonstra a distribuição dos corpos de diabásio em subsuperfície, concentrando-se em uma área que se extende da porção central a noroeste da área (de Campinas a Americana, e proximidades). Os corpos de diabásio, de extensão limitada, estão distribuídos em direção preferencial NW e NE, concordantes com as principais direções estruturais da região, como também com a direção dos corpos de diabásio por todo o estado de São Paulo. 


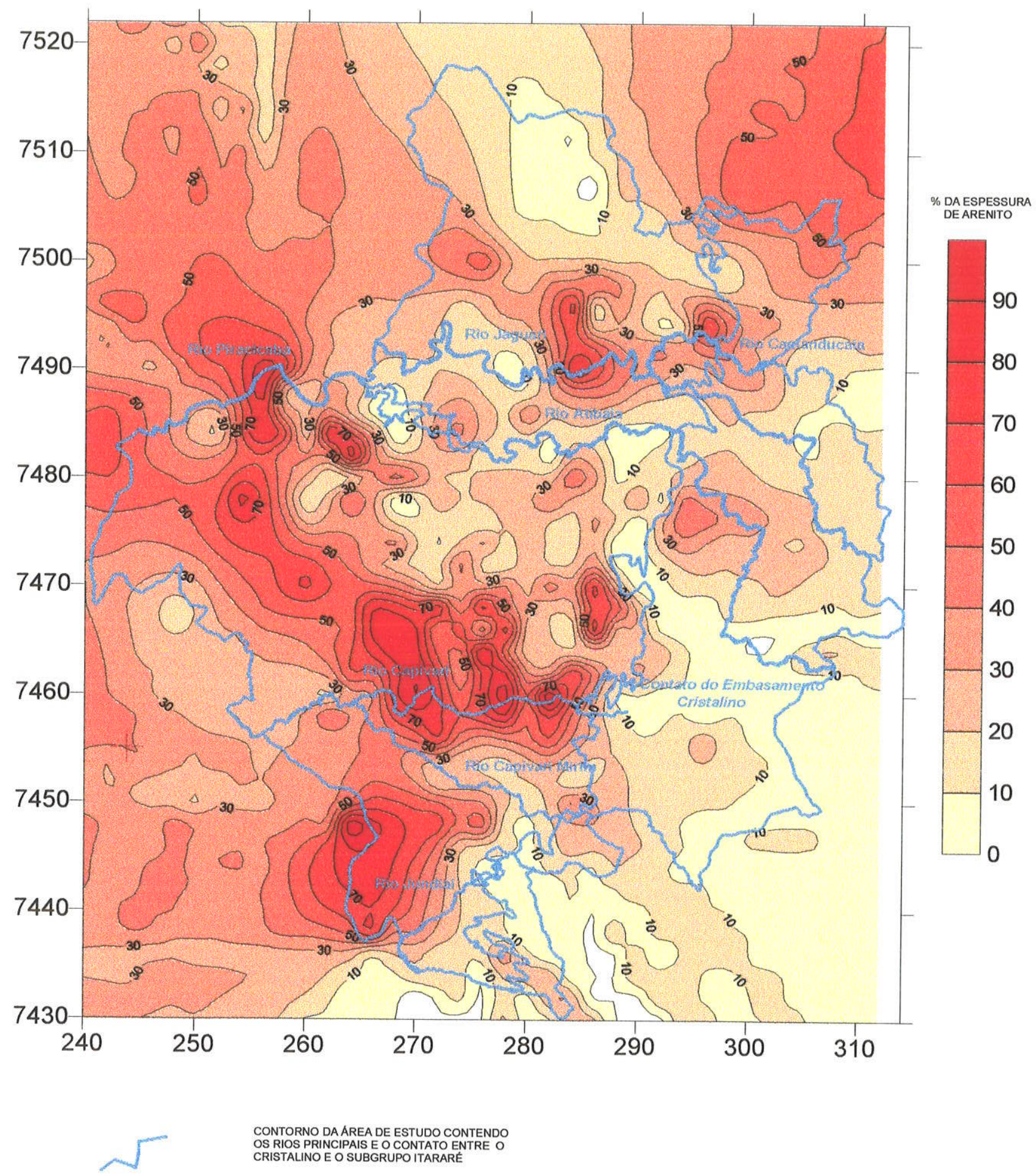

Figura 28 - Área de ocorrência de arenitos (em \%) em subsuperfície na Região Metropolitana de Campinas 


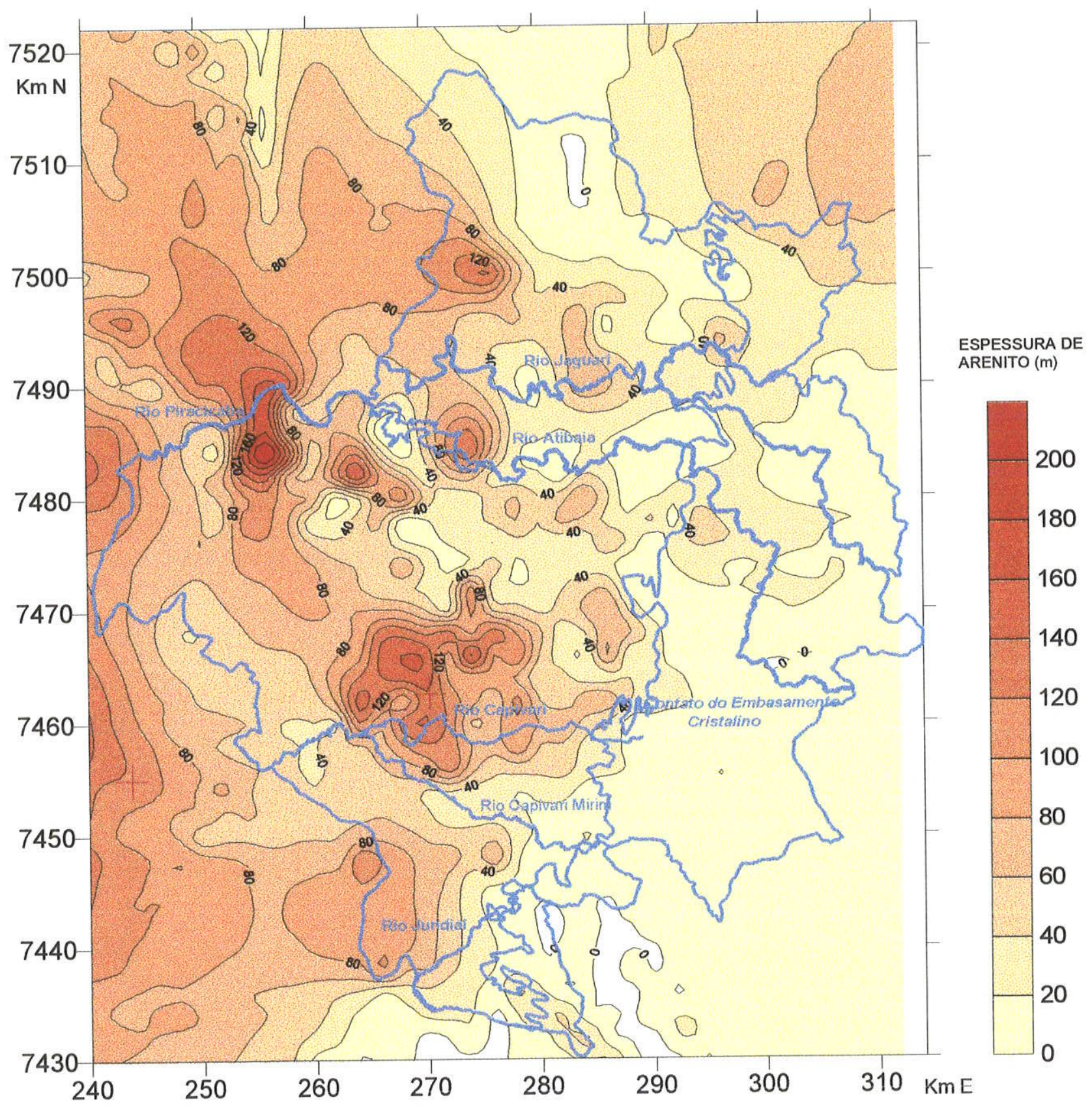

CONTORNO DA AREA DE ESTUDO CONTENDO
OS RIOS PRINCIPAIS E O CONTATO ENTRE O CRISTALINO E O SUBGRUPO ITARARE

Figura 29 - Área de ocorrência de arenitos (m) em subsuperfície na Região Metropolitana de Campinas 


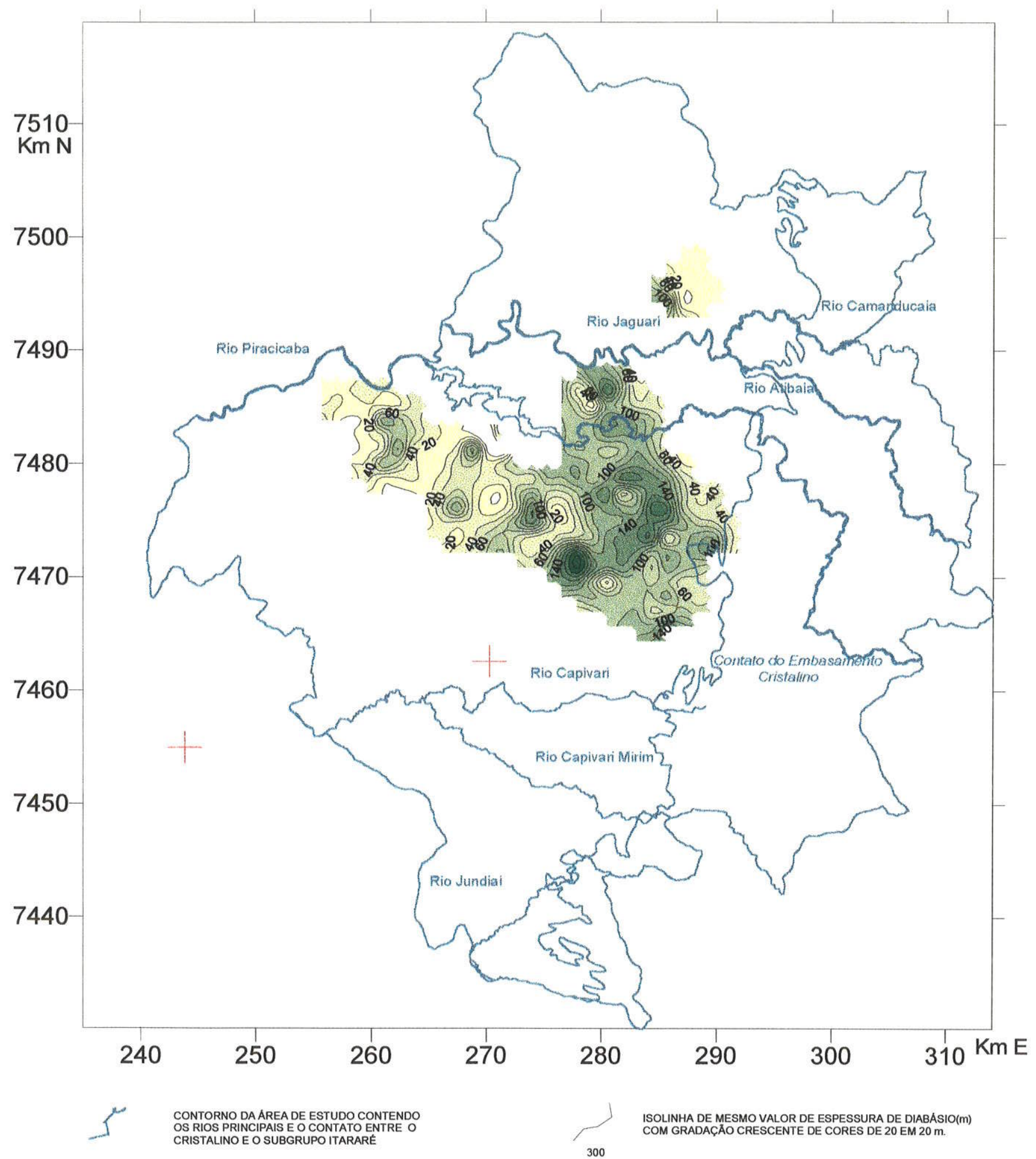

Figura 30 - Área de ocorrência de diabásios em superfície e em subsuperfície na Região Metropolitana de Campinas 


\subsubsection{Cenozóico}

Os depósitos cenozóicos apresentam-se em grandes extensões, principalmente na porção leste e norte da região metropolitana, e ao sul, em corpos menores. Esses sedimentos foram subdivididos em unidades litológicas como: coberturas arenosas, lamitos e arenitos pelíticos, siltitos/arenitos e areias com matriz argilosa - são correspondentes à Formação Rio Claro, de idade Terciária.

Esses sedimentos são pouco litificados e apresentam espessuras que podem atingir de 35 a $40 \mathrm{~m}$; ocorrem em topos de relevos suaves (colinas amplas e amplas de topos sub-horizontalizados), capeando sedimentos do Subgrupo Itararé, e subordinadamente diabásios e rochas do embasamento cristalino.

Os depósitos cenozóicos comportam aquíferos freáticos, dada sua posição estratigráfica (em áreas elevadas, correspondendo a áreas de recarga locais) e espessuras pouco expressivas, são considerados fontes de recarga dos aquíferos mais importantes como também aquíferos para captações de menor porte, como as cacimbas e as fontes.

\subsubsection{Aluviões}

Os aluviões correspondem aos sedimentos das planícies de inundação e terraços dos rios, constituídos de areias finas até grossas sedimentos silto-argilosas com lentes de areia micácea fina a muito fina, argilas e siltes.

As maiores ocorrências desses sedimentos são encontradas nos rios Jaguarí, Atibaia, Capivari e Jundiaí; apresentam-se com pouca espessura, e um nível de água subaflorante a aflorante: trata-se de zonas de descargas locais de água subterrânea. 


\subsubsection{Circulação das Águas Subterrâneas - condições de recarga e descarga locais}

As águas subterrâneas exploradas pelos poços tubulares profundos na Região Metropolitana pertencem a um sistema de fluxo de caráter local, com forte influência das variações da topografia dos terrenos.

A figura 31 demonstra a disposição das linhas equipotenciais. O embasamento cristalino, situado à leste da área, apresenta terrenos de cotas topográficas mais elevadas e conseqüentemente os maiores gradientes hidráulicos da área. Os sentidos divergentes de fluxo para as cotas mais baixas e a disposição menos espaçadas das linhas equipotenciais, observadas principalmente na porção sul da área, indicam apresença do divisor das águas subterrâneas e a área de recarga da região.

$\mathrm{Na}$ parte central e ao norte, algumas áreas de recarga locais podem ser visualizadas por meio da existência de divisores situados entre os rios Capivari e Atibaia e em terrenos situados na margem direita do rio Jaguari.

O caimento gradativo das cotas topográfica é acompanhado pelas equipotenciais, que se espaçam com a diminuição da declividade do terreno.

As áreas de descarga situam-se na porção centro-oeste e sudoeste, nos rios de maior porte como o Atibaia e o Jaguari (Represa de Salto Grande e arredores), o Capivari, o ribeirão Quilombo (afluente da margem esquerda do rio Piracicaba), e o rio Jundiaí. 


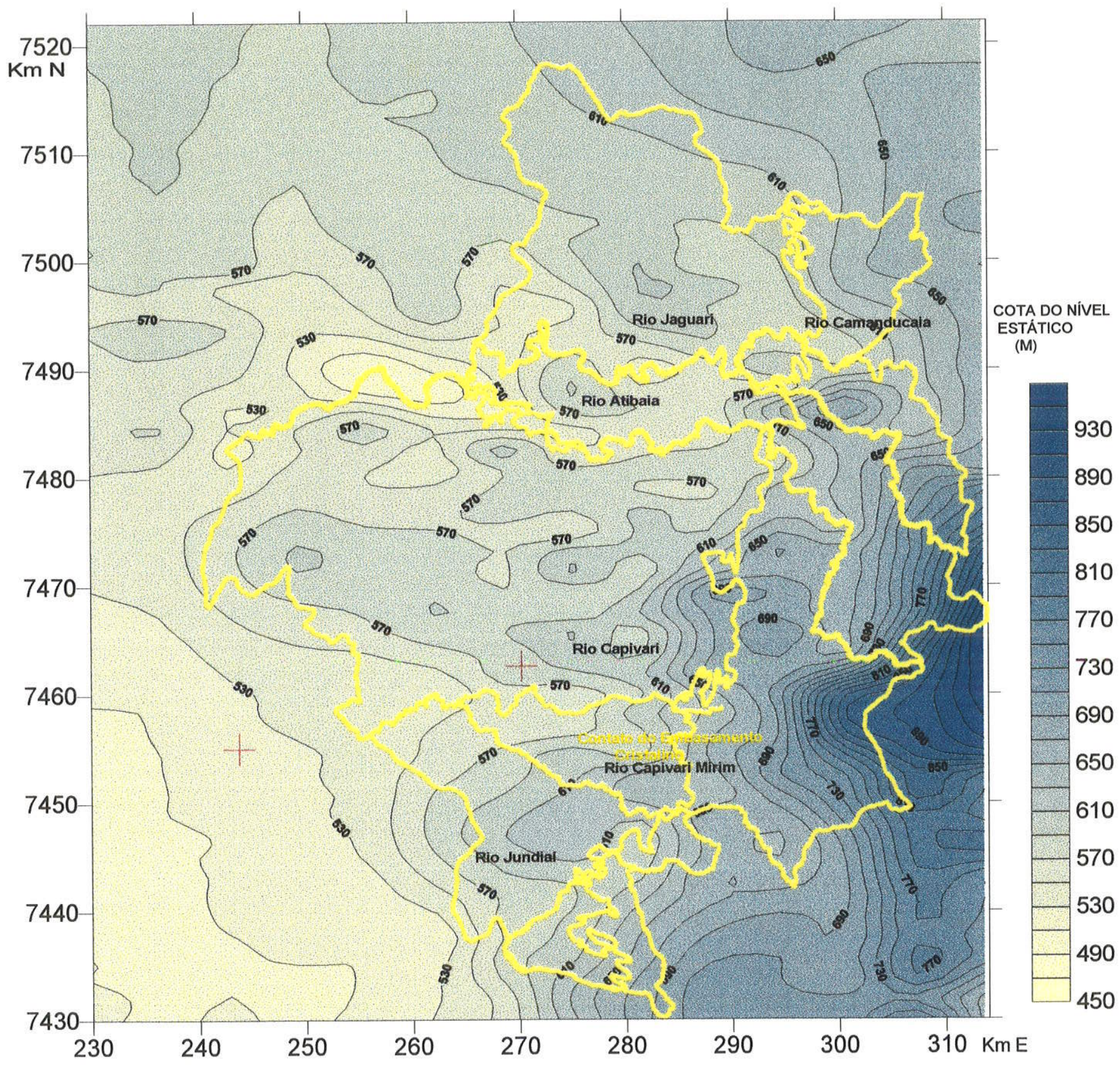

CONTORNO DA ÁREA DE ESTUDO CONTENDO

OS RIOS PRINCIPAIS E O CONTATO ENTRE O

CRISTALINO E O SUGRUPO ITARARÉ

Figura 31 - Mapa de distribuição das linhas equipotenciais na Região Metropolitana de Campinas 


\subsubsection{Caracterização Hidrodinâmica}

A Região Metropolitana de Campinas comporta dois grandes Sistemas Aqüiferos de caráter regional: o Sistema Aqüifero Cristalino, de porosidade fissural, ocorrente na parte leste da área e o Sistema Aqüífero Tubarão, especificamente o Aqüífero Itararé, de porosidade primária, aflorante na porção central e oeste.

"Secundariamente, os corpos de diabásio são considerados aqüíferos locais, devido sua ocorrência em corpos de diversas dimensões e em profundidades variadas; sua produtividade está associada aos fraturamentos da rocha.

Por fim, os sedimentos dos depósitos cenozóicos, ocorrentes em topos de relevos colinosos de grande amplitude, e os aluviões, nas margens dos rios, são os aqüíferos de porosidade primária com produtividade limitada. Em geral não são explorados pelos poços tubulares profundos da região, e portanto não avaliados nesse ítem.

$\mathrm{Na}$ caracterização hidrodinâmica, são analisados individualmente os sistemas aqüíferos Tubarão, Cristalino e o aqüífero Diabásio, como também áreas onde existem poços que exploram mais de um aqüífero.

O Sistema Aqüifero Cristalino apresenta-se na literatura como um aqüifero de extensão regional, de porosidade secundária (a circulação das águas ocorre nas fraturas das rochas), anisotrópico e heterogêneo, de comportamento semi-confinado a livre e descontínuo.

$\mathrm{Na}$ caracterização hidrodinâmica dos 312 poços que exploram somente esse aqüífero, determinou-se uma capacidade específica mediana de $0,1 \mathrm{~m}^{3} / \mathrm{h}$ por metro de rebaixamento (média de $0,28 \mathrm{~m}^{3} / \mathrm{h}$ por metro de rebaixamento) e vazão mediana de 5,2 $\mathrm{m}^{3} / \mathrm{h}$ (média de $7,3 \mathrm{~m}^{3} / \mathrm{h}$ ).

A figura 32 e a tabela 13 demonstram a distribuição da capacidade específica e da vazão, onde os valores se concentram nos intervalos de 0,05 a 0,5 (principalmente no intervalo 0,05 a 0,2$) \mathrm{m}^{3} / \mathrm{h}$ por metro de rebaixamento e 1 a $10 \mathrm{~m}^{3} / \mathrm{h}$ (relevantemente no intervalo entre 1 a $6 \mathrm{~m}^{3} / \mathrm{h}$.

Os valores de transmissividade variam de 0,13 a $6,85 \mathrm{~m}^{3} / \mathrm{dia} / \mathrm{m}$ (Tabela 14). 
Tabela 13 - Valores de mediana e média de capacidade específica e vazão de poços localizados no Sistema Aqüífero Cristalino

\begin{tabular}{|lrrrrr|}
\hline \multicolumn{5}{|c}{ POÇOS LOCALIZADOS NO SISTEMA AQÜÍFERO CRISTALINO } \\
& MÉDIA & MEDIANA & MODA & MIN & MAX \\
Q & 7,31 & 5,2 & 6 & 0 & 55 \\
CAESP & 0,2766 & 0,1 & 0 & 0 & 8 \\
\hline
\end{tabular}

CAESP - $\mathrm{m} 3 / \mathrm{h}$ por metro de rebaixamento (capacidade especifica)

$\mathrm{Q}-\mathrm{m} 3 / \mathrm{h}$ (vazăo)

Figura 32 - Distribuição da capacidade específica e da vazão em poços localizados no Sistema Aqüífero Cristalino
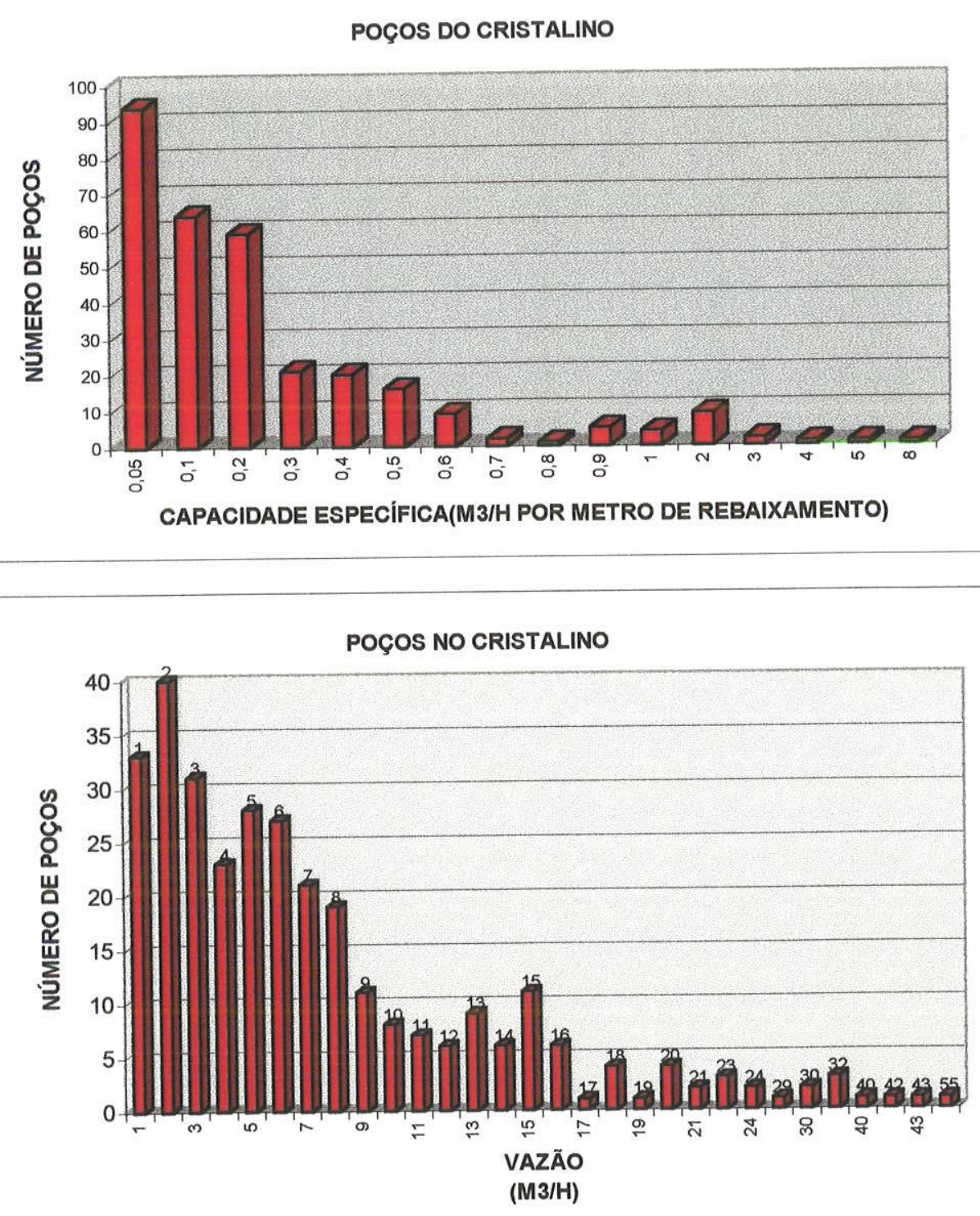
Tabela 14 - Valores de transmissividades calculadas em poços do Sistema Aqüífero Cristalino

\begin{tabular}{|l|c|c|}
\hline 1 - & \\
\hline 102 - MACSOL S/A & 3,13 & 0,32 \\
\hline 091 - MACSOL S/A & 6,10 & 0,13 \\
\hline 090 - GBC LTDA & 2,20 & 0,14 \\
\hline 106 - PROMON S/A & 1,09 & 0,18 \\
\hline 107 - ABC XTAL MICROEL & 12,18 & 6,85 \\
\hline 109 - SOC. SAGR. COR. JESUS & 4,47 & 0,29 \\
\hline 435 - SANASA & 2,4 & 1,18 \\
\hline
\end{tabular}

Os maiores valores medianos da capacidade específica dos poços e as vazões localizam-se dentro de lineamentos de drenagem, indicando a íntima relação entre a produtividade e a presença de estruturas das rochas hospedeiras. A tabela 15 e 16 e as figuras 33 e 34 apresentam a distribuição dos valores da capacidade específica e das vazões de poços locados em lineamentos de drenagem e fora deles, e a grande diferença entre os valores determinados de capacidade específica.

O Sistema Aqüífero Tubarão - Aqüifero Itararé possui grande complexidade hidrogeológica, haja visto o ambiente deposicional extremamente complexo de seus sedimentos, e consequentemente as ocorrências de fácies interdigitadas de difícil entendimento espacial e estratigráfico. Esse sistema é considerado como aqüifero de extensão regional, de porosidade granular, livre a semi-confinado, heterogêneo, descontínuo e anisotrópico.

$\mathrm{Na}$ área de estudo, os poços localizados nesse sistema aqüífero apresentam valores medianos de capacidade específica e vazão de $0,11 \mathrm{~m}^{3} / \mathrm{h}$ por metro de rebaixamento e $6,0 \mathrm{~m}^{3} / \mathrm{h}$, respectivamente. A distribuição da capacidade específica e vazão por número de poços estão representadas na figura 35 e tabela 17. 
Tabela 15 - Valores de mediana e média de capacidade específica e vazão localizados em lineamentos de drenagem no Sistema Aqüífero Tubarão

\begin{tabular}{|lrrrrrr|}
\hline \multicolumn{4}{r}{ POÇOS DO CRISTALINO LOCALIZADOS EM LINEAMENTOS DE DRENAGEM } \\
& MEDIA & MEDIANA & MODA & MIN & \multicolumn{2}{c|}{ MAX } \\
Q & 9,78 & 4,81 & 6 & 0,00 & 55,00 \\
CAESP & 0,4236 & 0,1438 & 0 & 0,00 & 4,5077 \\
\hline
\end{tabular}

CAESP - $\mathrm{m} 3 / \mathrm{h}$ por metro de rebaixamento (capacidade especifica)

Q - m3/h (vazão)

Figura 33 - Distribuição da capacidade específica e vazão em poços localizados em lineamentos de drenagem no Sistema Aqüífero Cristalino

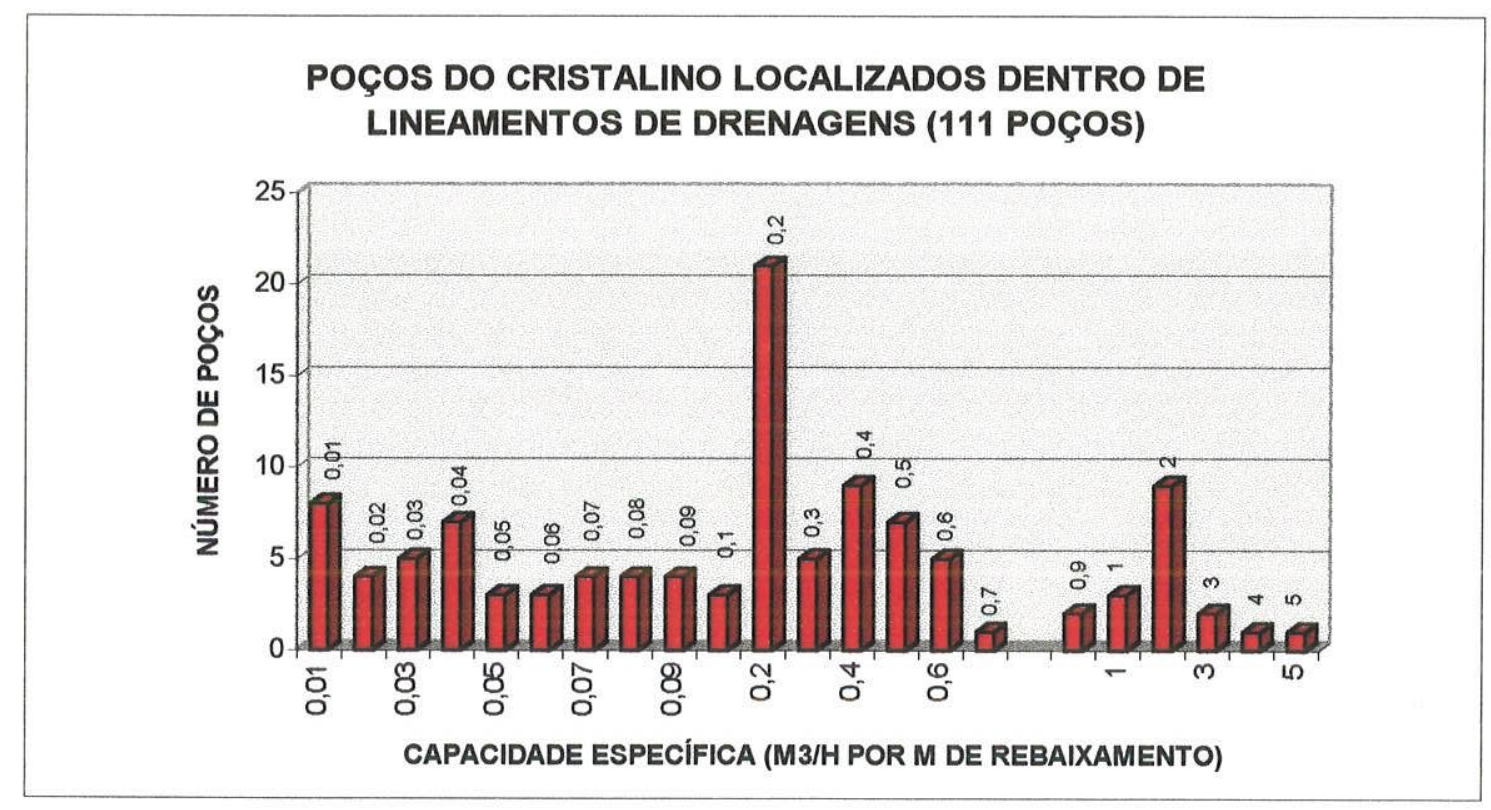

\section{POÇOS DO CRISTALINO LOCALIZADOS EM LINEAMENTOS DE DRENAGENS (111 POÇOS)}

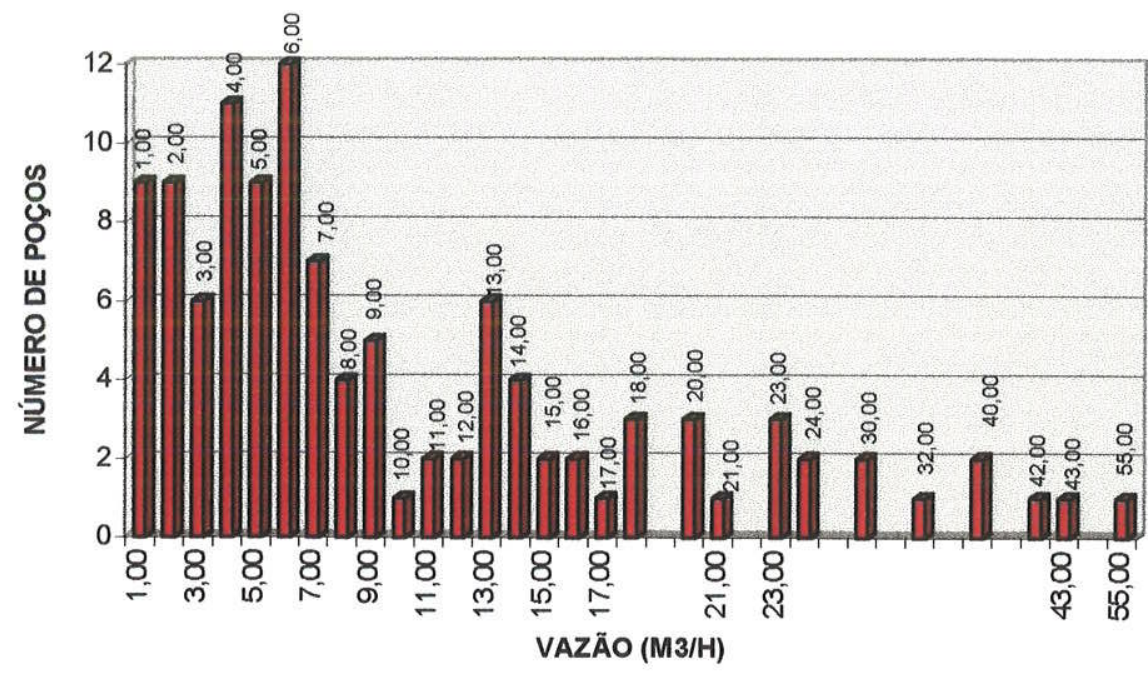


Tabela 16 - Valores de mediana e média de capacidade específica e vazão de poços localizados fora de lineamentos de drenagem no Sistema Aqüifero Cristalino

\begin{tabular}{|crccrrr|}
\hline \multicolumn{1}{|c|}{ POÇOS DO CRISTALINO LOCALIZADOS FORA DOS LINEAMENTOS DE DRENAGENS } \\
& MEDIA & MEDIANA MODA & \multicolumn{3}{c|}{ MIN } & \multicolumn{2}{c|}{ MAX } \\
Q & 5,95 & 4,70 & 6 & 0,00 & 32,00 \\
CAESP & 0,1957 & 0,0917 & 0 & 0,0000 & 8,0000 \\
\hline
\end{tabular}

Figura 34 - Distribuição da capacidade específica e da vazão em poços localizados fora de lineamentos de drenagens no Sistema Aqüifero Cristalino
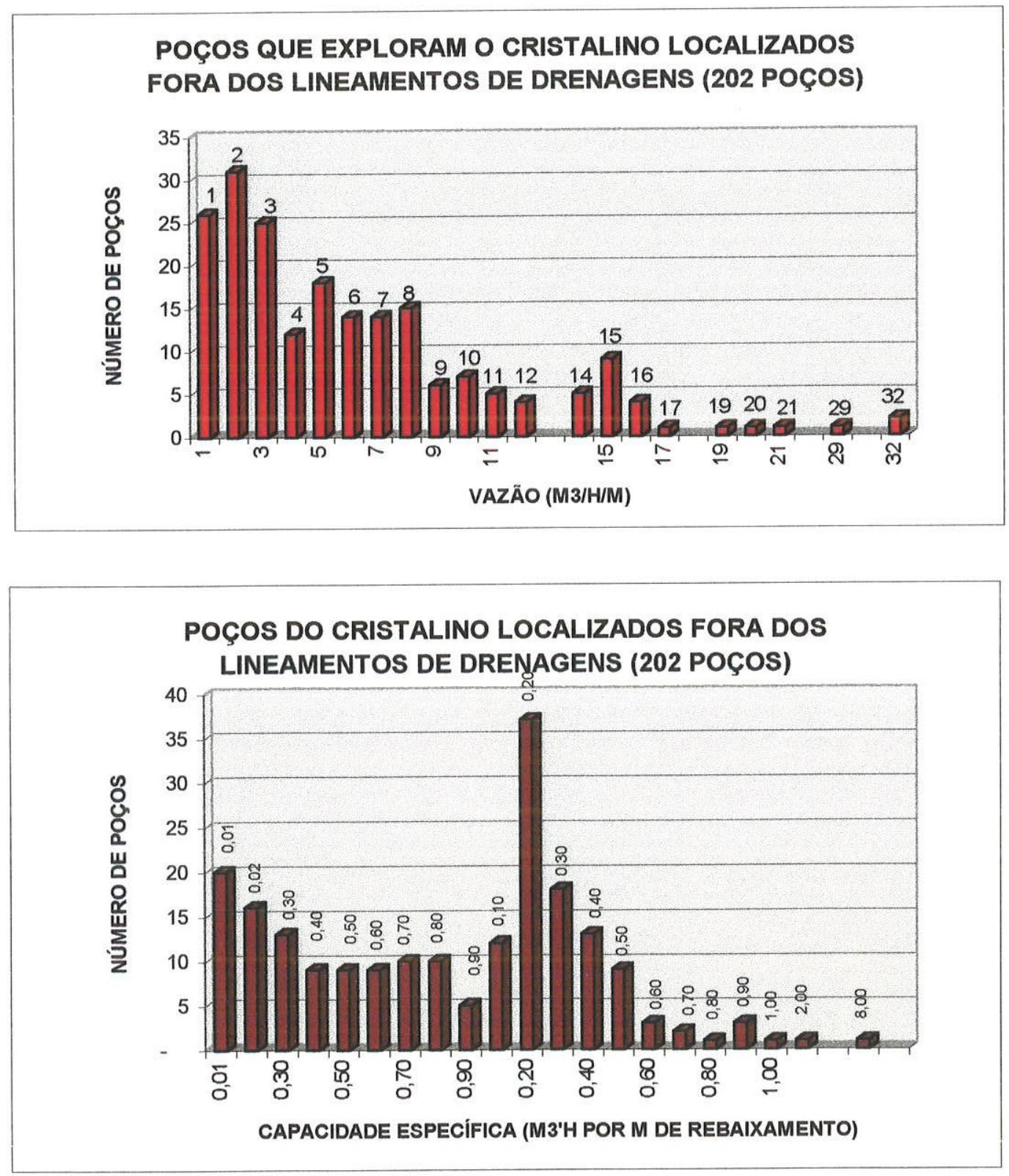
Tabela 17 - Valores de mediana e média de capacidade específica e vazão de poços localizados no Sistema Aqüífero Tubarão - Aquífero Itararé

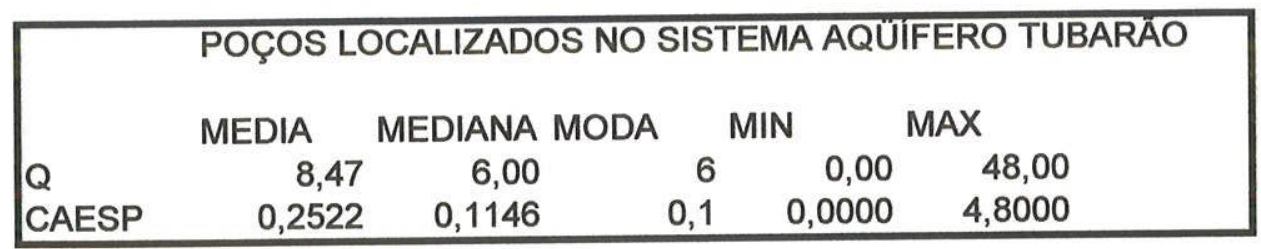

Figura 35 - Distribuição da capacidade específica e da vazão de poços no Sistema Aqüifero Tubarão - Aqüifero ltararé

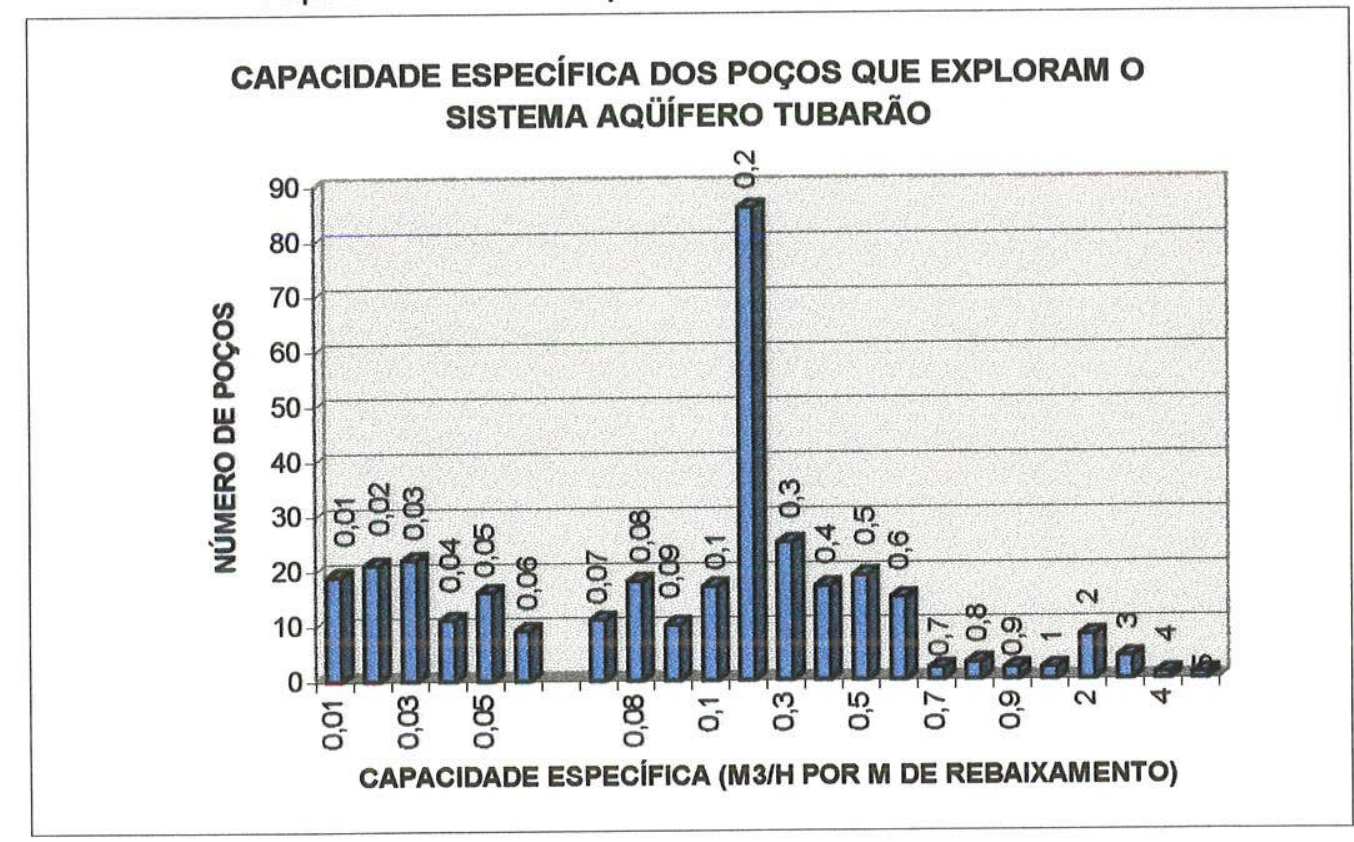

VAZÃO DE POÇOS QUE EXPLORAM O SISTEMA AQÜÍFERO TUBARÃO

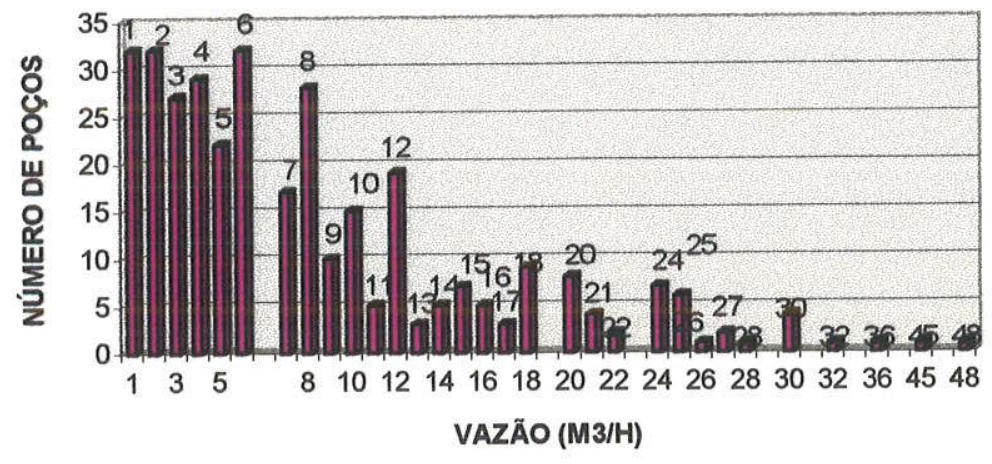


É interessante destacar a presença marcante de poços com valores no intervalo 0,1 e $0,2 \mathrm{~m}^{3} / \mathrm{h}$ por metro de rebaixamento e das vazões, entre os intervalos de 1 a 12 $\mathrm{m}^{3} / \mathrm{h}$, que podem ser considerados como limitações quanto à produtividade desse sistema aqüífero.

A influência das estruturas das rochas na produtividade dos poços desse sistema também é importante. Nas figuras 36 e 37 e tabelas 18 e 19, apresentam-se os valores medianos de capacidade específica e vazão obtidos em poços localizados em lineamentos de drenagens $\left(0,14 \mathrm{~m}^{3} / \mathrm{h}\right.$ por metro de rebaixamento e $12 \mathrm{~m}^{3} / \mathrm{h}$, respectivamente) contra $0,125 \mathrm{~m}^{3 / h}$ por metro de rebaixamento e $7,0 \mathrm{~m}^{3} / \mathrm{h}$ de valores medianos desses parâmetros obtidos em poços situados fora dos lineamentos de - drenagem.

A análise dos perfis geológicos de poços tubulares profundos determinou espessuras de arenito e porcentagem da espessura de arenito, que foram correlacionadas à produtividade dos poços. Há uma tendência do aumento dos valores de produtividade em função da presença de arenito em maiores porcentagens (Figura 38 e Tabela 20).

O Aqüifero Diabásio apresenta os mais baixos valores medianos de capacidade especifica e vazão $\left(0,06 \mathrm{~m}^{3} / \mathrm{h}\right.$ por metro de rebaixamento e $\left.4,5 \mathrm{~m}^{3} / \mathrm{h}\right)$ encontrados na região metropolitana. A distribuição dos valores de capacidade específica e vazão indicam maiores concentrações nos intervalos mais baixos $\left(0\right.$ a $0,01 \mathrm{~m}^{3} / \mathrm{h}$ por metro de rebaixamento e entre 0 a $1 \mathrm{~m}^{3} / \mathrm{h}$, respectivamente) (Figura 39 e Tabela 21).

A produtividade desse aqüifero está condicionada aos fraturamentos existentes na rocha, corroborada com a determinação de uma capacidade específica mediana de 0,12 $\mathrm{m}^{3} / \mathrm{h}$ por metro de rebaixamento em poços locados dentro de lineamentos de drenagens, em detrimento do valor conseguido de $0,05 \mathrm{~m}^{3} / \mathrm{h}$ por metro de rebaixamento, mediana dos valores determinados em poços situados fora dos lineamentos desses (Figuras $40 \mathrm{e}$ 41 , Tabelas 22 e 23).

A grande quantidade de poços que exploram mais de um sistema aqüifero (cerca de 271 poços tubulares profundos) justificou uma análise distinta da hidrodinâmica e produtividade na área de estudo. 
Tabela 18 - Valores de mediana e média de capacidade específica e vazão de poços localizados em lineamentos de drenagem no Sistema Aqüífero Tubarão Aqüífero Itararé

\begin{tabular}{|c|c|c|c|c|c|c|}
\hline \multirow[b]{3}{*}{$Q$} & \multicolumn{6}{|c|}{$\begin{array}{l}\text { POÇOS DO SISTEMA AQÜÍFERO TUBARÃO - AQÜÍFERO ITARARÉ } \\
\text { LOCALIZADOS DENTRO DE LINEAMENTOS DE DRENAGEM }\end{array}$} \\
\hline & MÉDIA & MEDIANA & MODA & MIN & & \\
\hline & 12,9 & 12 & & 12 & 0,5 & 48 \\
\hline CAESP & 0,3977 & 0,1429 & & 0,1 & 0,0083 & 2,6667 \\
\hline
\end{tabular}

Figura 36 - Distribuição da capacidade específica e da vazão em poços localizados em lineamentos de drenagem no Sistema Aqüífero Tubarão - Aqüifero Itararé
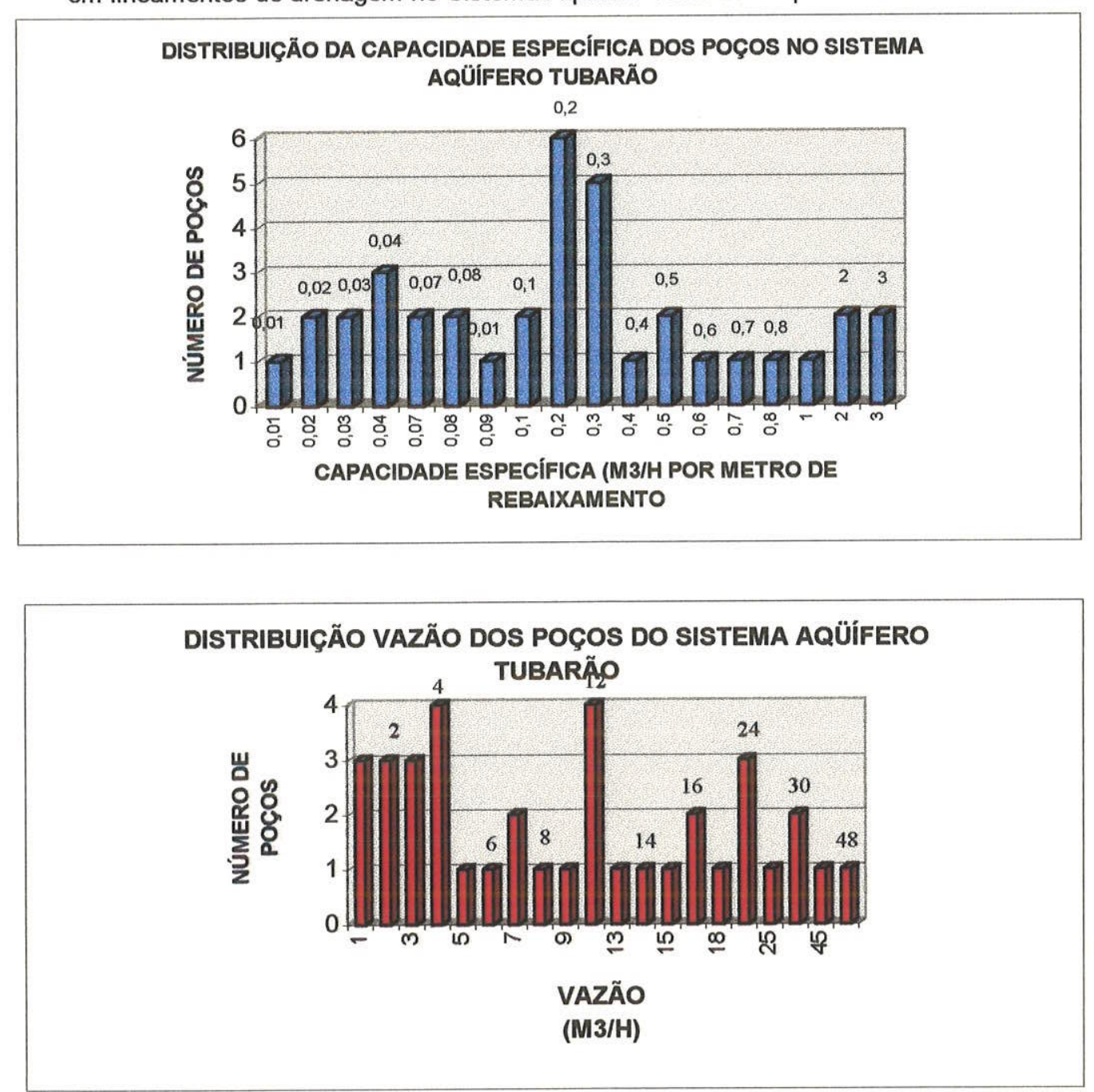
Tabela 19 - Valores de mediana e média de capacidade específica e vazão de poços localizados fora de lineamentos de drenagem no Sistema Aqüifero Tubarão Aqüífero Itararé

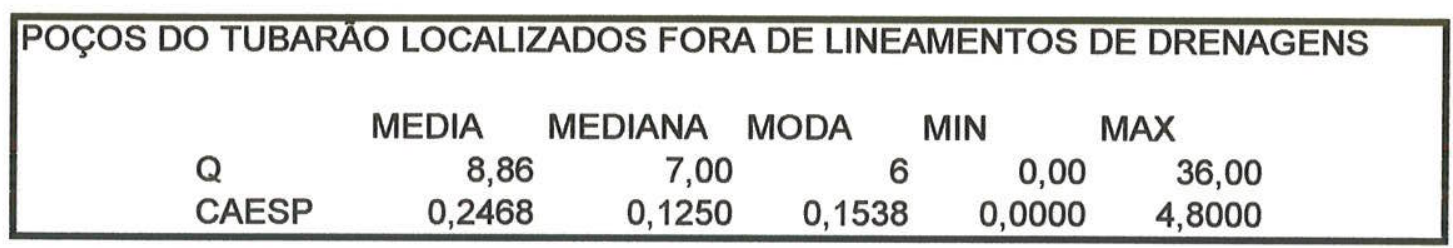

Figura 37 - Distribuição da capacidade específica e da vazão em poços localizados fora de lineamentos de drenagem no Sistema Aqüifero Tubarão - Aqüifero Itararé

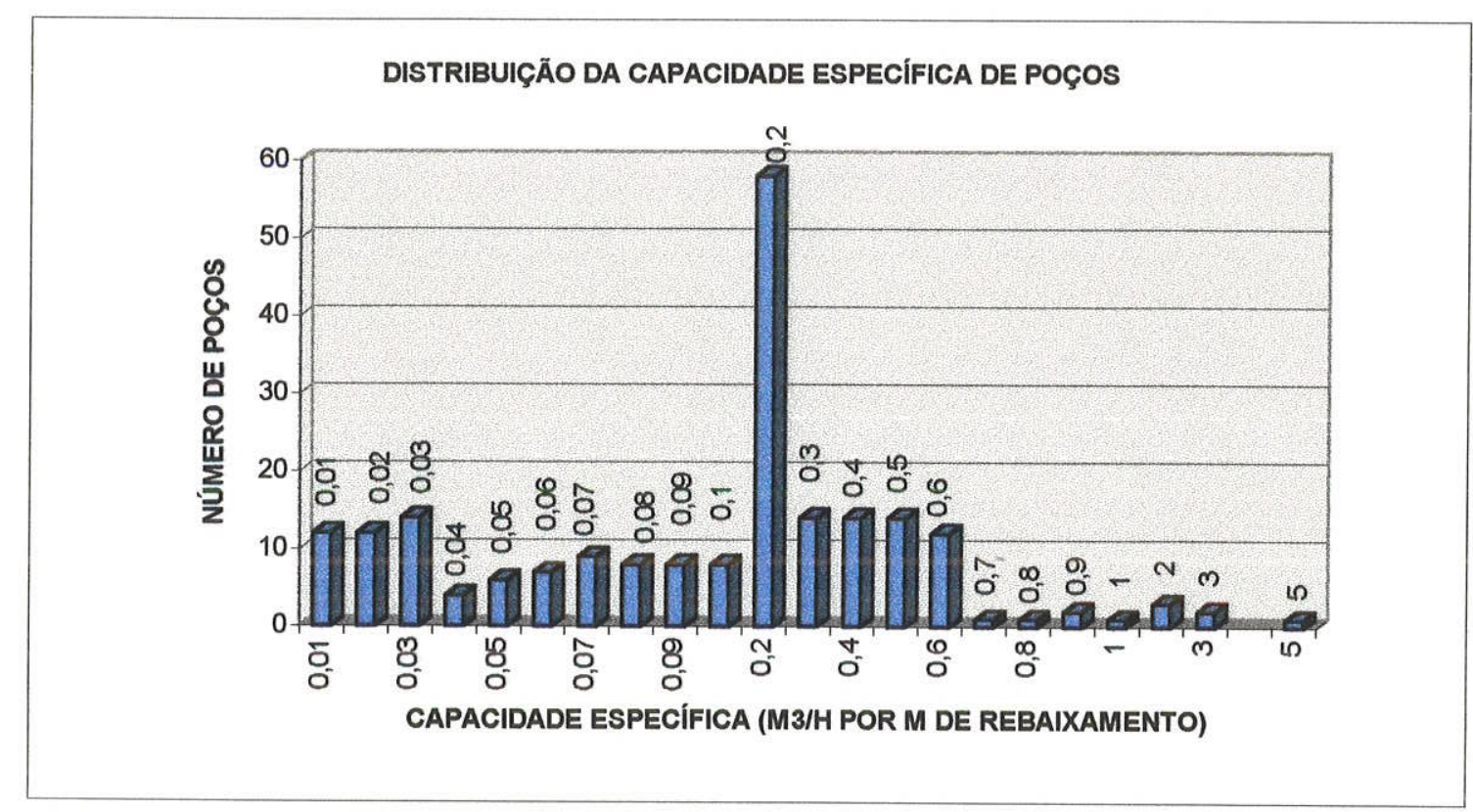

\section{DISTRIBUIÇÃO DA VAZÃO DOS POÇOS}

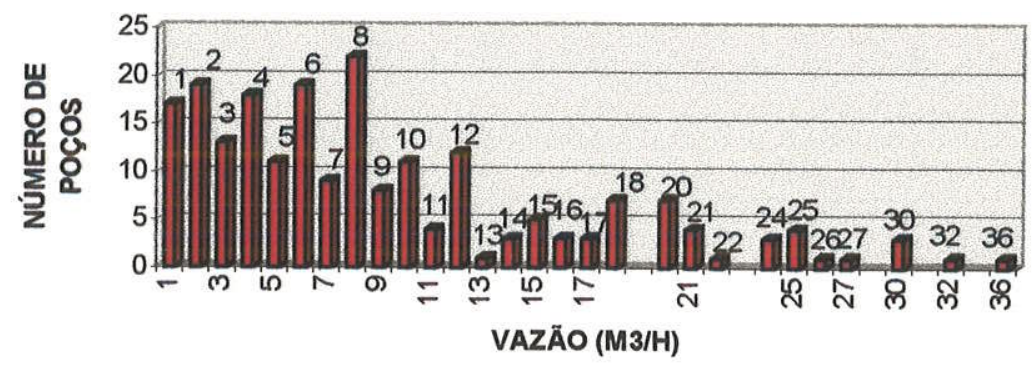


Tabela 20 - Valores de mediana e média de espessuras de arenito em relação a capacidade específica no Sistema Aqüifero Tubarão - Aqüífero Itararé

\begin{tabular}{|ccccccr|}
\hline \multicolumn{7}{|c|}{ POÇOS DO TUBARAO - ARENITO X CAPACIDADE ESPECIFICA (CAESP) } \\
\hline \multirow{2}{*}{ CAESP } & MEDIA & \multicolumn{2}{c|}{ ESPESSURA DE ARENITO (\%) } & \multicolumn{3}{c|}{ MIN } \\
& 0,1 & 38 & 33 & 26 & 100 & 0 \\
0,2 & 56 & 63 & 100 & 100 & 3 \\
0,3 & 52 & 55 & \#N/A & 94 & 10 \\
0,4 & 47 & 50 & 19 & 92 & 5 \\
0,5 & 60 & 72 & 75 & 100 & 12 \\
0,6 & 49 & 53 & 25 & 91 & 0 \\
1 & 47 & 32 & \#N/A & 81 & 12 \\
2 & 54 & 46 & \#N/A & 90 & 17 \\
$>2$ & 54 & 53 & \#N/A & 86 & 25 \\
\hline
\end{tabular}

Figura 38 - Distribuição da capacidade específica em função da maior porcentagem da espessura de arenito no Sistema Aqüífero Tubarão - Aqüífero Itararé

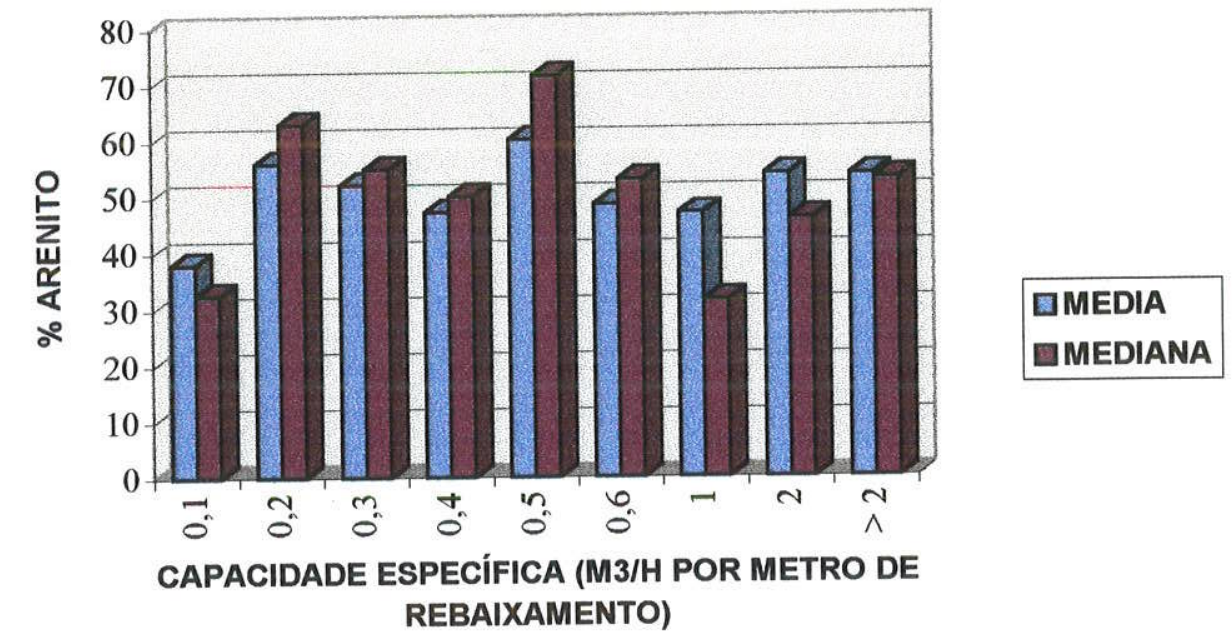


Tabela 21 - Valores de mediana e média de capacidade específica e vazão de poços que exploram o Diabásio

\begin{tabular}{|lrrrrr|}
\hline \multicolumn{5}{|c|}{ POÇOS QUE EXPLORAM O DIABÁSIO } \\
MÉDIA & MEDIANA & MODA & MAX & \multicolumn{1}{c|}{ MIN } \\
CAESP & 0,7865 & 0,0600 & 0 & 16,6000 & 0,0000 \\
Q & 6,30 & 4,50 & 0 & 35,66 & 0,00 \\
PROF & 141,83 & 135,00 & 150 & 300,00 & 50,00 \\
\hline
\end{tabular}

Figura 39 - Distribuição da capacidade específica e vazão dos poços localizados em diabásios
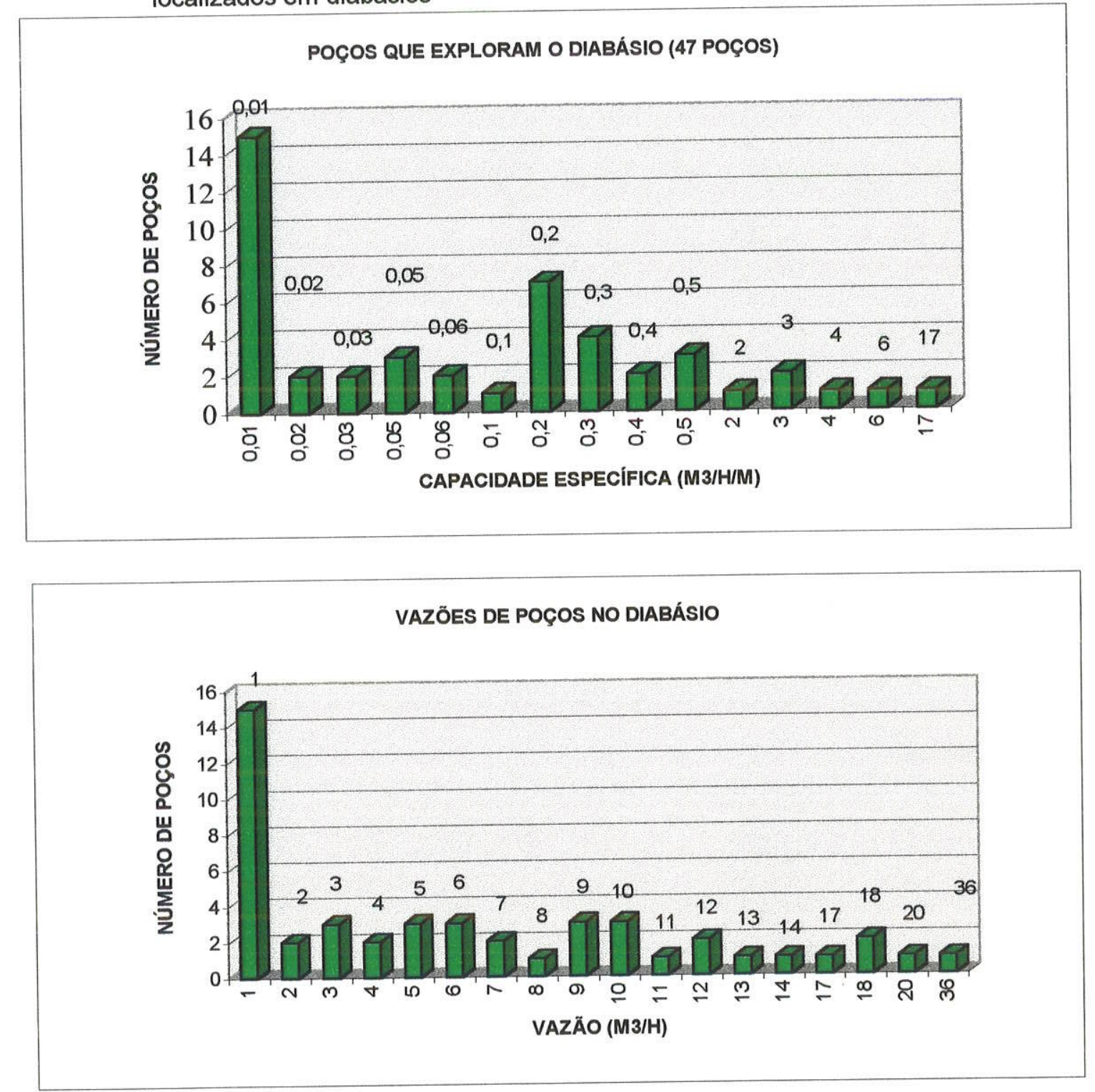
Tabela 22 - Valores de mediana e média de capacidade específica e vazão de poços que exploram o diabásio localizados em lineamentos de drenagem

\begin{tabular}{|lrrrrr|}
\hline \multicolumn{5}{c|}{ POÇOS DO DIABÁSIO DENTRO DE LINEAMENTOS } \\
\cline { 3 - 6 } & MÉDIA & MEDIANA & MODA & MAX & \multicolumn{1}{c|}{ MIN } \\
CAESP & 1,9894 & 0,1190 & 0 & 16,6000 & 0,0000 \\
$Q$ & 7,73 & 5,75 & 0 & 20,00 & 0,00 \\
\hline
\end{tabular}

CAESP - M3/H/M (capacidade específica)

$Q-M 3 / H$ (vazão)

Figura 40 - Distribuição da capacidade específica de poços localizados em lineamentos de drenagem em diabásios

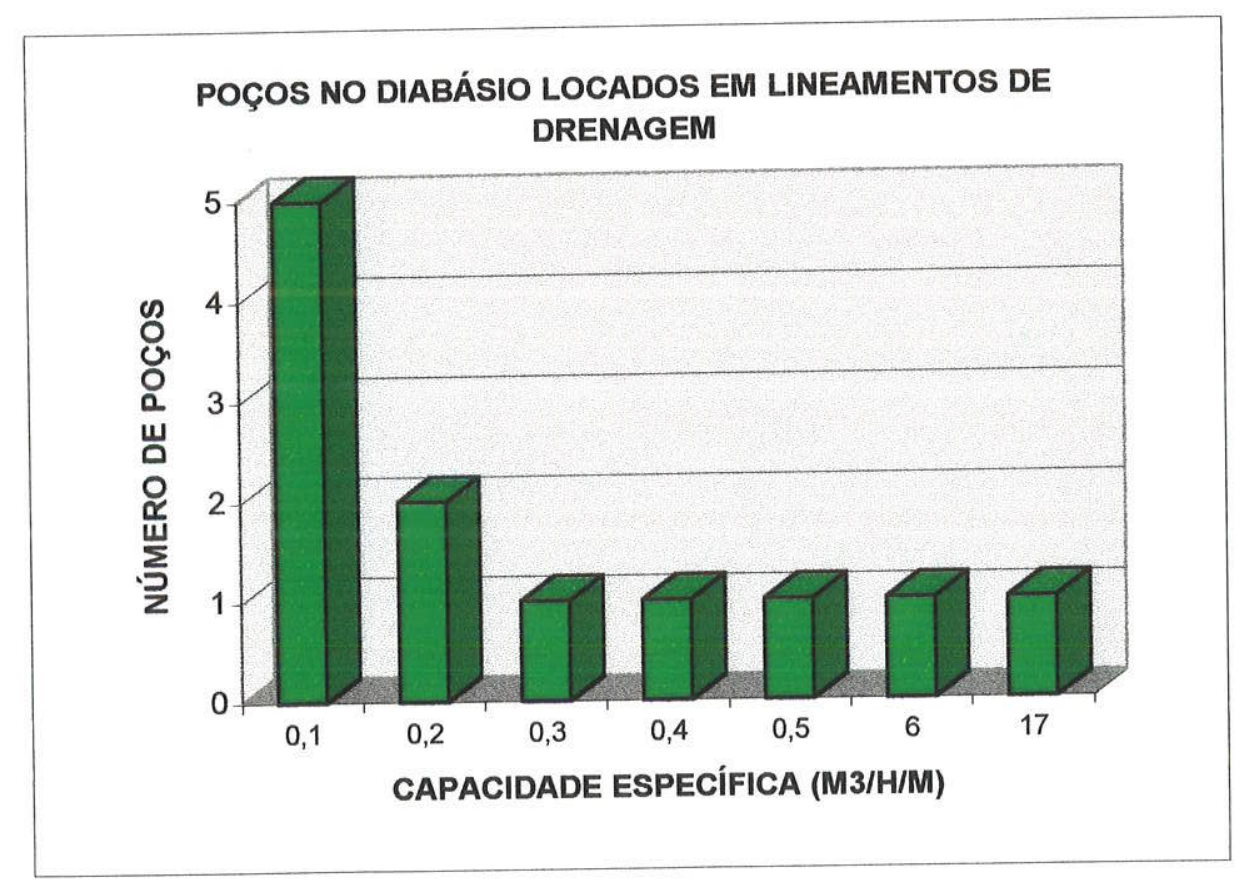


Tabela 23 - Valores de mediana e média de capacidade específica e dos poços que exploram o diabásio localizados fora de lineamentos de drenagem

\begin{tabular}{|lrcrrr|}
\hline \multicolumn{5}{|c|}{ POÇOS LOCADOS NO DIABÁSIO FORA DE LINEAMENTOS } \\
\multicolumn{4}{c}{ DE DRENAGENS } \\
CAESP & 0,3741 & 0,0491 & 0 & 3,9622 & 0,0000 \\
Q & 5,81 & 4,50 & 0 & 35,66 & 0,00 \\
\hline
\end{tabular}

CAESP - $m 3 / h$ por metro de rebaixamento (capacidade específica)

$Q-m 3 / h$ (vazão)

Figura 41 - Distribuição da capacidade específica em poços localizados fora de lineamentos de drenagem nos diabásios

\section{POÇOS NO DIABÁSIO LOCADOS FORA DOS LINEAMENTOS DE DRENAGENS}

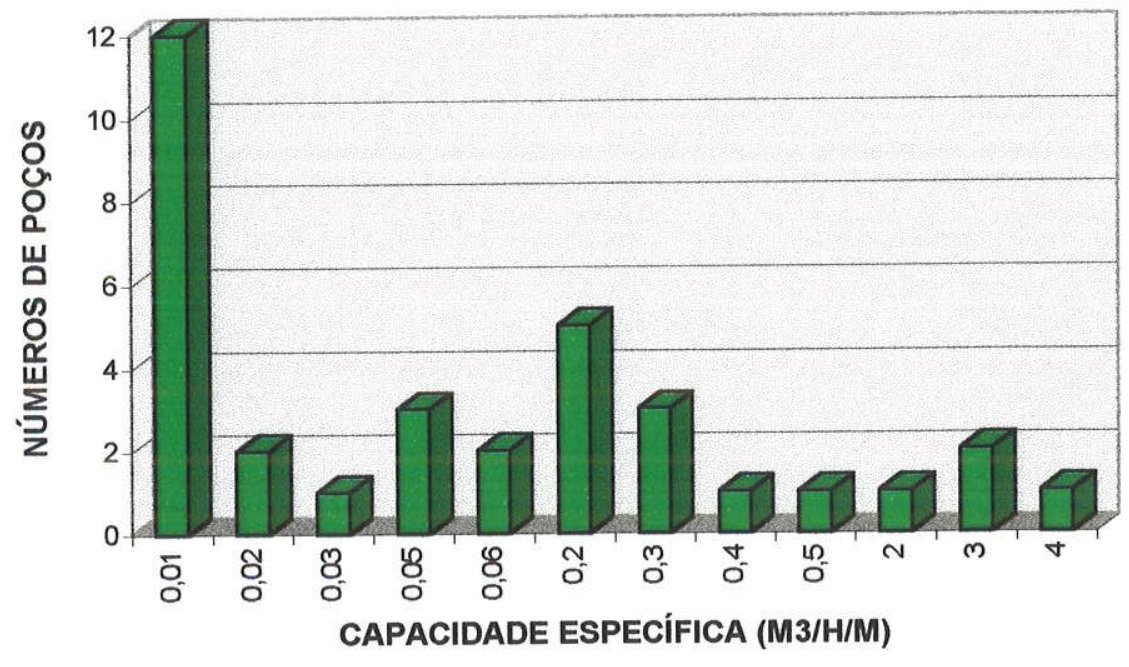


Essa situação é decorrente da situação geológica da área: trata-se da borda da Bacia Sedimentar do Paraná, cujos sedimentos são ainda pouco espessos e por isso as rochas do embasamento cristalino são encontradas a baixas profundidades. Além disso, há as ocorrências de diabásio em superfície e subsuperfície, em corpos de extensão limitada, que aumenta ainda mais a complexidade dessa região de borda de bacia.

Em geral, a capacidade específica mediana obtida para essa área foi de $0,07 \mathrm{~m}^{3} / \mathrm{h}$ por metro de rebaixamento (mediana de vazão de $4,8 \mathrm{~m}^{3} / \mathrm{h}$ ). Na distribuição dos valores de capacidade específica por número de poços tubulares profundos, nota-se uma concentração de valores nos intervalos de 0,05 a $0,3 \mathrm{~m}^{3} / \mathrm{h}$ por metro de rebaixamento, onde cerca de 108 valores de capacidade específica dos poços encontram-se nesse primeiro intervalo $\left(0,05 \mathrm{~m}^{3} / \mathrm{h}\right.$ por metro de rebaixamento) (Figura 42 e Tabela 24).

A influência dos fraturamentos, existentes nessa área na produtividade dos poços tubulares profundos não é notada em um primeiro momento, com a obtenção de valores medianos similares de capacidade específica e vazão para poços situados dentro e fora de lineamentos de drenagem (em torno de $0,07 \mathrm{~m}^{3} / \mathrm{h}$ por metro de rebaixamento e 4,5 $\mathrm{m}^{3 /} \mathrm{h}$, respectivamente) (Figuras 43 e 44, e Tabelas 25 e 26).

Os poços tubulares que exploram os Sistemas Aqüíferos Tubarão e Diabásio apresentaram melhores produtividades, conseguindo valores medianos de capacidade específica $\left(0,1 \mathrm{~m}^{3} / \mathrm{h}\right.$ por metro de rebaixamento) em detrimento dos poços que exploram os sistemas Cristalino, Tubarão e Diabásio e os sistemas Tubarão e Cristalino (Tabela 27).

A transmissividade foi calculada para três poços mistos que exploram os sistemas Tubarão e Cristalino, obtendo-se valores de 0,113, 2,77 e 0,71 m²/dia/m (Tabela 28). 
Tabela 24: Valores de mediana e média de capacidade específica de poços que exploram mais de um aqüifero

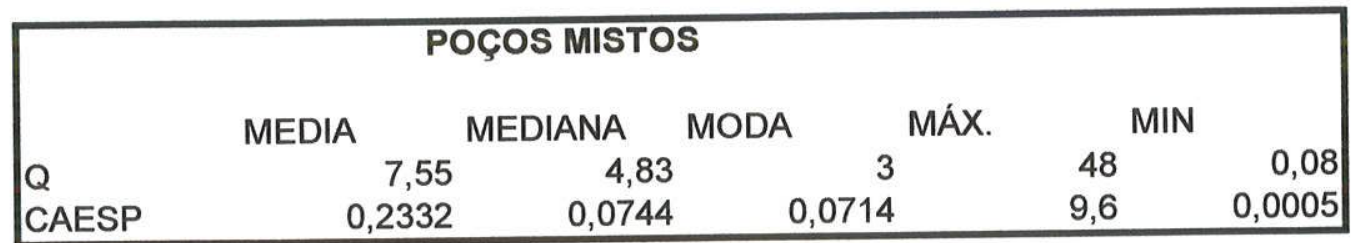

CAESP - $\mathrm{m} 3 / \mathrm{h}$ por metro de rebaixamento (capacidade especifica)

$Q-m 3 / h$ (vazăo)

Figura 42 - Distribuição da capacidade específica de poços que exploram mais de um aqüífero (poços mistos)

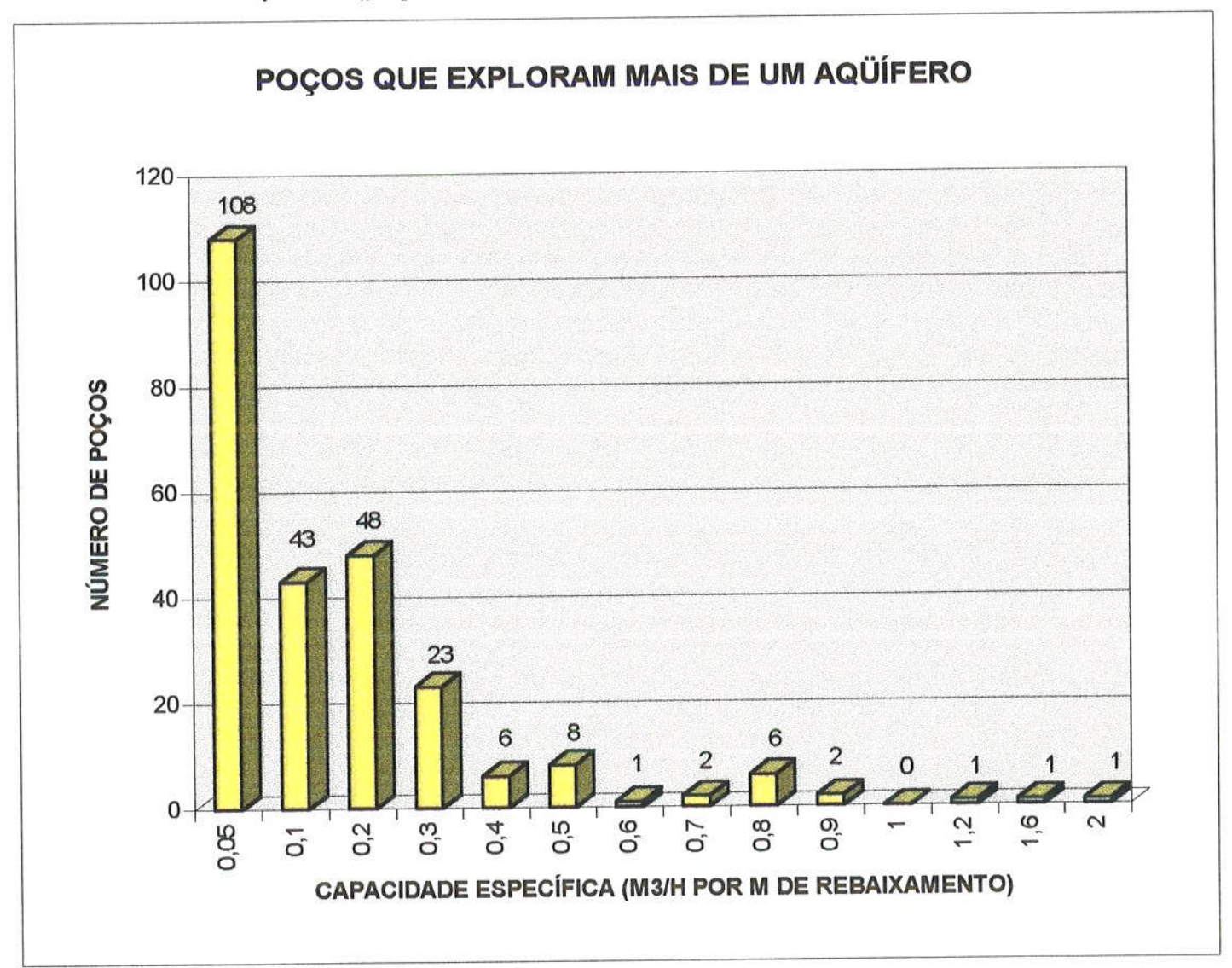


Tabela 25 - Valores de mediana e média de capacidade específica e vazão de poços que exploram mais de um aqüifero localizados em lineamentos de drenagem

\begin{tabular}{|lrrrrrr|}
\hline \multicolumn{7}{|c|}{ POÇOS MISTOS LOCALIZADOS EM } \\
LINEAMENTOS DE DRENAGENS & \\
Q & MEDIA & MEDIANA & MODA & MAX & MIN \\
CAESP & 7,05 & 5,00 & 3 & 30,00 & 0,00 \\
\hline
\end{tabular}

Figura 43 - Distribuição da capacidade específica e da vazão em poços mistos localizados em lineamentos de drenagens

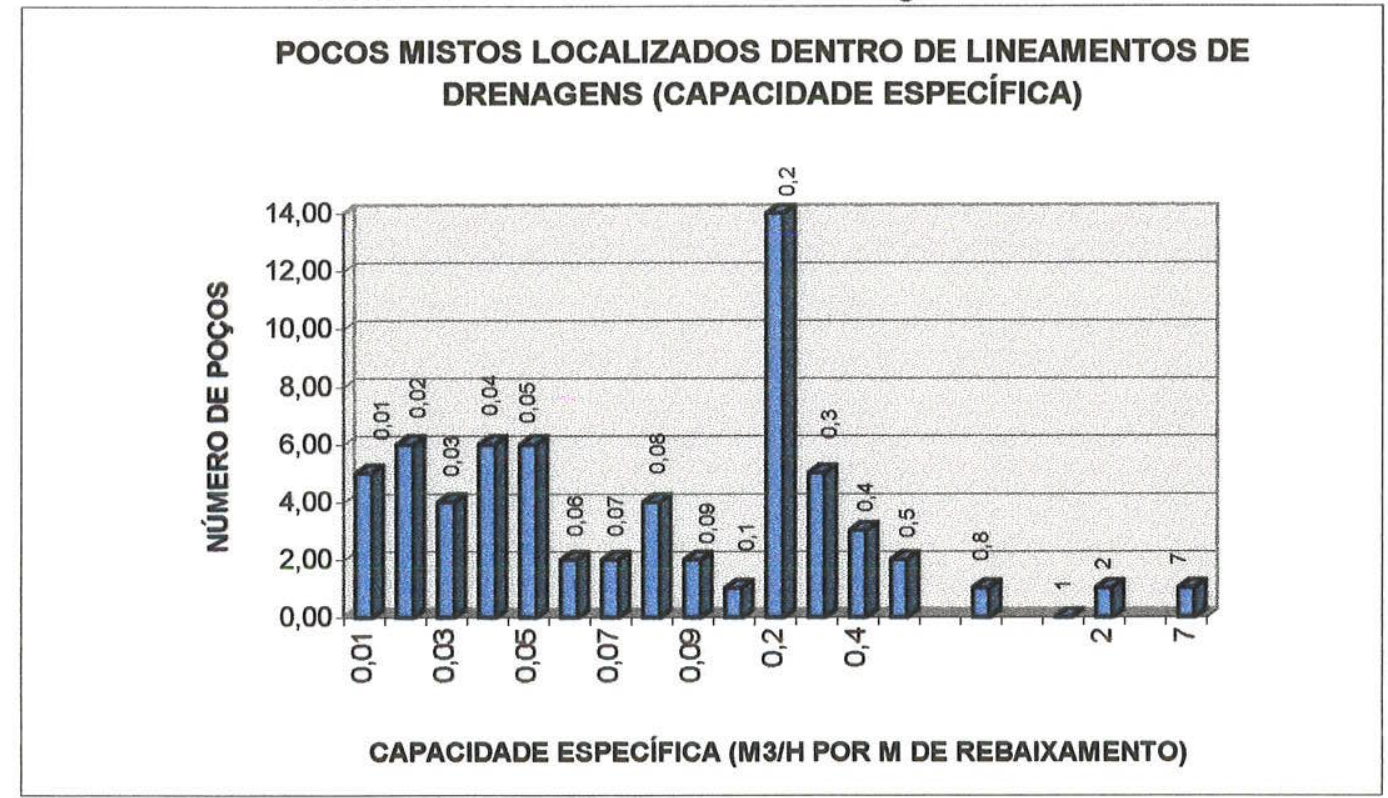

\section{POÇOS MISTOS LOCALIZADOS DENTRO DE LINEAMENTOS DE DRENAGENS (VAZÃO)}

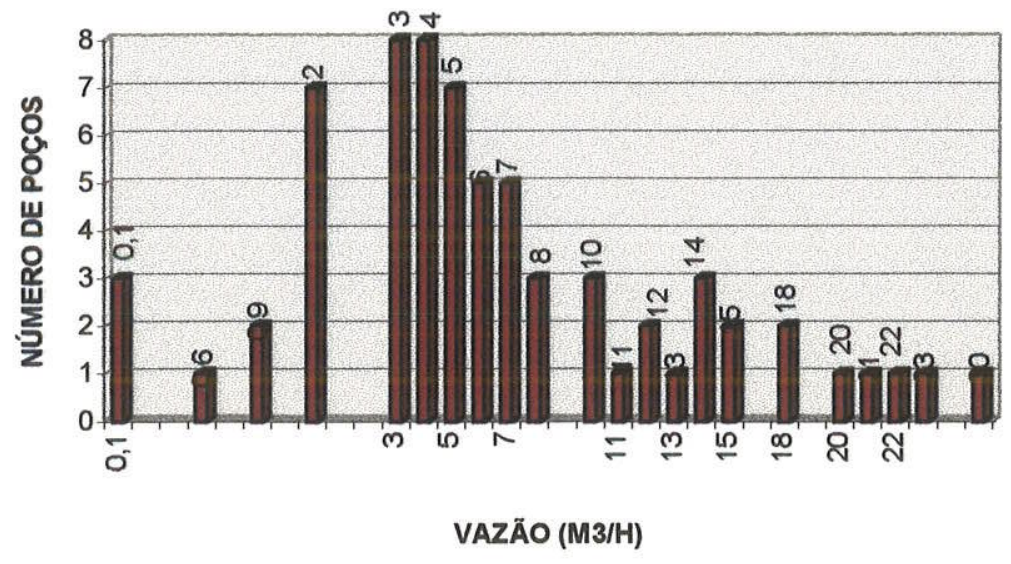


Tabela 26 - Valores de mediana e média de capacidade específica e vazão de poços que exploram mais de um aquïferos localizados fora de lineamentos de drenagem

\begin{tabular}{|lrrr|}
\hline \multicolumn{4}{|c|}{ POÇOS MISTOS FORA DE LINEAMENTO DE DRENAGEM } \\
(202 POÇOS) \\
\hline \multicolumn{4}{c}{} \\
M & MEDIA & MEDIANA MODA \\
CAESP & 7,50 & 4,30 & 3 \\
\hline
\end{tabular}

Figura 44 - Distribuição da capacidade específica e da vazão em poços mistos localizados fora de lineamentos de drenagem

DISTRIBUIÇÃO DA CAPACIDADE ESPECÍFICA DE POÇOS MISTOS

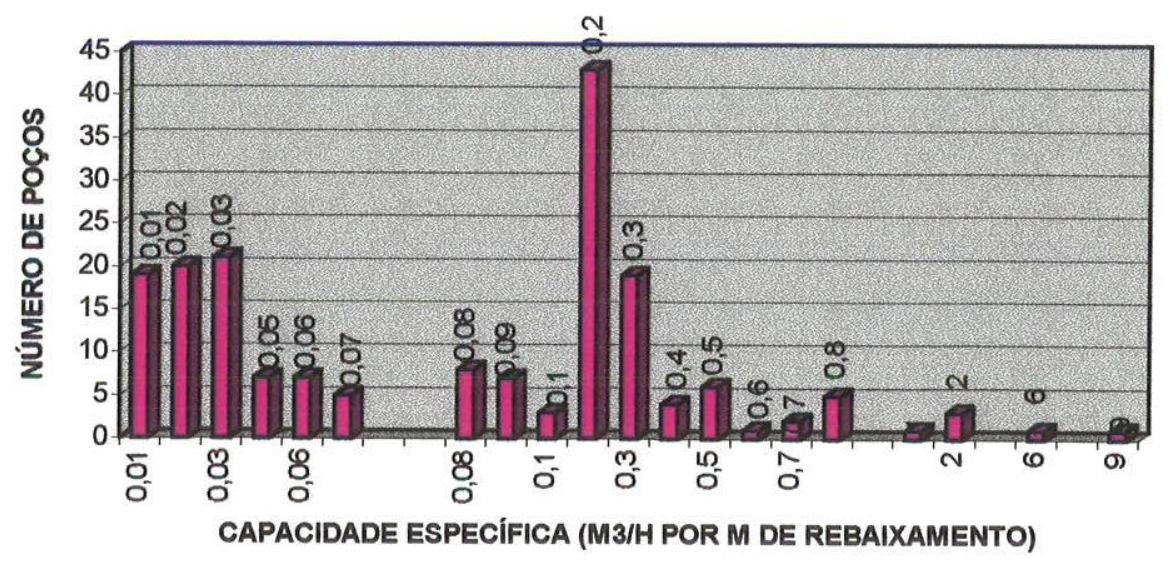

DISTRIBUIÇÃO DA VAZÃO DE POÇOS MISTOS

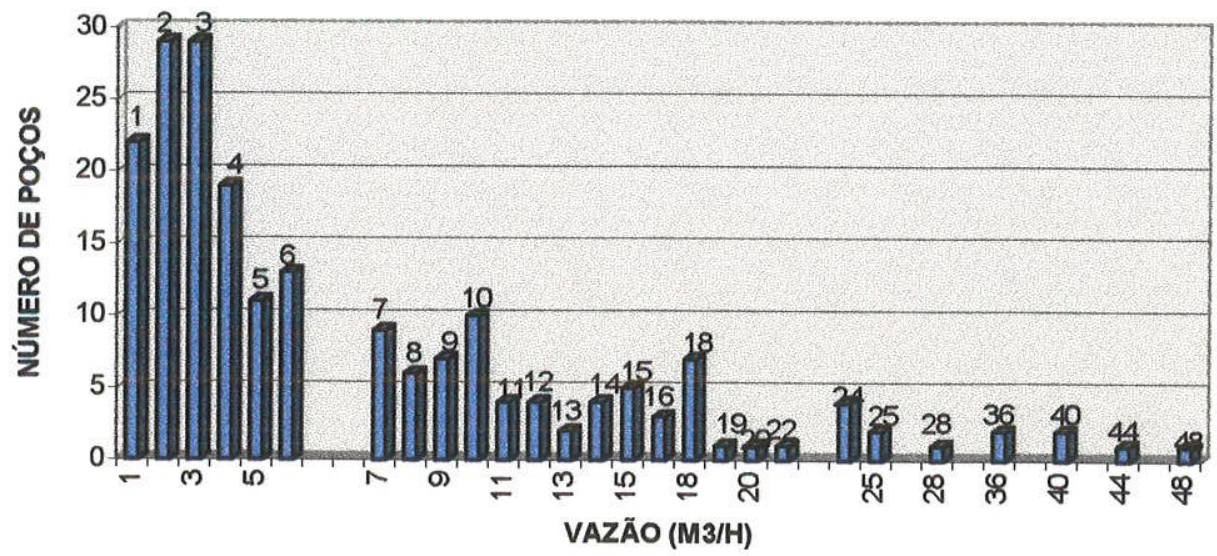


Tabela 27 - Valores de mediana e média de capacidade específica e vazão de poços mistos por tipo de sistema aqüífero explorado

\begin{tabular}{|c|c|c|c|}
\hline \multicolumn{4}{|c|}{ TUBARÁO E DIABÁSIO (TD) } \\
\hline $\begin{array}{l}\text { Q } \\
\text { CAESP }\end{array}$ & $\begin{array}{r}\text { MEDIA } \\
8,57 \\
0,2208\end{array}$ & $\begin{array}{r}\text { MEDIANA } \\
5,5 \\
0,102\end{array}$ & $\begin{array}{r}\text { MODA } \\
10 \\
0,0108\end{array}$ \\
\hline \multicolumn{4}{|c|}{ TUBARAO, CRISTALINO E DIABASIO (TDC) } \\
\hline $\begin{array}{l}\text { Q } \\
\text { CAESP }\end{array}$ & $\begin{array}{r}\text { MEDIA } \\
10,58 \\
0,5903\end{array}$ & $\begin{array}{r}\text { MEDIANA } \\
5,64 \\
0,0726\end{array}$ & $\begin{array}{r}\text { MODA } \\
\text { N/A }\end{array}$ \\
\hline \multicolumn{4}{|c|}{ TUBARÁO E CRISTALINO (TC) } \\
\hline $\begin{array}{l}\text { Q } \\
\text { CAESP }\end{array}$ & $\begin{array}{r}\text { MEDIA } \\
6,12 \\
0,1793\end{array}$ & $\begin{array}{r}\text { MEDIANA } \\
3,4 \\
0,0695\end{array}$ & $\begin{array}{r}\text { MODA } \\
3 \\
0,0714\end{array}$ \\
\hline
\end{tabular}

CAESP - $\mathrm{m} 3 / \mathrm{h}$ por metro de rebaixamento

$Q-m 3 / h$ (vazăo) 
Tabela 28 - Valores de transmissividades calculadas em poços do Sistema Aqüifero Cristalino

\begin{tabular}{|c|c|c|}
\hline Pogonlocar. & Tazio (mili) & TRANSUMISSIVIBA DE (M' TDIAMM) \\
\hline 113/ TECIDOS FIAMA & 6,6 & 2,77 \\
\hline 330/ PIRELLI PNEUS & $\overline{2,4}$ & 1,2 \\
\hline 604/PEDRALIX & 5,0 & 0,71 \\
\hline
\end{tabular}

A distribuição espacial dos valores de capacidade especifica revelou tendências de comportamento bem distintas na área de estudo.

No Sistema Aqüifero Cristalino, a produtividade dos poços tubulares profundos está relacionada aos diversos tipos de estruturas existentes nesses terrenos, definidos pelos grandes lineamentos de drenagens de direção NE e EW, predominantemente e pelo mapa geológico.

A análise dos valores de capacidade específica foi executada por meio de compartimentações baseadas nas grandes estruturações existentes e pelo modelos de blocos estruturais propostos por Pires Neto (1996).

A Figura 45 apresenta as compartimentações definidas pelas produtividades similares e estruturas.

O Bloco Lindóia-Valinhos (na parte leste de Campinas e Pedreira) não foi considerado para análise, pela inexistência de informações. Os terrenos são topograficamente elevadas e acidentadas e de baixa ocupação humana.

$\mathrm{Na}$ área de ocorrência das rochas do Complexo Itapira de composição granítica (Ciy), observa-se boas produtividades nos poucos poços existentes (de intervalo de 0,35 a $8,5 \mathrm{~m}^{3} / \mathrm{h}$ por metro de rebaixamento). A região localizada entre os rios Atibaia e Jaguari apresenta-se bastante fraturada, haja visto a ocorrência de fortes estruturações de direções NW e NNE, visualizada pela alta densidade de drenagem local. As rochas aflorantes nesse local pertencem ao Granito Morungaba, de caráter homogêneo, e as rochas granitóides do Complexo Itapira. 


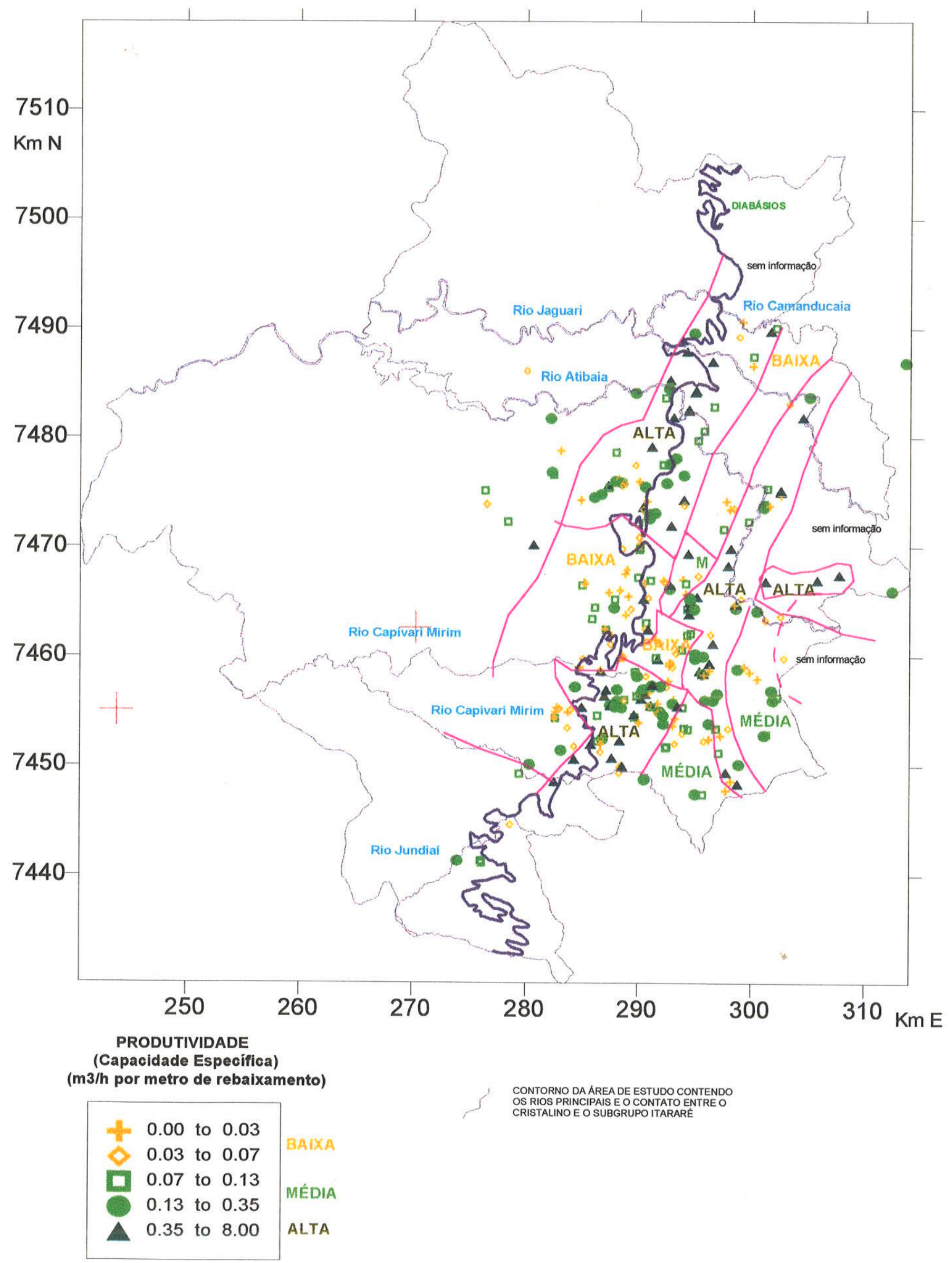

Figura 45 - Distribuição espacial da produtividade no Sistema Aqüifero Cristalino 
Essas características estruturais e litológicas sugerem um bom potencial de produtividade de poços, pois indicam grande número de juntas e fraturas por onde a água circula.

Ao sul da área descrita anteriormente, no Bloco Jundiaí, as rochas gnáissicas do Complexo Itapira são predominantes; há ocorrências na porção leste do Granito Morungaba, caracterizadas por relevos de topografia elevada e escarpadas.

"Já as rochas gnássicas comportam relevos menos acidentados, como os morros e morrotes e colinas e morrotes, e uma menor densidade de drenagem. As estruturações observadas possuem direção NW e algumas com forte inflexão para NE, seguindo a Zona de Cisalhamento Valinhos.

No cômputo geral, o potencial produtivo é considerado mediano, onde a produtividade dos poços estão relacionadas com os lineamentos de padrões NW e NNW. A primeira direção seria condicionante das drenagens principais e a segunda direção, resultante das movimentações de deslocamento (os falhamentos normais).

A exceção é feita nas proximidades do lineamento que separa o Bloco LindóiaValinhos do Jundiaí, que mais ao leste vem a constituir no Lineamento do Interflúvio Jundiaí-Atibaia (Pires Neto 1996).

Os poços localizados nessa área possuem bons valores de capacidade específica (situados nos intervalos entre 0,13 a 0,35 e 0,35 a $8 \mathrm{~m}^{3} / \mathrm{h}$ por metro de rebaixamento).

No Bloco Campinas, apesar do pequeno número de poços tubulares com valores de capacidade específica, verifica-se três tendências de produtividade: os altos valores, situados ao longo da Zona de Cisalhamento de Valinhos e na porção sul, e os valores intermediários e baixos, situados entre a Zona de Cisalhamento Campinas e a região de altos valores.

No Bloco Itu, ao sul do Bloco Campinas, os poços tubulares apresentam bom potencial produtivo, com tendência a um decréscimo desse potencial na porção limítrofe à Zonas de Cisalhamento Valinhos. As principais estruturas possuem direção EW e NE; a tendência de melhor produtividade parece situar-se ao longo dos fraturamentos de direção EW.

O Bloco Jaguariúna situa-se entre a Zona de Cisalhamento Campinas e o Lineamento Porto Feliz-Jacutinga, no contato do embasamento cristalino e em parte da 
bacia sedimentar. Ao longo da zona de cisalhamento são observados poços com boa produtividade. Nas áreas restantes, essa produção é relacionada com fortes estruturações de direção $\mathrm{EW}$, condicionantes dos rios de maior porte na região, como os rios Jaguari, Atibaia e o Camanducaia.

Nos terrenos próximos ao limite desse bloco estrutural com o Bloco Capivari, e nessa própria compartimentação, visualizam-se baixos valores de produtividade. $\mathrm{Na}$ área entre os rios Capivari e Capivari-Mirim, são encontrados altos valores de capacidade especifica.

De um modo geral, as melhores produtividades do Sistema Aqüífero Cristalino encontram-se ao longo do contato do embasamento cristalino com a bacia sedimentar, bem como a existência de tendências de bons potenciais de produção em lineamentos de drenagem de direção EW e NE (Figura 45).

A produtividade dos poços parece acompanhar também o caimento ocasionado pela movimentação dos blocos estruturais. Desse modo, no Bloco Jaguariúna uma tendência de boa produtividade aparece a noroeste do bloco, que possui um caimento suave na mesma direção.

No Bloco Itu, as maiores produtividades se encontram na porção noroeste, concordantes com a direção do caimento desse bloco estrutural; o mesmo é ocorrente no Bloco Jundiaí, com adernamento recente para noroeste.

O Sistema Aqüífero Tubarão - Aqüífero Itararé apresenta uma distribuição mais caótica dos valores de capacidade específica, coerente com a complexidade faciológica de sedimentos de ambiente de plataforma e avanços e recuos de geleiras. No entanto, existem tendências de distribuição dos valores desse parâmetro.

As áreas de menores produtividades situam-se ao longo do contato do aqǘfero sedimentar com o cristalino (parte de Campinas e Indaiatuba) e na porção central da região metropolitana (abrangendo os municípios de Paulínia, Sumaré, Nova Odessa, Artur Nogueira e Jaguariúna) (Figura 46).

Os valores intermediários são encontrados na parte norte da área, envolvendo os municípios de Holambra e Santo Antonio da Posse. 


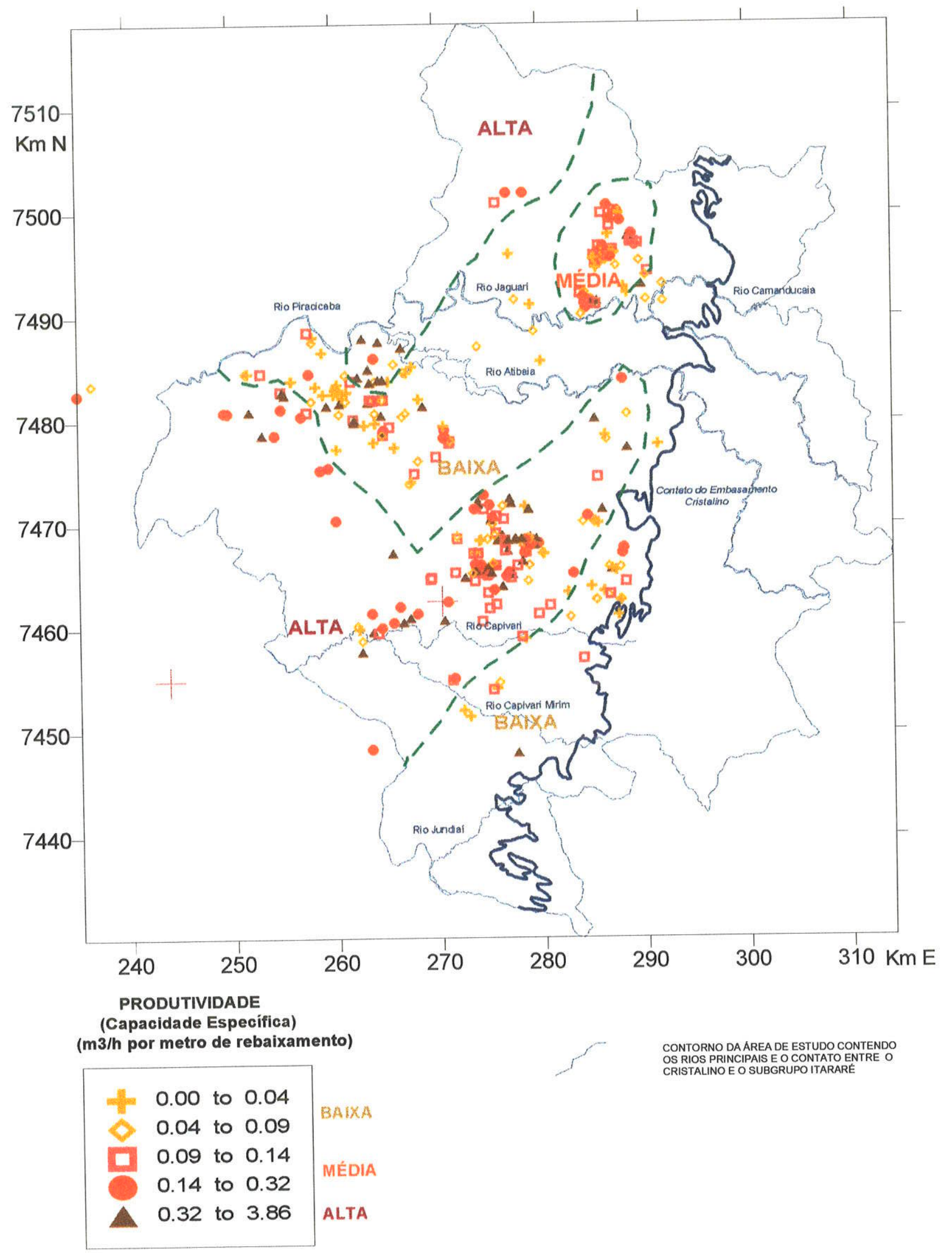

Figura 46 - Distribuição espacial da produtividade no Sistema Aqüífero Tubarão - Aqüífero Itararé 
As regiões com alta potencialidade produtiva são encontradas na porção sudoeste (principalmente Santa Bárbara d'Oeste e Monte Mor), à noroeste (nas proximidades da Represa de Salto Grande, extendendo em faixa para nordeste, englobando a parte oeste de Artur Nogueira e Engenheiro Coelho) e na parte central da área de estudo (oeste de Campinas, Hortolândia e Paulínia).

Esses terrenos altamente produtivo do Aqüifero Itararé estão relacionados com a , disposição de sedimentos mais arenosos de subsuperfície (vide Figura 38).

Em termos de compartimentação estrutural, as maiores produtividades situam-se no Bloco Mumbuca e porção sudoeste-oeste do Bloco Americana (Figura 26), que comportam as maiores espessuras de sedimentos da região. Na porção noroeste do Bloco Americana, oeste do Bloco Pirapitingui e na parte norte do Bloco Capivari, os altos valores de produção dos poços tubulares são encontrados.

Nos poços locados em diabásios, a espacialização das produtividades também apresentou tendências. Os valores baixos encontram-se no corpo aflorante em Campinas. Ao longo da faixa de ocorrência de corpos de diabásios na área de estudo, verifica-se uma alternância de zonas de altas e baixas produtividades, apesar da existência de pouca informação disponível (Figura 47).

Os poços mistos, que exploram mais de um sistema aqüifero/aqüífero, apresentam zonas bem distintas de produtividade. A região de menor potencial situa-se ao longo do contato de embasamento cristalino, seguida de uma área de alta produtividade e de uma de valores intermediários. Na região que engloba principalmente Engenheiro Coelho, Artur Nogueira e Santa Bárbara d'Oeste, a alta produtividade dos poços novamente se faz presente (Figura 48).

As causas das maiores produtividades dos poços mistos podem ser atribuídas por contatos entre unidades aqǘferas distintas (descontinuidades por onde a água subterrânea circula), a maior espessura saturada de sedimentos e litologias arenosas.

Nas porções de borda de bacia, onde ocorrem os menores valores de capacidade específica, os sedimentos são poucos espessos e os contatos entre as unidades aqüiferas muitas vezes encontram-se com revestimento dos poços. 


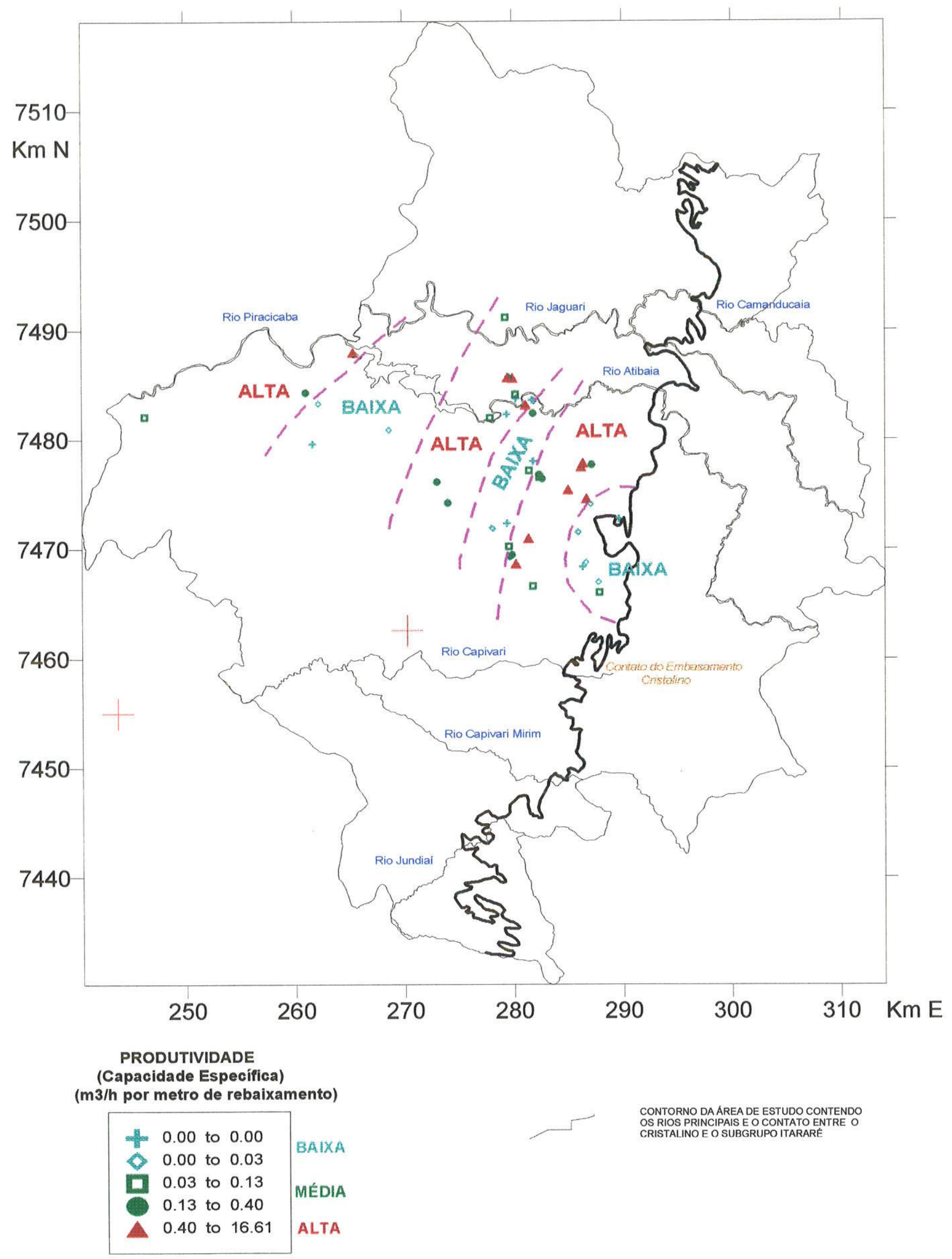

Figura 47 - Distribuição espacial da produtividade em poços locados em diabásios 


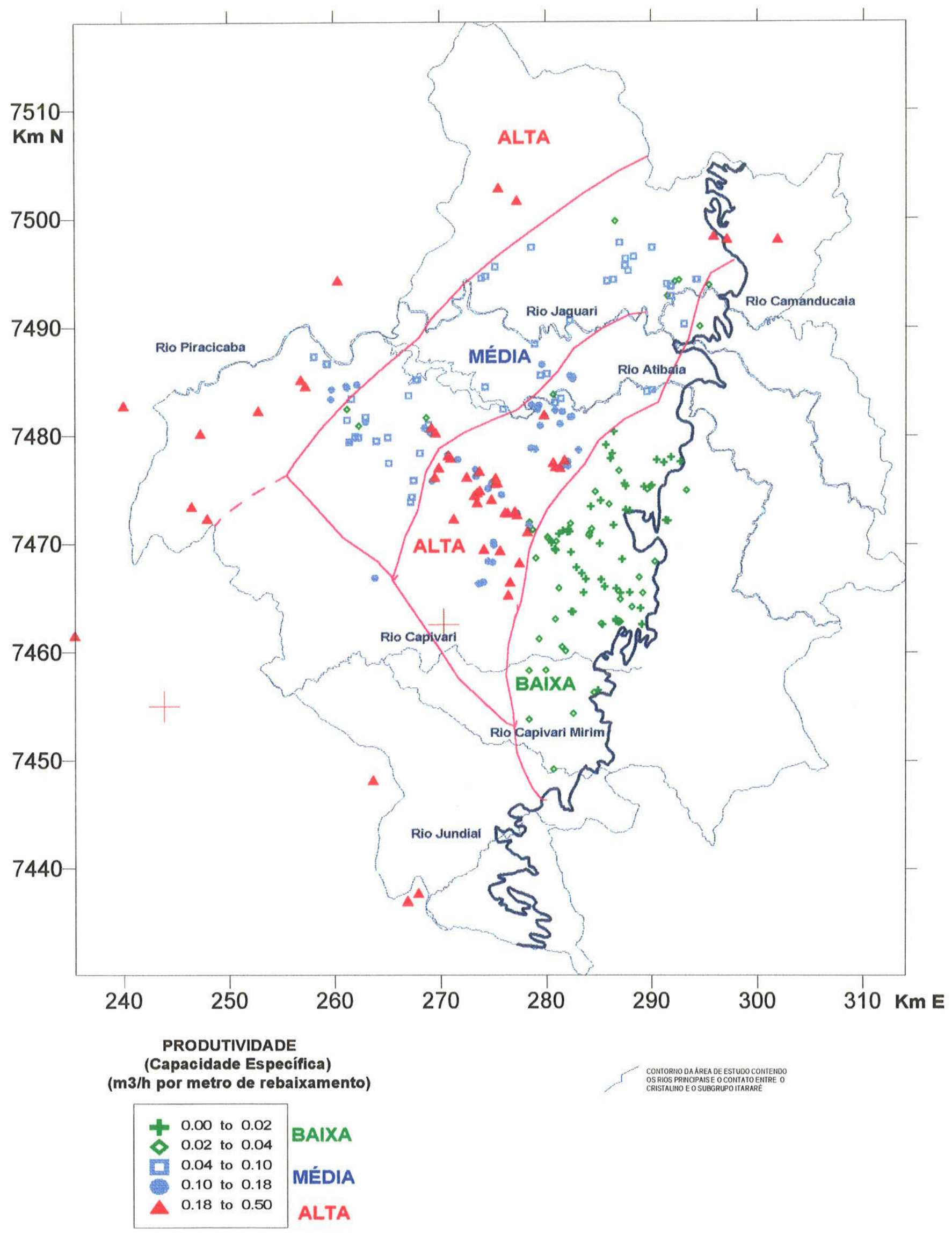

Figura 48 - Distribuição espacial da produtividade dos poços mistos 
À medida que se penetra na bacia sedimentar, a espessura (saturada) aumenta e a produção de água subterrânea das descontinuidades são então computadas, juntamente com a produção da maior espessura saturada.

As zonas de produtividade podem ser correlacionadas com os blocos estruturais encontrados na área. A região de borda de bacia, com baixos valores de capacidade específica, correlaciona-se aos blocos estruturais Capivari e Jaguariúna. A zona de alto . potencial produtivo encontra-se na primeira porção do Bloco Americana. O lineamento de direção NE que corta esse bloco na sua porção central parece ser o limite de compartimentação do alto potencial produtivo para outro de valores intermediários, atingindo também o Bloco Pirapitingui. Por fim um segundo lineamento observado mais a oeste do Bloco Americana e que se extende ao Bloco Pirapitingui delimita a área de alto potencial produtivo.

O sentido de movimentação de alguns blocos estruturais é também concordante com as áreas de maiores produtividades. No Bloco Mumbuca, há um soerguimento com adernamento para sul em direção aos rios Capivari e Tietê, que parece estar concordante com os altos valores de capacidade específica encontradas nos poços ali situados. 


\subsection{DISPONIBILIDADE E CONSUMO DO RECURSO HÍDRICO SUBTERRÂNEO}

A disponibilidade do recurso hídrico subterrâneo foi calculada de acordo com os procedimentos propostos por Lopes (1994) e adaptados para a região de estudo. A tabela 29 apresenta os resultados da disponibilidade por aqüífero e por sub-bacia.

Tabela 29 - Estimativa da disponibilidade da água subterrânea dos sistemas aqüíferos/ aqüíferos por meio de dados de escoamento básico de rios principais por sub-bacias na Região Metropolitana de Campinas (baseado em Lopes 1994).

\begin{tabular}{|c|c|c|c|c|c|c|}
\hline $\begin{array}{l}\text { POSTO } \\
\text { RIO }\end{array}$ & $\begin{array}{c}\text { ESCOAMENTO } \\
\text { BÁSICO } \\
\left(\mathrm{m}^{3} / \mathrm{s} / \mathrm{km}^{2}\right) \\
\end{array}$ & $\begin{array}{l}\text { AQÜífERO } \\
\text { (\% ÁREA) }\end{array}$ & $\begin{array}{c}\text { ÁREA DO } \\
\text { AQÜíFERO } \\
\left(\mathrm{km}^{2)}\right.\end{array}$ & $\begin{array}{c}\text { IINDICE } \\
(\%)\end{array}$ & $\begin{array}{c}\text { VAZÄO } \\
\text { DISPONÍVEL } \\
\left(\mathrm{m}^{3} / \mathrm{s}\right) \\
\end{array}$ & $\begin{array}{c}\text { RESERVA } \\
\text { ANUAL } \\
\left(10^{6} \mathrm{~m}^{3}\right) \\
\end{array}$ \\
\hline $\begin{array}{c}626150 \\
\text { Jaguariúna }\end{array}$ & 0,0047 & Cristalino (100) & 230 & 20 & 0,39 & 12,30 \\
\hline $\begin{array}{c}\text { 4D } 0001 \\
\text { Jaguariúna }\end{array}$ & 0,0074 & \begin{tabular}{|l|} 
Diabásio (15) \\
Itararé (55) \\
Cristalino (30) \\
\end{tabular} & $\begin{array}{c}55 \\
203 \\
111 \\
\end{array}$ & $\begin{array}{l}20 \\
25 \\
20 \\
\end{array}$ & $\begin{array}{l}0,01 \\
0,21 \\
0,05 \\
\end{array}$ & $\begin{array}{l}0,31 \\
6,60 \\
1,60 \\
\end{array}$ \\
\hline $\begin{array}{l}\text { 3D } 003 \\
\text { Atibaia } \\
\end{array}$ & 0,0100 & Cristalino (100) & 397 & 20 & 0,41 & 13,00 \\
\hline $\begin{array}{l}\text { 4D } 009 \\
\text { Atibaia }\end{array}$ & 0,0049 & $\begin{array}{l}\text { Cenozóico (3) } \\
\text { Diabásio (30) } \\
\text { Itararé (42) } \\
\text { Cristalino (25) } \\
\end{array}$ & $\begin{array}{c}10 \\
97 \\
135 \\
81 \\
\end{array}$ & $\begin{array}{l}25 \\
20 \\
25 \\
20 \\
\end{array}$ & $\begin{array}{l}0,0004 \\
0,0300 \\
0,0700 \\
0,0200 \\
\end{array}$ & $\begin{array}{l}0,011 \\
0,897 \\
2,200 \\
0,624 \\
\end{array}$ \\
\hline $\begin{array}{c}\text { 4D } 010 \\
\text { Piracicaba }\end{array}$ & 0,0049 & $\begin{array}{l}\text { Cenozóico (49) } \\
\text { Diabásio (12) } \\
\text { Itararé (32) } \\
\text { Cristalino (7) } \\
\end{array}$ & $\begin{array}{c}388 \\
95 \\
253 \\
55 \\
\end{array}$ & $\begin{array}{l}25 \\
20 \\
25 \\
20 \\
\end{array}$ & $\begin{array}{l}0,230 \\
0,010 \\
0,100 \\
0,004 \\
\end{array}$ & $\begin{array}{l}7,300 \\
0,352 \\
3,100 \\
0,119 \\
\end{array}$ \\
\hline $\begin{array}{c}62420 \\
\text { Capivari }\end{array}$ & 0,0039 & $\begin{array}{l}\text { Cenozóico (17) } \\
\text { Itararé (57) } \\
\text { Cristalino (26) } \\
\end{array}$ & $\begin{array}{c}65 \\
218 \\
100 \\
\end{array}$ & $\begin{array}{l}25 \\
25 \\
20 \\
\end{array}$ & $\begin{array}{l}0,01 \\
0,12 \\
0,02 \\
\end{array}$ & $\begin{array}{l}0,338 \\
3,800 \\
0,636 \\
\end{array}$ \\
\hline $\begin{array}{c}627070 \\
\text { Piracicaba }\end{array}$ & 0,0039 & $\begin{array}{l}\text { Cenozóico (57) } \\
\text { Diabásio (10) } \\
\text { Itararé (32) } \\
\text { Cristalino (1) } \\
\end{array}$ & $\begin{array}{c}476 \\
84 \\
267 \\
8 \\
\end{array}$ & $\begin{array}{l}25 \\
20 \\
25 \\
20 \\
\end{array}$ & $\begin{array}{l}0,260 \\
0,006 \\
0,083 \\
0,006 \\
\end{array}$ & $\begin{array}{l}8,300 \\
0,204 \\
2,600 \\
0,195 \\
\end{array}$ \\
\hline $\begin{array}{l}623950 \\
\text { Jundiaí }\end{array}$ & 0,0061 & $\begin{array}{l}\text { Cenozóico (28) } \\
\text { Itararé (27) } \\
\text { Cristalino (45) }\end{array}$ & $\begin{array}{c}90 \\
87 \\
146 \\
\end{array}$ & $\begin{array}{l}25 \\
25 \\
20\end{array}$ & $\begin{array}{l}0,040 \\
0,036 \\
0,080\end{array}$ & $\begin{array}{l}1,2 \\
1,1 \\
2,5\end{array}$ \\
\hline
\end{tabular}

A vazão disponível total encontrada para a Região Metropolitana de Campinas é de $2,2 \mathrm{~m}^{3} / \mathrm{s}$ ou $69,2 \times 10^{6} \mathrm{~m}^{3} / \mathrm{ano}$, onde $0,54 \mathrm{~m}^{3} / \mathrm{s}$ (17 milhões de metros cúbicos) são provenientes do aqüífero Cenozóico, 0,056 $\mathrm{m}^{3} / \mathrm{s}$ (1,77 milhões de metros cúbicos), do Diabásio, 0,62 m³ (19,5 milhões) do Itararé e $0,98 \mathrm{~m}^{3} / \mathrm{s}$ (30,9 milhões de metros cúbicos) do Cristalino (Tabela 30). 
Tabela 30 - Disponibilidade natural de água subterrânea por sistema aqüífero na Região Metropolitana de Campinas.

\begin{tabular}{|c|c|c|c|}
\hline SISTEMA AQÜIFERO & $\begin{array}{c}\text { AREA EXPOSTA TOTAL } \\
\left(\mathrm{km}^{2}\right)\end{array}$ & $\begin{array}{c}\text { VAZAO DISPONIVEL } \\
\left(\mathrm{m}^{3} / \mathrm{s}\right)\end{array}$ & $\begin{array}{c}\text { RESERVA ANUAL } \\
\left(10^{6} \mathrm{~m}^{3} / \text { ANO }\right)\end{array}$ \\
\hline CENOZOICO & 1029 & 0,540 & 17,00 \\
\hline DIABASIO & 331 & 0,056 & 1,77 \\
\hline ITARARE & 1163 & 0,620 & 19,50 \\
\hline CRISTALINO & 1127 & 0,980 & 30,90 \\
\hline TOTAL & 3650 & 2,200 & 69,20 \\
\hline
\end{tabular}

O valor obtido para o Aqüífero Cenozóico é significante, comparando-se com os demais valores; no entanto, sua pouca espessura e sua situação estratigráfica (sobre os demais sistemas aqüíferos) e topográfica (em topos de colinas) qualifica-o como áreafonte (recarga) para os outros aqüíferos. A maior reserva está contida no Sistema Aqüifero Cristalino, seguido do Itararé.

O valor da disponibilidade natural pode ser somada às perdas pela rede de dsitribuição de água tratada, $17 \%\left(1,02 \mathrm{~m}^{3} / \mathrm{s}\right)$, produzindo um total de $3,22 \mathrm{~m}^{3} / \mathrm{s}(101,5 \underline{x}$ $10^{6} \mathrm{~m}^{3} / \mathrm{ano}$ ) para a Região Metropolitana de Campinas.

A estimativa do consumo de água subterrânea é baseada no número de poços previstos para 1994 na região, onde $70 \%$ (1814 poços) são considerados ativos, e em uma vazão média encontrada, de $6,0 \mathrm{~m}^{3} / \mathrm{h}$, ponderada pelo tempo médio de funcionamento do bombeamento por tipo de atividade econômica. O produto resultante, $1,73 \mathrm{~m}^{3} / \mathrm{s}$ ou 54,6 milhões de metros cúbicos, é a estimativa do consumo total de água subterrânea na área de estudo.

Esse consumo corresponde a uma elevadíssima taxa de exploração $-79 \%$ da reserva ativa natural, ou $54 \%$ da reserva total.

A exploração da água subterrânea por sistema aqüífero é apresentada na tabela 31. 
Tabela 31 - Estimativa de exploração de água subterrânea nos sistemas aqüíferos da Região Metropolitana de Campinas.

\begin{tabular}{|c|c|c|c|}
\hline SISTEMA AQÜIFERO & $\begin{array}{c}\text { NÚMERO DE POÇOS } \\
\text { ESTIMADOS }\end{array}$ & $\begin{array}{c}\text { EXPLORAÇÃO ESTIMADA } \\
\left(\mathrm{m}^{3} / \mathrm{s}\right)\end{array}$ & $\begin{array}{c}\text { EXPLORAC̆ÃO ESTIMADA } \\
\left(10^{6} \mathrm{~m}^{3} / \text { ano }\right)\end{array}$ \\
\hline ITARARE & 637 & 0,57 & 18,0 \\
\hline CRISTALINO & 568 & 0,53 & 16,7 \\
\hline DIABASIO & 86 & 0,06 & 1,8 \\
\hline
\end{tabular}

A estimativa da exploração de água subterrânea revela um maior consumo para o Aqüífero Itararé, seguido do Cristalino.

Esses resultados representam as seguintes taxas de aproveitamento dos aqüíferos: Itararé - 92\%, Cristalino - $55 \%$, Diabásio - -1,0\%. A elevado valor de exploração do aqüífero diabásio cai na incerteza dos valores estimativos, pelo baixos números de poços explorados na região, bem como pela disposição caótica de corpos de diabásio de pequena extensão, em superfície como em subsuperfície. Nos poços do Itararé e Cristalinos foram somados o valor de exploração obtido para os poços mistos.

Essas taxas de aproveitamento indicam o alto consumo das águas subterrâneas nos sistemas aqüiferos da região, principalmente nos sedimentos do Itararé, justificado pela localização dos municípios mais populosos e do parque indústrial da região.

No entanto, não considerou a contribuição significativa dos depósitos cenozóicos nos sedimentos do Itararé, que possui uma reserva ativa de $17,0 \times 10^{6} \mathrm{~m}^{3} / \mathrm{ano}$; caso a contribuição seja total, a taxa de aproveitamento do Aqüífero Itararé é menor e há a redução dos valores pela metade.

Além disso, o Setor Secundário é o maior consumidor de água subterrânea na área de estudo, com exploração de $0,82 \mathrm{~m}^{3} / \mathrm{s}$, seguido do abastecimento público, 0,36 $\mathrm{m}^{3} / \mathrm{s}$, do Setor Primário, $0,33 \mathrm{~m}^{3} / \mathrm{s}$, e por fim do uso particular e do Setor Terciário $(0,12$ e $0,10 \mathrm{~m}^{3} / \mathrm{s}$ respectivamente).

As regiões compreendidas principalmente por Campinas, Valinhos, Hortolândia, Sumaré, Paulínia, Nova Odessa, seguida dos municipios de Santa Bárbara d'Oeste, Americana, Monte Mor e Indaiatuba, apresentam os maiores índices de consumo da água subterrânea na área de estudo, pois compreendem o eixo de industrialização dessa região metropolitana. O Setor Secundário é o maior usuário da água subterrânea, 
seguido pelo uso particular; o Setor Primário surge como consumidor de porte na porção nordeste da área, especialmente Holambra, com $96 \%$ de poços usados na agropecuária. Os demais municípios, como Engenheiro Coetho, Artur Nogueira, Cosmópolis, Santo Antonio da Posse, Jaguariúna e Pedreira caracterizam-se pelo baixo consumo de água subterrânea, cujo principal usuário é ainda o Setor Primário, caracterizado pelas atividades essencialmente agrícolas e pecuárias (Figura 49).

¿É interessante observar que o consumo de água subterrânea pelo Setor Terciário só é relevante no município de Campinas, que é o pólo irradiador da ocupação urbana e industrial da região, e provavelmente o centro comercial da região; acredita-se que com o crescimento da atividade econômica terciária no município, exista um aumento do número de consumidores de água subterrânea neste setor.

No Setor Primário, os maiores usuários consistem de sítios e fazendas com atividade agrícola e pecuária (aves, gado, suínos e cavalos); em Holambra, destacam-se a suinocultura e granjas e a plantação de flores e plantas ornamentais. Em Pedreira, a principal usuária da água subterrânea é a atividade de mineração (cerâmicas, principalmente).

$\mathrm{Na}$ área mais industrializada, na porção central e a oeste da região metropolitana, destacam-se como maiores usuários as indústrias têxteis, química/petroquímica, eletroeletrônica, metalúrgica, civil e alimentícia, dentre outros. A grande maioria das indústrias da região capta água além da rede pública, explorando a água subterrânea, ou o recurso de drenagens vizinhas.

Os usuários particulares são caracterizados pelas pessoas jurídicas ou físicas que usam a água subterrânea para abastecimento doméstico; os loteamentos, chácaras de lazer, e residência, consistem dessa classe de consumidor de água subterrânea, que geralmente não possuem rede de distribuição pública.

Os usuários do Setor Terciário é o comércio (lojas, postos de gasolina, restaurantes, clubes, hotéis/motéis, etc.) e do abastecimento público, os serviços municipais (SEMAE, SAEE, SAMAE e SABESP) que exploram a água subterrânea para abastecimento de comunidades que não possuem rede pública de distribuição. 


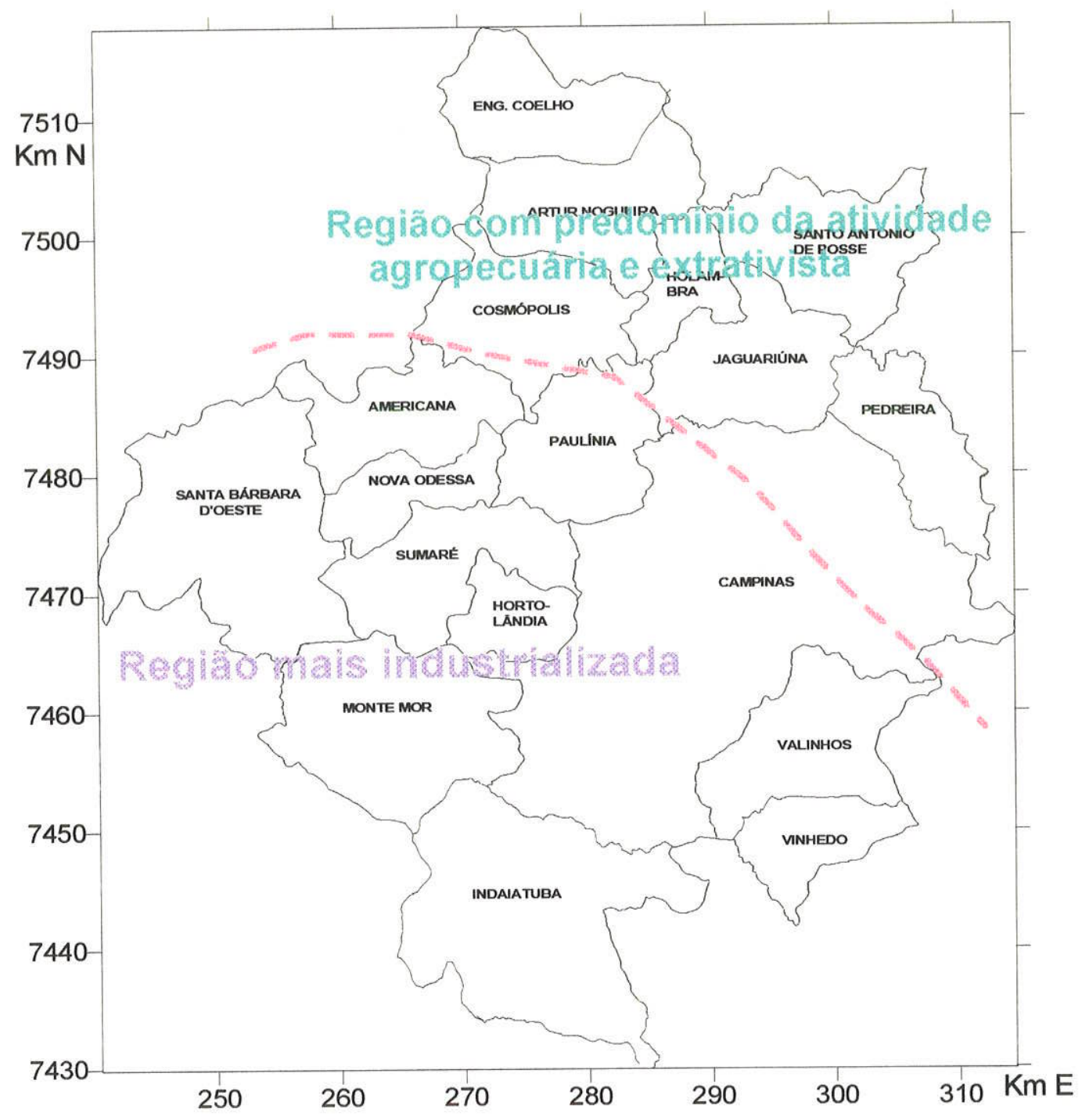

CONSUMO DA ÁGUA SUBTERRÂNEA POR MUNICÍPIO ( em $10^{6} \mathrm{~m}^{3} / \mathrm{ano}$ )

\begin{tabular}{|l|c|c|c|c|c|}
\hline \multirow{2}{*}{ MUNICIPIOS } & \multicolumn{3}{c|}{ SETOR } & \multicolumn{2}{c|}{ SANEAMENTO } \\
\cline { 2 - 6 } & PRIMÁRIO & SECUNDÁRIO & TERCIÁRIO & PARTICULAR & PÚBLICO \\
\hline CAMPINAS & 2,5 & 8,2 & 1,9 & 0,9 & 5 \\
INDAIATUBA & 0,63 & 1,26 & 0,04 & 0,41 & 0 \\
MONTE MOR & 0,9 & 1,4 & 0,06 & 0,35 & 0,25 \\
SANTA BÁRBARA D'OESTE & 0,09 & 1,2 & 0 & 0,16 & 1,8 \\
HORTOLÂNDIA & 0,22 & 1,42 & 0,01 & 0,17 & 0,38 \\
SUMARÉ & 0,09 & 1,36 & 0,06 & 0,05 & 0,21 \\
NOVA ODESSA & 0,19 & 2,05 & 0,09 & 0,19 & 0,16 \\
AMERICANA & 0,02 & 1,9 & 0,15 & 0,25 & 0,25 \\
PAULINIA & 0,09 & 1,83 & 0,35 & 0,02 & 0,16 \\
COSMÓPOLIS & 0,13 & 0,13 & 0,03 & 0,23 & 0,05 \\
ARTUR NOGUEIRA & 1,47 & 0,25 & 0,13 & 0,04 & 0,88 \\
ENGENHEIRO COELHO & & & & & 0 \\
HOLAMBRA & 2,1 & 0 & 0 & 0,02 & 0 \\
JAGUARIÚNA & 0,63 & 0,25 & 0,09 & 0,15 & 0,16 \\
SANTO ANTONIO DA POSSE & 0,06 & 0,16 & 0 & 0,09 & 0 \\
PEDREIRA & 0,63 & 0,13 & 0 & 0,05 & 0,16 \\
VALINHOS & 0,88 & 3,03 & 0,38 & 0,79 & 1,32 \\
VINHEDO & 0,6 & 1,6 & 0 & 0,2 & 0,2 \\
\hline
\end{tabular}

Figura 49 - Consumo da água subterrânea por município na Região Metropolitana de Campinas 


\section{PLANEJAMENTO E MEIO AMBIENTE}

$\mathrm{Na}$ avaliação das várias metodologias de estudos do meio físico para subsidiar o planejamento territorial e/ou a análise ambiental, reconheceram-se dois tipos de enfoque, que fundamentam estudos distintos.

A Geologia Ambiental, Geotecnia e Geologia de Engenharia, pelas suas próprias definições, têm como ponto de referência o Homem, isto é, são ciências aplicadas que procuram compreender a relação (principalmente a interferência) do homem no habitat geológico. As ramificações Geologia de Áreas Urbanas e Geologia de Planejamento

- Urbano são frutos também dessa linha de pesquisa. Os estudos são essencialmente aplicados, cuja meta é o desenvolvimento de métodos ou procedimentos de caráter (geo)técnico para propor soluções aos impactos existentes ou potenciais e determinar aptidões ou restrições à qualquer tipo de ocupação antrópica (neste caso, relativos as obras de engenharia). Em vista disso, há uma preocupação da quantificação de parâmetros nesses estudos. As cartas geotécnicas e as cartas de síntese (ou de zoneamento geotécnico) são os recursos de representação gráfica utilizadas para fins de planejamento.

Outras metodologias de análise do meio físico são a abordagem da paisagem e ecologia da paisagem, onde a geomorfologia é a geociência que embasa estes estudos. Neste conceito, a ocupação do solo está intimamente vinculada à paisagem, que é o catalisador dos processos morfodinâmicos naturais. Esta abordagem procura entender o ambiente em sua totalidade, onde todos os parâmetros analisados estão interrelacionados e são interdependentes. É uma visão holística do ambiente, e com base neste entendimento "total" pode-se chegar a soluções de problemas e propor diretrizes para um planejamento ótimo do uso do solo. Neste conceito, a posição do homem é participativa, onde o ambiente é o centro referencial desta abordagem. A abordagem da paisagem têm um visão "naturalista"e caráter qualitativo, e inicialmente era utilizada para o levantamento de recursos naturais em áreas desconhecidas.

Esta visão holística é representada na cartografia por meio de uma taxonomia de tipos de unidades, relativas aos graus de sensibilidade do ambiente em função dos fenômenos naturais e antrópicos (Tricart 1977). As cartas resultantes são classificadas 
em cartas de análise, de síntese, de aptidão e sensibilização (Journaux 1975, 1985 apud Martinelli 1994).

Assim os estudos "geoambientais"(entendido aqui como sendo as geociências parte integrante do ambiente) como a Abordagem da Paisagem, são avaliações regionais de áreas de grandes extensões e consequentemente de escalas de trabalho pequenas. A cartografia geotécnica e da geologia de engenharia requer estudos de - major escala, pela sua própria definição e sua necessidade de quantificação.

O termo geologia ambiental conceituado por Flawn (1983 apud Cottas 1983) possui forte conotação aplicada, onde esta ciência "deve estudar e apresentar soluções para os problemas ocorrentes do uso do solo pelo homem", e enfim, "estabelecer o " equilibrio nas relações homem-habitat geológico". No entanto, este conceito pode ser mais abrangente; atualmente são comuns trabalhos multidisciplinares em que se busca um entendimento maior do ambiente através da interação de diversas áreas do conhecimento. A geologia (e seus vários campos de estudo) deve procurar a compreensão de seu papel dinâmico dentro deste contexto maior, que é o ambiente e de suas interrelações com as demais ciências físicas, humanas e biológicas.

Esse entendimento de caráter holístico aplica-se também numa melhor solução de impactos "geoambientais" provocados pelo agente antrópico, e a um planejamento ótimo de uso e ocupação do solo e ao gerenciamento dos recursos naturais.

Esta visão, portanto, vem de encontro com as idéias de "desenvolvimento sustentável" para o ambiente em que se vive.

No entanto, estes dois enfoques distintos são complementares nos estudos de planejamento territorial e gerenciamentos de recursos. Os estudos hidrogeológicos propostos neste trabalho visam: compreender as condições de ocorrência da água subterrânea e suas interrelações com a dinâmica do meio físico e biótico; e em relação ao homem, a análise como recurso hídrico subterrâneo e como um atributo do terreno frente aos usos e tipos de ocupação.

Este entendimento global da água subterrânea pode fornecer subsídios realmente eficientes para um gerenciamento "sustentável" do recurso e diretrizes/recomendações mais confiáveis sobre a mitigação de impactos e proteção/preservação deste ambiente aquático, assim como em compreender e aprofundar os conhecimentos das águas 
subterrâneas, entender a sua posição dentro do ciclo hidrológico/ambiente e as interelações com outros parâmetros do meio físico.

\subsection{DEFINIÇÃO DAS UNIDADES HIDROGEOLÓGICAS}

As unidades hidrogeológicas foram compartimentadas com a finalidade de retratar espacialmente o comportamento das águas subterrâneas, as condições naturais de sua ocorrência e as relações entre os demais atributos do meio físico na área de estudo, envolvendo estudos hidrogeológicos básicos.

A análise das condições naturais de ocorrência das águas subterrâneas envolve o conhecimento litológico e estrutural (de superfície e subsuperfície) das rochas armazenadoras e condutoras de água subterrânea, a análise do relevo, do solo e de suas condições genéticas e das drenagens existentes, e da caracterização hidroclimática na área de estudo.

$\mathrm{Na}$ definição dessas unidades destacam-se a hidrodinâmica da água subterrânea, a determinação de áreas de recarga e descarga, e os locais onde as condições de circulação sejam diferenciadas em função da ocorrência de litologias e estruturas especificas. Os estudos envolvidos são: geometria dos aqüiferos, potenciometria e/ou espacialização dos níveis de água, análise do relevo e processos morfodinâmicos, pedologia e/ou material inconsolidado e hidroclimatologia.

A elaboração da carta de unidades hidrogeológicas baseou-se na análise integrada dos mapas potenciométrico, das cartas de unidades climáticas e de unidades de terreno, mapa geológico, de contorno estrutural do embasamento e da compartimentação de blocos estruturais. Os resultados dessa análise e da superposição desses mapas produziram os limites das Unidades Hidrogeológicas.

Os trabalhos foram elaborados em escala de trabalho 1:100.000, e apresentados na escala 1:200.000.

A área de estudo foi compartimentada em quatro unidades hidrogeológicas, em função principalmente da circulação das águas subterrâneas e dos sistemas aqüíferos encontrados (Anexo 3). 
Assim, as unidades foram assim classificadas: $\mathrm{Cl}$ e $\mathrm{Cll}$ - correspondentes ao Sistema Aqüífero Cristalino; c e áreas em branco - correspondentes aos depoósitos cenozóicos e ao Aqüífero Itararé, e o - aluviões. Nas unidades sedimentares, encontramse duas sub-unidades, de ocorrência sub-superficial que interferem nas condições de ocorrência da água subterrânea no Aqüífero Itararé: os corpos de diabásio (d), compostos por corpos de extensão limitada e dispostos em diversos níveis de , profundidade, porém em zona de ocorrência bem definida; e os sedimentos predominantemente arenosos (a), encontrados em sub-superficie, também ocorrentes em regiões bem definidas. A subzona $m$ apresenta o pacote sedimentar mais espesso e é delimitado pelo bloco estrutural Mumbuca (Pires Neto 1996).

A zona $\mathrm{Cl}$ engloba praticamente os terrenos escarpados constituidos pelas rochas graníticas do Granito Morungaba; caracterizam-se pela ocorrência das áreas mais elevadas da região, presença de solos rasos e de rochas expostas. Os níveis do freático são indicados pela presença de muitas nascentes na rocha. A alta densidade de drenagem é indicativa de um alto grau de fraturamento, corroborada pelo padrão subparalelo a subdendrítico.

A disposição dos niveis potenciométricos da região indicam ser a zona $\mathrm{Cl}$ uma área de recarga regional, com altos valores de gradiente hidráulico.

A zona Cll, também constituída pelo Sistema Aqüifero Cristalino, é representada pelos terrenos de montanhas, morros e morrotes, suportadas pelas rochas gnáissicas e graníticas do Complexo Itapira e Granito Itu. A região apresenta cotas topográficas elevadas, terrenos acidentados e forte estruturação. A densidade de drenagem é considerada moderada em relação à primeira citada. A presença do manto de alteração de textura argilo-arenosa em profundidades significativas, supõe um segundo modo de ocorrência das águas subterrâneas: por porosidade primária.

Essa região apresenta os maiores valores de pluviometria e excedente hídrico; a deficiência hídrica média praticamente é considerada nula.

Em termos qualitativos, as regiões $\mathrm{Cl}$ e $\mathrm{Cll}$ podem ser classificadas como possuidores de médio a bom potencial de infiltração, haja visto a alta pluviometria, solos rasos (no caso de $\mathrm{Cl}$ ) e alto grau de fraturamento. As condições desfavoráveis são a alta declividade que ocasiona um alto valor escoamento superficial, dificultando a recarga na área. 
As zonas sedimentares são as regiões onde estão aflorantes os diabásios, os depósitos cenozóicos e sedimentos (em sua maioria sedimentos arenosos) do Itararé; consistem de topos das colinas amplas e de topos sub-horizontalizados e de divisores locais das águas subterrâneas. O fluxo das águas subterrâneas divergem nesses locais, dirigindo-se às drenagens existentes em cotas menores; essas zonas são consideradas áreas locais de recarga. As condições de infiltração são consideradas boas, atribuindo a isso, as baixas declividades dos terrenos, boa permeabilidade dos depósitos cenozóicos e dos solos Latossolo Vermelho Amarelo e Roxo, indicada pela baixa densidade de drenagem ocorrente, alta pluviometria e excedente hídrico com baixos valores de deficiência.

As zonas sedimentares em branco na carta são terrenos constituídos pelos sedimentos mais pelíticos do Itararé, e encontrados em relevos colinosos, porém com maior grau de ondulação (abrangem desde colinas pequenas a colinas médias e amplas). O potencial de infiltração é considerado baixo para essas zonas, pela presença de litologias de baixa permeabilidade (indicadas pela densidade de drenagem moderada), e de solos Podzólicos Vermelho Amarelo, de textura argilo-siltosa a arenoargilosa.

Nas zonas sedimentares, encontram-se discriminados três unidades de subsuperficie: a subzona d, onde há ocorrência de corpos de diabásio em superfície e subsuperfície; a subzona a, região onde há a presença de litologias mais arenosas do Itararé, e a subzona $\mathrm{m}$, restrita à zona localizada a sudoeste, que corresponde a delimitação do bloco estrutural Mumbuca, onde são encontrados os pacotes sedimentares mais espessos, e consequentemente, com fluxos de água subterrânea mais profundos e regionais.

A última unidade, a zona o, são correspondentes aos aluviões; são considerados as áreas de descarga regional (em rios de maior porte como o Piracicaba, Jaguari, Atibaia, Capivari, Capivari Mirim e Quilombo) e local das águas subterrâneas, e estão situados nas cotas topográficas mais baixas, próximos aos niveis de base dos rios e possuidores de níveis de água subaflorante a aflorante. 


\subsection{CARTA DE APTIDÕES}

\subsubsection{Produtividade}

O zoneamento das áreas com as classificações da produtividade dos poços - tubulares profundos foram fundamentadas pelos resultados da caracterização hidrodinâmica, conjuntamente com seus condicionantes litológicos e estruturais, relatados no capítulo anterior.

As produtividades dos poços, representadas pelos valores de capacidade específica, foram agrupadas em função da classificação em alta, média e baixa, para cada tipo de aqüífero.

Essa classificação foi baseada na disposição espacial e da concentração de valores de capacidade específica de um mesmo intervalo.

Os resultados espaciais dessa caracterização hidrodinâmica por aqüíferos foram integrados, definindo zonas de produtividade de mesma graduação.

O mapa resultante está representado na Anexo 4, juntamente com a descrição dos principais condicionantes da produtividade dos aqüíferos locais e recomendações para obtenção de uma melhor produção.

As áreas de maiores produtividades encontram-se distribuídas na porção oeste e central da região analisada. No Sistema Aqüífero Cristalino, as produtividades mais significativas localizam-se ao sul, à leste e em uma faixa que se extende em sentido SSW a NNE (em torno da Zona de Cisalhamento de Valinhos). As áreas de produtividade baixa são encontradas no contato da borda da Bacia Sedimentar do Paraná, e entre as zonas de cisalhamento Valinhos e Campinas. Os locais com produtividade intermediária situam-se em uma faixa na porção central que se extende para NE e ao sul da área, no embasamento cristalino (Anexo 4). 


\subsubsection{VULNERABILIDADE NATURAL}

A vulnerabilidade natural dos aqüiferos foi determinada utilizando os seguintes parâmetros: unidades de terreno, nível de água dos poços tubulares profundos, geologia, geomorfologia e espessura do material de alteração em rochas cristalinas.

O critério discriminador da graduação da classificação da vulnerabilidade natural , do terreno, foi o nível de água nos intervalos 0-10 m,10-20 m e acima de $20 \mathrm{~m}$, e as unidades de terreno (que é a síntese da caracterização do meio físico), no que se refere ao sua permeabilidade relativa e potencial de infiltração.

Os aluviões foram considerados como de vulnerabilidade alta, pois apresentam - níveis de água sempre subaflorante a aflorante, sendo considerados como pontos de descarga local e regional de água subterrânea.

Nessa avaliação o Sistema Aqüifero Cristalino foi analisado: nas áreas de maiores altitudes, onde há ocorrência de terrenos escarpados e de rochas graniticas do Granito Morungaba, a vulnerabilidade natural é considerada alta. Os fatores que levaram a essa classificação foram a presença de solos rasos e rochas aflorantes na área (isto é, a ausência de fatores de atenuação), maior densidade de fraturamentos e a alta pluviometria, que induz a uma maior capacidade e rapidez de infiltração e transportes de possíveis contaminantes.

O manto de alteração com espessuras significativas existentes nas rochas cristalinas foi considerado na classificação da vulnerabilidade natural, nas demais áreas do embasamento cristalino.

A classificação da vulnerabilidade natural dos sistemas aqüiferos foi graduada em alta, média e baixa, e estão representadas na Carta de Vulnerabilidade Natural dos Aqüiferos (Anexo 5).

Em síntese, as classificações estão apresentadas na Tabela 32. 
Tabela 32 - Classificação da vulnerabilidade natural dos Sistemas Aqüíferos na Região Metropolitana de Campinas - SP.

\begin{tabular}{|c|c|c|c|}
\hline VULNERABILIDADE & $\begin{array}{l}\text { NIVEL DE AGUA } \\
(\mathrm{m})\end{array}$ & $\begin{array}{l}\text { UNIDADE DE } \\
\text { TERRENO }\end{array}$ & $\begin{array}{l}\text { SOLO I LITOLOGIA } \\
\text { PREDOMINANTE }\end{array}$ \\
\hline \multirow[t]{2}{*}{$\overline{A L T A}$} & \multirow[t]{2}{*}{$0-10$} & $\begin{array}{l}9 \\
8\end{array}$ & $\begin{array}{l}\text { Aluviōes } \\
\text { Latossolo Vermelho Amarelo-Depósitos Cenozóicos e } \\
\text { sedimentos arenosos do Itararé }\end{array}$ \\
\hline & & $\begin{array}{c}1,4 \\
\text { (2 secundário) }\end{array}$ & $\begin{array}{l}\text { Solos Podzólicos (rasos) e Litólicos- rochas } \\
\text { graníticas do Granito Morungaba e Granitóide } \\
\text { Jaguariúna }\end{array}$ \\
\hline \multirow[t]{4}{*}{ MEDIA } & $0-10$ & 3,5 & $\begin{array}{l}\text { Podzólico Vermetho Amarelo (manto de alteraçăo) } \\
\text { dos gnaisses do Complexo Itapira }\end{array}$ \\
\hline & \multirow[t]{3}{*}{$10-20$} & 6,7 & $\begin{array}{l}\text { Podzólico Vermelho Amarelo - Sedimentos pelíticos } \\
\text { do Itararé. }\end{array}$ \\
\hline & & 2,4 & $\begin{array}{l}\text { Podzólico Vermelho Amarelo e Litólicos - rochas } \\
\text { graníticas do Granito Morungaba e gnaisses do } \\
\text { Complexo Itapira }\end{array}$ \\
\hline & & 8 & $\begin{array}{l}\text { Latossolos Vermelho Amarelo e Roxo - Depósitos } \\
\text { Cenozóicos e sedimentos arenosos do Itararé }\end{array}$ \\
\hline \multirow[t]{3}{*}{ BAIXA } & $10-20$ & 3,4 & $\begin{array}{l}\text { Podzólico Vermelho Amarelo (manto de alteração) } \\
\text { dos gnaisses do Complexo Itapira }\end{array}$ \\
\hline & \multirow[t]{2}{*}{ maior 20} & 6,7 & $\begin{array}{l}\text { Podzólico Vermelho Amarelo - Sedimentos pelíticos } \\
\text { do Itararé }\end{array}$ \\
\hline & & 1 a 8 & $\begin{array}{l}\text { Todos tipos de solo e as litologias, excetuando os } \\
\text { aluviőes }\end{array}$ \\
\hline
\end{tabular}




\subsection{CARTA ORIENTATIVA AO USUÁRIO DAS ÁGUAS SUBTERRÂNEAS}

A carta orientativa ao usuário das águas subterrâneas é a síntese das informações contidas nesse trabalho que são relevantes ao planejamento e a análise ambiental.

Nela estão representados as maiores potencialidades e fragilidades existentes sobre o recurso hídrico subterrâneo, descrevendo as características do potencial produtivo e das fragilidades natural do meio.

Basicamente, este mapa é a síntese das cartas de aptidões, e pode ser classificada como carta orientativa ou de sensibilização.

A Carta Orientativa ao Usuário das Águas Subterrâneas (Anexo 6) contém as regiões de alta produtividade do poços, com informações especificas sobre esse potencial, de acordo com as características do sistema aqüífero, e recomendações sobre critérios de perfuração de poços tubulares profundos.

As zonas de maior vulnerabilidade de ocorrência de diabásios foram considerados como as fragilidades do meio; as recomendações quanto às limitações do uso desses terreno foram descritos no mapa.

As informações sobre a reserva disponivel (ou ativa), tipo de uso e consumo da água subterrânea, a taxa geral de aproveitamento dos aqüiferos, assim como a produção média de água por poço e a estimativa do número de pessoas que podem ser abastecidas por poço, por dia foram considerados na legenda.

Os terrenos escarpados, situados a leste da área de estudo, foi definida como área potencial para preservação, devido sua vulnerabilidade alta, posição topográfica, ocorrências de nascentes e principalmente como área de recarga regional e recurso paisagístico.

Por fim, as legislações existentes sobre a exploração da água subterrânea são descritas com o objetivo de informar ao usuário da carta, das normas e procedimentos legais. 


\section{CONCLUSÕES}

Os estudos hidrogeológicos executados na Região Metropolitana de Campinas visaram aprofundar o conhecimento do modo de ocorrência da água subterrânea em regiões situadas na borda da Bacia Sedimentar do Paraná.

A circulação das águas subterrâneas caracteriza-se por um sistema de fluxo de caráter local, em que a topografia dos terrenos possul influência direta no direcionamento das linhas de fluxo.

A caracterização hidrogeológica dos sistemas aqüíferos regionais, Tubarão (no caso o Aqüifero Itararé) e Cristalino, as ocorrências de diabásios e os depósitos cenozóicos determinou a influência dos condicionantes estruturais na delimitação da geometria dos aqüiferos e na hidrodinâmica das águas subterrâneas.

O Sistema Aqüífero Cristalino, situado na porção leste da área, é composto pelas rochas gnássicas e graníticas do Complexo Itapira e dos Granitos Morungaba e Itu, e do Granitóide Jaguariúna, possuidores de idades que variam de proterozóico médio, passando ao neo-proterozóico a cambro-ordoviciano.

As estruturas de grande porte compartimentam esse sistema em blocos estruturais, e são responsáveis pela circulação de água subterrânea, como também pela maior ou menor produtividade dos poços, juntamente com as fraturas e falhas normais existentes. A presença de manto de alteração com espessuras significativas em parte da área, impõe um modo de ocorrência das águas subterrâneas por porosidade primária na parte superior desse sistema aqüifero.

O Sistema Aqüífero Tubarão, representado na região metropolitana pelo Aqüífero Itararé, está aflorante na sua porção central e oeste. Os sedimentos pelíticos representam ambientes deposicionais de ambiente de plataforma e de retrabalhamento de depósitos glaciais em ambiente marinho, enquanto que as associações de arenitos resultaram da deposição de ambientes deltáicos. O pacote sedimentar aumenta sua espessura para oeste da área, porém há a existência de "altos" e "baixos" estruturais de direção NE sotoposto a esse pacote. 
Em subsuperfície, há a ocorrência de sedimentos arenosos em uma faixa de grande extensão, cortando em sentido NW-SE, situada no quadrante sudoeste da área de estudo.

A produtividade dos poços nesse sistema aqüifero está condicionada à ocorrência desses sedimentos arenosos de subsuperfície, como também pela maior espessura do pacote sedimentar e pelas estruturações da rocha.

Em diabásios, a produtividade de poços tubulares está condicionada aos fraturamentos da rocha.

Nos poços mistos, a maior produtividade se encontra na combinação dos sistemas aqüíferos Itararé/Diabásio. A espacialização dos valores de capacidade específica revelou tendências bem distintas, onde as áreas de menor potencial se encontra próximos ao contato do embasamento cristalino e as de maior potencial, em faixas de direção NE, ao longo da região de estudo.

A produtividade dos poços na Região Metropolitana de Campinas está relacionada também às movimentações neotectônicas dos blocos estruturais definidos na área. A tendência de maior produtividade dos poços nos locais de caimento dos blocos estruturais é notória, exemplificando com os blocos Mumbuca, Itu, Jaguariúna e Americana. Nesse último bloco, há dois comportamentos distintos de produtividade, cuja delimitação entre estas duas graduações é um lineamento de d cagem que corta esse bloco estrutural e se prolonga até o Bloco Pirapitingui.

No tocante a caracterização do uso e consumo do recurso hídrico subterrâneo, o perfil sócio-econômico é um fator de relevância nessa análise pois a maior intensidade de exploração dos poços está vinculado diretamente com o tipo de atividade econômica da região, seu grau de desenvolvimento e da relação reserva/demanda de água atual.

A Região Metropolitana de Campinas, face ao seu local estratégico, sempre se caracterizou como pólo de desenvolvimento econômico na região, em diversos períodos da história.

$O$ alto desenvolvimento industrial e, consequentemente, populacional, promoveu atualmente uma região de conurbação que se inicia em Campinas e se extende até Piracicaba, causando problemas inerentes a uma ocupação desordenada e não controlada, que se soma a um período de crise econômica e recessão. 
Nessa área existe ainda o problema da escassez, em quantidade e qualidade, do recurso hídrico por limitações da bacia hidrográfica dos rios Piracicaba e Capivari em comportar tamanha demanda local, com o agravante do fornecimento de água potável para o Sistema Cantareira, São Paulo.

A crescente utilização da água subterrânea na Região Metropolitana de Campinas é conseqüência dessas duas situações expostas.

"A água subterrânea, considerada como um recurso estratégico, se transforma em recurso principal em locais/loteamentos carentes de saneamento público, nas pequenas a médias indústrias, em atividades primárias como a agropecuária e mineração, em atividades essenciais (hospital, escola, etc..) e áreas de lazer (chácaras, clubes, etc..).

É um recurso opcional para grandes empresas, fazendas e serviços públicos de saneamento básico, pois a água subterrânea é praticamente um recurso gratuito, havendo apenas as despesas de custeio da construção da obra de captação, instalação e manutenção do equipamento de extração da água.

Na Região Metropolitana de Campinas, estima-se um número de 2461 poços tubulares profundos existentes, em que 1723 encontram-se ativos. O tipo de uso da água subterrânea retrata o perfil sócio-econômico da região: por exemplo, em Holambra cerca de $96 \%$ do uso da água subterrânea é atribuída a atividade agropecuária; em Paulínia, as indústrias são as maiores consumidoras, e em Pedreira, a atividade de mineração é uma usuária significativa desse recurso hídrico.

O município de Campinas é o maior consumidor do recurso hídrico subterrâneo, seguido em menores proporções os municípios de Valinhos, Paulinia, Nova Odessa e Americana.

Em geral, a atividade econômica secundária, caracterizada pelas indústrias, é o setor econômico que mais se utiliza da água subterrânea, seguida pelo uso de particulares para saneamento doméstico.

A estimativa da reserva ativa em relação ao consumo revela um alto índice de exploração: cerca de $79 \%$ da reserva natural ou $54 \%$ da reserva total são exploradas na Região Metropolitana de Campinas, e uma maior taxa de aproveitamento do Aqüífero Itararé, seguido do Cristalino. Esse alto consumo, em detrimento a estimativa da reserva ativa justifica-se pela alta taxa de urbanização da área, escassez de água superficial em 
qualidade e quantidade e pelo uso indiscriminado do recurso, que apesar da existência de leis, essas ainda não estão efetivamente sendo aplicadas.

Apesar da existência da lei estadual $n^{\circ} 6.134(02 / 06 / 88)$ e de sua regulamentação (Decreto $n^{\circ} .32 .955$ de 07/02/91) e da Portaria DAEE $n^{\circ} 12$ (14/03/91), que dispõem sobre a preservação das águas subterrâneas e as normas de licença de execução e operação de poços tubulares profundos, não há efetivamente o cumprimento até os dias atuais, como pode ser observado pelo número de poços existentes na área com o cadastro oficial do DAEE e pelos trabalhos de campo.

Em 1996, foi instituído o processo de outorga da água subterrânea (Portaria DAEE $n^{\circ} 167$ de 16/05/96), para disciplinamento do uso do recurso hídrico superficial e subterrâneo.

A aplicação dessas leis são o primeiro passo para a implementação de um plano gerencial dos recursos hídricos subterrâneos, uma vez que definem diretrizes e normas gerais para preservação e disciplinamento do uso do recurso.

A conscientização de organismos municipais e intermunicipais para a normatização desse recurso, em caráter local também se faz necessária.

A situação na Região Metropolitana de Campinas é um exemplo típico do uso indiscriminado do recurso hídrico subterrâneo, que possui uma reserva ativa limitada, e um alto consumo.

A tendência do crescimento do uso desse recurso é visível, haja visto as limitações da quantidade e qualidade das águas superficiais na região, e do aumento da demanda causada pelo consequente aumento da demografia da área.

Dessa forma, a informação da situação dos recursos hídricos subterrâneos devem ser transmitidas aos organimos de decisão local, de modo que esses possam ter um diagnóstico global da situação e de suas tendências futuras, para compor um plano de gestão do recurso na área.

As cartas de planejanento e análise ambiental foram desenvolvidas com a finalidade de subsidiar os estudos do meio físico com enfoque a esses temas, como também auxiliar diretamente o usuário na tomada de decisões ou na elaboração de leis de preservação ou no manejo de recursos naturais. 
A metodologia consiste na elaboração de uma carta síntese das condições de ocorrência, integrando o conhecimento do meio físico existente com as águas subterrâneas, em carta analítica ou carta descritiva; na elaboração de cartas de aptidão ou cartas interpretativas (também denominadas de mapas de único propósito e cartas de orientação) e da carta de múltiplos propósitos ou mapas de sensibilização.

A Carta de Unidades Hidrogeológicas é a carta síntese das condições de ocorrência das águas subterrâneas, elaborada através da integração das informações do meio físico, clima e balanço hídrico com a caracterização das condições de fluxo e geometria dos sistemas aqüíferos da área de estudo.

Os mapas de produtividade e de vulnerabilidade natural dos aqüíferos são cartas - interpretativas com a finalidade de apresentar aptidões do meio físico da área de estudo quanto a esses temas, e que são importantes para a avaliação do recurso hídrico para o planejamento de uso e ocupação do solo, como também na análise geoambiental.

A Carta Orientativa ao Usuário do Recurso Hídrico Subterrâneo é a síntese das demais cartas expostas acima, destacando-se as potencialidades e fragilidades do recurso, e contém as informações de reserva e consumo, bem como as recomendações ou critérios para uma exploração racional do recurso.

Em termos de método de estudo, a análise integrada das diversas áreas do conhecimento (no caso a integração dos estudos geológicos, geomorfológicos/ pedológicos e climatológicos, como também a evolução sócio-econômica) contribuiu sobremaneira ao maior entendimento da hidrogeologia da área de estudo e da situação atual desse recurso hídrico. Na definição das unidades delimitadas nas cartas de planejamento e meio ambiente, esse tipo de análise fundamentou tecnicamente as compartimentações definidas nas cartas de análise, de aptidões e na carta orientativa.

Em suma, esse trabalho cumpriu com os objetivos propostos, pois contribui ao maior conhecimento da hidrogeologia na Região Metropolitana de Campinas, com a avaliação de seu comportamento hidrodinâmico como também definindo seu potencial. Esse diagnóstico forneceu uma perspectiva de explotação e uso, subsidiando os estudos de planejamento e meio ambiente, bem como indicativos a uma exploração mais racional do recurso. 


\section{BIBLIOGRAFIA}

ASTLE, W. L.; WEBSTER, R.; LAWRANCE, C. .J. 1969. Land classification for management planning in the Luangwa Valley of Zambia. Journ. Appl: Ecol. 6: 143169.1969.

BAKHIREVA, L.V.; LISELEVA, E. A.; LUSHNIKOVA, N. P.; SAVICH, A. A., RODINA,E. E. 1994. Geo-ecological investigations in the area of Comune de Grosio (Northern Italy). Bull. Intern. Assoc. of Enginn. Geology. 49: 15-23. 1994.

BASEI, M.A.S.; CAMPOS NETO, M.C.; BERGMANN, M.; FIGUEIREDO, M.C.H. 1986. Geologia da Folha Amparo, 1:50.000. Rel. Pró-Minério/USP. inédito. 109 pp.

BERTACHINI, A.C. 1987. Estudo das características hidrológicas dos terrenos cristalinos sob clima úmido, na região de Jundiaí, em São Paulo. São Paulo. (Dissertação de Mestrado (Gc-USP). 120 pp.

BORNIER, A., JACKOU, K. \& KARBO, A. 1991. SIGNER - Système d'information géographique du Ministère de I'hydraulique de la Republique du Niger. Hydrogéologie. 1991: (1), pp. 25-34.

BOURGEOIS, M. 1981. Cartes de planification des ressources en eau de Côte-d'Ivoire, du Ghana, du Togo, du Béssin et du Cameroun. Bull. BRGM. (2) III, pp. 389 - 379.

BRANCO, P.C.; VINHA, C.A.G.da \& SOARES FILHO, A.R. 1995. Sistema de informações geográficas para avaliação e gestão de informações hidrogeológicas. $A$ Água em Revista. CPRM. Ano III, 1995. n² 4, pp.: 48-55.

CAMARGO, A. P. 1960. O balanço hídrico no estado de São Paulo. Bol. Instituto Agronômico do Estado de São Paulo, $\mathrm{n}^{0}$ 161. (Tese de Doutoramento - ESALQ). 53pp.

CAMARGO, A.P. de \& GHIZZI, S.M. 1991. Estimativa de temperaturas médias mensais com base em cartas de temperatura potencial normal ao nivel do mar para a região sudeste do Brasil. Inst. Agron. Campinas. Bol. Técn. $\mathrm{n}^{\circ} 141.17$ pp.

CAMPOS NETO, M.C.; BASEI, M.A.S.; ALVES, F.R.; FIGUEIREDO, M.C.H. 1984. Geologia da Folha de Bragança Paulista. 1:50.000. Rel. Pró-Minério/USP. Inédito. $162 \mathrm{pp}$. 
CAMPOS, H.C.N. 1993. Caracterização e cartografia das Províncias Hidrogeoquímicas do Estado de São Paulo. São Paulo, SP. (Tese de Doutoramento - IGc/USP, inédita). $177 \mathrm{p}$.

CAVALCANTE, I.N. 1990. Estudos hidrogeológicos de terreno cristalino com manto de intemperismo - área piloto de Atibaia (SP). (Dissertação de Mestrado IGc-USP). 123 pp.

CELLÍGOI, A. 1993. Recursos hídricos subterrâneos da Formação Serra Geral em Londrina - PR. (Dissertação de Mestrado IGc-USP). 83 pp.

CHERNET, T. 1992. A hydrogeological map of Ethiopia (scale 1:2,000,000). Hydrogeologie, $n^{0 .} 1$-2. 1992. pp.29- 35.

COLLIN, J.J. 1991. Renouveau de la cartographie hydrogéologique. La rencontre des concepts et des outils. Hydrogeologie. $n^{\circ} 1$. 1991. pp. 3-6.

COMITETUL DE STAT AL GEOLOGIEI. INSTITUTUL GEOLOGIC. 1956. Harta Hidrogeologicã 1:100.000 - Bucuresti. Republica Socialistã Romãnia. 44a.

COMPANHIA DE PESQUISA DE RECURSOS MINERAIS (CPRM). 1974. Projeto Sudeste do Estado de São Paulo. Mapa Geológico. Folha SF 23-Y-C. Escala 1:250.000. 1 mapa.

COMPANHIA DE PESQUISA DE RECURSOS MINERAIS (CPRM). 1994. Mapa hidrogeológico de Santa Maria - 1:100.000, Programa Levantamentos Geológicos Básicos do Brasil. Projeto Mapas de Previsão de Recursos Hídricos Subterrâneos. 1 mapa.

COMPANHIA DE PESQUISA DE RECURSOS MINERAIS (CPRM). 1994. Projeto Curitiba - Folha Curitiba - 1:100.000. Programa Informações para Gestão Territorial (GATE). Relatório Técnico CPRM. 5 v.

COTTAS, L.R. 1983. Estudos Geológico-Geotécnicos Aplicados ao Planejamento Urbano de Rio Claro - SP. (Tese de Doutoramento IGc - USP). 171 p.

DAVIS, D. K. 1989. Groundwater resources of Pike County, Pennsilvania. Water Resources Report 65. 1989. Pennsilvania Geological Survey, Fourth Series. Harrisburg. 1989. 63p. 
DE MOOR, G.; DE BREUCK, W. 1976. Preparation of semi-detailed lithologic and hydrogeologic maps for land management by means of a geo-electrical survey. Bull. Intern. Assoc. of Enginn. Geology. 14: 137-140. 1976.

DEARMAN, W. R. \& MATULA, M. 1976. Environmental aspects of engineering geological mapping. Bull. Intern. Assoc. of Enginn. Geology. 14: 141-146. 1976.

DEARMAN, W. R.; MONEY, M.S.; STRACHAN, A. D.; COFFEY, J. R.; MARSDEN, A. 1979. A regional engineering geological map of the Tyne and Wear County, N.E. England. Bull. Intern. Assoc. of Enginn. Geology. 19: 5-17. 1979.

DEPARTAMENTO DE ÁGUAS E ENEGIA ELÉTRICA (DAEE); INSTITUTO DE GEOCIÊNCIAS E CIÊNCIAS EXATAS DO CAMPUS DA UNIVERSIDADE DE RIO CLARO (IGCE-UNESP). 1982. Mapa Geológico do Estado de Sâo Paulo. Folha Campinas. Escala 1:250.000. 1 mapa.

DEPARTAMENTO DE ÁGUAS E ENERGIA ELÉTRICA (DAEE). 1974. Estudo de águas subterrâneas, Região Administrativa 6, Ribeirão Preto, SP. São Paulo, SP. Geopesquisadora/ Tahal, 2v.

DEPARTAMENTO DE ÁGUAS E ENERGIA ELÉTRICA (DAEE). 1975. Estudo de águas subterrâneas, Região Administrativa 1, São Paulo, SP. São Paulo, SP. ENCIBRA Tahal, 3v.

DEPARTAMENTO DE ÁGUAS E ENERGIA ELÉTRICA (DAEE). 1976. Estudo de águas subterrâneas, Regiões Administrativas 7, 8 e 9 (Bauru, São José do Rio Preto, Araçatuba), SP. São Paulo, SP. ENCO, 4v.

DEPARTAMENTO DE ÁGUAS E ENERGIA ELÉTRICA (DAEE). 1977. Estudo de águas subterrâneas, Região Administrativa 3 (São José dos Campos e Faixa Litorânea), $S P$. São Paulo, SP. ENCO, $5 \mathrm{v}$.

DEPARTAMENTO DE ÁGUAS E ENERGIA ELÉTRICA (DAEE). 1979a. Estudo de águas subterrâneas, Região Administrativa 2 (Santos), SP. São Paulo, SP. ENCO, 3v.

DEPARTAMENTO DE ÁGUAS E ENERGIA ELÉTRICA (DAEE). 1979b. Estudo de águas subterrâneas, Regiões Administrativas 10 e 11(Presidente Prudente e Marilia), SP. São Paulo, SP. DAEE, 3v. 
DEPARTAMENTO DE ÁGUAS E ENERGIA ELÉTRICA (DAEE). 1981a. Estudo de águas subterrâneas, Região Administrativa 5 (Campinas), SP. São Paulo, SP. DAEE, $2 \mathrm{v}$.

DEPARTAMENTO DE ÁGUAS E ENERGIA ELÉTRICA (DAEE). 1981b. Estudo de águas subterrâneas, Região Administrativa 4 (Sorocaba), SP. São Paulo, SP..DAEE, 2v.

DEPARTAMENTO DE ÁGUAS E ENERGIA ELÉTRICA (DAEE). no prelo. Carta hidrogeológica do Estado de São Paulo (1:500.000). São Paulo.

DINIZ̈, H.N. 1990. Estudo hidrogeológico do Subgrupo Itararé no médio rio Tietê, municipio de Tietê, SP. (Dissertação de Mestrado IGc-USP). 118 pp.

DINIZ, H.N. 1996. Estudo do potencial hidrogeológico da bacia hidrográfica do rio Baquirivu-Guaçu, municipio de Guarulhos e Arujá, SP. (Tese de Doutoramento IGcUSP). $300 \mathrm{pp}$.

DIOGO, A.; BERTACHINI, A.C.; CAMPOS, H.C.N.S.; ROSA, R.B.G.S. 1984. Estudo preliminar das características hidráulicas e hidroquímicas do Grupo Tubarão no Estado de São Paulo. In: Simp. Reg. Geol., $3^{\circ}$., Atas... São Paulo. SP. SBG/SP. p: 359-364.

DUARTE, U. 1980. Geologia Ambiental da Área de São Pedro - SP - Vetor Águas Subterrâneas. (Tese de Doutoramento IGc - USP). $73 \mathrm{p}$.

EMPLASA. 1993. Cenário Regional, Região de Campinas, Área de Metropolização Aspectos Físico-Ambientais e Sociais. Relat. Técn. EMPLASA.v.1. 199 pp.

FARIAS, I.C. (coordenador). 1994. Guia para la elaboración de estudios del médio fisico: contenido y metodologia. 2a. ed. Min. Obras Publ. y Urb. Centro de Estudios de Ordenácion del Territorio y Medio Ambiente. Madrid. Espanha. (Serie Manuales, 3). $572 p$.

FERNANDEZ, J.A.; DEL MORA, J. \& PEÑA PINTO, J.L. 1979. Spanish experience of geotechnical cartography in an urban area. Bull. Intern. Assoc.of Enginn. Geology. 19: 79-84. 1979.

FERRO, B. P. A. \& BOUMAN, D. 1992. The hydrogeological map of Moçambique (scale 1:1,000,000). Hydrogeologie. $n^{0 .} 1$ - 2. 1992. pp.17 -27. 
FOSTER, S.S.D. \& HIRATA, R.C.A. 1991. Determinación del riesgo de contaminación de aguas subterranéas. Una metodologia basada em datos existentes. CEPIS, OPS/OMS, $2^{a}$ edición. Lima, Peru.

FRIED, J.-J. 1992. Le seminaire ministeriel sur la gestion et la protction des eaux souterraines. La Haye, 26 et 27 novembre 1991. Hydrogeologie. $n^{\circ} 4$. 1992. pp. 131132.

FUNARI, F.L. 1984. Insolação, Radiação Solar global e Radiação Liquido no Brasil. (Dissertação de Mestrado FFLCH-USP).

GEOLOGICAL SURVEY OF CANADA. 1967. Groundwater in Canada. Economic Geology Report n'. 24. 228 p. Canada. 1967.

GIUSTI, D.A. 1989. Contribuição à Geologia Ambiental no Município de Curitiba - PR. (Dissertação de Mestrado IGc - USP). $115 \mathrm{p}$.

GOLODSKAYA, G. A. 1979.Enginnering geological mapping in conjunction with protection of the geological environment. Bull. Intern. Assoc. of Enginn. Geology. 19: 348-350. 1979.

GONÇALVES, A.R.L. 1986. Geologia Ambiental da Área de São Carlos. (Tese de Doutoramento (Gc-USP). $138 \mathrm{p}$.

GOURGAND, B.; STILELTJES, L. \& DAESSLÉ, M. 1988. lle de la Réunion: explotation des eaux souterraines. Bilan des prélèvements effectués en 1985 par puits et forages. Hydrogeologie. $n^{\circ}$ 2. 1988. pp. 117-123.

GROUNDWATER - HIDROGEOLOGIA E ENGENHARIA S/C LTDA. 1984. Estudo de avaliação de recursos hídricos subterrâneos no Municipio de Sumaré - SP. Relatório Técnico GW-105/84. 2v.

GUTJAHR, M.R. 1993. Critérios relacionados a compartimentação climática de bacias hidrográficas: a bacia do rio Ribeira de Iguape - SP. (Dissertação de Mestrado IGEOG-USP).

HIRATA, R.C.A. 1994. Fundamentos e estratégias de proteção e controle da qualidade das águas subterrâneas. Estudos de casos no estado de São Paulo. (Tese de Doutoramento (Gc-USP). $210 \mathrm{pp}$. 
HOFMANN, G. W. 1976. Mapping for urban land-use planning in southeast Queensland A first approach. Bull. Intern. Assoc. of Enginn. Geology. 14: 113-117. 1976.

INSTITUTO DE PESQUISAS TECNOLÓGICAS (IPT). 1989. Compartimentação Estrutural e Evolução Tectõnica do Estado de São Paulo. SCTDE/PRÓ-MINÉRIO. 2 v.

INSTITUTO DE PESQUISAS TECNOLÓGICAS (IPT). 1981. Mapa Geológico do Estado de São Paulo. SICCT-PROMINÉRIO/IPT. Escala 1:500.000.

INSTITUTO GEOGRÁFICO E CARTOGRÁFICO (IGC). 1993. Expressão Regional Campinas. Atlas. São Paulo. IGC. Secr. Plan. Gestão/CPR/IGC. 24p.

INSTITUTO GEOLÓGICO (IG-SMA). 1990a. Avaliação dos recursos hídricos subterrâneos: ocorrência e explotação. Folha de Salto de Pirapora, SP, escala 1:50.000. Relatório Técnico IG. 96 pp.

INSTITUTO GEOLÓGICO (IG-SMA). 1990b. Subsídios do meio físico-geológico ao planejamento do município de Sorocaba (SP). Relatório Técnico IG. 2v.

INSTITUTO GEOLÓGICO (IG-SMA). 1991. Subsídios do meio físico-geológico ao planejamento do municipio de Itu (SP). Relatório Técnico IG. $2 \mathrm{v}$.

INSTITUTO GEOLÓGICO (IG-SMA). 1993. Subsidios do meio físico-geológico ao planejamento do município de Campinas (SP). Relatório Técnico IG. 3v.

INSTITUTO GEOLÓGICO (IG-SMA). 1995. Subsidios para o planejamento regional e urbano do meio físico na porção média da Bacia do Rio Piracicaba, SP. São Paulo. Relatório Técnico IG. 4 v.

INSTITUTO GEOLÓGICO (IG-SMA) / COMPANHIA DE TECNOLOGIA DE SANEAMENTO AMBIENTAL (CETESB)/ DEPARTAMENTO DE ÁGUAS E ENERGIA ELÉTRICA (DAEE). 1993. Mapeamento da vulnerabilidade e risco de poluição das águas subterrâneas no estado de São Paulo. Relatório Técnico IG. $2 \mathrm{v}$.

IRITANI, M.A. 1993. Potencial hidrogeológico da Cidade Universitária de São Paulo. (Dissertação de Mestrado IGc-USP). 97 pp.

JOHNSON, K. S. \& LUZA, K. V. 1981. Preparation of regional maps showing natural and man-made geologic hazards. Bull. Intern. Assoc. of Enginn. Geology. 23: 15-19. 1981. 
LANDRY, J. 1979. Recherche de sites favorables a l'implantation d'une ville nouvelle dans la region de Jizan (Arabie Saoudite). 1979. Bull. Intern. Assoc.of Enginn. Geology. 19: 57-61. 1979.

LLAMAS, M.R. 1992. La surexplotation des aquiferes; aspects techniques et institutionnels. Hydrogeologie. $n^{\circ}$ 4. 1992. pp. 139-144.

LOPES, M.F.C. 1984. Água subterrânea no Estado de São Paulo - Síntese das condições de ocorrência. In: Congres. Bras. Águas Subter., 3, Anais...ABAS. Fortaleza. v 2, pp 305-317.

LOPES, M.F.C. 1994. Condições de ocorrência de água subterrânea nas bacias dos rios Piracicaba e Capivari. (Dissertação de Mestrado Fac. Eng. Civil - UNICAMP). 83 pp.

LOZINSKA-STEPIEN, H. 1979. Enginnering geological maps at a scale 1:25.000 for regional planning purposes. Bull. Intern. Assoc. of Enginn. Geology. 19: 69-72. 1979.

MABBUTT, J.A. \& STEWART, G.A. 1963. The Application of Geomorphology in Resources Surveys in Australia and New Guinea. Revue de Geomorphologie dynamique. XIV Année, nos 7-8-9: 97-109.

MACIEL FILHO, C.L. 1990. Carta Geotécnica de Santa Maria. Publ. Avulsa. Univ. Fed. Santa Maria. 21p.

MARGAT, J. 1981. La carte hydrogéologique de la France à 1:500.000. Bull. BRGM. (2), III, pp. 98-99.

MARGAT, J. 1992. Quel est le concept du surexplotation utile à la gestion des eaux souterraines? Hydrogeologie. $n^{\circ} 4$. 1992. pp. 145-152.

MARTINELLI, M. 1994. Cartografia ambiental: uma cartografia diferente? Rev. Depto. de Geografia. FFLCH-USP. 7:61-80.

MATHESON, C. C. \& FONT, R. G. 1974. Geologic environment: forgotten aspect in the land use planning process. Geologic Enviroment. $23-28$.

MATULA, M. 1979. Regional engineering geological evaluation for planning purposes. Bull. Intern. Assoc. of Enginn. Geology. 19: 18-24. 1979.

MCELROY, T. A. 1988. Groundwater resources of Fayette County, Pennsilvania. Water Resources Report 60. Pennsilvania Geological Survey, Fourth Series. Harrisburg. 1988. 57p. 
MEISTER, H. \& BECHER, A. 1971. Hydrogeology of the carbonate rocks of the Lancaster 15-minute quadrangle, Southearsten Pennsylvania. Groundwater Report. Harrisburg. W26. $149 \mathrm{p}$.

MELNIKOV, E. S. 1979. The main principles of procedure for the national engineering geological survey in the URSS. Bull. Intern. Assoc.of Enginn. Geology. 19: 93-95. 1979.

MENEGASSE, L.N. \& DUARTE, U. 1990. Locação de poços profundos nos terrenos metamórficos e cristalinos a NW da Grande São Paulo. In: CONG. BRAS. ÁGUAS SUBT., Anais... Porto Alegre, ABAS. P. 190-198.

MERLA, A.; MERLO, C. \& OLIVERI, F. 1976. Detailed engineering-geological mapping in select italian mountainous areas: methodology and examples. Bull. Intern. Assoc.of Enginn. Geology. 14: 129-135. 1976.

MONTEIRO, C.A. de F. 1973. A dinâmica climática e as chuvas do estado de São Paulo. Estudo em forma de Atlas. São Paulo, IGEOG-USP.

MONTEIRO, C.A. de F. 1976. Teoria e clima urbano. Série Teses \& Monografias IGEOGUSP, 25pp.

MUÑOZ, S. \& LANGEVIN, C. 1991. Adaptation d'une méthode cartographique assistée à l'élaboration de cartes de vulnérabilité au Guatemala. Hydrogeologie. $n^{\circ} 1.1991$. pp. 65-84.

NISHIMURA, L. \& ZUQUETTE, L.V. 1994. A importância da cartografia geotécnica para caracterização de áreas de vulnerabilidade de aqüíferos livres: Exemplo do Aqüífero Botucatu na Quadrícula de São Carlos, SP. Geociências. v.13(2): 345-357, 1994.

ORGANIZAÇÃO DOS ESTADOS AMERICANOS (OEA). 1971. Bacia do Rio do Prata: Estudo para sua Planificação e Desenvolvimento. Secr. Geral Org. Est. Amer. Washington. 1971. 4V.

ORLANDINO FILHO, V. \& GIUGNO, N.B. 1993. Cartas temáticas multidisciplinares da Bacia do Rio Gravataí, RS. In: Forum Nacional sobre Geologia de Meios Urbanos, I, Anais...UFRS/ALERS/APSBG. Porto Alegre. RS. pp. 25-30. 
OUDE MUNNINK, J.M.E. \& GEIRNAERT, W. 1991. GIS assisted design of a monitoring network for non-point groundwater pollution in the province of North-Holland, the Netherlands. Hydrogeologie. $n^{\circ}$ 1. 1991. pp. 91-104.

PARISOT, E.H. 1983. As águas subterrâneas no centro-oeste do município de São Paulo. Características hidrogeológicas e químicas. (Dissertação de Mestrado IGCUSP). 93 pp.

'PERDO Jr, M.J.; MELLO, M.H.A.; ORTOLANI, A.A.; ALFONSI, R.R.; SENTELHAS, P.C. 1991. Estimativas das temperaturas médias mensais das máximas e das mínimas para o estado de São Paulo. Inst. Agron. Campinas. Bol. Tecn. n ${ }^{\circ} 142.11 \mathrm{pp}$.

PEVERIERI, G.; FICO, L.; SUPPO, M.; CREMA, G. 1991. Utilization of a geographic information system study, conservation and management of ground water resources in the Ofanto river (Italy). Hydrogeologie. $n^{\circ} 1$ 1991. pp. 11-23.

PIRES NETO, A.G. 1994. Planejarnento Territorial. A Abordagem Geológico-Geotécnica e o Conceito de Terreno ou a Abordagem da Paisagem. Rev. Depart. Geografia (FFLCH - USP) (7) 8: 51-62.

PIRES NETO, A.G. 1996. Estudo Morfotectônico das Bacias Hidrográficas dos Rios Piracicaba, Capivari, Jundiaí e Áreas adjacentes no Planalto Atlântico e Depressão Periférica. Proj. CNPq 150011/94-6, realizado em IGCE-UNESP . Rio Claro. 71 pp.

PIRES NETO, A.G. mim. Relações Taxonómicas dos Componentes e Atributos do Meio Físico.

PIRES NETO, A.G.; BROLLO, M.J. \& YOSHINAGA, S. 1995. El desarrollo de estudios geoambientales para la planificación territorial en el Instituto Geológico São Paulo Brasil. In: Curso Internacional sobre microzonificacion y su aplicacion at planeamiento urbano para la mitigacion de desastres, VII. Anales...UNI/FIC/JICA. Lima. Perú.

PRADO, J. L.; PEÑA PINTO, J.L. 1979. Problems involved in the preparation of geothecnical maps at a scale of 1:25.000.Bull. Intern. Assoc.of Enginn. Geology. 19: 84-87. 1979.

RADBRUCH-HALL., D. H. 1979. Environmental aspects of engineering geological mapping in the United States. Bull. Intern. Assoc. of Enginn. Geology. 19: 351-358. 1979. 
REBOUÇAS, A.C. 1976. Recursos hídricos subterrâneos da Bacia do Paraná. Análise de pré-viabilidade. (Tese de Livre Docência IGc-USP). 145 pp.

REBOUÇAS, A.C. 1980. Aspectos hidrogeológicos no planejamento da ocupação urbana na Grande São Paulo. In: Aspectos geológicos e geotécnicos da Bacia Sedimentar de São Paulo, Mesa Redonda, São Paulo. 1990. Publ. Especial. ABGE/SBG-SP. p. $129-138$.

'ROCKAWAY, J. D. 1976. The influence of map escale on engineering geologic mapping. Bull. Intern. Assoc. of Enginn. Geology. 14: 119-122. 1976.

RÓNAI, A. 1979. Fundamentals of enginnering geological maps. Bull. Intern. Assoc.of Enginn. Geology. 19: 62-68. 1979.

SANEJOUAND, R. 1972. La cartographie geotechnique en France - Laboratoire Central ponts et choussés, Paris.

SAVANÉ, L.; AFFIAN, K.; KOLI BI, Z.; COUGNY, G. 1991. Stratégie de recherche des eaux souterraines dans les régions à substratum cristallin: exemple du departement de Korhogo (Côte d'Ivoire). Bull. Intern. Assoc. of Enginn. Geology. 44: 79-88. 1991.

SEIGNEMARTIN, C.L. 1979. Geologia de Áreas Urbanas: o exemplo de Ribeirão Preto, $S P$. (Tese de Doutoramento IGc - USP). $2 \mathrm{v}$.

SHEPHARD-THORN, E. R. \& MOSELEY, R. 1979. The potential application of regional hydrogeological maps to engineering geology. Bull. Intern. Assoc.of Enginn. Geology. 19: 234-236. 1979.

SILVA, A.B. da. 1984. Análise morfoestrutural, hidrogeológica e hidroquímica no estudo do aqüifero cárstico do Jaíba, norte de Minas Gerais. (Tese de Doutoramento IGcUSP). $190 \mathrm{pp}$.

SILVA, R.B.G. da.1983. Estudo hidroquímico e isotópico das águas subterrâneas do aqüifero Botucatu no estado de São Paulo. (Tese de Doutorado IGc-USP). 133 pp.

SIMONOT, M. \& WALRAEVENS, P. 1991. SIGMA: Un outil de gestion des resources en eau du Mali. Hydrogeologie. 1991 - (1): pp. 35 - 44.

SORRE, M. 1951. Les fundaments de la geographie humaine. Libraire Armand Colin. Paris. 
SOUZA FILHO, E.E. 1986. Mapeamento Faciológico do Subgrupo Itararé na Quadrícula de Campinas. (Dissertação de Mestrado IGc-USP). 121 pp.

SOUZA, N.C.D.C. 1992. Mapeamento Geotécnico Regional da Folha de Aguai: com base na comportimentação por formas de relevo e perfis típicos de alteração. (Dissertação de Mestrado Esc. Eng. São Carlos - USP). 2v.

STEVAUX, J.C.; SOUZA FILHO, E.E.; TEIXEIRA, J.A.; LANDIM, P.M.B. 1987. Sistemas Deposicionais do Subgrupo Itararé $(P-C)$ na Bacia Hidrográfica do Baixo Rio Capivari (SP): um modelo para prospecção de água subterrânea. In: Simp. Reg. de Geol, $6^{\circ}$, Atas...Rio Claro. SP. SBG/SP. v.1, p: 355-364.

STRUCKMEIER, W.F. \& KRAMPE, K. 1992. Developments in hydrogeological mapping. A state-of-the-art report in view of medium scale hydrogeological mapping in Africa. Hydrogeologie. no 1-2. pp. 105-111. 1992.

STRUCKMEIER, W.F. \& MARGAT, J. 1989. Les cartes hydrogeologiques au service du development économique et social. Hydrogeologie, $n^{\circ}$ 4. 1989. pp. 293-296

THORNTHWAITE, C.W. \& MATHER, J.R. 1955. The water balance. Publications in climatology. Centerton. New York. 104 pp.

TRICART, J. 1977. Ecodinâmica. Rio de Janeiro. SUPREN.

UNITED STATES GEOLOGICAL SURVEY (USGS). 1992. Simulation of regional groundwater flow in the Cambrian-Ordovician Aquifer System in the Northern Midwest, United States. USGS Paper 1405-C. 97 pp.

VEDOVELlo, R. 1993. Zoneamento Geotécnico, por Sensoriamento Remoto, para Estudos de Planejamento do Meio Físico - Aplicação em Expansão Urbana. (Dissertação de Mestrado INPE). 58 p.

VLACH, S.R.F. 1993. Geologia e Petrologia dos Granitóides de Morungaba (SP). (Tese de Doutoramento (Gc-USP). Inédita. $414 \mathrm{pp}$.

WAGNER, W.; ZOMENIS, S. L. \& PLÖTHNER, D. 1990. Groundwater quality in the region between Nicosia, Larnaca and Limassol, Cyprus. Geologisches Jahrbuch Reihe C, Heft 54. 56 p. Hannover. 1990. 
WORLD METEOROLOGICAL ORGANIZATION (WMO). 1983. Guide to climatological practices $n^{\circ}$. 100. Secretariat of the World Meteorological Organization. Geneva. Switzerland. $2^{\text {nd }}$. edition.

YOSHINAGA, S. 1990. Estudos hidrogeológicos, hidrogeoquímicos e isotópicos das águas minerais e termais de Águas de Lindóia e Lindóia, SP. (Dissertação de Mestrado (Gc-USP). 124 pp.

' ZONNEVELD, I. 1992. Land evaluation and landscape science. UIMP. mim. 22p.

ZUQUETTE, L.V. \& GANDOLFI, N. 1988. Mapeamento geotécnico: levantamento e análise das metodologias e sistemáticas mais utilizadas. In: Congres. Lat.-Americano Geologia, III. Anais...Belém/PA, SBG. v 1: 591 - 605.

ZUQUETTE, L.V. 1987. Análise crítica da cartografia geotécnica e proposta metodológica para condições brasileiras. (Tese de Doutoramento - E.F.S.C. São Carlos, SP). 3v.

ZUQUETTE, L.V. 1993. Importância do Mapeamento Geotécnico no Uso e Ocupação do Meio Físico: Fundamentos e Guia para Exploração. (Tese de Livre Docência Esc. Eng. São Carlos - USP). 2v.

ZUQUETTE, L.V.; PEJON, O.J.; GANDOLFI, N.; SINELLI, O. 1993. Carta do Potencial de Risco à Contaminação das Águas Subterrâneas e do Potencial Agrícola, Região de Ribeirão Preto, SP, Brasil. Geociências. v. 12(2): 531-540, 1993. 


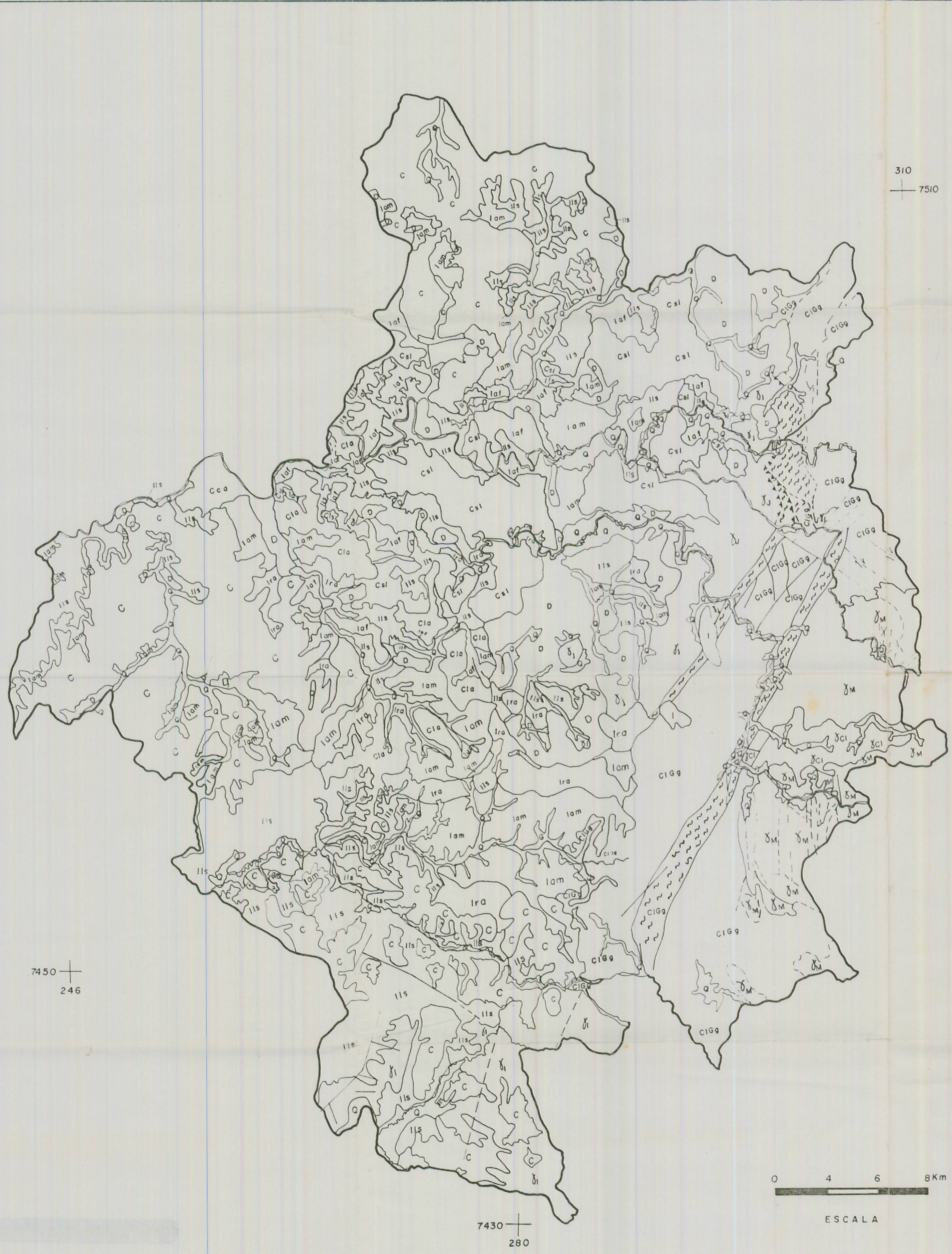

CENozöico

LEGENDA

(1)

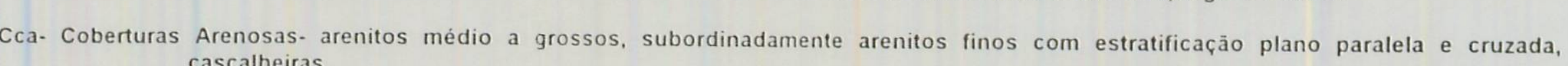

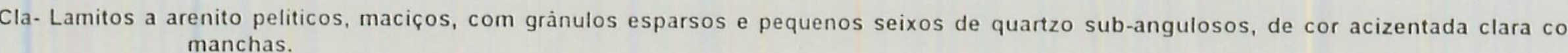

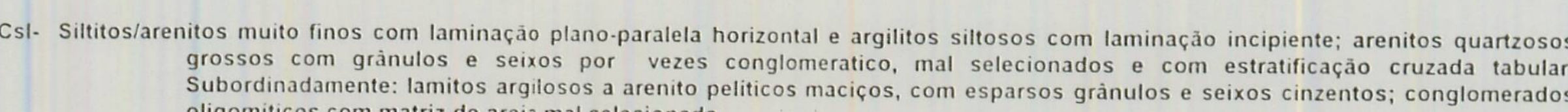

JUROCRE TACEO - FormaGáo SERRA GeRAL

PERMO.CARBONIFERO - SUGGRUPO ITARARE

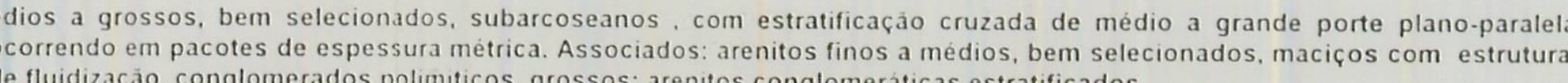
(a)

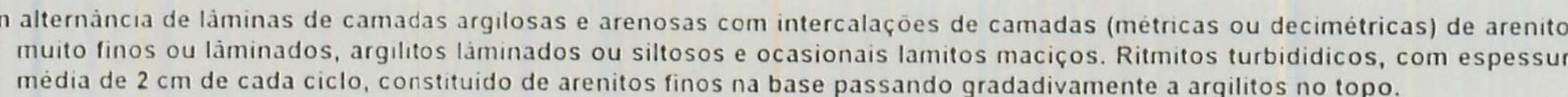

CAMBRIANO - ORDOVIVIANO - GRANIITO ITU

ROTEROZOICO SUPERIOR GRANIO MORUNGABA

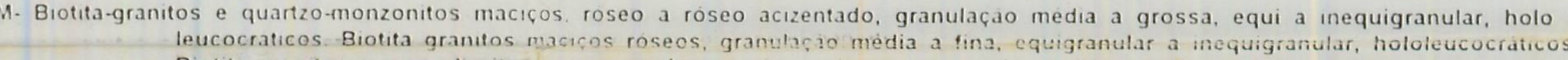

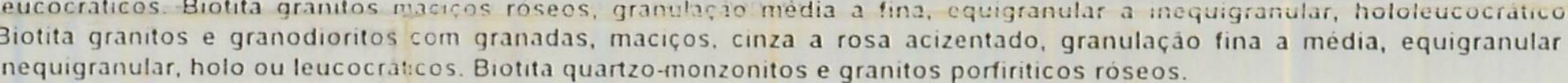
GRAMITIOIE JAGUariún

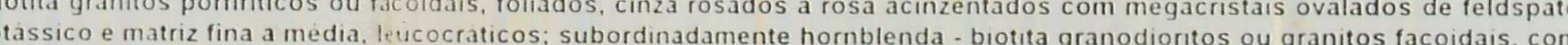

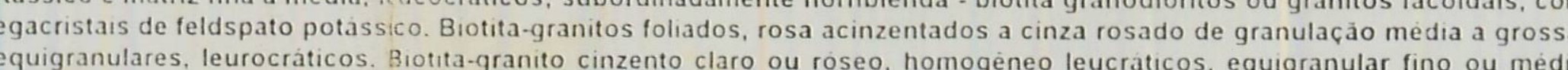

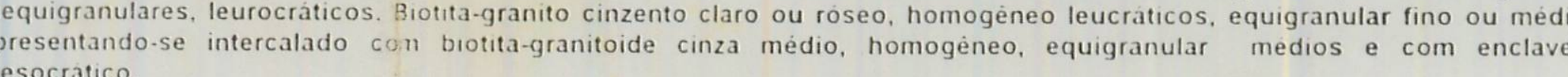

PROTEROZÖICO MÉDO . COMPLEXO ITAPIRA

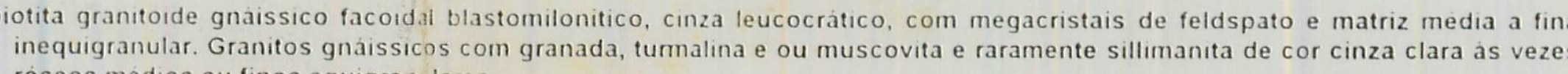

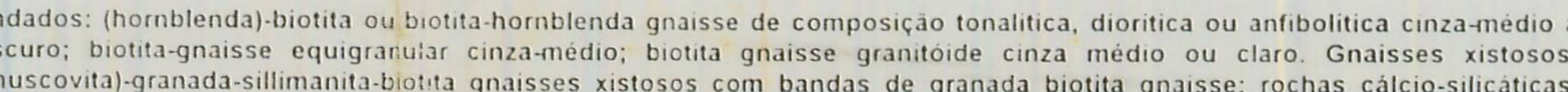

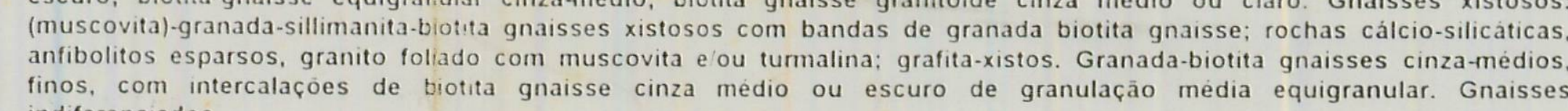

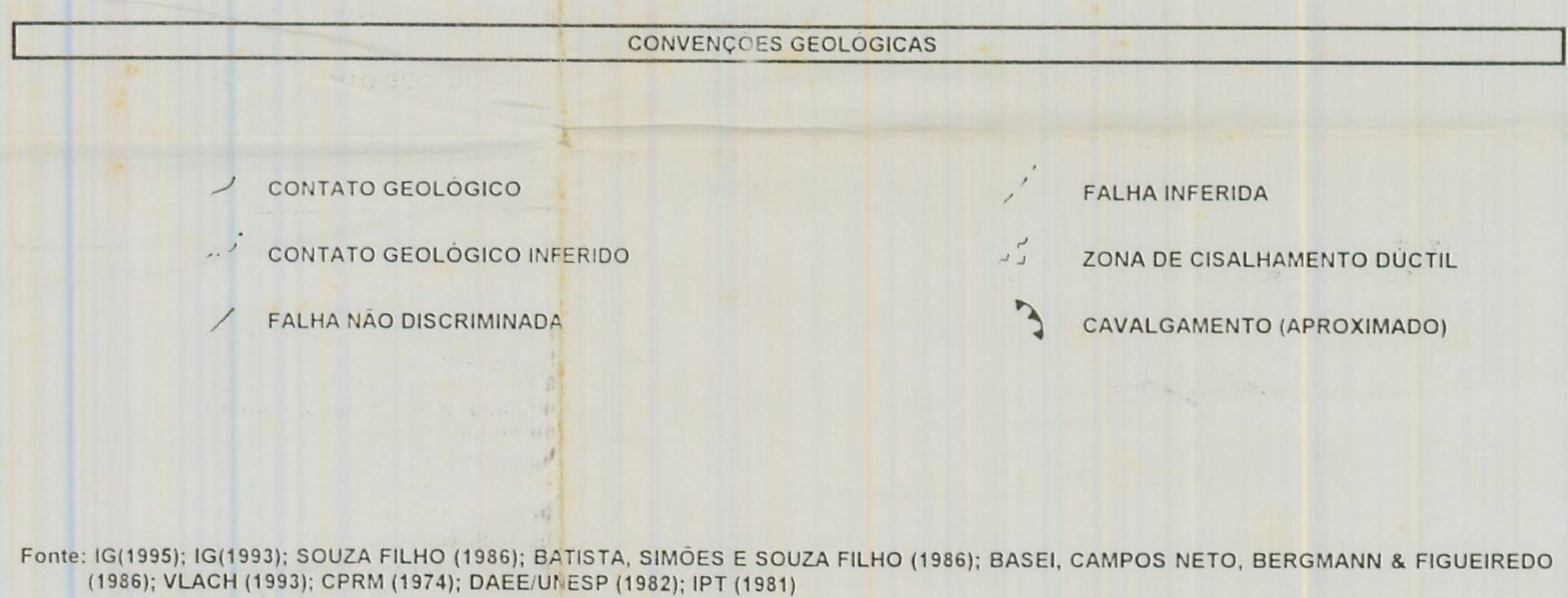

ANEXO 2 - MAPA GEOLÓGICO DA ÁREA DE ESTUDO 


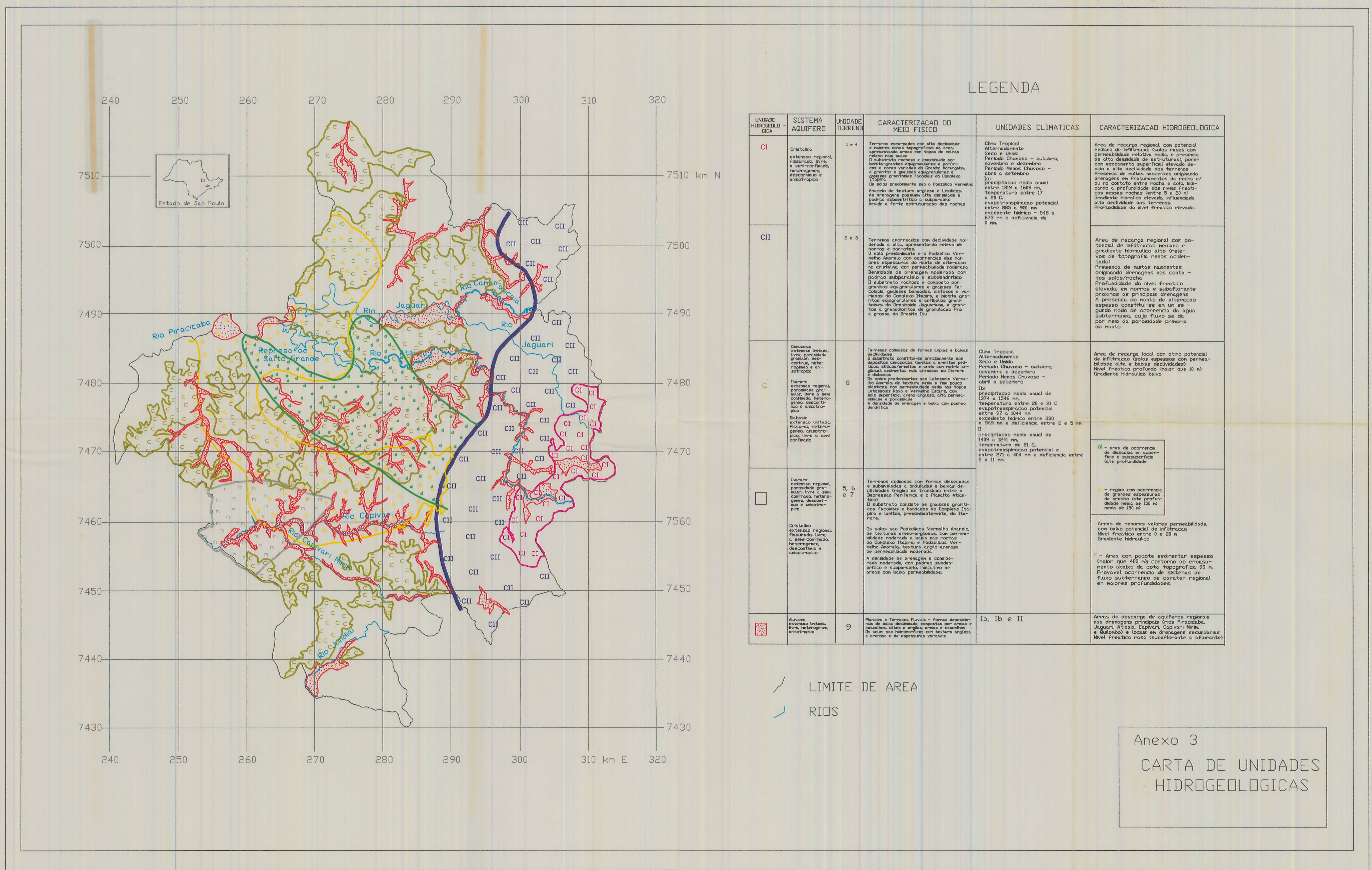




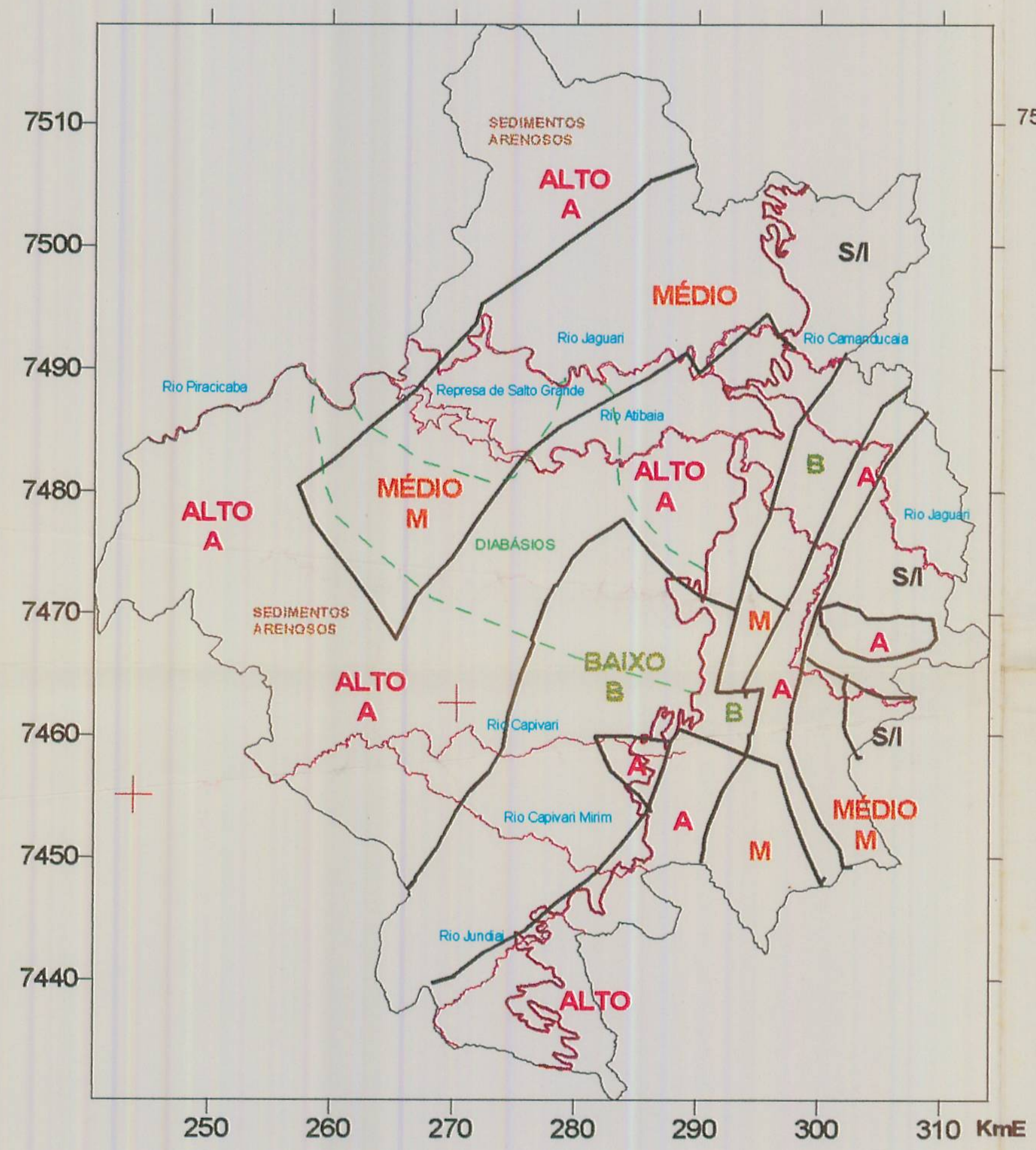

$7510 \mathrm{KmN}$

\section{LEGENDA}

\begin{tabular}{|c|c|c|c|c|c|}
\hline \multirow{2}{*}{$\begin{array}{l}\text { SISTEMAS } \\
\text { AQUIFEROS }\end{array}$} & \multicolumn{3}{|c|}{$\begin{array}{l}\text { PRODUTIVIDADE } \\
(\mathrm{m} 3 \mathrm{~N} / \mathrm{m})\end{array}$} & \multirow{2}{*}{\multicolumn{2}{|c|}{$\begin{array}{l}\text { PRINCIPAIS FATORES CONDICIONANTES } \\
\text { DAPRODUTVIVADE }\end{array}$}} \\
\hline & $\begin{array}{c}\text { ALTA } \\
A\end{array}$ & $\begin{array}{l}\text { MÉDIA } \\
\text { M }\end{array}$ & $\begin{array}{l}B A I X A \\
B\end{array}$ & & \\
\hline TUBARÁO & $0.14 \mathrm{a} 3.86$ & 0.09 a 0.14 & 0,00 e 0.09 & \multirow{3}{*}{ 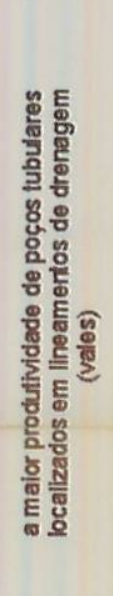 } & 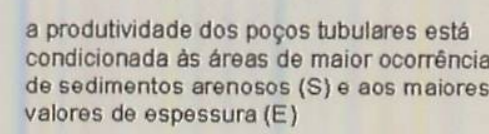 \\
\hline CRISTALINO & $0.13 \& 8.00$ & 0.07 a 0.35 & $0.00 \& 0.07$ & & 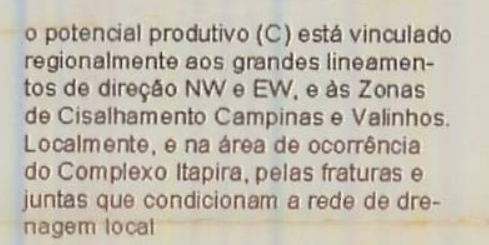 \\
\hline DIABÁSIOS & $0.12 \times 16,61$ & & 0.00 a 0.04 & & 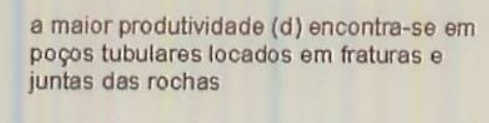 \\
\hline Mistos & $0.10 \Leftrightarrow 0.50$ & $0.04 \times 0.10$ & $0.00 \times 0.04$ & & 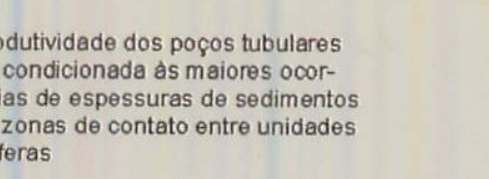 \\
\hline
\end{tabular}

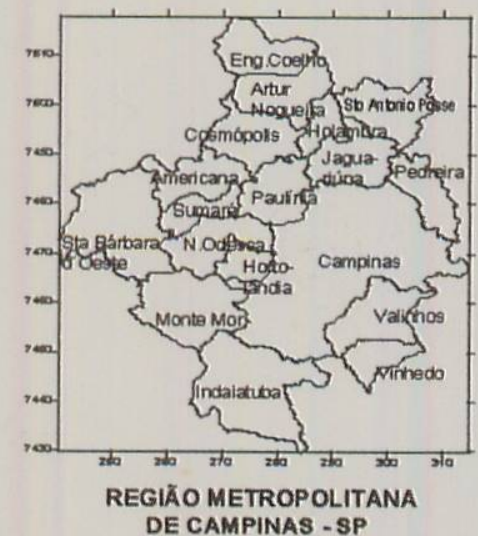

SA - sem informaçăo

Contato entre o embasamento cristalino (a leste) com Subgrupo ltararé (â oeste)

Drenagens principais

\section{ANEXO 4}

CARTA DE PRODUTIVIDADE

ENCIAS - USP 


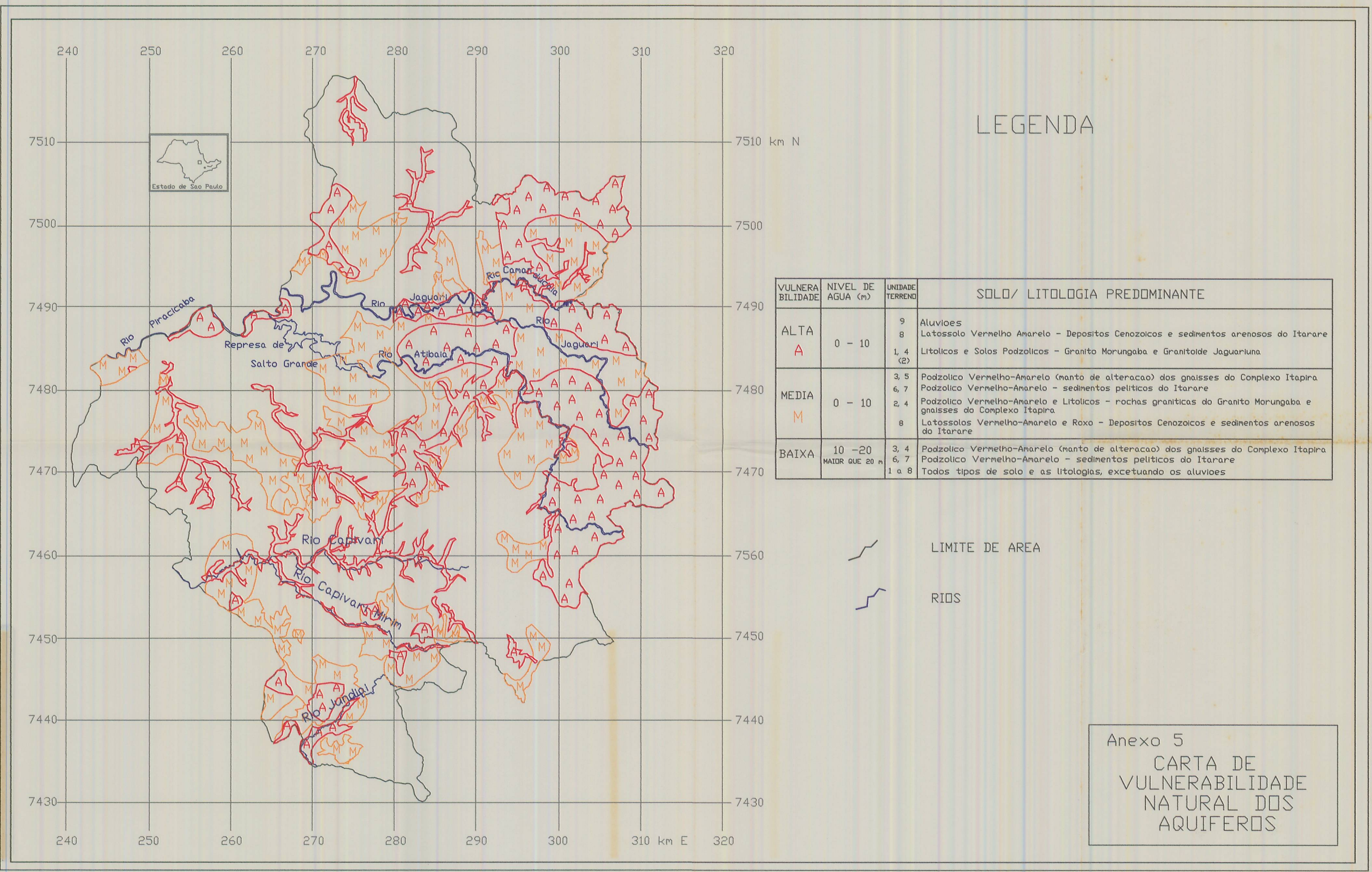




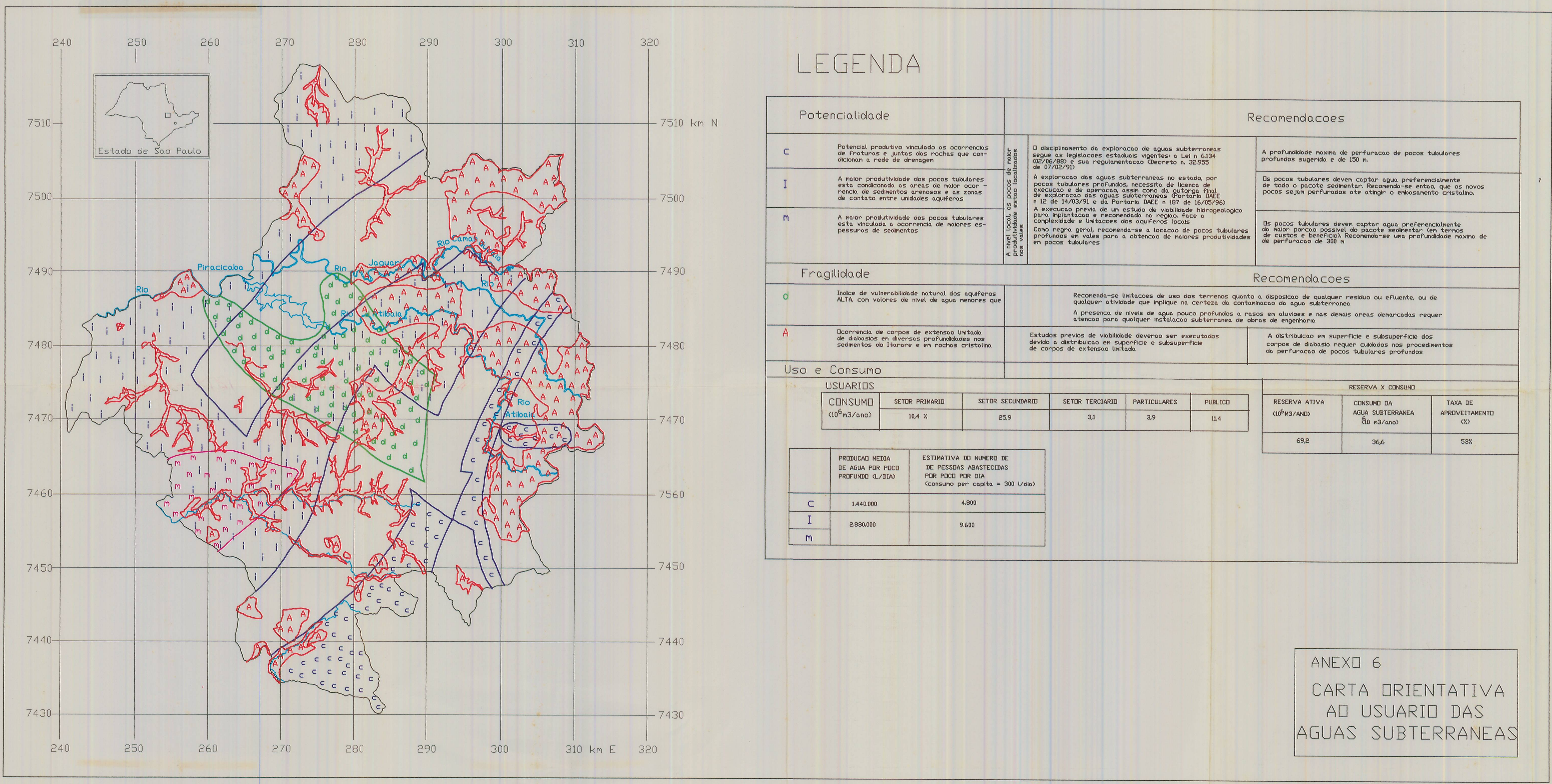

